UNIVERSIDADE ESTADUAL PAULISTA FACULDADE DE CIÊNCIAS E TECNOLOGIA

CAMPUS DE PRESIDENTE PRUDENTE PROGRAMA DE PÓS-GRADUAÇÃO EM GEOGRAFIA

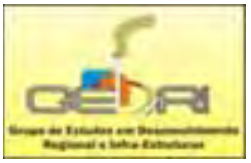

GEDRI - GRUPO DE ESTUDO EM DESENVOLVIMENTO REGIONAL E INFRAESTRUTURA

\author{
ANA PAULA CAMILO PEREIRA
}

\title{
TRANSPORTE AÉREO REGIONAL NO ESTADO DE SÃO PAULO
}




\section{ANA PAULA CAMILO PEREIRA}

\section{TRANSPORTE AÉREO REGIONAL NO ESTADO DE SÃO PAULO}

Dissertação de Mestrado apresentada ao Programa de Pós Graduação em Geografia da Faculdade de Ciências e Tecnologia, FCT-UNESP, Campus de Presidente Prudente/SP, como requisito para obtenção do Título de Mestre em Geografia.

Orientador: Prof. Dr. Márcio Rogério Silveira 
Camilo Pereira, Ana Paula.

C19t Transporte Aéreo Regional no Estado de São Paulo / Ana Paula Camilo Pereira. - Presidente Prudente : [s.n], 2010 xiv, $261 \mathrm{f}$. : il.

Dissertação (mestrado) - Universidade Estadual Paulista, Faculdade de Ciências e Tecnologia

Orientador: Márcio Rogério Silveira

Banca: Everaldo Santos Melazzo, Lisandra Pereira Lamoso

Inclui bibliografia

1. Transporte aéreo. 2. Fluxos. 3. Geografia Econômica. I. Autor. II. Universidade Estadual Paulista. Faculdade de Ciências e Tecnologia. III. Título.

$\operatorname{CDD}$ (18.ed.) 910

Ficha catalográfica elaborada pela Seção Técnica de Aquisição e Tratamento da Informação Serviço Técnico de Biblioteca e Documentação - UNESP, Câmpus de Presidente Prudente. 


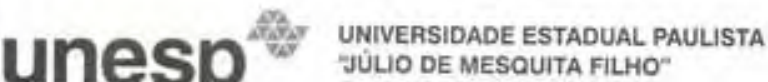 \\ Campis de Presidente Prudento}

\section{BANCA EXAMINADORA}
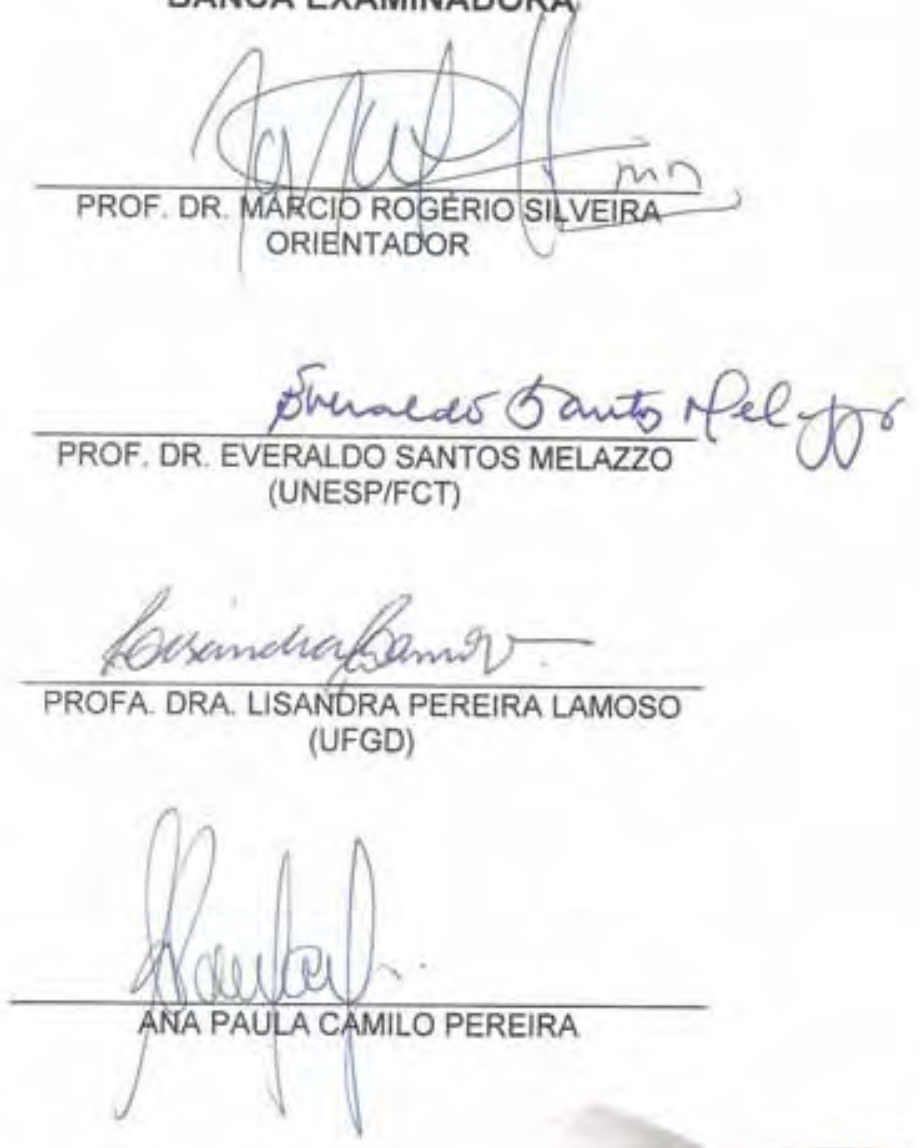

Presidente Prudente (SP), 18 de janeiro de 2010.

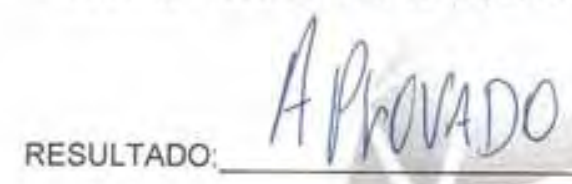

Facuidade de Ciéncias e Tecnologia Seçáo de Pós-Graduaç̧⿸厃㔾

Rua Roberto Simonsen, 305 CEP 19060-900 Presidonte Prudente SP

Tet $18222-5352$ tax $18223-4519$ posgrad Bprudente.unesp.br 


\section{Dedicatória}

Aos meus pais, Samuel Pereira e Eliana Camilo, pelo apoio, incentivo e pelo imenso esforço realizado para que eu continuasse estudando. Por acreditarem em meus sonhos e viverem intensamente mais esta etapa da minha vida.

Ao meu avô José Ramalho Camilo... Saudades daquele tempo em que procurar palitinhos de sorvete era a coisa mais importante do nosso dia!!! 


\section{Agradecimentos}

Inquestionavelmente esse é o melhor momento, agradecer a cada um(a) que fez parte dessa trajetória.

Para mim, é impossível iniciar essas páginas sem agradecer a Deus, que me concede vida e saúde e que tem me ensinado o caminho dia a dia.

A minha familia que foi mais que meu refúgio, foi meu conforto, foi para onde fugi, mas foi também onde encontrei prazer para voltar.

Minha Mãe Eliana, minha amiga, confidente, em quem me encontro e quem me encontra. É quem me sente no som da minha voz, é quem me faz compreender o que às vezes não consigo

aceitar.

Meu Pai Samuel, que na sua simplicidade me ensina a ver o valor das pessoas. Sua garra, seu caráter e sua inteligência mostram-me, cotidianamente, que eu posso vencer, sempre que eu quiser, simples assim...

Ao Jaime, que é quem mais sente meus humores, primeiro, porque nasci ontem e ele amanhã; segundo, porque quero tudo para anteontem e ele para depois de amanhã. Agradeço pela grande ajuda na cartografia desse trabalho, por me tirar da rotina e me fazer rir e por me ensinar que a vida tem seu tempo e que as pessoas o têm ainda mais.

A minha princesa Eduarda, que torna meus dias mais alegres. Acordar com seus beijos e escutar você dizer: tia Póla, enchem meus olhos e meu coração. Você para mim é muito mais que meu "Alecrim Dourado".

Ao meu irmão Junior e a minha cunhada Evelin.

A mais nova alegria de nossa casa, Maria Fernanda, que fala com seu sorriso e encanta com suas conversas. Uma dádiva...

Aos meus primos: Rick, Hety, Dani, Manu e Daiane. As minhas tias Sirlei e Dayaninha e a minha avó Ditinha.

Ao S. Jaime, D. Nalva e Bruno, por sempre me receberem em sua casa com muito carinho.

Ao Professor Márcio, com quem aprendi que a qualidade do nosso trabalho está na dedicação e na seriedade com que o fazemos. Agradeço pelo apoio, pelo incentivo e por acreditar que eu sempre posso mais...

Aos meus amigos de Assis/SP, de Dourados/MS, de Presidente Prudente/SP e de Ourinhos/SP: A uma amizade alegre e descontraída: Valéria, Solange, Adriano Helfenstein e Jaime (pelas bagunças, risadas, viagens, conversas e caipirinhas...) Pela convivência durante estes anos prudentinos: Nelson, Nildo, Adriano Amaro, Elaine Cícero e Natália. As amizades que estão na lembrança: Eduardo Loss, Ângelo, Lígia, Naman e Cavanha. 
A Val (Bixona), amiga de todas as horas, que sempre procura me fazer ver o lado bom de tudo e de todos, mesmo quando não existem.

A Sol (Brancona) pela imensa ajuda nos inexplicáveis meses que morei em Nova Andradina/MS e, claro, agradeço, também ao S. Chico e a Elizete. Ao pessoal do GEDRI, pelas reuniões, pelas discussões e pela amizade. Aos meninos, como sempre os chamo: Nelson, Nildo, Emmanuel, Airton, Rodrigo e Renan.

A Raquel pelas acolhidas em Ourinhos/SP, que nossas conversas madrugada a fora, as risadas e desabafos permaneçam.

A Natália, alegria que transcende, pela sua amizade alegre, livre e leve. A Elaine, que me acolheu em Presidente Prudente/SP e escutou-me nos momentos de maior aflição e descontentamento, que me encorajou indiferente das minhas escolhas. Ao Adriano Amaro, sempre pronto a ajudar, pela sua amizade solidária. Ao Nelsinho, pela sua atenção, ajuda e compreensão.

A Bruna Santos que me abrigou nos primeiros meses em Presidente Prudente/SP. A Camila... pelas risadas, fofocas e claro pelas aulas de francês, e as vezes de inglês e português, pela paciência de escutar meu sofrivel franguês.

Aos professores da UFGD, em especial a Lisandra, professora e orientadora que me incentivou, aconselhou e ajudou nas escolhas mais difíceis.

Aos alunos da Pós-Graduação da Unesp/FCT com os quais compartilhei alegrias, angústias, decepções e conversas.

Aos professores da Pós-Graduação da Unesp/FCT, com quem aprendi muito e que espero ter expressado ao menos um pouco desse aprendizado nessa pesquisa. A banca do Exame de Qualificação, Professor Everaldo, que consegue ver a essência daquilo que escrevemos; e a Professora Carminha pela valiosa colaboração. Ao CNPq e a FAPESP, pelas bolsas concedidas que permitiram minha integral dedicação à pesquisa.

A Unesp/FCT (instituição, funcionários, professores...) por uma realização pessoal. A todos aqueles que contribuíram com este trabalho, nas entrevistas, no envio de material, principalmente ao Fábio Camillo, que contribuiu imensamente, respondendo inúmeros emails, enviando dados e posicionando-se frente aos acontecimentos do setor aéreo, ao Álvaro Cardoso pela entrevista e pelos contatos e ao Sr. Harro Fouquet, que cordialmente recebeu-me em sua casa, disponibilizando todo seu acervo histórico para minhas consultas.

Sem toda essa ajuda, seria pouco provável que meu esforço tivesse valido a pena. 
“A Geografia não apenas contém uma Filosofia, como toda Ciência digna desse nome, mas ela é quase, em si mesma, uma Filosofia do mundo do homem." 


\section{SUMÁRIO}

Índice.

viii

Índice de Capítulos........................................................................................ viii

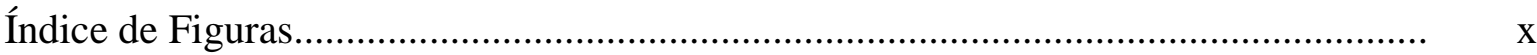

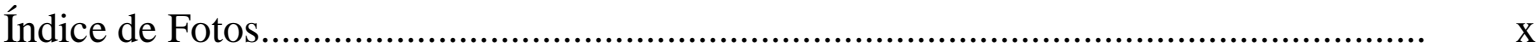

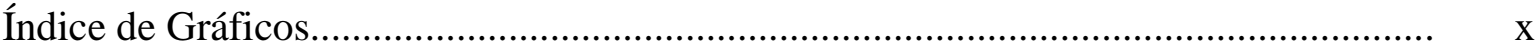

Índice de Mapas........................................................................................... xi

Índice de Quadros.................................................................................... xi

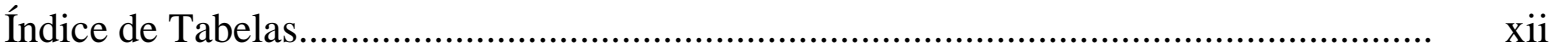

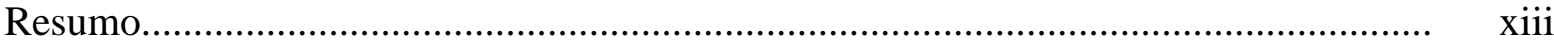

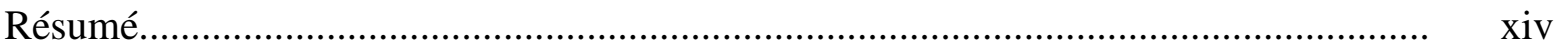

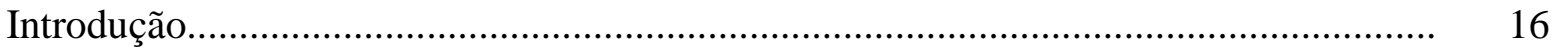

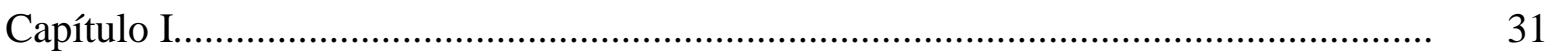

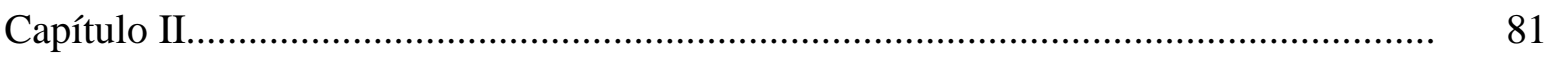

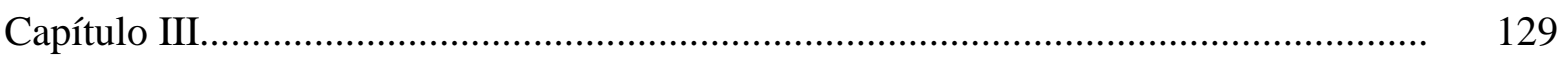

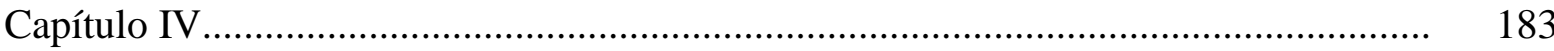

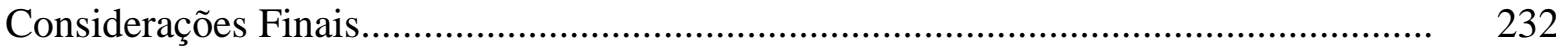

Referências Bibliográficas....................................................................................... 240

Anexos............... 251 


\section{ÍNDICE}

Introdução

CAPÍTULO I - Desenvolvimento do capitalismo e a gênese do transporte aéreo

1.1. A mundialização do capital, o meio técnico-científico-informacional e as revoluções e evoluções logísticas.....

1.2. O transporte aéreo no contexto da mundialização do capital.

1.3. Gênese e desenvolvimento do transporte aéreo brasileiro.

1.3.1. Dos primórdios da aviação comercial aos Sistemas Integrados de Transporte Aéreo Regional (1910-1980)

1.3.2. A nova fase no setor de transporte aéreo: da regulamentação à desregulamentação (1990-2007).

CAPÍTULO II - Transporte aéreo regional no Estado de São Paulo: o papel do Estado na gestão do transporte aéreo

2.1. O setor de transporte aéreo no contexto de valorização de novos espaços paulistas.

2.2. Gênese e desenvolvimento do transporte aéreo no Estado de São Paulo: a demanda e a oferta de fluxos.

2.2.1. Desconcentração produtiva e integração territorial: causa/efeito da contribuição do transporte aéreo regional.

2.3. Gestão e política de desenvolvimento do transporte aéreo regional no Estado de São Paulo

2.4. A questão infraestrutural dos complexos aeroviários no Estado de São Paulo: a necessidade de investimentos.

2.5. A proposta de concessões dos aeroportos brasileiros e a necessidade de um marco regulatório. 
CAPÍTULO III - Transporte aéreo regional no Estado de São Paulo: uma análise sobre os fluxos de passageiros

3.1. Transporte aéreo regional e as novas territorialidades: a viabilização do segmento regional.

3.2. A multiplicidade dos fluxos aéreos no interior do Estado de São Paulo: uma abordagem da rede urbana e das regiões de influência das cidades

3.2.2. Bauru/Arealva...

3.2.3. Marília

3.2.4. Presidente Prudente.

3.2.5. Ribeirão Preto

3.2.6. São José do Rio Preto.

3.2.7. São Paulo.

3.3. Considerações finais ao capítulo III.

CAPÍTULO IV - As estratégias competitivas do setor de transporte aéreo regional e suas implicações territoriais

4.1. As empresas aéreas: origem, desenvolvimento e estratégias empresariais.

4.1.1. TAM Linhas Aéreas S.A.

4.1.2. Gol Linhas Aéreas Inteligentes S.A.

4.1.3. Pantanal Linhas Aéreas S.A.

4.1.4. Passaredo Transportes Aéreos LTDA

4.2. Estratégias e vantagens competitivas: a concorrência no setor de transporte aéreo regional. 
4.3. Estratégias empresariais: cadeia de valor, inovação, diferenciação/diversificação e coerência produtiva.

4.4. O duopólio no mercado aéreo paulista: concentração ruinosa ou estratégia coordenada?

4.5. Considerações finais ao capítulo IV

Considerações Finais.

Referências Bibliográficas

Anexos.

\section{LISTA DE FIGURAS}

Figura 1 - Operações Point-to-Point.

Figura 2 - Operações Hub-and-Spoke

Figura 3 - Estrutura de mercado das Empresas Estabelecidas (TAM-Gol).

\section{LISTA DE FOTOS}

Foto 1 - Primeiros modelos de aeronaves utilizadas no Brasil.

Foto 2 - Aviões da VASP no Aeroporto de Congonhas - 1960.

Foto 3 - Área interna do Aeroporto de Araçatuba - 2008

Foto 4 - Área interna do Aeroporto de Bauru/Arealva - 2008.

Foto 5 - Área interna do Aeroporto de Marília - 2008.

Foto 6 - Área interna do Aeroporto de Presidente Prudente - 2008.

Foto 7 - Área interna do Aeroporto de Ribeirão Preto - 2008.

Foto 8 - Área interna do Aeroporto de São José do Rio Preto - 2008. 
Foto 10 - Aeroporto de Bauru/Arealva - 2006

Foto 11 - Aeroporto de Marília - 2006

Foto 12 - Aeroporto de Presidente Prudente - 2006

Foto 13 - Aeroporto de Ribeirão Preto - 2006.

Foto 14 - Aeroporto de São José do Rio Preto - 2006.

\section{LISTA DE GRÁFICOS}

Gráfico 1 - Evolução do número de passageiros transportados pelas empresas TAM, Gol e Outras empresas (1997-2007)

Gráfico 2 - Vinte aeroportos brasileiros com maior movimentação de passageiros no ano de 2007

\section{LISTA DE MAPAS}

Mapa 1- Cidades do Estado de São Paulo com autorização para operar voos regulares.. 90

Mapa 2 - Ligações aéreas no Brasil - 2009.

Coletânea de mapas 3 - Fluxos aéreos com origem em Araçatuba (1995-2007)

Coletânea de mapas 4 - Fluxos aéreos com origem em Bauru (1995-2007).

Coletânea de mapa 5 - Fluxos aéreos com origem em Marília (1995-2007)

Coletânea de mapas 6 - Fluxos aéreos com origem em Presidente Prudente (19952007)

Coletânea de mapas 7 - Fluxos aéreos com origem em Ribeirão Preto (1995-2007).......

Coletânea de mapas 8- Fluxos aéreos com origem em São José do Rio Preto (19952007)

Coletânea de mapas 9 - Fluxos aéreos com origem em São Paulo (1995-2007)

Coletânea de mapas 10 - Fluxos aéreos no Estado de São Paulo (1995-2007). 


\section{LISTA DE QUADROS}

Quadro 1 - Passageiros transportados por voos não regulares (embarque e desembarque) entre 1991-2007.

Quadro 2 - Passageiros transportados por voos regulares e não-regulares (embarque e desembarque) entre 1991-2007.

Quadro 3 - Programação de voos do Aeroporto de Araçatuba - 2008.

Quadro 4 - Programação de voos do Aeroporto de Bauru/Arealva - 2008.

Quadro 5 - Programação de voos do Aeroporto de Marília - 2008.

Quadro 6 - Programação de voos do Aeroporto de Presidente Prudente - 2008.

Quadro 7 - Programação de voos do Aeroporto de Ribeirão Preto - 2008.

Quadro 8 - Programação de voos do Aeroporto de São José do Rio Preto - 2008.

\section{LISTA DE TABELAS}

Tabela 1 - Passageiros transportados (1962-1970)......

Tabela 2 - Cidades servidas por companhias aéreas regionais e nacionais (19751980)

Tabela 3 - Evolução estatística do setor de transporte aéreo (1927-2007)

Tabela 4 - Evolução do Tráfego no Aeroporto de Congonhas (1941-2007). 94

Tabela 5 - Restrições físico-operacionais no Aeroporto de Congonhas - 2008. 95

Tabela 6 - Aeroportos Administrados pela INFRAERO - 2008. 106

Tabela 7 - Aeroportos Administrados pelo DAESP - 2008 107

Tabela 8 - Complexo aeroviário de aeroportos da INFRAERO - 2008. 109

Tabela 9 - Complexo aeroviário de aeroportos do DAESP - 2008 109

Tabela 10 - Investimentos do Governo do Estado de São Paulo em infraestrutura 114 
aeroviária (Em reais e porcentagem) - 1995 a 2007.

Tabela 11 - Rotas com destino a São Paulo por transporte rodoviário e aeroviário.

Tabela 12 - Controle acionário da empresa TAM Linhas Aéreas - 2007.

Tabela 13 - Controle acionário da empresa Gol Linhas Aéreas Inteligentes - 2007.

Tabela 14 - Despesas de comercialização com propaganda e marketing das empresas aéreas que operam no interior do Estado de São Paulo - 2007.

Tabela 15 - Modelos de aeronaves, capacidade e quantidade de aeronaves por empresa $-2008$ 


\section{RESUMO}

O presente trabalho propõe-se a uma reflexão sobre o transporte aéreo regional no Estado de São Paulo. Considera-se, para isso, que as cidades constituem elos entre os setores de produtividade e consumo, por representarem nós de rede urbana, além de definirem a desconcentração urbano-industrial no Estado. Assim, as cidades estão inseridas em uma rede de relações sociais e econômicas e possuem importante função na organização da circulação do território e na produção do espaço urbano. O modal aéreo possibilita uma maior fluidez territorial, o que torna mais flexível a superação do espaço pelo tempo. O imperativo da sociedade atual, influenciado pelo meio técnico-científico-informacional e pelas invenções e inovações tecnológicas, exige uma mobilidade que remete a uma perspectiva intensamente renovadora dos meios de transporte. $\mathrm{O}$ transporte aéreo requer infraestruturas adequadas, ou seja, os fluxos demandam fixos produtivos que balizem seu movimento, assim como necessita de planejamento, regulamentação e organização do seu mercado. Nesse sentido, apresentamos nesta pesquisa uma análise geoeconômica dos fluxos aéreos no interior do Estado de São Paulo, tendo como referencial, primeiramente, uma abordagem evolucionista do setor no Brasil, que caracteriza a sua atual situação. Em seguida, relatamos como o modal tem se desenvolvido no Estado de São Paulo, considerando a processualidade dos fatores relacionados à dinâmica dos fluxos aéreos de passageiros entre os aeroportos na interface com a capital paulista, que tem obtido um constante crescimento. Por fim, é realizada uma análise sobre o mercado de transporte aéreo, enfocando as companhias aéreas que operam no Estado, assim como suas estratégias e vantagens competitivas, que reflete o processo de duopolização e o processo de desregulamentação no setor de transporte aéreo. Em síntese, o setor aéreo tem se revelado atualmente, devido a sua dinâmica territorial em promover a circulação aérea, processando-se como um meio inovador na velocidade das ações no espaço, gerando a intensificação das interações espaciais, a integração territorial e o desenvolvimento econômico regional.

PALAVRAS-CHAVES: transporte aéreo regional; fluxos; interações espaciais; desenvolvimento econômico regional; redes 


\section{RÉSUMÉ}

Ce travail se propose à une réflexion au transport aérien régional l'état de São Paulo. On considère, pour cela, que les villes constituent des liens entre les secteurs de productivité et consommations, puisqu'ils réprésentent des nœuds du réseau urbain ; en plus, ils définent la déconcentration urbaine-industrielle dans l'état. Ainsi, les cités sont inserées dans un réseau de rapports sociaux et économiques et ont d'importante fonction dans l'aménagement de la circulation du territoire et dans les productions de l'espace urbain. Le modal aérien possibilite une plus grande fluidité territoriale, ce qui rend plus flexible la supération de l'espace par le temps. L'impératif de la société actuelle, influencé par le moyen technique-cientifiqueinformationnel et par les inventions et les inovations technologiques, demande une mobilité qui fait appel à une perspective intensement renovatrice des moyens de transport. Le transport aérien demande de l'infrastructure adéquate, c'est-à-dire, les flux demandent des fixes productifs qui conduisent leur mouvement, bien qu'il a besoin de projetement, reglémentation e aménengement de leur marché. Dans ce sens, nous présentons dans cette recherche une analyse géoéconomique des flux aériens à l'intérieur de l'état de São Paulo, ayant comme référentiel, d'abord, une approche evolutioniste du secteur au Brésil, qui caractérise la situation actuelle. À la suíte, nous racontons comme le modal se développe dans l'état de São Paulo, en considérant l'echaînement des factures liés à la dynamique des flux aériens des voyageurs parmi les aéroports dans l'interface avec la capitale de cet état, qui obtient une croissance constante. Finalement, est faite une analyse du marché du transport aérien, en focalisant les compagnies aériennes qui opèrent dans l'état, bien que leurs stratégies et avantages competitives, qui montre les processus de déréglementation et manque de reglémentation. En somme, le secteur aérien se révèle, actuellement, à cause de la dynamique territoriale, pour promouvoir la circulation aérienne, en se traitant d'un moyen inovateur dans la vitesse des actions dans l'espace et en causant l'intensification des intéractions espaciales, l'intégration territoriale et le développement régional.

MOTS-CLÉS: transport aérien régional, flux, intéractions espaciales, développement économique regional, réseaux 
INTRODUÇÃO 
O "fazer circular" é a lógica empreendida pela sociedade e pelo capital.

A introdução deste trabalho faz-me discorrer sobre um gradual (embora intensivamente veloz) processo de desenvolvimento da pesquisa e de desenvolvimento acadêmico. Em outras palavras, a pesquisa ensinou que o "fazer circular" é, ao mesmo tempo, teoria e prática cotidiana.

Embora a generalização do termo "circulação" tramite pelos diversos campos da Ciência, observamos que a circulação empreende primeiramente a fluidez territorial, constituindo-se a partir da movimentação de pessoas, mercadorias, informações, valores etc. Nessas condições, ressaltamos a importância de compreender a circulação num processo amplo, considerando para isso o transporte aéreo como um importante modal representante do processo de circulação. Buscamos com isso, compreender a circulação mediante a abordagem de elementos indissociáveis ao exame da Geografia, como por exemplo, as interações espaciais, as redes geográficas, o desenvolvimento regional, a mobilidade territorial, os fixos, os fluxos entre demais condicionantes que são essenciais para produção e reprodução do espaço geográfico.

Propomos, nesta introdução, dividir todo o processo de desenvolvimento da pesquisa, como forma de torná-la, sucintamente mais clara e objetiva e menos factual e introdutória. Assim apresentamos o desenvolvimento científico deste trabalho que chamamos de enquadramento teórico-metodológico. Dividimos, portanto, as partes em:

1- Contextualização da temática: apresentação do tema, da problemática, dos recortes espacial e temporal;

2- Metodologia: apresentação dos procedimentos realizados no desenvolvimento deste trabalho e;

3- Breve apresentação dos capítulos: introdução dos capítulos desenvolvidos no trabalho.

Procuramos, desta forma, elucidar todo encaminhamento da pesquisa, enfatizando sua proposição teórica, em termos de levantamento bibliográfico, leituras, sínteses, fichamentos, artigos, traduções, análises teóricas, discussões, debates e questionamentos, assim como todo processo de desenvolvimento do trabalho de campo, como roteiros de entrevistas, transcrições, tratamento e processamento de dados, análises empíricas, elaboração de cartogramas, mapas, tabelas, gráficos, tratamento das imagens etc.

A contextualização da temática baseou-se, em termos de objeto, no transporte aéreo regional e regular de passageiros. Em relação à análise espacial, particularizamos o 
Estado de São Paulo, mais precisamente as cidades do interior ${ }^{1}$ que possuem aeroportos regulares. Finalizando a contextualização temática, realizou-se uma análise temporal, que permeou a cronologia do desenvolvimento da aviação comercial no Brasil dos anos de 1910 até os dias atuais. Já na análise dos dados estatísticos, exploramos os anos de 1995 a 2007.

$\mathrm{O}$ interesse pelo transporte aéreo regional decorre do fato de ser esse um estudo de pouca abordagem na Geografia. Nessa perspectiva, procurou-se desenvolver um trabalho que abordasse como objeto o transporte aéreo, considerando-o como um importante meio de integração territorial e, também, como um elemento indutor das interações espaciais, da conformação das redes geográficas e fomentador do desenvolvimento econômico regional.

A abordagem espacial processou-se mediante a necessidade de se realizar trabalhos na escala regional, enfocando sua representatividade para a economia do Estado, sua magnitude na capacidade de geração de tráfego e, igualmente, o desenvolvimento regional das cidades com potencial para o setor aeroviário.

A análise enfatizou os deslocamentos de passageiros, devido ao fato de este ser o mais importante para o transporte aéreo e, ainda, em razão das cidades pesquisadas serem as maiores geradoras de tráfego aéreo regional de passageiros do país².

No Estado de São Paulo existem 36 aeroportos que operam voos regulares e nãoregulares. O Estado é retratado, numa escala nacional, como um importante elo de conexão espacial entre os territórios e, ainda, abriga os mais movimentados aeroportos do país, como o Aeroporto de Congonhas, Aeroporto de Guarulhos/Cumbica e o Aeroporto de Viracopos. Estes fixos correspondem às principais ligações aéreas regionais do Estado de São Paulo e favorecem os fluxos aéreos regionais que se conformam na rede geográfica aérea a partir de seus nós, ou seja, dos aeroportos.

Analisar o tráfego aéreo regional em cidades do Estado de São Paulo requer uma análise de dados estatísticos que compreendem os resultados apresentados por entidades

\footnotetext{
${ }^{1}$ Nossa análise parte de uma perspectiva que trata as cidades do interior do Estado de São Paulo, que embora a maioria se caracterize como cidade média, não as circunscrevemos como tal, uma vez que a caracterização, a organização econômica e a dinâmica empreendida por algumas das cidades pesquisadas ultrapassam a nomenclatura utilizada atualmente na ciência geográfica. Salientamos que, de acordo com Beltrão Sposito et al (2007), para conceituar uma determinada cidade como grande, média ou pequena é necessário uma posição teórico-metodológica de estudo, já que as cidades possuem especificidades que se colocam como desafios para conceituá-las. Enfatizamos, ainda, que embora tratemos este trabalho numa escala que perpasse a análise estritamente econômica, aproximando por vezes da Geografia Urbana, esta pesquisa tem como objetivo referenciar os fluxos aéreos na perspectiva da Geografia dos Transportes, da Circulação e da Logística.

${ }^{2} \mathrm{O}$ transporte aéreo de cargas, assim como o transporte aéreo para correio, perfaz importantes deslocamentos para a análise de dados. Todavia, retratam um ramo de pouca representatividade para o setor de transporte aéreo, devido os valores cobrados no transporte de mercadorias e cargas, como também as restrições relacionadas ao tipo de carga. Soma-se a isso também o encerramento do tráfego de produtos movimentados para correio no ano de 2006 nas cidades paulistas analisadas.
} 
administrativas, como o DAESP (Departamento Aeroviário do Estado de São Paulo), a INFRAERO (Empresa de Infraestrutura Aeroportuária), a ANAC (Agência Nacional da Aviação Civil), a Secretaria dos Transportes etc., e também os dados publicados pelas empresas do setor aéreo. Sendo assim, optamos em trabalhar com o transporte aéreo regular, devido à disponibilização de dados mais precisos e, acredita-se, que correspondentemente reais. De acordo com os termos técnicos utilizados pela aviação na computação de dados estatísticos, o transporte aéreo regular é a ligação aérea entre duas ou mais localidades, caracterizadas por um número, através do qual é executado serviço regular de transporte aéreo, de acordo com horário, linha, equipamento e frequência, previstos em HOTRAN (Horário de Transporte) ${ }^{3}$. Todas as outras situações são consideradas como voos nãoregulares, tais como voos fretados, chaters, táxi-aéreo entre outros.

As cidades pesquisadas têm apresentado índices positivos (com algumas exceções) no deslocamento de passageiros pelo modal aéreo. O crescente número de passageiros transportados tem demandado investimentos em infraestrutura técnica $\mathrm{e}$ operacional. A questão infraestrutural dos aeroportos revela a inoperância no planejamento e projetamento governamental para o transporte aéreo regional paulista, o que tem descaracterizado o setor e prejudicado suas operações, diminuindo, desta forma, o número de empresas que oferecem o serviço no Estado, assim como o número de linhas aéreas.

A problemática do transporte aéreo regional é enfatizada neste trabalho mediante a análise do setor no Estado, considerando a atuação estatal (Governo) e privada (empresas aéreas). Assim, atentamos para a verificação dos gargalos que dificultam e, por vezes, impedem o desenvolvimento do transporte aéreo no Estado de São Paulo. As cidades paulistas com aeroportos regulares têm demonstrado que as operações aéreas registradas potencializam-nas como importantes centros geradores de circulação. Alguns centros urbanos merecem um maior destaque, devido ao fato de consubstanciarem-se como elos entre os setores de produção e consumo e por definirem-se como potenciais setores na especialização produtiva para o transporte aéreo. Consideramos, assim, no desenvolvimento da pesquisa, que estas cidades podem dinamizar o setor e constituir um sistema de $h u b^{4}$ regional ou secundário no interior paulista. Para isso os problemas das condições gerais de produção, a questão da

\footnotetext{
${ }^{3}$ HOTRAN é a informação de um voo regular (horário, local, escalas, equipamento etc.) solicitado pela companhia aérea ao órgão regulador (OLIVEIRA, 2009).

${ }^{4} \mathrm{Hub}$ é o aeroporto onde as empresas centralizam suas operações. A partir deste aeroporto as companhias espalham conexões para cidades com menor demanda. A organização técnica dos hubs faz com que os voos concentrem-se na mesma faixa horária num determinado aeroporto viabilizando as conexões necessárias para os passageiros, isso permite que o transporte aéreo continue atendendo localidades que apresentam baixa densidade de fluxos/passageiros (COELHO, 2003).
} 
infraestrutura operacional dos aeroportos, o planejamento estratégico, entre demais fatores, necessitam de uma maior atenção do Estado.

No que tange ao recorte temporal, analisamos o transporte aéreo em duas abordagens: a primeira é pormenorizada no primeiro capítulo - que trata da aviação desde suas primeiras atividades em território nacional, em 1910, até os dias atuais - considerando como que sua política de estratégia para a integração territorial contribui para o setor, assim como para todo o processo de reestruturação do transporte aéreo e o atual contexto políticoeconômico de desregulamentação. Referimo-nos, em um primeiro momento, a uma abordagem histórico-desenvolvimentista; esta introdução da temática facilita a compreensão das constantes crises conjunturais ${ }^{5}$ pela qual o modal aéreo perpassa.

Numa segunda análise tratamos a abordagem empírica dos dados de fluxos de passageiros, delimitando os anos de 1995 a 2007. A escolha pelo recorte temporal refere-se a disponibilização dos dados estatísticos das entidades administradoras. Um incêndio no Aeroporto de Santos Dummont no Rio de Janeiro, no ano de 1996, comprometeu os anuários estatísticos dos anos anteriores a 1995, o que impossibilitou o tratamento dos dados de anos anteriores. Desta forma, nossa análise permeou os anuários remanescentes, isto é, do ano de 1995 até 2007, este último ano refere-se aos dados mais recentes e disponibilizados. Os dados de anos anteriores a 1995 foram possíveis de averiguação no acervo histórico do Sr. Harro Fouquet, que trabalhou na aviação comercial desde os anos de 1940, arquivando um conjunto de materiais sobre o transporte aéreo brasileiro. Embora de grande valia para o desenvolvimento desta pesquisa, os dados, o material, os anuários não possuem a periodicidade de que precisamos, ou seja, ano a ano, fazendo com que optássemos pelos dados disponíveis pelas entidades administradoras.

\footnotetext{
${ }^{5}$ É importante iniciar este trabalho explicando o que consideramos como "crise aérea" no Brasil. Quando tratamos esta questão referimo-nos a uma crise conjuntural, isto é, que advém de vários fatores que acentuaram os problemas relativos ao setor aéreo brasileiro. Dentre esses fatores destacamos que a crise aérea foi e é ampliada em razão do: A.) processo de desregulamentação adotado pelo setor aéreo brasileiro que foi, sem dúvida, o maior agravante da crise aérea, uma vez que gerou a ausência da ação de um Estado regulamentador na chamada normatização do setor em favor do bem estar dos usuários. B.) Outro fator de grande importância é a concorrência predatória por parte das empresas que alimentam ainda mais esta problemática. Na ausência de normas que padronizem o setor, as empresas agem a livre iniciativa do mercado, acarretando desajustes para o transporte aéreo. C.) A precarização infraestrutural dos aeroportos também se caracteriza como mais um fator que incide na proporcionalidade da crise aérea atual. D.) Assinalamos ainda que os acontecimentos externos também afetaram o setor aéreo no Brasil, o "11 de setembro de 2001" com os ataques terroristas resvalou no Brasil uma diminuição do tráfego aéreo, sobretudo internacional, acentuando a crise. E.) Mesmo o transporte aéreo sendo considerado o meio de locomoção mais seguro, os acidentes aéreos impactam diretamente na utilização do modal, desta forma, os acidentes ocorridos com a empresa Gol, TAM e Air France em 2006, 2007 e 2009 respectivamente, agravaram ainda mais os problemas do setor. Assim, consideramos que a crise aérea é um conjunto de fatores que estão intimamente ligados e que somados geram uma crise conjuntural que o mercado aéreo convive atualmente.
} 
Em síntese, apresentamos a contextualização temática da pesquisa como forma de introduzir a formulação teórica e empírica abordada no trabalho, reportando-nos aos recortes analisados como o objeto, a problemática, o espaço e o tempo.

Enfatizamos que o método utilizado partiu de uma visão pragmática da pesquisa (LÊNINE, 1980; CHEPTULIN, 1982; SPOSITO, 2004). Desta forma, encaramos o método como a expressão maior desta concepção, o que nos induziu a compreender e realizar a pesquisa numa perspectiva dialética de construção, investigação, conhecimento e análise.

Partimos dessa analogia como forma de compreender que não há nada de definitivo, absoluto, de sagrado na filosofia dialética. Nessa lógica, evidenciamos a partir da concepção de Karl Marx, que a dialética compreende uma teorização do conhecimento que deve considerar o seu objeto como um movimento histórico, o qual estuda e generaliza a origem e o desenvolvimento do conhecimento (LÊNINE, 1980).

Portanto, essa pesquisa baseada neste método procura considerar a análise proposta como um conjunto de processos em transformação, que mediante a investigação e o conhecimento, propriamente dito, da base empírica nos permite conhecer e investigar o movimento histórico do transporte aéreo no Brasil e, principalmente no Estado de São Paulo.

A metodologia utilizada buscou abarcar a definição de termos, descrições, analogias, contradições e definições de alguns elementos que se tornaram essenciais na pesquisa, tais como: interações espaciais, redes geográficas, desenvolvimento regional e circulação, termos que são proeminentes na Geografia. Objetivamos, nesta pesquisa, e também em demais trabalhos, artigos, debates no Grupo de Estudo em Desenvolvimento Regional e Infraestrutura (GEDRI), construir um referencial teórico que defina as posições, observações e pesquisas desenvolvidas. A tarefa é árdua. No entanto, a aplicabilidade do desenvolvimento desse referencial tem possibilitado às pesquisas um processo de organização e padronização dos conceitos, termos e definições construídas no interior das discussões e dos debates realizados pelo Grupo.

Nessas condições, alguns autores foram inerentes para compreender os elementos essenciais da pesquisa. Para análise das interações espaciais foram fundamentais as leituras de Corrêa (1977, 1997, 1999, 2007), Ullman (1972) e Beguin (1995). Ressalvadas suas diferenciações, estes autores tratam as interações espaciais mediante a movimentação, a mobilidade e em alguns casos, a partir dos transportes. Consideram, portanto, que as interações espaciais são complexidades das relações sociais e da integração territorial, portanto é a partir das interações espaciais que se observa a constituição territorial das 
cidades, isto é, as interações espaciais propiciam uma vida de relações, na qual se dão e se complementam as relações sociais, a economia, a cultura, a normas, as técnicas, a política etc.

Partindo dessa lógica, quando tratamos as redes geográficas observamos diferentes e conflitantes abordagens, que ora perfazem uma mesma situação, apenas com conceituações diversas, ora são incisivamente discrepantes. Sendo assim, nossa análise buscou compreender as redes geográficas a partir da mobilidade territorial, isto é, mediante os sistemas de movimento. Os autores que mais contribuíram para esta abordagem tratam o termo a partir de uma definição que considera as redes e as bases de conformação das mesmas. Em outras palavras, foi em Dias (2005) e em Castells (2001) que encontramos as correlações para compreender as redes geográficas em seu movimento análogo com os sistemas de objetos, ou seja, com os aeroportos, com as cidades, com o mercado, propriamente dito. Contudo, ressaltamos que a necessidade de abordagens que tratem as redes geográficas mediante os transportes é essencial e urgente.

Já ao consideramos o desenvolvimento regional, temos inúmeras pesquisas que abordam a temática em sentido amplo. Assim, buscamos correlacionar nossa abordagem geoeconômica justapondo a análise do desenvolvimento urbano e regional. Para isso tratamos as cidades, seus respectivos entornos, bem como o desenvolvimento econômico dos espaços aqui tratados. Em tal abordagem, consideramos as análises Limonad (2002), Arroyo (2006), Beltrão Sposito (2001, 2007) e Sposito (1999), que retratam o espaço urbano e regional mediante diversas análises.

No que tange a circulação, incidimos, sobretudo, numa articulação com o “circuito espacial da produção" referenciada por Santos (2003). Nessa análise, procuramos abordar, ainda que preliminarmente, uma relação existente no que chamamos de "circuito espacial da circulação". Embora, exploremos sucintamente essa definição, elaborada e explorada por nós, buscamos inseri-la como forma de compreender o movimento geográfico dos fluxos, ou melhor, procuramos incorporar esta inicial análise, no sentido que relacionar a fluidez, as redes, os nós das redes e os deslocamentos espaciais. Ainda sobre a circulação, as abordagens de Pini (1995) foram essenciais para nossa análise, uma vez que este autor considera a mobilidade territorial de pessoas, mercadorias, informações etc., como elemento primordial para a materialização da circulação.

É importante destacar que as leituras de Santos (2002, 2003, 2004, 2005) foram intensivamente destacadas, já que estas abordam um conjunto de elementos que contribuíram para formulação da pesquisa. Estas leituras possibilitaram a utilização de termos como sistema de objetos e sistemas de ações, fixos, fluxos, circulação entre outros. 
As leituras de Silveira (2006, 2007, 2009, 2009a) aprofundaram a abordagem sobre a difusão da inovação das tecnologias, as revoluções e evoluções logísticas e permitiram compreender o desenvolvimento dos transportes no Brasil. Os textos partem de uma perspectiva geoeconômica que contempla as análises espaciais e temporais sobre o desenvolvimento dos meios de transportes, projetando-se mediante uma abordagem que trata de questões políticas como o papel do Estado no projetamento e planejamento dos meios de transportes, as implicações territoriais etc.

A abordagem das leituras de Ignácio Rangel $(1983,2005)$ foi essencial para a discussão sobre o desenvolvimento econômico brasileiro, sobre a presença do Estado e a eficácia do projetamento setorial, uma vez que conformaram a necessidade de aludir-se à questão infraestrutural do modelo idealizado pelo autor - de transferência de recursos ociosos à iniciativa privada.

Numa perspectiva mais geral, algumas análises que trabalharam temas diversos foram utilizadas e extremamente positivas para o desenvolvimento da pesquisa. É importante destacar que Ramos (1998) contribuiu sobremaneira para este trabalho, ao tratar das interações espaciais a partir das redes geográficas no Estado de São Paulo. Lencioni (1994, 2003) também oferece grande contribuição teórica para diversas análises sobre o Estado de São Paulo, em razão de contextualizar historicamente o processo de reestruturação urbanoindustrial.

Dentro dessa óptica, ressaltamos ainda os trabalhos de Cholley (1974), Chesnais (1996), Benko (1996), Derruau (1982), Harvey (1992, 2006), Raffestin (1993) que, em suas diferentes análises, possibilitaram a busca por referenciais, tais como: as combinações geográficas, a mobilidade do capital, as relações espaço-tempo, o mercado e a economia, os transportes, o território, as redes, o poder de ação dos agentes econômicos etc.

Em um contexto mais específico sobre o transporte aéreo, a ênfase da análise considerou um conjunto de pesquisas de múltiplas áreas científicas. Ressaltamos tal fato, primeiro, pela quase ausência de trabalhos sobre o tema referente ao transportes aéreo na Geografia e; segundo, porque o caminhar pelos demais ramos da Ciência (Engenharia, Economia, Sociologia, História, Administração entre outras) possibilitou compreender os diversos enfoques dado ao setor aéreo, nos permitindo, assim, traçar um olhar geográfico sobre o tema.

Assim sendo, a busca pelos trabalhos que tinham como temática o modal aéreo perfaziam abordagens que favoreceram, de alguma forma, uma análise conceitual do tema, permitindo organizar um "leque" de observações que tinham como recortes variadas análises. 
Entre os autores que pesquisaram o transporte aéreo, dividimos os estudos de acordo com a escala de abrangência, ou seja, autores que trabalharam o segmento internacional, nacional, regional, de cargas, de passageiros, e ainda aqueles que trabalharam a questão da infraestrutura, política de desregulamentação, meio ambiente, indústria aeronáutica, demanda, empresas aéreas, análises das entidades de administração etc. Aludimos que, embora a Geografia não particularize o transporte, e menos ainda o modal aéreo, as demais Ciências têm investido nessa leitura e têm avançado em relação as suas abordagens.

Nesse contexto de análise, é importante destacar os trabalhos de Porter (1986, 1989, 1996, 1999), bem como os trabalhos de Kupfer (1996, 2002) e Hasenclever (2002). Embora as divergências das análises tenham ampliado as discussões e as contradições, estes autores foram destacados por trazerem grandes contribuições para as leituras sobre as empresas, sobre as estratégias e as vantagens competitivas, que restauram um debate extremamente interessante, do ponto de vista da compreensão da dinâmica do mercado.

Buscamos assim, em um primeiro momento, compreender o que é o transporte aéreo e como se deu o desenvolvimento e a evolução do setor, em especial do segmento regional no Brasil e, posteriormente, no Estado de São Paulo. Para isso, partimos da correlação entre os fatores que propiciaram tal intento, procurando analisar as relações e as implicações territoriais do desenvolvimento do modal aéreo nas cidades estudadas. Assim, procuramos demonstrar como que o transporte aéreo contribuiu para a dinâmica econômica regional, todavia considerando a relação de consequência existente entre esse objeto (o modal) e o sujeito (as cidades e suas regiões de influência, bem como a sociedade).

Nesse aspecto, é importante deixar claro que metodologicamente partiu-se de análises empíricas e teóricas (conceitos, temas, teorias e categorias) que buscaram compreender o setor aéreo em seu movimento histórico e dialético, como forma de observar a variação, o movimento, o processo de evolução do setor e suas repercussões no território paulista.

Tivemos sempre a preocupação de compreender o transporte aéreo regional considerando dois aspectos inerentes a sua dinâmica espacial territorial: o processamento das interações espaciais e o desenvolvimento econômico regional. Nesse sentido, observamos que o transporte aéreo contribui para a intensificação das interações espaciais, assim como se releva como um setor indutor de desenvolvimento econômico regional no Estado de São Paulo.

Com isso, partimos, primeiramente, de um levantamento bibliográfico que teve como fator principal elencar trabalhos que direta ou indiretamente contribuíram para o 
entendimento do transporte aéreo. Esta etapa foi realizada em dois momentos; estes podem ser descritos como: A. levantamento bibliográfico teórico-conceitual e B. levantamento bibliográfico temático.

A etapa "A" foi realizada como forma de se enquadrar o tema, já proposto, com o referencial teórico utilizado pelo GEDRI. No entanto, ressaltamos que esse levantamento buscou demais leituras, como forma de tornar mais exequível a análise temática. A etapa "B" procurou organizar o material específico que tratava do transporte aéreo em suas múltiplas compreensões. Desta forma, nesta etapa, formulou-se um quadro analítico de temas relacionados ao modal, verificando e distribuindo as análises realizadas nos trabalhos de acordo com suas definições. É importante destacar que esta divisão de abordagens foi necessária tendo em vista a amplitude de análises realizadas nos diversos campos da Ciência, o que impossibilitou que todos os trabalhos fossem compreendidos na mesma proporção.

Posterior a esse primeiro contato com o tema, partimos para a primeira etapa do trabalho empírico. Assim, realizamos entrevistas e coleta de material que possibilitaram o entendimento prático da administração do setor aéreo no Estado de São Paulo e, também, permitiram a verificação da história do serviço de aviação comercial no Brasil.

As entrevistas seguiram um roteiro de perguntas que pretendiam sanar as dúvidas e lacunas do primeiro e do segundo capítulos da dissertação, mas também fornecer maiores questionamentos sobre as etapas subsequentes. Nesse sentido, a segunda etapa de entrevistas e pesquisas de campo foi sistematicamente configurando nossas análises e com isso permitiu uma melhor compreensão sobre o setor aéreo paulista.

Por fim, compreendemos que, mediante os objetivos traçados no pré-projeto, procuramos correspondentemente respondê-los. Sendo assim, nosso objetivo geral buscou compreender e analisar a dinâmica territorial realizada pelo setor aéreo em aeroportos regulares do Estado de São Paulo, configurando a importância do setor aéreo nas cidades de Araçatuba, Bauru, Marília, Presidente Prudente, Ribeirão Preto e São José do Rio Preto e suas interconexões com a metrópole paulista. Os objetivos específicos tiveram como meta: 1- Analisar a gênese e o desenvolvimento dos fluxos aéreos regionais no Estado de São Paulo; 2- Verificar a influência da desconcentração urbano-industrial da metrópole paulista no aumento dos fluxos de passageiros nas cidades supracitadas; 3- Relacionar e identificar os fluxos entre as cidades pesquisadas com a metrópole; 4- Verificar as estratégias logísticas e competitivas adotadas pelas empresas aéreas regionais; 5- Compreender as interações espaciais causadas pela fluidez aérea no Estado de São Paulo e a relação das cidades 
pesquisadas com a metrópole paulista e; 6- Identificar a contribuição da recente dinâmica aeroviária para a compreensão do desenvolvimento regional.

A partir dessa análise, inserimos uma breve apresentação dos capítulos desenvolvidos que buscaram responder os objetivos já destacados. Os capítulos da dissertação foram previamente estruturados, seguindo um roteiro que partiu da cronologia dos fatos e fatores correspondentes ao transporte aéreo no Brasil e no Estado de São Paulo.

Neste contexto de análise, a dissertação elenca quatros capítulos.

O Capítulo I - Desenvolvimento do capitalismo e a gênese do transporte aéreo, consubstancia-se a partir de uma abordagem teórico-histórica sobre o transporte aéreo no Brasil, datando suas principais atividades no decorrer dos anos. Para tanto, traçamos uma linha cronológica que trata do setor desde o ano de 1910, formulando um contexto retratado por décadas, caracterizando, com isso, o primeiro recorte temporal realizado na pesquisa.

Mediante esta análise, aborda-se, ainda, a mundialização do capital, o meio técnico-científico-informacional e as revoluções e evoluções logísticas como forma de configurar o processo histórico às compreensões e formulações atuais sobre a modernização dos meios de transportes, em especial, do aéreo, baseado no contexto da mundialização. Ressalta-se o desenvolvimento do transporte aéreo nos Estados Unidos, enfocando a influência de suas medidas políticas e econômicas sobre outros países.

Nessa perspectiva, partimos para o enfoque mais específico, discorrendo sobre o modal no Brasil. Esta análise é subdivida em partes que retratam o setor aéreo. Assim iniciamos nossa abordagem considerando os primórdios da aviação comercial até a criação dos Sistemas Integrados de Transporte Aéreo Regional, o que confirma o primeiro momento de interesse pelo desenvolvimento do transporte aéreo regional. Adiante se enfoca a nova fase no setor de transporte aéreo, enfatizando desde a regulamentação à desregulamentação, no qual é focalizada a iniciativa de flexibilização do setor de transporte aéreo. Fechando o capítulo inicial da pesquisa, apresentam-se algumas considerações sobre o que foi tratado.

A fase seguinte da dissertação, ou seja, Capítulo II - O papel do Estado na gestão do transporte aéreo regional paulista, propõe-se a uma leitura sobre o transporte aéreo regional no contexto de valorização espacial do Estado de São Paulo. Segue-se, nessa mesma linha, uma análise sobre a gênese e o desenvolvimento do transporte aéreo paulista.

Como forma de elucidar o tratamento dado ao transporte aéreo regional paulista, a partir de uma leitura mais objetiva e correspondente análoga aos acontecimentos que retrataram o desenvolvimento do Estado de São Paulo, é realizada uma abordagem sobre a desconcentração produtiva e o processo de integração territorial buscado pelos Governos 
paulistas. Tal abordagem refere-se, assim, à causa e ao efeito da contribuição do transporte aéreo regional para o Estado.

Esse enfoque nos reporta à compreensão da ação estatal mediante o transporte aéreo. Nesse sentido, buscamos enfocar a gestão e a política de desenvolvimento do transporte aéreo regional no Estado de São Paulo, analisando, assim, o papel desempenhado pelas entidades gestoras do setor no Brasil e, principalmente, no território paulista.

Complementando a análise, segue-se, ainda, uma abordagem sobre a questão infraestrutural dos complexos aeroviários nas cidades paulistas, focalizando a necessidade dos investimentos no setor em âmbito regional e uma breve consideração sobre o atual processo da proposta de concessões dos aeroportos brasileiros. Concluímos confirmando as questões analisadas no texto de acordo com as considerações finais a este capítulo.

Em seguida apresentamos o Capítulo III - Transporte aéreo regional no Estado de São Paulo: uma análise sobre os fluxos de passageiros; que trata de forma mais específica o transporte aéreo regional a partir dos fluxos, da fluidez territorial e da demanda pelo modal, abordando-se a segunda análise temporal do trabalho. Nesta, referimo-nos ao crescimento do setor aéreo regional, contextualizando o modal e as novas territorialidades, ou seja, as cidades com aeroportos regulares, tendo como objetivo identificar a viabilização do setor a partir do segmento regional. Nesse parâmetro, é realizada uma análise destes espaços urbanos, partindo da programação dos voos dos aeroportos correspondentes e da frequência de seus fluxos.

Desta forma, identificamos o setor aéreo regional numa análise que convém chamar numericamente elucidativa. Referimo-nos ao tratamento designado a multiplicidade dos fluxos aéreos no Estado de São Paulo, o qual foi examinado e compreendido de acordo com a demanda pelo modal aéreo, pelo número de passageiros transportados, que foram expressos nos mapas, cartogramas e gráficos. Buscou-se demonstrar a configuração territorial realizada pelo transporte aéreo no Estado de São Paulo.

Seguindo nessa análise, iniciamos o Capítulo IV - As estratégias competitivas do setor de transporte aéreo regional e as implicações territoriais, abordando as empresas aéreas que operam nas cidades mencionadas. A partir dessa abordagem empírica realizamos uma breve apresentação sobre as empresas aéreas e seus padrões territoriais, isto é, os territórios de atuação, assim como o papel do Estado e dos órgãos que administram o setor.

Nessa perspectiva procuramos observar quais as implicações das estratégias empresariais dessas empresas para as cidades analisadas. Assim, este capítulo refere-se as empresas aéreas e suas estratégias de mercado, confirmando um conjunto de situações que remetem a compreensão sobre as inovações tecnológicas, sobre a imagem das empresas no 
mercado, bem como suas estratégias de concorrência e cooperação, cruciais para compreender todo o desenvolvimento mercadológico no qual está inserido o transporte aéreo regional paulista.

Em síntese, procuramos compreender o transporte aéreo regional no Estado de São Paulo, abordando suas especificidades a partir de uma análise geoeconômica sobre os fluxos aéreos de passageiros. 


\section{CAPÍTULO I}

\section{DESENVOLVIMENTO DO CAPITALISMO E GÊNESE DO TRANSPORTE AÉREO}


Este primeiro capítulo traz uma análise sobre o desenvolvimento do transporte aéreo, baseado no sistema capitalista de produção e consumo. Para tanto, discorre-se sobre alguns fatores essenciais que estruturaram e ainda organizam o setor de transporte aéreo, compreendendo uma escala que se reporta do global ao regional.

O desenvolvimento do transporte aéreo deu-se com o crescimento e intensificação do sistema capitalista. As formas, as técnicas, a produção, o uso, fazem parte de um processo análogo ao modo de produção capitalista. O capitalismo é, portanto, muito dinâmico e inevitavelmente expansível; cria uma força permanentemente revolucionária, que incessante e constantemente, reforma o mundo em que vivemos (HARVEY, 2006).

Nesse parâmetro de análise configuram-se como essenciais para esta abordagem as revoluções e evoluções logísticas (SILVEIRA, 2009), bem como o meio técnico-científicoinformacional (SANTOS, 2002) evidenciados a partir do contexto das invenções e inovações tecnológicas. As mudanças na organização territorial, nos costumes, na cultura, na economia, favoreceram a modernização dos equipamentos de circulação, a especialização produtiva, bem como a evolução das formas de transportes que se tornaram mais velozes e mais tecnicamente capacitados para os deslocamentos materiais e imateriais que por sua vez intensificaram as metamorfoses na sociedade.

Atrelados às transformações advindas do meio técnico-científico-informacional e resultantes das revoluções e evoluções logísticas, encontram-se o desenvolvimento do capitalismo e a mundialização do capital (CHESNAIS, 1996), que têm impulsionado novos padrões de produção e consumo, entre eles a utilização do transporte aéreo como um modal resultante de processos correlatos à modernização dos meios de transportes, ou melhor, dos sistemas de objetos que são processados para dinamização da velocidade dos sistemas de ações (SANTOS, 1996).

É nesse sentido que, ao analisar o transporte aéreo no período atual, consubstanciado pelas formas espaciais de produção e de consumo, entendemos que esse processo reforça a compreensão das novas tecnologias que transformam os territórios na lógica da circulação do capital. Para tanto, consideramos a globalização econômica (GONÇALVES, 2003) no período em que relaciona a modernização e adaptação dos territórios aos novos padrões tecnológicos que, sistematicamente, são induzidos pelos grandes centros econômicos.

A relação existente entre os acontecimentos ocorridos no setor aéreo mundial com o setor no Brasil fez com que traçássemos um paralelo entre o desenvolvimento do transporte aéreo nos Estados Unidos com o desenvolvimento do setor no Brasil, ora pelos fatos serem 
relativamente correlatos e ora pela influência exercida pelo setor norte-americano no Brasil, norteando os rumos para o desenvolvimento do transporte aéreo brasileiro. Esclarecemos, ainda, que tal análise está relacionada à normatização aérea dos Estados Unidos, que diretamente influencia o setor em outros países, sendo com isso, explicado os critérios de comparação que realizamos. Nessa mesma abordagem, destacamos que este país caracterizase por possuir o segmento aéreo regional mais desenvolvido mundialmente, o que nos remete a uma comparação das ações normativas realizadas neste país e suas influências no Brasil. No entanto, ressaltamos que essa abordagem é meramente comparativa, sendo que o Brasil possui sua base de tráfego aéreo independente das ações e medidas adotadas pelos Estados Unidos. Esse trabalho, portanto, busca tratar das especificidades normativas do transporte aéreo no Brasil, com destaque para o Estado de São Paulo.

Assim, na contextualização desse primeiro capítulo, é inerente a apresentação da evolução do setor de transporte aéreo brasileiro, não como historização dos fatos, mas sim como forma de reforçar a representatividade do setor e introduzir a leitura de forma que se compreenda a periodização dos acontecimentos desde a década de 1910 até o recente ano de 2007, passando pelos diversos âmbitos da história da aviação comercial brasileira, permeando o planejamento para o desenvolvimento dos meios de transporte no Brasil. Nessa perspectiva de análise, evidenciamos, também, o surgimento das principais companhias aéreas e, consequentemente, a falência ou fusão de outras, bem como a atual crise em que se insere o setor e as empresas do ramo.

Esta retrospectiva do desenvolvimento aéreo brasileiro se dá, principalmente, pela ausência de trabalhos que abordam a temática do transporte aéreo no Brasil, sendo para isso essencial a análise que ilustra a evolução do setor e evidencia as propostas veiculadas que podem dinamizar e intensificar o desenvolvimento do transporte aéreo em âmbito regional.

Nesse contexto, é necessário, primeiramente, aprofundar a discussão sobre o termo "transporte aéreo regional" como forma de padronizar todo o contexto de análise que permeia a discussão sobre o tema em questão. $\mathrm{O}$ desenvolvimento do transporte aéreo no Brasil configurou diversos estudos sobre a aviação comercial, distribuindo e classificando geograficamente o transporte aéreo em segmentos, dentro os quais residem o internacional, o nacional e o regional.

Os órgãos de administração e fomento à aviação comercial utilizam a classificação do transporte aéreo realizada pela OACI (Organização da Aviação Civil Internacional) que divide a aviação em segmentos de acordo com as empresas que operam em determinados espaços, mediante também a distância, o fluxo de passageiros e os aeroportos 
que recebem e destinam voos. Assim, destaca-se que a nomenclatura utilizada neste trabalho transporte aéreo regional - baseia-se na classificação da aviação geral, condizente com todas as operações de aviação civil. Desta forma, aborda-se toda a atividade aérea de passageiros, com exceção de operações não-regulares e de serviços prestados por táxi-aéreo. Sendo assim, a aviação civil divide-se em três níveis:

- Aviação de $1^{\circ}$ nível: É aquela empregada no serviço aéreo internacional;

- Aviação de $2^{\circ}$ nível: É aquela empregada no serviço aéreo doméstico;

- Aviação de $3^{\circ}$ nível: É aquela empregada no serviço aéreo regional.

A análise processada nesta pesquisa orienta-se mediante os critérios e classificações dos órgãos de gestão do setor de transporte aéreo. No entanto, é importante destacar que o termo "transporte aéreo regional" caracteriza-se como aquele que interliga centros pequenos e médios a centros urbanos maiores e/ou as capitais estaduais (BNDES, 2002) e, ainda, é considerado como aquele que interconecta as cidades do interior ${ }^{6}$, estabelecendo as relações sociais e econômicas nos territórios, as interações espaciais, bem como a constituição de uma rede de cidades hierarquizadas de acordo com o nível de especialização produtiva de cada centro urbano.

O transporte aéreo regional ramifica-se a partir de pólos definidos por meio da demanda pelo modal, orientando assim os nós de conexão e as redes de transporte. Desta forma, o segmento regional realiza a função de "alimentação" das linhas principais do sistema aéreo.

Em 1991, de acordo com a legislação aeronáutica, ocorreu o desmembrado do segmento nacional e regional. Segundo Barat (2008), as grandes transformações institucionais que pautaram a aviação civil na década de 1990 aboliram a delimitação de áreas para a exploração exclusiva das empresas de transporte aéreo regional, permitindo a concorrência direta entre empresas de âmbito nacional e regional. Contudo, se juridicamente a distinção entre empresas de transporte aéreo regional e de transporte aéreo nacional deixou de existir, a extinção desse conceito ainda vigora em termos práticos; o transporte aéreo regional continua operando em linhas de baixa densidade de tráfego, correspondendo a uma complementação do transporte aéreo de âmbito nacional e por vezes de âmbito internacional.

\footnotetext{
${ }^{6}$ Ao tratar a caracterização do "transporte aéreo regional" referenciada pelo BNDES faz-se referencia também ao litoral, ainda que não possua aeroportos regulares. Todavia, esta pesquisa ao tratar da multiplicidade dos fluxos aéreos, bem como da valorização espacial do interior paulista, refere-se, especificamente, as cidades do interior com aeroportos regulares, sendo que o litoral do Estado de São Paulo não apresenta aeroportos dessa finalidade.
} 
A caracterização da nomenclatura repousa sobre uma questão mais urbana do que institucional, ou seja, o transporte aéreo brasileiro está inserido em uma rede hierárquica de cidades que incontestavelmente subdivide o setor de transporte aéreo. De acordo com Barat (2008) a sistematização do planejamento de linhas e rotas é constituída em razão da própria hierarquia do sistema de cidades e da rede de aeroportos, bem como da evolução tecnológica e da concepção das aeronaves, da capacidade, da velocidade e da necessidade de apoio das infraestruturas aeroportuárias e aeronáuticas.

Dentro deste contexto, enfocamos que o presente trabalho aborda o modal aéreo a partir da conceituação geográfica sobre termos que focam a análise dos transportes, como, por exemplo: sistema capitalista, mobilidade, circulação, sistemas de movimento, infraestrutura, contiguidade, velocidade, técnicas, tecnologia, conexão, nós, linhas, redes, estratégias competitivas, combinações geográficas, formação territorial etc.

\subsection{A mundialização do capital, o meio técnico-científico-informacional e as revoluções e evoluções logísticas}

Na lógica do capital, a circulação é o vetor fundamental do processo social e econômico e os territórios são desse modo equipados para facilitar a mobilidade espacial necessária à economia mundial dos fluxos. O modo capitalista de produção requer e para isso fomenta formas baratas e rápidas de comunicação e transporte (HARVEY, 2006).

Para Santos e Silveira (2004), nos últimos decênios, o território conheceu grandes mudanças em função de acréscimos técnicos que renovaram a sua materialidade, e esse acréscimo tem origem no processo resultante da constituição do meio técnico-científicoinformacional que define um novo meio geográfico.

Com o desenvolvimento do capitalismo ocorreram mudanças substanciais na ordem econômica brasileira dos últimos anos, promovendo um processo de introdução do país na chamada "ordem global", que determina as incorporações inerentes aos padrões tecnológicos de produção e consumo do capitalismo. Haesbaert (1998, p.14) diz que "o capitalismo se reordena, sobretudo em função das constantes inovações tecnológicas, criando com elas 'necessidades' capazes de redirecionar e impulsionar novos ciclos produtivos".

Santos (2002) argumenta que, hoje, o capitalismo tem uma dimensão internacional e multinacional, mas, para isso, ele perdeu sua dimensão nacional. Nesse contexto, e como forma de encontrar uma correspondência a essa argumentação, torna-se crucial a análise acerca do que Chesnais (1996) chama de mundialização do capital, que tem 
permitido, entre outras vertentes, compreender o capitalismo em sua dinâmica mais relevante, ou seja, a da dialética da territorização e da mobilidade geográfica do capital ${ }^{7}$.

É nesse âmbito que tomamos a mundialização do capital como um processo resultante da interação entre a progressiva liberalização financeira e a crescente mobilidade dos capitais. Em outras palavras, acrescentamos que a mundialização do capital tem reestruturado o processo produtivo numa óptica que tem transformado a organização dos mercados mundiais na tendência, cada vez mais pragmática, de inserção marginalizada do centro com a periferia.

A análise desse trabalho preocupa-se com o enfoque do conteúdo tecnológico que o capitalismo e a globalização econômica impõem aos territórios, conformando o espaço de acordo com a internacionalização promovida pelo meio técnico-científico-informacional. Convém-nos explorar a mundialização do capital como um fator do ciclo de reprodução do capitalismo, ou seja, o período em si e suas variáveis características que se instalam em toda parte e a tudo influenciam. Nessa lógica, a mundialização do capital é tomada como um fator de promoção e imposição das inovações tecnológicas globais, assim como dos fluxos de pessoas, de mercadorias, de capital e de informações.

Chesnais (1996), ao considerar a conceituação do termo "mundialização do capital", alega que este tem, de fato, o efeito de diminuir, ao menos um pouco, a falta de nitidez conceitual dos termos "global" e "globalização". Nesse sentido, os termos "mundialização do capital" (CHESNAIS, 1996) e "globalização econômica" (GONÇALVES, 2003) são tomados, neste trabalho, como termos conceituais predominantes e equivalentes, devido, sobretudo, ao fato de esta ser a nomenclatura mais usual para o âmbito das mudanças e evoluções econômico-tecnológicas, identificando, de acordo com Silveira (2009), o processo de internacionalização do mundo capitalista a partir da evolução dos sistemas de movimento.

Assim, a ênfase baseia-se no processo resultante da globalização econômica para o Brasil, tendo como parâmetro o setor de transporte aéreo. Para Sassen (1998), a globalização econômica é uma questão de escala e de ampliada complexidade. Nesse sentido,

\footnotetext{
7 O termo "mobilidade geográfica do capital" compreende um campo de análise em que as conceituações e discussões permeiam diversas e conflitantes abordagens. Dentre os estudiosos que trataram a questão destacamos Adam Smith (1983), para quem o termo estava relacionado ao processo de funcionamento do sistema capitalista de produção. David Ricardo (1985) articula o termo ao valor e à utilidade do produto, o que gera a acumulação de capital. Karl Marx (1970) refere-se ao termo "mobilidade geográfica do capital" associando-o a todo processo de produção das mercadorias, que está intrinsecamente relacionado à acumulação e reprodução do capital, ao processamento da mais-valia e à conformação dos ciclos de acumulação capitalista. Já Rosa Luxemburgo (1976) toma a concepção do termo mediante o problema da reprodução do capital, numa análise oposta a marxista.
} 
propõe-se uma contextualização da escala internacional sobreposta à escala nacional e, mais especificamente, ao regional, priorizando para tanto a evolução do transporte aéreo a partir do desenvolvimento do setor no âmbito global que influencia as diretrizes do setor no Brasil.

As transformações conjunturais (econômicas, sociais, territoriais e culturais) ocorridas numa escala mundial afetaram as econômicas globais, observadas principalmente a partir do final do século XX, com destaque para o novo padrão de acumulação capitalista; ou seja, a mundialização da lógica do capital forma o cenário de reestruturação do transporte aéreo mundial, impondo novas formas de produção, consumo e, principalmente, de fluidez territorial.

Para Benko (1996), todas as transformações que permeiam o processo produtivo, econômico e social são acompanhadas de mudanças multiformes nos modos de produção e de consumo e, a partir dessa lógica materialista, induz uma reestruturação espacial na sociedade. Nesse contexto, temos que o capitalismo redefiniu o conteúdo ideológico dos espaços e do estabelecimento de uma nova divisão social e espacial do trabalho, bem como da criação de novos espaços de produção e de consumo, que muitas vezes são tidos como excludentes no modo de produção capitalista. Conforme avançamos no tempo, cada vez mais nos é imposto assumir, enquanto padrão de vida, as transformações geradas pelas mudanças das relações de produção e de trabalho (SILVEIRA, 2009).

Nesse sentido, o advento da globalização econômica impôs de maneira mais latente a redefinição do meio geográfico, fomentando o aperfeiçoamento dos meios de transporte, sobretudo o aéreo, que passou a ser mais intensivamente utilizado, sendo incorporados a espaços periféricos, como no Brasil, na intenção de interconectá-lo ao sistema econômico global.

Para compreensão da evolução do meio geográfico, bem como da sociedade em âmbito econômico, social, territorial e cultural, temos duas conceituações que se complementam, embora compreendam fatos e fatores diferentes. Dessa forma, temos, primeiramente, Santos (2002), que divide em três etapas a história do meio geográfico: o meio natural, o meio técnico-científico e o meio técnico-científico-informacional.

Em outro âmbito, destaca-se Silveira (2009), que apresenta um contexto históricoevolutivo no qual aborda as cinco revoluções e evoluções logísticas, seus impactos sobre o território brasileiro e as necessidades básicas impostas pela evolução da sociedade. Para tanto, sua elucidação é norteada sob a óptica correspondente aos ciclos econômicos de Kondratieff ${ }^{8}$,

\footnotetext{
${ }^{8}$ Tolmasquim (1991) assevera que o conceito dos ciclos econômicos origina-se a partir da teoria de Nicolai D. Kondratieff que nos anos de 1920 dizia que a economia capitalista se desenvolvia em ciclos. Nesse sentido, os
} 
ou seja, a partir das variações ascendentes e recessivas dos ciclos econômicos. Sendo assim, suas ideias são contextualizadas a partir das transformações tecnológicas nos meios de transportes, nas vias, na gestão e organização do território, nas estratégias logísticas e no planejamento, orientadas, principalmente, a partir do desenvolvimento das formas de produção e no âmbito das relações comerciais.

Essa abordagem, da qual nos referenciamos, tem como evidência primeira que as evoluções e revoluções logísticas constituem-se a partir de várias determinações, que funcionam numa relação de causa-efeito, estando essas determinações relacionadas com as interações espaciais, com a integração territorial, à modernização tecnológica dos meios e vias de circulação e comunicação, ao aumento dos fluxos de pessoas, bens, mercadorias e serviços.

Para Santos (2002), as substituições são dadas por meios cada vez mais artificializados, ou seja, cada substituição é sempre mais instrumentalizada, mais tecnicamente especializada, a partir de invenções e inovações dos sistemas de objetos que são responsáveis pela produção ou pelos sistemas de ações, propriamente ditos.

O meio natural, condicionado por um conjunto de fatores, possibilitava ao homem constituir sua base material mediante aspectos naturais de sobrevivência. Santos (2002) adverte que esse meio natural era utilizado sem grandes transformações e que as técnicas e o trabalho se completavam com dádivas da natureza. Observa-se o estabelecimento de um meio no qual a técnica implicava formas simples de adaptação, no qual o homem usava a natureza para transformá-la nos condicionantes ao exercício da vida.

No meio técnico-científico, verifica-se a utilização dos objetos como ferramentas que incorporam ao espaço a artificialidade das formas, estabelecendo a substituição dos objetos naturais pelos objetos técnicos.

Os objetos técnicos (...) juntam à razão natural sua própria razão, uma lógica instrumental que desafia as lógicas naturais, criando, nos lugares atingidos, mistos ou híbridos conflitivos. Os objetos técnicos e o espaço maquinizado são locus de ações "superiores", graças à sua superposição triunfante às forças naturais (SANTOS, 2002, p. 237).

As condições que propiciaram a passagem do meio natural para o meio técnicocientífico-informacional incorporam uma maior articulação entre a tecnologia e a ciência. Os objetos mais proeminentes são elaborados a partir dos mandamentos da ciência e da tecnologia, e, quanto mais aperfeiçoados, norteiam as novas formas de produção e consumo,

ciclos de Kondratieff estão ordenados sob a caracterização do desenvolvimento econômico mundial, e correspondem as flutuações da atividade econômica intimamente relacionada ao processo de efetivação tecnológica. Os ciclos compreendem por volta de 50 anos, sendo dividido em aproximadamente 25 anos de fase ascendente e 25 anos de fase recessiva. 
que se servem de uma técnica informacional da qual hes vem o alto coeficiente de intencionalidade. Em outras palavras, isto significa que a transformação e utilização de novas tecnologias são intencionalmente inseridas na sociedade como forma de intensificar o padrão de produção, consumo, mobilidade territorial e circulação do capital.

O meio técnico-científico-informacional desenvolveu-se sob a emergência da estruturação do mercado, com a união entre a ciência e a técnica, a qual alguns autores definem como "tecnociência" e, nesse sentido, o mercado definiu e, simultaneamente foi definido pelas características de um processo global, tornando-se um mercado global. Os territórios nacionais se transformaram num espaço nacional da economia internacional (SANTOS, 2002) caracterizada como "globalização". Esta vem ao encontro desse meio geográfico e incorpora a materialidade tecnológica nos territórios, impulsionando a constante modernização das técnicas, sobretudo dos meios de circulação e comunicação.

É nesse contexto que a análise de Silveira (2009) vem somar na identificação e compreensão do meio técnico-científico-informacional. Para o autor, as revoluções possuem uma conotação específica e regem as mudanças territoriais a partir das inovações e das invenções tecnológicas no setor de transportes, comunicações e na expansão do comércio.

O conceito de "revolução", nesse caso, se soma ao de "logística" para expressar "um conjunto de transformações tecnológicas no setor de transportes e comunicações a ponto de ampliar as interações espaciais e mudar a ordem socioeconômica vigente". Assim, em cada revolução logística tanto as integrações territoriais quanto a divisão territorial do trabalho foram ampliadas. Novos espaços comerciais surgiram e especializaram-se, novas formas de produção foram disponibilizadas e as trocas culturais, consolidadas (SILVEIRA, 2009, p.14).

A partir desse contexto, Silveira (2009), baseado na crítica sobre a análise de Ake Anderson, identifica cinco revoluções logísticas, as quais são apresentadas configurando-se uma requalificação periódica dos acontecimentos. Para tanto, assevera-se que as revoluções logísticas foram causa e consequência das revoluções industriais e que, portanto, fomentaram invenções e inovações que, por sua vez, manifestavam as interações espaciais, proporcionando aos países uma fluidez capaz de integrá-los territorialmente.

$\mathrm{Na}$ identificação da periodização das revoluções logísticas apresentadas por Silveira (2009), destacam-se a localização, a época e as tecnologias das revoluções logísticas. Nessa perspectiva, o autor ainda considera cinco períodos caracterizados pelas transformações das técnicas, os quais são interpretados como: Primeira Revolução e Evolução Logística; Segunda Revolução e Evolução Logística; Terceira Revolução e Evolução Logística; Quarta Revolução e Evolução Logística; e Quinta Revolução e Evolução Logística. 
Na Primeira Revolução e Evolução Logística, o autor identifica nos sistemas de movimentos (fixos e meios) padrões de circulação rudimentares que acompanharam, temporal e espacialmente, a expansão do comércio. Nesse contexto, observam-se fixos tais como: caravanas, rotas comerciais, uso contínuo da tração animal combinada com o uso da roda etc.

Na Segunda Revolução e Evolução Logística, nota-se um período em que se desencadeou a expansão marítima que fomentou a descoberta de novos espaços para a consolidação territorial da Europa e para a confirmação das transações comerciais e financeiras. Esse período compreende sistemas de movimento com rotas comerciais e caravanas por terra, além de rotas marítimas, juntamente à evolução tecnológica dos navios intercontinentais.

A Terceira Revolução e Evolução Logística marcaram a primeira Revolução Industrial. Nesse contexto estão inseridas as transformações técnicas nos meios de produção, como forma de responder ao recente capitalismo industrial.

Ao final do século XIX, irradia a Quarta Revolução e Evolução Logística, baseadas, sobretudo, numa técnica substancialmente combinada com a ciência, a qual se correlaciona ao período que Santos (2002) chama de técnico-científico. Assim, a Quarta Revolução e Evolução Logística desdobram-se num contexto político econômico bélico, em que hegemonicamente despontam a Alemanha, os Estados Unidos e o Japão 9 .

A requalificação realizada por Silveira (2009) trás como imperativo da atualidade a Quinta Revolução e Evolução Logística que são referenciadas pelo autor como um período de maior integração comercial, no qual se combinam técnica, ciência e informação, consubstanciando o período técnico-científico-informacional. A Quinta Revolução Logística enquadra-se no contexto da terceira Revolução Industrial, no qual se observa os sistemas técnico, científico e informacional e, por conseguinte, inicia-se um novo estágio da economia mundial.

Nessa óptica, o autor destaca que a requalificação da visão clássica sobre as revoluções logísticas permitiu compreender uma temporalidade e espacialidade diferenciada, que o fez incluir mais uma revolução logística que "representa uma fase de refuncionalização de manter em uso as tecnologias que estão maduras e se estandartizando (só que com uma outra função) - das invenções e inovações da revolução logística" (SILVEIRA, 2009, p. 40).

É nessa perspectiva de requalificação periódica das revoluções e evoluções logísticas que destacamos a intensidade do uso das tecnologias, através de inovações, de

\footnotetext{
${ }^{9}$ Observa-se que são estes os países que inicialmente exploraram as atividades aéreas no Brasil nesse período.
} 
transportes (numa perspectiva cíclica - ciclos de Kondratieff - e tecnológica, como apregoava Schumpeter), a qual está inserida o processamento do transporte aéreo, que se caracteriza pela modernização, pela velocidade empreendida, pela maior utilização da tecnologia em sua materialização, seja em relação aos voos, seja em relação a comercialização das passagens aéreas e/ou ainda na implementação de modernos softwares que costumizam e ampliam a maior adesão ao setor de transporte aéreo.

Cabe destacar ainda o papel empreendido pelo transporte aéreo, que teve maior destaque no período caracterizado por Silveira (2009) como a Quinta Revolução e Evolução Logística. $\mathrm{O}$ autor destaca que são muitas as tecnologias que compõem esse período da velocidade e da informação. Entre essas novas tecnologias, citam-se os aviões de grande porte, como o AIRBUS A380, as infovias, as auto-estradas, a telemática, os trens de alta velocidade, a fibra ótica, a comunicação via satélite, entre outras.

Sucintamente, atribui-se ao enfoque de Silveira (2009) uma contribuição sobre o transporte aéreo, que é de suma importância para a análise das revoluções e evoluções logísticas, ou seja, a de que o transporte aéreo consolidou-se progressivamente na história do desenvolvimento dos transportes. O primeiro esboço de modelização de um projeto de "avião" foi desenvolvido no século XV, por Leonardo da Vinci. Posteriormente, as guerras européias, em especial a Primeira Guerra Mundial, serviram como palco de testes para o uso do avião como armamento, que foi mais intensivamente utilizado durante a Segunda Guerra Mundial e na Guerra Fria.

Os avanços tecnológicos relacionados à aviação configuraram um ambiente mais propício para utilização do avião, primeiramente para fins bélicos e estratégias militares e, posteriormente, como um eficaz meio de locomoção de pessoas e mercadorias.

Em síntese, cabe ressaltar que a breve combinação entre as conceituações de Santos (2002) sobre o desenvolvimento do meio geográfico e de Silveira (2009) sobre as revoluções e evoluções logísticas têm como objetivo enfocar a nuance entre as formas verificadas no desenvolvimento econômico, social, territorial e cultural da sociedade, sempre na tentativa de buscar abordar as principais contribuições dos autores. Nessa abordagem verificam-se as continuidades e descontinuidades históricas correlatas entre esses autores e é nesse sentido que se observa a importância da correlação das conceituações especificadas pelos mesmos. Embora se tratem de diferentes formas (todavia, complexamente correlatas), a essencialidade das combinações entre as abordagens reside na compreensão da importância das inovações e invenções tecnológicas para o desenvolvimento econômico e territorial, e mais especificamente, do setor de transporte aéreo. 


\subsection{O transporte aéreo no contexto da mundialização do capital}

A discussão sobre o processo de mundialização do capital com base no período técnico-científico-informacional e nas revoluções e evoluções logísticas e os resultados advindos desse processo, de fato foi e é um fenômeno que contribuiu para a compreensão do desenvolvimento dos transportes, principalmente ao considerar que o modal aéreo é a base do transporte moderno e, nesse sentido, é essencial para o desenvolvimento e a integração territorial. A aviação é hoje, como tem sido desde seus primórdios, instrumento e fruto do desenvolvimento de uma sociedade globalmente integrada (MONTEIRO, 2007).

Ao relacionar a globalização econômica com o desenvolvimento do transporte aéreo, Jesus (2005) afirma que tal tipo de transporte foi um dos modais mais significativos e, também, possibilitador da globalização, pois na medida em que viabilizava a integração espacial dos mercados e dos produtos, proporcionava a integração funcional de atividades econômicas dispersas no território nacional. Em outras palavras, isso significa que o transporte aéreo no Brasil favoreceu "a progressiva supressão do espaço pelo tempo" (HARVEY, 2006).

Intrinsecamente relacionado ao processo da globalização econômica, a mobilidade do transporte aéreo reflete a modernização do setor, resultado do meio técnicocientífico-informacional. As novas tecnologias transformaram os novos espaços técnicos. Os meios de transporte, no último século, sofreram significativas transformações tecnológicas, de grande impacto na concepção das cidades e do ambiente construído. A evolução tecnológica refletiu mudanças também no transporte para longas distâncias. O aumento do volume da produção de mercadorias foi o fator inicial para o desenvolvimento tecnológico dos transportes de carga; posteriormente, a necessidade de transportes mais velozes para o deslocamento de passageiros a longa distância impulsionou a incrementação do modal.

No transporte aéreo, o aperfeiçoamento e a modernização das frotas são qualitativa e quantitativamente essenciais para o desenvolvimento do setor, mediante a imposição acelerada da tecnologia, que requer formas e padrões mais velozes e intensos nos sistemas de circulação.

Estes sistemas de objetos, renovados e remodelados constantemente, possibilitam a fluidez material e imaterial, na medida em que transmitem valores ao transporte aéreo. Desta forma, os sistemas de objetos constituem as vias atmosféricas pelas quais se reproduzem as redes conectadas espacialmente, ou seja, mesmo estas redes sendo formas intangíveis, estas se processam como elos de conexão nos espaços onde acontecem as 
interligações dos territórios, inclusive aqueles descontínuos espacialmente (BARROSO CARAVACA, 1998).

Santos e Silveira (2004) afirmam que com a produção do meio técnico-científicoinformacional, os círculos de cooperação instalaram-se em um nível superior de complexidade e numa escala geográfica de ação bem mais ampla, com a produção de fixos mais especializados e tecnologicamente melhores equipados, como forma de impulsionar a circulação territorial e, simultaneamente, integrar a articulação da lógica capitalista. É nesse âmbito que a análise de Marx (1970) sobre a circulação parte da configuração da acumulação e reprodução do capital e, assim, tem como princípio uma contextualização geográfica da circulação, a qual possui funções específicas que são desempenhadas no circuito total da economia capitalista. Nessa concepção, Arroyo (2006) alega que a circulação é uma das bases de diferenciação geográfica, por isso o interesse e a disputa dos territórios pela maior fluidez. Para que os fluxos se perpetuem, é necessária a criação de fixos produtivos.

Mais do que economia ou capitalismo, a globalização econômica é composta de um novo padrão tecnológico, pautado na velocidade das ações no tempo. Dentro dessa lógica de velocidade da fluidez no sistema de movimentação movido pelos fluxos de informações, de pessoas e de mercadorias, é que o transporte aéreo confirma-se atualmente como modal operante na velocidade de execução, reduzindo o espaço em relação ao tempo de locomoção (HARVEY, 1992). A necessidade de administrar o espaço faz com que o transporte aéreo configure espacialmente a lógica da organização territorial e permite também emergir eixos de ligação aérea viabilizados pela sua capacidade de redução de tempo de deslocamento no espaço. Assim, constata-se que o transporte aéreo introduziu o método mais eficiente de transpor as barreiras impostas pelas longas distâncias e topografia difícil (OWEN, 1975).

No enfoque da mundialização do capital, o mercado, com suas exigências de competitividade, impõe um aumento da velocidade do tempo no espaço, isto é, da diminuição do espaço em relação ao tempo. Esse fenômeno é denominado por Santos (2005, p. 331) "racionalização do espaço". É nesse sentido que o autor compreende que a nova etapa do processo secular de racionalização está essencialmente articulada à emergência do meio técnico-científico-informacional, produzindo os espaços da racionalidade e assim constituindo o suporte material das principais ações globalizantes.

Nesse contexto de análise, ao considerar o Brasil, Silveira (2009) alega que o forte processo de reestruturação econômico brasileiro, resultado direto da mundialização do capital, traz grandes consequências para o país: 
Na década de 1990, quando há o estabelecimento da Quinta Revolução Logística, as consequências sobre o Brasil são grandes. Tal fato vincula-se ao advento das políticas globalizantes e de integração territorial em larga escala (internacional) através do aumento dos circuitos espaciais de produção (fluxos de bens materiais) e dos círculos de cooperação no espaço (fluxos não-materiais - dinheiro, informação etc.). Nesse contexto delineado, o Brasil passou a ser incorporado, cada vez mais, ao sistema produtivo mundial (SILVEIRA, 2009, p.38).

Relacionado a esse processo, o Brasil compõe sua estruturação econômica mediante aos fatos ocorridos mundialmente. E, em tal âmbito, se compreende as escalas de análise, como a interferência do global no Brasil convergindo em transformações territoriais processadas a partir da modernização tecnológica que se reflete no setor de transporte aéreo brasileiro e também no segmento regional.

O impacto atual da tecnociência e da globalização econômica reforça as diferenciações territoriais e, ainda, consubstancia a imposição da tecnologia. Para Santos (2002), o efeito desestruturador da tecnologia é tanto mais brutal quanto menos implicado estiver o país em relação às inovações técnicas precedentes. Esses efeitos são simultaneamente sociais, econômicos, políticos, culturais, morais, espaciais e geográficos, levando a uma reorganização técnica dos territórios, que são constantemente readaptados e requalificados às novas formas de produção e consumo das formas geograficamente móveis, como é o modal.

A incorporação das inovações tecnológicas globais aos territórios confirma a concretização do processo globalizante. Esse processo contraria algumas imposições, mas revela o estado de modernização e adequação ao sistema vigente, ou seja, ao capitalismo moderno e às suas imposições tecnologicamente adequáveis. Dentro dessa lógica, compreende-se o desenvolvimento do transporte aéreo mediante a intensa reestruturação do setor às progressivas transformações tecnológicas. Observa-se constantemente a sobrevalorização da modernização dos equipamentos relacionados à operacionalização das companhias aéreas, a substituição de aeronaves obsoletas por aeronaves modernas, mais velozes e com maior espaço interno, com maior quantidade de assentos e, ainda, o acompanhamento dos sistemas de software específicos para a venda de passagens pela internet, em terminais eletrônicos e ainda por telefone (FRIEDMAN, 2005). Essas são características contundentes da maior especialização produtiva do setor.

Entende-se, nesse contexto, que o processo de mundialização do capital, acelerado com o desenvolvimento contraditório do capitalismo, estabeleceu um conjunto de normas que redunda na fundamentação de interesses globais. A ordem global busca impor, a todos os 
lugares, uma única racionalidade. E os lugares respondem ao mundo segundo os diversos modos de sua própria racionalidade (SANTOS, 2005).

Ao considerar o transporte aéreo e a base de seu desenvolvimento a partir da lógica capitalista e de sua nova estruturação consubstanciada no processo de globalização econômica, é imposta ao Brasil uma conjuntura técnico-científica que requer o constante aperfeiçoamento das técnicas e das normas estabelecidas nos grandes centros globais. Exemplo disso refere-se à normatização do processo de regulamentação ocorrido nos Estados Unidos e de extrema influência em outros países, como, principalmente, no Brasil. Dentro dessa lógica de influência, percebe-se que os espaços requalificados atendem aos interesses dos atores hegemônicos sintagmáticos (RAFFESTIN, 1993) e são incorporados plenamente às novas correntes mundiais. O meio técnico-científico-informacional é a cara geográfica da globalização (SANTOS, 2002).

A análise comparativa do transporte aéreo nos Estados Unidos busca contextualizar o desenvolvimento do setor no Brasil e no mundo, principalmente devido ao fato de ter sido o país no qual mais se confirmaram a normatização e as estratégias para o direcionamento do setor aéreo em âmbito global. Desta forma, não pretendemos, neste trabalho, desvincular o desenvolvimento do transporte aéreo em demais países, mas sim compreender o processo de estruturação atual do setor aéreo brasileiro, influenciado pelos acontecimentos ocorridos nos Estados Unidos, que, ultimamente, projetaram-se como eventos de caráter global e de influência mundial.

Os Estados Unidos lideram a oligopolização no setor de transporte aéreo, sendo suas ações incorporadas mundialmente. Na década de 1970, o novo paradigma tecnológico, organizado com base na tecnologia da informação, constituiu nos Estados Unidos um segmento específico da sociedade norte-americana em interação com a economia global e a geopolítica mundial, que concretizou um novo estilo de produção, comunicação, gerenciamento e vida que rapidamente se propagou por diferentes países. As novas tecnologias explodiram em todos os tipos de aplicações e usos que, por sua vez, produziram inovações tecnológicas, acelerando a velocidade e ampliando o escopo das transformações tecnológicas, bem como a diversificação de suas fontes (CASTELLS, 2001).

Benko (1996), ao analisar as transições da economia mundial na década de 1970, utiliza os ciclos de Kondratieff como uma das formas para se interpretar o desenvolvimento do capitalismo nesse período, bem como da intensificação da tecnologia no cotidiano da sociedade. Para isso, o autor utiliza-se de uma correlação com outros autores, argumentando que o conjunto de inovações radicais constituiu elemento endógeno no processo das ondas 
longas. Assim, alega que o novo paradigma tecnológico incorporado pelos Estados Unidos a partir da década de 1970 processou-se em razão de todo processo econômico vigente naquele momento e, também, em decorrência da crise do petróleo e resultado do ciclo econômico de Kondratieff, que refletiu uma nova fase no processo de reprodução capitalista, seguido mundialmente por diversas economias.

De acordo com o processo cronológico dos ciclos de Kondratieff, é possível perceber que a fase ascendente do Quarto Kondratieff, chamado de "30 anos gloriosos", impôs mundialmente os Estados Unidos como potência econômica e o estabelecimento de uma nova ordem mundial. A fase depressiva, reconhecida como uma fase de recessão mundial trouxe aos Estados Unidos o esforço de um novo ritmo de crescimento econômico, que contribui para revitalizar ainda mais o país na ordem econômica mundial.

Caracteristicamente marcada pela crise do petróleo, a fase recessiva do Quarto Kondratieff ocasionou aos Estados Unidos o aumento dos fundos bancários, que favoreceram a maior dependência dos países considerados do "Terceiro Mundo", incluindo o Brasil. A dependência econômica repercutia-se de forma setorial, principalmente em relação ao desenvolvimento do setor de transporte aéreo. Tal fato favoreceu a influência norteamericana, sobretudo em países como o Brasil. Assim, diversos setores da economia brasileira aderiram às novas configurações setoriais dos Estados Unidos, como, por exemplo, o setor aéreo brasileiro.

Nesse momento, a incorporação de ações de cunho neoliberal repercutiu mundialmente, com maior destaque para os países constituintes da América Latina, incentivando uma nova fase para o setor de transporte aéreo. Isso significa que a reestruturação do setor nos Estados Unidos processou-se a partir da desregulamentação político-econômica, que também influenciou a economia e a política brasileiras.

Assim, este capítulo tem como objetivo discorrer sobre o desenvolvimento e a evolução do setor de transporte aéreo no Brasil, correlacionando, quando necessário, os eventos ocorridos mundialmente, em especial nos Estados Unidos, que influenciaram, orientaram e reestruturaram o transporte aéreo brasileiro mediante o sistema capitalista.

No tocante a tal fato, observa-se que o Brasil proporciona condições totalmente favoráveis para o crescimento e desenvolvimento do setor aéreo, ora em razão de sua extensão territorial, ora em razão do crescimento das companhias aéreas brasileiras e, também, em razão do país apresentar uma rede de cidades que favorecem as escalas e conexões aéreas. Sua trajetória tem demonstrado períodos de ascensão e de crises, coerentes com as fases de auge e as fases recessivas dos ciclos econômicos, tanto internos como externos. O setor aéreo 
demonstra sua evolução a partir de um processo histórico que revela a atuação política na regulamentação e desregulamentação do setor, que propiciaram transformações inerentes à evolução do transporte aéreo brasileiro e regional paulista.

\subsection{Gênese e desenvolvimento do transporte aéreo brasileiro}

O transporte aéreo comercial desenvolveu-se, em todo o mundo com o término da Primeira Guerra Mundial, num momento em que se aproveitou o desenvolvimento da tecnologia aeronáutica e a quantidade da produção de aeronaves disponíveis no mercado (GARÓFALO, 1982).

Nesse momento, cabe identificar a diferenciação do transporte para fins militar e civil. O transporte aéreo é dividido em dois ramos da aviação, por assim dizer: um com determinações militares de segurança e controle nacional e outro com especificações comerciais, podendo, portanto, exercer atividades com fins lucrativos.

Marques (2005) define os ramos do sistema de navegação aérea alegando que se subdividem na aeronáutica civil e na aeronáutica militar. A primeira é de cunho público ou privado e desenvolve-se em aviação geral comercial, isto é, voos não regulares: fretamentos, atividades aerodesportivas, serviços aéreos especializados etc.; ou, ainda, aviação comercial regular associada a um sistema formado por empresas regulares com permissão na operacionalização de voos. Já a aeronáutica militar tem por destinação a produção da segurança; todavia, pode atuar na manutenção do controle de voos, na assistência às populações carentes, na construção de aeroportos e no transporte de autoridades.

Assim, destaca-se que nesse trabalho é abordado o transporte aéreo civil com fins comerciais para o transporte de passageiros. Nesse âmbito, a contextualização histórica do desenvolvimento do transporte aéreo aqui apresentado, seja em domínio global, nacional ou regional, concerne aos determinantes da aviação comercial regular.

Fouquet (2008), ao analisar a história das empresas de transporte aéreo regular brasileiro, relata que após o histórico voo de Alberto Santos Dumont com seu 14-Bis, em 23 de outubro de 1906, foram necessários mais de 12 anos até que o avião passasse a ser efetivamente usado como meio de transporte público. Isto ocorreu logo após o término da Primeira Guerra Mundial, quando, em 5 fevereiro de 1919, a empresa alemã Deutsche LuftReederei iniciou um serviço diário entre Berlim e Weimar, para transporte comercial de passageiros, carga e correio.

Nesse contexto, em pouco tempo foram criadas companhias aéreas também na França, na Grã Bretanha e em outros países, e a malha aérea foi continuamente expandida. A 
primeira empresa da América do Sul, a Scadta (atual Avianca), também foi fundada naquele ano, mas iniciou as operações regulares somente em 19 de setembro de 1921. No entanto, o Brasil, cujas características geográficas favoreciam o transporte aéreo, só veio conhecer suas enormes vantagens anos mais tarde (FOUQUET, 2008). Em tal âmbito, a apresentação do desenvolvimento da aviação comercial no Brasil é essencial como forma de representar historicamente os acontecimentos advindos da transformação e utilização de um novo modal que contribuiu, juntamente com demais meios de transporte, para a integração territorial do país. Eis os primórdios da aviação comercial brasileira.

\subsubsection{Dos primórdios da aviação comercial aos Sistemas Integrados de Transporte Aéreo Regional (1910 - 1980)}

O desenvolvimento do transporte aéreo brasileiro data suas primeiras atividades na década de 1910, com a criação da Escola Brasileira de Aviação, no Rio de Janeiro, e da Escola de Aviação da Força Pública, na cidade de São Paulo, que proporcionaram os primeiros cursos de pilotagem no país. Estas escolas foram criadas na perspectiva das políticas estatais que buscavam promover o desenvolvimento brasileiro mediante a integração geopolítica do território nacional através da consolidação de suas fronteiras nacionais $\left(\right.$ GALLO, 2006) ${ }^{10}$. Para Anderson (1979, p. 13) “o transporte aéreo desempenhou o papel de aberturas temporariamente solucionáveis ao processo de desenvolvimento".

A função preenchida pelas linhas de transporte aéreo, naquele momento, num país de grande superfície territorial, com núcleos humanos dispersos, evidenciou-se como essencial, especialmente para seu encargo específico, que é o transporte de passageiros (CARVALHO, 1963). Para Garófalo (1982), o início do desenvolvimento do transporte aéreo no Brasil representou perfeitamente seu caráter regional, na medida em que interligava centros regionais do país.

Nesse primeiro momento, de caracterização do transporte aéreo no Brasil, convém assinalar que, em 1926, já se empreendia a tentativa de projetar um plano nacional de transportes que, embora não priorizasse o modal aéreo, incluía-o no plano geral dos transportes. O engenheiro Pandiá Calógeras iniciou diversos trabalhos sobre os meios de transportes no país, incluindo o modal aéreo. No entanto, a busca pelas interligações territoriais tinha como principal aspecto o desenvolvimento das ferrovias (PLANOS DE VIAÇÃO, 1973).

\footnotetext{
10 Neste momento as redes geográficas do transporte aéreo já começavam a ser definidas, tendo as cidades do Rio de Janeiro e São Paulo como importantes nós do setor aéreo brasileiro.
} 
Nos primeiros anos de desenvolvimento do transporte aéreo o Governo liberou o setor à exploração da iniciativa privada estrangeira. De acordo com Jesus (2005), os primeiros estudos para a implantação de uma rota aérea no Brasil foram realizados em 1924 pela empresa aérea francesa Aéropostale ${ }^{11}$. Em 1927 o Governo liberou a exploração dos serviços de transporte aéreo à empresa Kondor Syndikat ${ }^{12}$ (alemã), posteriormente com o nome de Sindicato Condor que, anos mais tarde, transformar-se-ia na empresa aérea Serviços Aéreos Cruzeiro do Sul, e ainda para algumas empresas americanas, como, por exemplo, a $N Y R B A^{13}$.

Em seu ensaio sobre o transporte aéreo no Brasil, Almeida (1952) diz que o transporte aéreo foi, desde seu início, utilizado como fim comercial, atraindo a iniciativa privada estrangeira em sua exploração:

Em sua primeira fase a aviação comercial brasileira esteve fortemente vinculada a grandes empresas alemãs, francesas e americanas que disputavam a hegemonia do transporte aéreo na América do Sul. O lucro na exploração comercial não era o principal objetivo, pois as empresas então existentes procuravam expandir os serviços aeronáuticos de seus países, mantendo assim o prestígio de suas bandeiras e, principalmente, criando um mercado novo para suas indústrias de construções aeronáuticas e uma escola para o treinamento permanente de tripulação (ALMEIDA, 1952, p. 237).

As atividades aéreas, nesse momento, compreendiam o transporte de malas postais e autoridades e restringia-se aos trechos costeiros. Essa fase do transporte aéreo brasileiro marcou o início da história do Correio Aéreo Nacional ${ }^{14}$.

Nesse âmbito, a cronologia da aviação comercial brasileira foi inicialmente marcada pela concorrência no setor por empresas estrangeiras. Para Anderson (1979, p. 40), “a história de competição entre os Estados Unidos, a Alemanha e a França tinha como objetivo influenciar os serviços aéreos em desenvolvimento no Brasil” e, ainda, vislumbrava definir algumas expectativas das empresas estrangeiras, dentre as quais se destacavam:

i) Alimentar linhas aéreas internacionais (no caso dos Estados Unidos);

\footnotetext{
${ }^{11}$ A Aéropostale operou entre 1927 e 1931, transportando mala postal por rotas litorâneas entre Natal e Pelotas (COELHO, 2003).

${ }^{12}$ O Sindicato Condor atuou em âmbito nacional operando a linha da costa litorânea e, também, procurando abrir novas rotas rumo ao interior do país, mais especificamente através do Mato Grosso, chegando a Cuiabá, Corumbá e Rio Branco - cidades bastante isoladas na época. Esta empresa operou sem maiores problemas até o início da Segunda Guerra Mundial. Com o estado de guerra, transferiu seu controle acionário para brasileiros, sendo os diretores alemães substituídos por aviadores militares brasileiros (COELHO, 2005).

${ }^{13}$ A designação da sigla NYRBA referia-se a New York, Rio de Janeiro e Buenos Aires.

${ }^{14}$ Com o nome inicial de Serviço Aéreo Postal Militar, os serviços postais das duas forças existentes em 1930, do Exército e da Marinha, consolidaram-se passando a ser denominado Correio Aéreo Militar (CAM). Posteriormente, foi transformado no Correio Aéreo Nacional (CAN), sendo desativado em 1990 (ROCHA 2006).
} 
ii) Fortalecer os laços com uma comunidade de compatriotas residentes no Brasil (o caso alemão, onde a parte Sul do país, particularmente o Rio Grande do Sul, tinha atraído grandes povoados de imigrantes);

iii) Assegurar um mercado local para as aeronaves e equipamentos (uma motivação para os três países) e;

iv) Assegurar um aliado, bases para espionagem, reabastecimento etc. (provavelmente o caso da Alemanha dos anos 1920 e cada vez mais o caso dos Estados Unidos nos finais dos anos 1930 e começo dos anos 1940).

A presença, principalmente norte-americana e alemã, intensificava-se no Brasil (os Estados Unidos, através da Panair do Brasi1 ${ }^{15}$, e a Alemanha através da Kondor Syndikat). As empresas expandiram suas rotas e começaram um processo acelerado de concentração da malha de voos.

Em 22 de outubro de 1929, foi fundada no Rio de Janeiro, como subsidiária da companhia aérea norte-americana $N Y R B A$, a $N Y R B A$ do Brasil S. A.. Com bimotores anfíbios Sikorsky S-38, iniciou suas operações regulares em 24 de janeiro de 1930, transportando malas postais na linha Rio de Janeiro-Fortaleza. Alguns meses depois, a NYRBA foi absorvida pela empresa de bandeira americana Pan American Airways. Consequentemente, em outubro de 1930, a subsidiária brasileira adotou o nome Panair do Brasil S. A.. Os Estados Unidos almejavam planejar suas linhas para a Argentina, sendo uma pelo Oceano Pacífico e a outra linha, pelo Oceano Atlântico. O Brasil fazia parte da estratégica norteamericana em expandir suas linhas na América do Sul (FOUQUET, 2008).

Já a influência alemã resultou das consequências da Primeira Guerra Mundial. A Alemanha, impedida de executar voos em vários países europeus, criou uma empresa de produção e operação aérea, a Kondor Syndikat, pretendendo, por meio dessa organização, criar empresas em áreas consideradas neutras para os alemães, entre elas o Brasil. Fouquet (2008) avalia a história da empresa no Brasil salientando que a mesma iniciou suas operações no país mediante ações previamente estudadas pelos alemães:

Uma missão comercial encabeçada pelo ex-chanceler da Alemanha, Dr. Hans Luther, que teve por objetivo, entre outros, demonstrar a viabilidade do transporte aéreo, viajou da Argentina para o Brasil a bordo de um aerobote bimotor, do tipo Dornier "Wal". Denominado "Atlântico", pertencia ao

\footnotetext{
${ }^{15}$ A atuação norte-americana na aviação civil comercial brasileira inicia com a entrada no setor da empresa NYRBA Line. A NYRBA Line, sem condições de viabilidade financeira para executar voos e concorrer com as empresas nacionais e internacionais, foi absorvida pela Pan American World Airways, criando-se posteriormente, a Panair do Brasil. Esta chegou a ser considerada a oitava companhia aérea do mundo. Porém, em fevereiro de 1965, as suas autorizações de voos foram suspensas sem aviso prévio e sua falência decretada por ação do Governo, argumentando-se um colapso financeiro iminente (CASTRO e LAMY, 1993).
} 
"Kondor Syndikat", um consórcio de estudos controlado na época pela Luft Hansa. Em 01 de janeiro de 1927 o citado avião realizou um voo de apresentação do Rio até Florianópolis. Logo a seguir, o Kondor Syndikat (Berlim) recebeu autorização especial para estabelecer tráfego aéreo entre o Rio e pontos no Sul do país. O primeiro voo comercial foi executado em 03 de fevereiro de 1927 entre Porto Alegre-Pelotas-Rio Grande. Já em processo de liquidação, ainda estabeleceu serviços regulares entre o Rio e Porto Alegre (FOUQUET, 2008).

Cabe destacar que o transporte aéreo, como os demais modais, também contribui para integração econômica do país. Todavia, é importante considerar que essa contribuição não ocorreu na mesma intensidade pelos diferentes meios de transportes. Algumas regiões do Brasil contaram com o desenvolvimento do transporte aéreo na interligação de regiões localizadas no interior dos Estados, sobretudo no Sudeste e, mais especificamente, o Estado de São Paulo (FOUQUET, 2008). Tal fato propiciou a formação das redes aéreas e também intensificou as interações espaciais em territórios centrais do país, como em São Paulo.

Garófalo (1982), ao analisar historicamente a aviação comercial no Brasil, relata que a década de 1930 caracterizou a interiorização do transporte aéreo no país:

As ligações aéreas existentes pelo interior do país constituíam, em muitos casos, autênticas operações de desbravamento e penetração. Comercialmente eram exploradas, no geral, pelas companhias aéreas que guardavam vinculações estrangeiras e graças ao recebimento, pelas mesmas, de subvenções governamentais (...), entre essas empresas encontravam-se a Panair do Brasil e o Sindicato Condor (GARÓFALO, 1982, p. 31).

Todavia, mediante a exploração estrangeira, o Brasil reorganizou o setor no intuito de desenvolver nacionalmente a indústria da aviação no país e garantir a contiguidade do seu desenvolvimento aéreo. Para isso, criou, na década de 1930, o Departamento de Aeronáutica Civil, que anos depois foi transferido para o Ministério da Aeronáutica, passando a denominar-se Departamento da Aviação Civil (DAC). A criação desse órgão acentuava a intenção do Governo em expandir a aviação comercial no Brasil (FOUQUET, 2008).

Criado pelo Decreto 19.902, de 22 de abril de 1931, o DAC passou a ter os poderes relativos à regulamentação do setor aéreo brasileiro, tanto na área econômica como na área de segurança. O DAC era o órgão regulador do setor de transporte aéreo doméstico e estava vinculado ao Ministério da Defesa. Tinha por atribuições principais, até o ano 1989:

(i) Legislar sobre o estabelecimento de frequências e novas rotas aéreas, domésticas e internacionais, que se iniciassem em pontos do território nacional;

(ii) Regular as concessões de operações de empresas aéreas domésticas e os critérios para cancelamento e suspensão das mesmas;

(iii) Determinar tarifas aplicáveis para cada ligação aérea. 
A instituição do DAC tinha como objetivo a consolidação das empresas aéreas com critérios estabelecidos e com estímulo ao equilíbrio do mercado, bem como garantia uma alternativa de controle estratégico do setor pelos militares (FOUQUET, 2008) ${ }^{16}$. A administração do DAC, naquele período, pretendia minimizar a competição prejudicial, o excesso de concorrência e garantir a permanência das companhias de bandeira nacional.

Este momento caracterizou, de fato, o início da aviação comercial no Brasil com a criação da Viação Aérea Rio-Grandense $(\mathrm{VARIG})^{17}$, que deu início à primeira linha aérea brasileira. A VARIG, fundada em 1927, inaugurou a primeira linha comercial regular no Brasil (Porto Alegre-Pelotas-Rio Grande), que ficou conhecida como "Rota da Lagoa", com o aerobote Dornier Wal “Atlântico”, da empresa Kondor Syndikat (MONTEIRO, 2007).

Em sua fase inicial, a VARIG enfrentou inúmeras dificuldades, superadas inclusive com o apoio do Governo do Estado, que se tornou acionista ao adquirir, em 1930, as ações do Kondor Syndikat. Assim, a empresa somente ultrapassou as fronteiras do Rio Grande do Sul em 1942, ao inaugurar sua primeira linha internacional, para Montevidéu (FOUQUET, 2008). Tal fato favoreceu o estabelecimento e a ampliação das redes geográficas para o transporte aéreo.

Monteiro (2007, p. 37), em seus estudos sobre a empresa VARIG, diz que:

A VARIG procurou se articular à dinâmica do desenvolvimento da economia brasileira, construiu sua trajetória, de pequena empresa a líder no mercado, através de estratégias que envolveram a constante articulação com o poder público. Ela foi bem sucedida num momento em que o Estado capitaneou o processo de desenvolvimento econômico do país, intensificando seu controle sobre o transporte aéreo.

Intensificando a atuação estatal no setor, em 1933, foi criada a Empresa de Viação Aérea São Paulo (VASP). A empresa foi fundada por funcionários do Estado de São Paulo, com permissão para atuar em todo o territorial nacional. Contudo, o surgimento da VASP deu início ao desenvolvimento do tráfego aéreo regional no interior de São Paulo, com a primeira linha de São Paulo-São José do Rio Preto, e no âmbito interestadual, com a linha São PauloUberaba, com escala em Ribeirão Preto. A VASP, em seus primórdios, possuía características nitidamente regionais e tinha dois objetivos: atender a demanda paulistana e interligar as cidades do interior à capital do Estado (GARÓFALO, 1982).

\footnotetext{
16 Os anos de existência do DAC, sem dúvida, garantiram o controle militar do setor de transporte aéreo.

17 A criação da mais antiga empresa aérea brasileira resultou da iniciativa de um ex-oficial da Aviação Real Prussiana, Otto Ernst Meyer, que recebeu o apoio decisivo de autoridades e lideranças empresariais do Rio Grande do Sul. Fundada em Porto Alegre em 07 de maio de 1927, o capital da "S.A. Empresa de Viação Aérea Rio Grandense" foi subscrito por centenas de acionistas, entre eles o "Kondor Syndikat" (MONTEIRO, 2007).
} 
No âmbito político e econômico, a criação da VASP teve respaldo do Governo do Estado de São Paulo que, naquele momento, incentivou a constituição da empresa, devido à magnitude dos fluxos e dos fixos que vinham sendo instalados na cidade de São Paulo, como, por exemplo, os aeroportos (THÉRY, 2003). Por conseguinte, compreende-se que a VASP contribuiu para a integração territorial com o interior do Estado, mediante o sistema de movimento da circulação aérea, que viabilizava a redução do espaço pelo tempo a partir de um novo modal: o aéreo.

A dinâmica econômica paulista era permeada por um contexto de intensas modificações na estrutura política e econômica com o incentivo à produção industrial, ainda que incipiente, mas que constituíram as bases do desenvolvimento urbano-industrial do Estado que, consequentemente, influiu na dinâmica do setor aéreo regional paulista e, também, no movimento circulatório do capital.

Anderson (1979) relata que o processo histórico da VASP confirmou o aumento da intervenção estatal, pois o Estado de São Paulo tornou-se o maior associado e a cidade de São Paulo ficou como acionista minoritária. Para o autor, a VASP era a única empresa pública que tinha como acionista o mais economicamente poderoso Estado da nação. Segundo Théry (2003), a VASP fez parte do patrimônio do Governo Estadual até 1990, momento em que foi privatizada e adquirida por Wagner Canhedo, que programou uma política de expansão e de abertura de linhas internacionais para a Europa, Estados Unidos e Ásia.

O crescimento da empresa se deu até o momento de sua primeira crise infraestrutural. Jesus (2005) alega que já em 1934 e ao longo de 1935, a companhia defrontou-se com algumas dificuldades de ordem técnica, especialmente a paralisação das atividades em Ribeirão Preto, devido às más condições da pista de pouso e a fortes chuvas na capital paulista, que também tornaram impraticáveis as operações no Campo de Marte, único campo de pouso disponível na cidade de São Paulo. De acordo com a autora, mediante as dificuldades da empresa, a VASP foi transformada em sociedade de capital misto, sendo privatizada nos anos de 1990.

Assim, a VASP representava um papel estratégico de participação estatal, reproduzindo a regulamentação no setor, o que garantiu o desenvolvimento do transporte aéreo no Estado de São Paulo, sobretudo em seu interior, intensificando as interações espaciais no Estado processadas pelo transporte aéreo.

Nesse sentido, é possível compreender que a década de 1930 marcou, mesmo que incipientemente, um período pioneiro no transporte aéreo comercial, com a criação de grandes empresas que, posteriormente, teriam amplitude nacional e, também, com a maior atuação do 
Governo na regulamentação do setor, incentivando e protegendo empresas de bandeiras nacionais.

No entanto, o grande impulso para o desenvolvimento do setor acentuou-se na década de 1940, em decorrência da quantidade de aeronaves excedentes de guerra que eram transportadas para o Brasil a baixos custos, fato que possibilitou a criação de várias companhias aéreas (GARÓFALO, 1982). Com o surgimento da VARIG e da VASP, nascia a aviação comercial de linha tipicamente regional, sem a preocupação de ligar grandes centros comerciais ou populosos. As empresas aproveitavam os aviões para suprir a deficiência ou a falta de outros meios de transportes, promovendo e intensificando as interações espaciais, sobretudo regionais.

Mediante esse processo, a influência alemã cessou após a Segunda Guerra Mundial, em decorrência da derrota da Alemanha. Em consequência, os Estados Unidos expandiram-se no setor aéreo brasileiro, passando a abastecer o Brasil com aviões e peças excedentes de guerra. Exemplos desses equipamentos foram os modelos DC-3 (Douglas), DC-4, PBY-5 (Catalina, também conhecido como Anfíbios) e C-47 ${ }^{18}$. De acordo com Anderson (1979) esta primeira leva de equipamentos aéreos marcou o primeiro estágio das gerações de aeronaves destinadas à aviação comercial no Brasil.

\footnotetext{
${ }^{18}$ Os modelos de aeronaves eram adquiridos pelo Brasil após as guerras. Os modelos DC-3, DC-4, Catalina e C47 eram aviões de motores de explosão não pressurizados produzidos em grande quantidade para as necessidades de transporte militar (ANDERSON, 1979).
} 


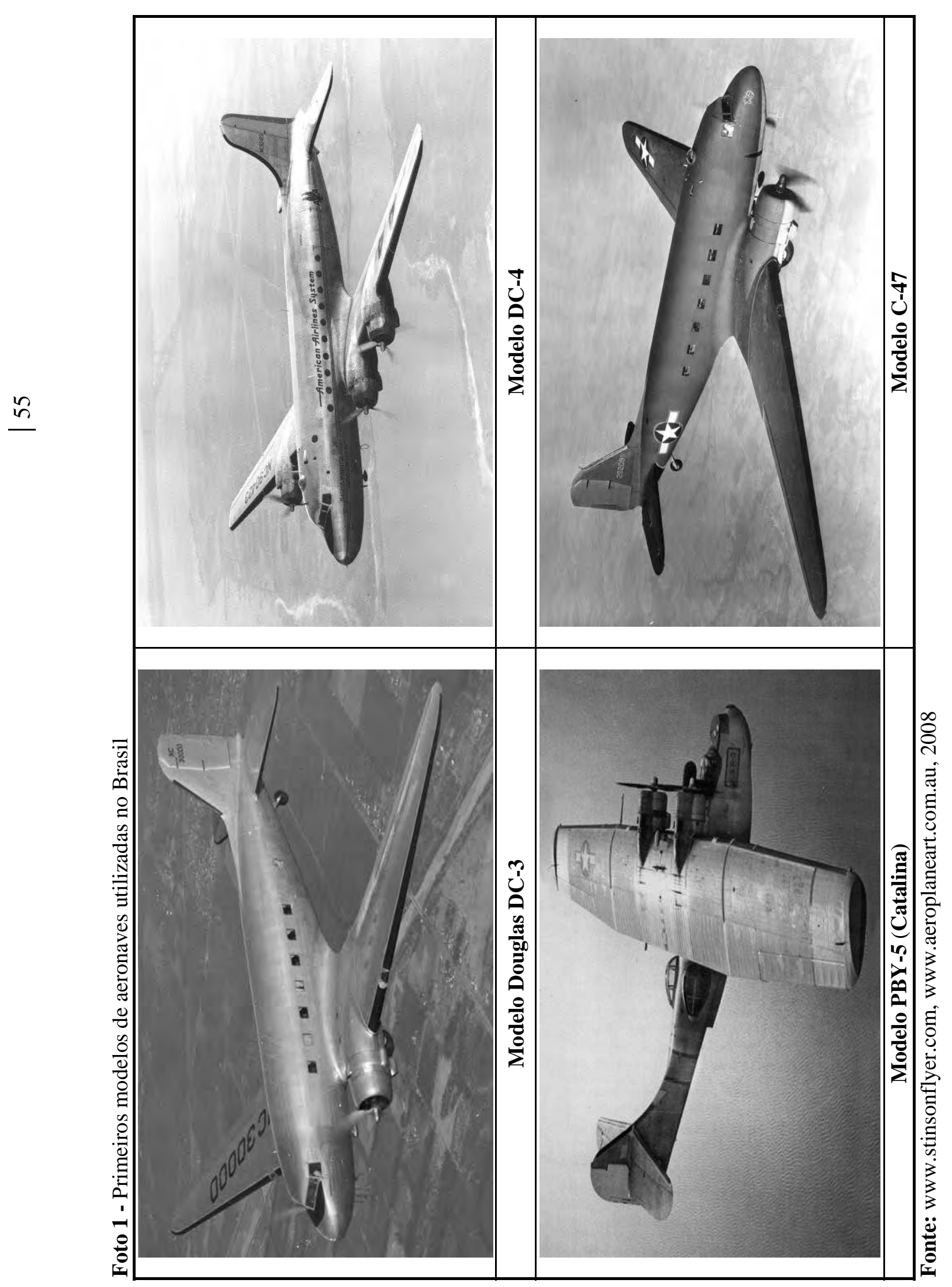


O DC-3 foi o principal modelo utilizado inicialmente no Brasil para linhas comerciais. Anderson (1979) enfatiza que nos países em desenvolvimento a disponibilidade de aeronaves excedentes de guerra, num valor reduzido, permitiu expandir largamente os sistemas de transporte aéreo. Com o tempo, as invenções de novas tecnologias de produção da indústria aeronáutica introduziram novos modelos de aeronaves com maior capacidade para o transporte de passageiros e maior velocidade nos deslocamentos, tornando o DC-3 um modelo antieconômico.

A modernização infraestrutural dos aeroportos também se caracterizou como requisito fundamental para o desenvolvimento aéreo no Brasil. Coelho (2003) alega que ocorreu uma reestruturação no setor, principalmente em relação à segurança dos passageiros e das cargas transportadas. Com a adequação dos aeroportos, as companhias aéreas passaram a investir maciçamente em equipamentos aéreos.

O desenvolvimento dos aeroportos também foi decisivo na evolução da aviação do pós-guerra. Além do crescimento do número de aeródromos ocorridos durante a Grande Guerra, estes apresentavam um novo padrão de infraestrutura importante para o incremento do tráfego aéreo. Em primeiro lugar, os novos aeroportos, com pistas de concreto, áreas amplas de escape, taxiamento e hangares estruturados foram decisivos para acabar com a importância dos aerobarcos e consolidar os serviços baseados em aeronaves convencionais. Em segundo lugar, os novos aeroportos foram projetados mais próximos das grandes cidades, o que tornou mais atrativa a alternativa do modal aéreo frente aos trens ou automóveis. Por fim, o crescente desenvolvimento em peso, tamanho, velocidade e aparatos de navegação das novas aeronaves tornaram imperativo o constante desenvolvimento, aprimoramento e expansão dos aeroportos (COELHO, 2003, p. 35).

Além dos avanços relativos à tecnologia dos equipamentos e às melhorias na infraestrutura, o Brasil desenvolvia sua legislação aérea como forma de potencializar as empresas aéreas de bandeiras nacionais, sempre baseadas em ações estrangeiras como as dos Estados Unidos. Anderson (1979) diz que a primeira legislação ao estabelecimento de rotas aéreas estipulou que aquelas que circulavam entre pontos do território nacional e as de tráfego internacional só poderiam ser estabelecidas e exploradas mediante concessão do Governo Federal, sem privilégio ou monopólio. A partir desse período, o setor passou para o controle estatal. Segundo Rocha (2005), este foi o início da fase de regulação intervencionista do Governo, que se incumbia da gestão setorial bem como da liberação de rotas, criação de 
companhias aéreas baseadas, sobretudo, no protecionismo, subsídios, subvenções com o intuito de integrar o país territorial e economicamente ${ }^{19}$.

Externamente à legislação brasileira, desenvolvia-se mundialmente a Convenção de Chicago, surgindo a Organização da Aviação Civil Internacional, que definiria os direitos que uma empresa aérea poderia gozar em espaço aéreo estrangeiro. Os Estados Unidos defendiam sua política de "Céus Abertos", ou seja, a liberalização total do espaço aéreo a livre concorrência. Mediante o pouco êxito da política de "Céus Abertos", o país continuou sua atuação no Brasil. Todavia, o setor aéreo brasileiro passou a ter o respaldo do Governo Federal, como forma de alavancar as companhias aéreas brasileiras e defender o setor da concorrência internacional.

Mediante o desenvolvimento do setor e o surgimento de duas grandes empresas VARIG e VASP - e a incorporação da empresa Sindicato Condor pela empresa Serviços Aéreos Cruzeiro do Sul, observa-se o surgimento de um grande número de companhias aéreas privadas, que segundo Rocha (2006) teve como consequência direta o excesso da oferta em relação à demanda, o que fez com que as atividades se tornassem antieconômicas. Com isso, praticamente todas as empresas enfraqueceram, faliram, fundiram-se ou foram absorvidas por outras empresas que suportaram a concorrência.

Nesse momento de criação de várias empresas aéreas no Brasil, é importante enfatizar a criação de três grandes empresas aéreas, que contribuíram sobremaneira para o desenvolvimento do setor aéreo. São elas: Serviços Aéreos Cruzeiro do Sul, - denominada, anos mais tarde, por Cruzeiro do Sul, - a Real S.A. Transportes Aéreos (Consórcio Real) e a Sadia S.A. Transportes Aéreos, posteriormente Transbrasil Linhas Aéreas.

Segundo Fouquet (2008), a empresa Sindicato Condor, - que adotara a denominação Serviços Aéreos Condor Ltda. - envolvida pelos acontecimentos da Segunda Guerra Mundial, sobretudo devido aos vínculos com a transportadora de bandeira alemã Lufthansa, foi nacionalizada. Permeada por um período particularmente difícil, que somente pôde ser superado com o apoio do Governo, naquele ano adotou, também, a denominação Serviços Aéreos Cruzeiro do Sul. A Cruzeiro entrou na década de 1970 com sua situação econômico-financeira debilitada. Após o fracasso de algumas tentativas que visavam à composição com outras operadoras em dificuldade, em 1975 o controle acionário da empresa foi vendido à Fundação Rubem Berta, detentora da maioria do capital da VARIG. As duas

\footnotetext{
${ }^{19}$ É importante observar que a integração territorial do Brasil foi dada pelo modal rodoviário. "As necessidades de um país continental como o Brasil, a busca pela rápida integração do território foi o objetivo mais lógico e o meio de transporte a realizar essa integração foi, especialmente, o rodoviário" (SILVEIRA, 2007, p. 33).
} 
empresas, então, integraram suas operações, tendo, porém, mantido a independência jurídica até a total incorporação da Cruzeiro pela VARIG, em fins de 1992 (ROCHA, 2005).

No que tange a Real S.A. Transportes Aéreos (Consórcio Real) ${ }^{20}$, a empresa foi fundada em São Paulo em fins de 1945 com o nome Redes Estaduais Aéreas, por um grupo liderado pelos comandantes Linneu Gomes e Vicente Mammana Neto. A Real começou a operar serviços regulares na linha Rio de Janeiro-São Paulo e, entre os anos de 1948 e 1951, absorveu três empresas menores, proporcionando acesso a outras regiões de São Paulo, além de Minas Gerais, Mato Grosso e o Nordeste. O crescimento da empresa foi obtido com a aquisição da Aerovias Brasil e sua associada, a Aeronorte, e, posteriormente na aglutinação com o Grupo Nacional. Em 1957, a Sadia S.A. Transporte Aéreo associou-se à Real. No ano de 1958, o Consórcio Real Aerovias Nacional havia se transformado na maior empresa aérea brasileira e sul-americana. Para Fouquet (2008), antigo funcionário da empresa, e quem nos revela o desenvolvimento da empresa, a falência da Real é explicada:

Pelo crescimento acelerado que esgotou os recursos da empresa. Altamente endividada pela compra de aviões a pistão - cuja obsolescência se acelerava ante a entrada em operação dos jatos - a Real viu-se forçada, num primeiro estágio, a transferir suas linhas internacionais à Aerovias Brasil, de cujo capital a VARIG então adquiriu 50\%. Assim mesmo a situação econômicofinanceira continuava insustentável, a VARIG, por recomendação do Governo, comprou todo o Consórcio Real em agosto de 1961. Sua incorporação definitiva foi consumada algum tempo depois (FOUQUET, 2008).

Em 5 de janeiro de 1955, a Sadia S.A. Transportes Aéreos ${ }^{21}$ iniciou suas atividades transportando produtos perecíveis da marca "Sadia", da cidade de Joaçaba/SC para São Paulo. O primeiro serviço regular com aviões de passageiros foi inaugurado em 16 de abril de 1956, na rota São Paulo-Joaçaba-Videira-Florianópolis. (FOUQUET, 2008). Em fins de 1957, quando suas linhas já alcançavam Brasília, Porto Alegre e o Rio de Janeiro, a Sadia firmou acordo de consórcio técnico-operativo com a empresa Real que vigorou até a absorção daquela companhia pela VARIG, em 1961. Operando de forma independente, a Sadia

\footnotetext{
${ }^{20}$ A Real iniciou suas operações na linha Rio de Janeiro-São Paulo. Consolidou-se mediante a criação de um sistema regional no Sul do país comprando empresas de pequeno porte. No final da década de 1950 e início da década de 1960, a empresa assina um acordo de formação da Real Aerovias Nacional, passando a condição de maior grupo de aviação civil no Brasil (GARÓFALO, 1982).

${ }^{21}$ A empresa Sadia Transportes Aéreos foi fundada por Omar Fontana, o filho do dono da Sadia. Inicialmente transportava carne fresca e linguiça de Santa Catarina a São Paulo. Em 1956, ele criou a Sadia Transportes Aéreos, para transportar mercadorias e passageiros no trecho Florianópolis, Videira, Joaçaba e São Paulo. Antes mesmo do final dos anos de 1980, já era a terceira empresa do país. Nesta época contava com 10 Boeings 727 100, chegando a abrir linhas internacionais para Miami, New York, Washington, Viena, Buenos Aires e Londres. Em 1998, o fundador deixou a direção da firma, falecendo no ano de 2000, pouco antes da queda final da companhia. "Sem fundos para pagar o combustível, a Transbrasil anulou todos os seus voos no dia 31 de dezembro de 2000, deixando 100.000 bilhetes de avião sem valor nas mãos de clientes da empresa (THÉRY, 2003, p.23)."
} 
adquiriu, em 1962, a empresa Transportes Aéreos Salvador. A Sadia, que posteriormente teria seu nome mudado para Transbrasil, foi a única sobrevivente dentre as empresas criadas entre os anos 1940 e 1950.

A consequência imediata do surgimento de um grande número de empresas foi a redução dos níveis de qualidade e segurança no setor. A necessidade de novamente reestruturar a frota aeroviária brasileira, que faz parte do processo de inovações tecnológicas e organizacionais, favoreceu ainda mais a diminuição do número de companhias aéreas que não tinham finanças suficientes para tal propósito. No final da década de 1950, segundo Rocha (2006) as grandes empresas do setor, tais como a VASP, VARIG, Real, Sadia, renovaram suas frotas, consagrando a "era da aviação a jatos".

Conjuntamente com a crise que se instaurava no setor aéreo, os anos de 1950 foram fortemente influenciados pela política de defesa ao rodoviarismo-automobilístico. Para Garófalo (1982), a década em questão marcou o início dos esforços do Governo Federal, estaduais e municipais, que procuravam dotar o Brasil de uma rede rodoviária adequada. Esses fatores influenciaram negativamente o setor de transporte aéreo brasileiro que, devido ao seu custo de mobilidade maior que o rodoviário, sofreu desajustes econômicos por causa da concorrência.

É importante enfatizar que esse período também foi influenciado pelo desenvolvimento de políticas estatais que visavam promover a integração política e econômica do Brasil. No ano de 1951, sob o comando de Eurico Gaspar Dutra e, posteriormente, de Getúlio Vargas, foi revisto e atualizado o Plano Nacional de Viação (PNV) do ano de 1946. A revisão do plano consistia na contribuição à sistematização da política de transporte no Brasil. No que tange ao setor aeroviário, o PNV de 1951 preocupou-se com o entrosamento do modal com os demais sistemas de transporte. Assim, nota-se que a função estratégica para o modal aéreo não estava circunscrita no desenvolvimento e propagação da utilização do modal pela sociedade, mas sim servir como um apêndice a demais modais, principalmente o rodoviário (SKIDMORE, 1982).

A partir da revisão do PNV em 1951, ocorreu a priorização do setor aéreo com fins comerciais, acentuando o tráfego aéreo de passageiros. Desta forma, funcionou como estímulo à aviação em geral, às empresas e ao fomento de investimentos em infraestruturas. Todavia, tal intento não fez com que a matriz de transporte rodoviário fosse substituída, continuando a se priorizar a construção de rodovias no Brasil e no Estado de São Paulo.

No âmbito político, a defesa de Getúlio Vargas sobrepunha-se na consolidação industrial do país, conferida juntamente com a defesa do desenvolvimento de rodovias e de 
investimentos nas infraestruturas relacionadas ao modal rodoviário, como forma de dispersar o consumo dos produtos nacionais no mercado interno. Baseado nessa perspectiva, Vargas procurava conduzir a tentativa de estabilização econômica do Brasil, uma vez que a alta nos preços do café havia aumentado a receita cambial brasileira (SKIDMORE, 1982). Do ponto de vista político e econômico do Governo brasileiro, não era interessante, naquele momento, investir no planejamento aéreo, em razão de que todo o projetamento setorial de transportes focalizava o modal rodoviário.

Os planos de Vargas foram mais intensivamente confirmados no Governo de Juscelino Kubitschek. Baseado no nacionalismo desenvolvimentista, Kubitschek propunha o "Plano de Metas", composto por um programa escalonado de investimentos públicos, dirigidos para a superação dos estrangulamentos estruturais, sobretudo nas áreas de transportes e produção de energia (SKIDMORE, 1982).

Mediante o desenvolvimento econômico brasileiro, o setor de transporte aéreo obtinha pouco favorecimento para seu crescimento, em razão das opções políticas do país, que incentivavam o rodoviarismo em contraponto aos demais modais. Em decorrência da ausência de investimentos e a fragilidade econômica que o transporte aéreo brasileiro convivia, acirrava-se a competição entre as companhias aéreas, intensificando o processo de falências e fusões das empresas.

De acordo com Castro e Lamy (1993), em 1950 havia no Brasil 22 empresas aéreas; em 1955, esse número reduziu-se para 14 empresas e, em 1960, eram 10 empresas que operavam voos no país, resultado do processo acelerado de falências e absorções das empresas e da concorrência com o setor rodoviário.

A década de 1960 representou para o transporte aéreo um período de decadência, devido, sobretudo, ao gradativo crescimento e ampliação da estruturação da malha rodoviária. Sobre este período, Anderson (1979) argumenta que a partir do início da década de 1960 a dependência do avião passou a declinar com o incremento da indústria automotriz e o programa de melhoramento de rodovias.

Na década de 1960, a aviação brasileira enfrentou momentos difíceis. Em 1961, a malha rodoviária já se encontrava estruturada nos seus grandes eixos, afetando a demanda por viagens aéreas nas ligações de curta distância, principalmente na região Sudeste, a mais disputada pelas companhias de aviação. Além disso, continuou existindo grande concorrência no setor, comprometendo a rentabilidade das empresas que necessitavam de novos investimentos para a renovação da frota, pois a manutenção daquelas aeronaves oriundas da guerra tornava-se cada vez mais difícil (BNDES II, 2002, p.1). 
O setor de transporte, como demais segmentos da economia, está intimamente correlacionado ao desempenho econômico do país. Na década de 1960, mais especificamente até os anos de 1965, o país passava por intensas crises conjunturais, consequências políticas, de desajustes econômicos e outros fatores correlatos. Com isso, o desenvolvimento do transporte aéreo sofreu um retrocesso que foi timidamente retomado a partir do final da década.

Tabela 1 - Passageiros transportados $(1962-1970)$

\begin{tabular}{c|c}
\hline Anos & Passageiros transportados \\
\hline 1962 & 3.935 .060 \\
\hline 1963 & 3.291 .777 \\
\hline 1964 & 2.406 .932 \\
\hline 1965 & 2.230 .027 \\
\hline 1966 & 2.335 .870 \\
\hline 1967 & 2.460 .463 \\
\hline 1968 & 2.632 .297 \\
\hline 1969 & 2.509 .347 \\
\hline 1970 & 2.603 .559
\end{tabular}

Fonte: Anuário do Transporte Aéreo (vários anos); GARÓFALO (1982)

Org.: Camilo Pereira, 2009

No período subsequente, ou seja, dos Governos militares, interrompeu-se o processo de tramitação do Plano Nacional de Viação, revisto em 1951. Orientou-se o planejamento de um projeto que partia de uma visão geopolítica construída em função da realidade econômica e espacial daquele período. De acordo com Skidmore (1982) o planejamento militar que incluía os transportes ficou conhecido como os "Planos Quinquenais", e foram mais efetivamente estabelecidos no Governo de Ernesto Geisel. Todavia, tal planejamento, como nos demais PNVs, priorizavam o modal rodoviário em detrimento dos demais.

Esse processo de descontinuidade histórica do planejamento do transporte aéreo e de sua consequente crise provocou uma diminuição das rotas regionais que eram comprometidas pela estrutura do mercado e pelo modal rival, isto é, o transporte rodoviário. Nesse período ocorreu a diminuição do tráfego aéreo regional. Silveira (2007) alega que a ampliação da teia rodoviária passou a eliminar as barreiras regionais, iniciando a formação de um mercado nacional com novos espaços comerciais para o capital industrial. A constituição de um território unificado se deu, portanto, pela rede rodoviária, na qual o autor considera como sendo a grande articuladora na rede urbana brasileira e, portanto, o meio de transporte que mais intensificou as interações espaciais. 
A aparente saída para a crise instalada veio com as Conferências Nacionais de Aviação Comercial (CONACs) ${ }^{22}$. Apesar das CONACs terem servido de orientações para o planejamento de políticas no setor aéreo, mediante a intervenção do Governo, marcaram, todavia, o início de um período de regulamentação do Governo. Assim, foram realizadas nos anos de 1961, 1963 e 1968 as conferências (I, II e II CONAC's, respectivamente), cujas deliberações conduziram um estímulo à redução do número das empresas e de um forte regime de controle por parte do Governo, que inicia a atuação intervencionista em todas as decisões ligadas ao setor. Assistia-se, nesse momento, a uma intensa regulamentação setorial (JESUS, 2005).

O encaminhamento político entre o Governo e as companhias resultou na diminuição do número de empresas no setor. O Governo passou a incentivar a fusão de empresas e implantou um regime de competição controlada. A ação federal, em conjunto com os Estados da Federação, passou, de fato, a regular o setor e as atividades das companhias aéreas num processo semelhante ao ocorrido nos Estados Unidos, no qual o Poder Público delegava ampla defesa ao setor doméstico.

Garófalo (1982) assevera que nesse momento de controle governamental acentuou-se o incentivo a fusão de empresas. A Panair do Brasil foi absorvida pela VARIG, que passou a controlar a Real Aerovias, que havia encerrado suas atividades devido à inviabilidade econômica apresentada pela empresa. A VASP agregou a seu patrimônio pequenas empresas do setor. Em 1962, a Sadia Transportes Aéreos assumiu o controle de uma empresa aérea que operava rotas na Bahia, passando a ser denominada, a partir de então, Transbrasil Linhas Aéreas.

No âmbito regional paulista, cabe destacar que, nesse período, houve uma redução das rotas de baixo e médio potencial de tráfego. As companhias aéreas mantinham seus interesses em rotas mais lucrativas, chamadas de "linhas troncos", isto é, rotas mais densas e de maior agregação de valor, tais como as nacionais e, principalmente, as internacionais, que se caracterizavam pela sua expressividade econômica.

$\mathrm{Na}$ tentativa de incentivar o transporte aéreo no interior do país e continuar o uso de aeronaves consideradas obsoletas pelo setor (Douglas DC-3, DC-4, PBY-5 Catalina etc.), o Governo lançou um programa de auxílio ao transporte aéreo regional, que ficou conhecido como Rede de Integração Nacional (RIN). O programa buscava incorporar regiões

\footnotetext{
22 "CONACs foram eventos organizados com a finalidade de discutir e alterar os rumos da regulação do transporte aéreo" (OLIVEIRA, 2009, p. 88).
} 
consideradas inóspitas do ponto de vista do isolamento territorial, como a região Amazônica (MARQUES, 2006).

O objetivo do RIN era manter a integração de algumas cidades desprovidas de outros meios de transportes. De acordo com Garófalo (1982):

A Rede de Integração Nacional acabaria abrangendo, praticamente, todas as ligações nacionais, exceto as linhas diretas entre capitais e, assim o fazendo, preservou aquelas ligações que, servindo às regiões remotas relativamente aos grandes centros do país, não ofereciam atrativos às companhias aéreas comerciais, dados estas não disporem de recursos suficientes para suportar os prejuízos operacionais daí advindos (GARÓFALO, 1982, p. 64).

Contudo, o insucesso do RIN ocorreu em razão, principalmente, das condições de tráfego não viáveis economicamente. Mesmo o Governo oferecendo subsídios orçamentários para as empresas realizarem as rotas no interior do país, a situação do setor regional tornavase cada vez mais precária e dependente. O desinteresse do Governo no prosseguimento do programa contribuiu ainda mais para sua extinção, intensificando o processo de aquisição e fusão dessas empresas regionais por empresas nacionais que apresentavam maior rentabilidade no setor e, com isso, consequentemente, reduziu-se o número de cidades servidas no interior do país, que passaram a não mais dispor do serviço aéreo regional (ROCHA, 2006).

A década de 1960 fecha um período de crise no setor, resultando em um processo de aniquilamento de empresas de pequeno e médio porte e concomitante do segmento regional, já que as empresas de pequeno e médio porte atendiam localidades interioranas. Com o início da década de 1970, restavam apenas quatro companhias aéreas: VARIG, Cruzeiro do Sul, VASP e Transbrasil (ANDERSON, 1979).

A diminuição do número de empresas que faliram ou fundiram-se a outras empresas, devido à ausência de investimentos para renovação de suas frotas, somada à constante modernização da produção estrangeira no ramo da indústria aeronáutica, incentivou a produção de uma tecnologia própria no Brasil, um processo de substituição de importações. Todavia, tal fato não aumentou o consumo dessa tecnologia pelas empresas brasileiras; exemplo disso ocorreu com a Empresa Brasileira de Aeronáutica (EMBRAER) ${ }^{23}$.

\footnotetext{
23 A EMBRAER foi criada no ano de 1969, como empresa de capital misto e com a finalidade de produzir aeronaves Bandeirantes em série. Foi privatizada em 1994 e seu controle está em mãos brasileiras sob controle do capital nacional. Além de abastecer o mercado regional, a EMBRAER exporta aeronaves para o mercado externo. A empresa produziu três gerações de aeronaves (Bandeirante, Brasília e o Jato 145) que, no entanto, foram pouco utilizadas no Brasil (FOUQUET, 2008). Hoje a EMBRAER qualifica-se como uma das principais indústrias do segmento aeronáutico. Segundo Pereira (2004), a empresa possui uma ampla escala de operações que compreende cinco unidades de produção no território brasileiro e algumas subsidiárias internacionais tais como nos Estados Unidos, na França, na Austrália, em Pequim e em Cingapura e ainda possui um projeto de
} 
A EMBRAER, em conjunto com o Instituto Tecnológico da Aeronáutica (ITA), desenvolveu o Projeto Bandeirante (1968), que constituía a idealização de uma aeronave que, pelo seu porte, prestar-se-ia ao atendimento de rotas de baixa densidade de tráfego. No entanto, esse projeto pouco satisfez as necessidades das empresas aéreas brasileiras, que buscavam programar a expansão de rotas mais lucrativas, tais como as nacionais de longa distância e as internacionais. O modelo Bandeirante foi pouco priorizado pelas empresas aéreas nacionais, por ser, principalmente, uma aeronave de capacidade reduzida no transporte de passageiros (FOUQUET, 2008).

Ao tratar a questão da interação do setor de transporte aéreo com a indústria aeronáutica brasileira e a ausência de políticas públicas que incentivem essa coordenação, Oliveira (2009) enfatiza que:

Levando-se em consideração o expressivo potencial de crescimento do transportes aéreo no país, sobretudo no que diz respeito à aviação regional, tem-se que a falta de interação entre os setores de transporte aéreo e de manufatura de aeronaves faz com que o país deixe de explorar efeitos de encadeamentos dinâmicos sobre o crescimento econômico e sobre a competitividade do sistema produtivo, (...), isto porque se trata de setoreschave da economia, capazes de produzir todo um movimento de indução ao longo das cadeias produtivas (...). São setores que, portanto, mereceriam a atenção do planejamento público no fomento, na concessão de linhas de crédito etc. (OLIVEIRA, 2009, p. 38-39).

No entanto, o que se observa historicamente é a não priorização da produção aeronáutica brasileira pelas empresas aéreas de bandeira nacional. Ora pelo que chamam de burocratização da EMBRAER, que dificulta a comercialização entre a empresa produtora e as empresas aéreas, ora pela falta de interesse das empresas brasileiras pelos modelos disponibilizados pela EMBRAER. Ainda assim, a atual condição em que se encontra o setor aéreo brasileiro, com a atuação de empresas consagradas no mercado, vem induzindo uma tendência de retomada das operações aéreas com a inserção da EMBRAER no mercado doméstico, isso é resultado da aquisição de aeronaves por parte de empresas regionais, tais como a Trip Linhas Aéreas, Passaredo Linhas Aéreas e, principalmente, em razão da aquisição de aeronaves pela empresa AZUL Linhas Aéreas Brasileiras.

Os anos de 1970 marcaram novamente a ação estatal no incentivo à aviação comercial regional, com a criação dos Sistemas Integrados de Transporte Aéreo Regional (SITAR). O SITAR era constituído por linhas e serviços aéreos focados no atendimento de localidades de médio e baixo potencial de tráfego. O Brasil foi dividido em cinco áreas 
homogêneas de tráfego, cada uma formando um SITAR. Foram ainda estabelecidas cinco empresas aéreas regionais $^{24}$, cada qual com a designação de atuar em uma das cinco áreas, sob regime de exclusividade.

As áreas originárias de tal divisão não foram estabelecidas apenas segundo critérios geográficos. Outro critério utilizado foi o de capacidade de geração de tráfego total, que deveria ser aproximadamente o mesmo para cada área. Buscou-se, ainda, definir áreas com características geoeconômicas as mais similares possíveis. As linhas aéreas caracterizadas como de baixo potencial de tráfego são aquelas que transportam até 5.000 passageiros/ano, e as linhas de médio potencial de tráfego são as que transportam entre 5.000 e 20.000 passageiros/ano (BNDES IV, 2002, p.2).

Castro e Lamy (1993) argumentam que a criação do SITAR deu plenos poderes para o Ministério da Aeronáutica, que teve a responsabilidade de definir as regiões de implantação e as empresas regionais que operariam as rotas em cada região. A criação do SITAR visava um novo sistema de subsídio às companhias, operando linhas antieconômicas do RIN, a qual supunha desenvolver um sistema nacional e rotas aéreas alimentadoras das principais rotas.

De acordo com as Portarias n ${ }^{\circ} 61$ e 72 de 07 de janeiro de 1976 e 23 de junho de 1977, respectivamente, o SITAR estabeleceu cinco áreas para o serviço aéreo regional no Brasil:

1 - Sistema Norte - Oeste: com a empresa Transportes Aéreos da Bacia Amazônica (TABA), servindo os Estados do Acre e Amazonas, territórios do Amapá, Rondônia e Roraima e parte Oeste do Pará e Norte do Mato Grosso;

2 - Sistema Centro - Norte: com a empresa Viação Brasil Central (inicialmente Votec e posteriormente adquirida pela TAM) operando no então Estado de Tocantins, Goiás e Distrito Federal e parte do Estado do Pará, parte do Maranhão, parte de Minas Gerais e Norte do Mato Grosso;

3 - Sistema Nordeste - Leste: com a empresa Nordeste Linhas Aéreas Regionais, operando na Região Nordeste e parte dos Estados do Piauí, Ceará, Rio Grande do Norte, Paraíba, Pernambuco, Alagoas, Sergipe, Bahia, Maranhão, São Luís, Espírito Santo e Minas Gerais, com ligações que partiam dessas localidades para o Rio de Janeiro, São Paulo, Brasília e Belo Horizonte;

\footnotetext{
${ }^{24}$ De acordo com estudos do BNDES (2002), as empresas estabelecidas para atuar no tráfego regional eram originárias do transporte de táxi-aéreo. Este incentivo ao setor fez com que as empresas de táxi-aéreo desenvolvessem e progredissem na década de 1980-1990 no setor nacional, com foi o caso da TAM (Transportes Aéreos Regionais), que se tornou uma das maiores empresas de transporte aéreo no Brasil.
} 
4 - Sistema Centro-Oeste: com a empresa TAM Transportes Aéreos Regionais (oriunda da Empresa Táxi Aéreo Marília), operando no então Estado de Mato Grosso do Sul, parte dos Estados de Mato Grosso e São Paulo, com ligações destes para o Rio de Janeiro e São Paulo; 5 - Sistema Sul: com a empresa Rio Sul Serviços Aéreos Regionais, operando nos Estados do Sul e Rio de Janeiro e parte do Espírito Santo e São Paulo (litoral).

Correlacionando a fase ascendente do ciclo da economia nacional no início do primeiro quinquênio dos anos de 1980, os resultados do SITAR promoveram a integração regional do transporte aéreo. Aumentou-se o número de cidades servidas pelo modal e, concomitante a isso, diminui-se a concorrência no setor, estimulando assim o desenvolvimento das empresas aéreas em âmbito regional, promovendo a aquisição de aeronaves maiores e mais adequadas para atuar no mercado aéreo comercial. O SITAR tinha como objetivo principal assegurar o transporte aéreo regional no Brasil (FOUQUET, 2008) e, de fato, garantiu seu intuito.

O Governo passou então a incentivar a utilização de aeronaves produzidas no Brasil, e a EMBRAER ganhou destaque na indústria da aeronáutica com a produção dos aviões Bandeirantes. No tocante a isso, o SITAR foi considerado um conjunto de políticas denominado de "Regulação com Política Industrial" (JESUS, 2005). Todavia, não foi suficiente para alavancar a indústria aeronáutica nacional.

O SITAR estabeleceu no cenário da aviação comercial brasileira o esquema de monopólio, ponderado pelo próprio Governo que, mediante a regulamentação do setor por leis e diretrizes, revogava as mediações das estratégias que o SITAR deveria cumprir para o estabelecimento da prestação de serviços aéreos no território brasileiro. De acordo com Garófalo (1982), o SITAR constituía-se como estrutura mercadológica imperfeita de monopólio, já que as bases legais e institucionais que sustentam o mercado de monopólio se direcionam para a criação de barreiras à entrada de eventuais concorrentes. Com isso, o Governo conseguiu evitar que empresas pré-determinadas a operar por região não sofressem o prejuízo da concorrência. Nesse aspecto, o autor defende que em uma estrutura mercadológica concorrencial plena, os serviços aéreos seriam vitalizados e dinamizados, uma vez que o usuário seria mais bem servido em um regime de livre concorrência.

Ainda no mesmo período, em âmbito regional, foram instituídos os Voos Diretos ao Centro (VDC), que eram linhas especiais criadas para ligar, sem escalas, os aeroportos considerados centrais - São Paulo (Congonhas), Rio de Janeiro (Santos Dumont) e Belo Horizonte (Pampulha) - e esses aeroportos com o da Capital Federal (Presidente Juscelino 
Kubitschek), que deveriam ser operados apenas por empresas aéreas de âmbito nacional (ROCHA, 2006).

O desenvolvimento do SITAR, primeiramente, revelou índices estatísticos que representaram uma elevação no número de cidades servidas pelo modal aéreo. Nos principais anos de atuação do SITAR, ou seja, de 1976 a 1980, a quantidade de cidades servidas pelas companhias aéreas regionais passou de 46 para 102, respectivamente (Tabela 2). Nesse momento, o país possuía uma rede de fluxos bem articulada, integrando localidades díspares do território nacional. A expressividade das empresas de transporte aéreo regional (TABA, Votec, Nordeste, TAM e Rio Sul) ultrapassava a quantidade de cidades servidas pelas grandes empresas de transporte aéreo, como a VASP, VARIG, Cruzeiro do Sul e Transbrasil, embora as linhas operadas pelas companhias nacionais apresentassem maior lucratividade por quilômetro voado que as linhas operadas pelas companhias do SITAR.

Tabela 2 - Cidades servidas por companhias aéreas regionais e nacionais (1975 - 1980)

\begin{tabular}{c|c|c}
\hline Anos & Companhias Regionais & Companhias Nacionais \\
\hline 1975 & ------ & $100 \%$ \\
\hline 1976 & $65,7 \%$ & $34,3 \%$ \\
\hline 1977 & $87,6 \%$ & $12,3 \%$ \\
\hline 1978 & $89,8 \%$ & $10,1 \%$ \\
\hline 1979 & $87,9 \%$ & $12,0 \%$ \\
\hline 1980 & $87,9 \%$ & $12,0 \%$ \\
\hline
\end{tabular}

Fonte: Anuário do Transporte Aéreo (vários anos); GARÓFALO (1982)

Org.: Camilo Pereira, 2009

De acordo com Oliveira (2009, p. 85) o SITAR representou "a primeira e última tentativa do Governo estruturar, planejar e fomentar de maneira sistemática e global, o desenvolvimento desse setor, bem como de estabelecer políticas para a aviação regional".

Com a estruturação da política aeronáutica que se estabelecia no Brasil, o setor aéreo defrontou-se, nos anos de 1990, com transformações estruturais econômicas e políticas que atingiram as diversas escalas do tráfego aéreo: internacional, nacional e regional. Assim, se compreende que novos rumos foram traçados para o transporte aéreo brasileiro, modificando toda a estrutura de planejamento de voos, linhas e de cidades que eram servidas pelo modal.

\subsubsection{A nova fase no setor de transporte aéreo: da regulamentação à desregulamentação} (1990 - 2007)

O processo de desenvolvimento da base de orientação do setor aéreo brasileiro tem, atualmente, demonstrado as características verificadas no setor aéreo mundial, que, 
constantemente, foi induzido e influenciado pelas ações do setor aéreo norte-americano. Tais observações são constatadas mediante as definições e diretrizes adotadas pelo Brasil, que iniciou, no final da década de 1980 e início dos anos de 1990, um processo semelhante ao ocorrido no setor de transporte aéreo dos Estados Unidos. A partir da projeção indubitavelmente coerciva do transporte aéreo brasileiro, inseriu-se no país, de fato, um processo de desregulamentação do transporte aéreo.

Esse processo iniciou-se, primeiramente, nos Estados Unidos a partir do ano de 1978, quando o presidente norte-americano Jimmy Carter assinou o Airline Deregulation Act $(A D A)$, promovendo a desregulamentação político-econômica do transporte aéreo doméstico nos Estados Unidos (SIMÕES, 2003). Esse fato iniciou mundialmente um processo de desregulamentação do serviço aéreo. As décadas seguintes compuseram o que se chamou de processo de "desregulamentação ou flexibilização" do setor aéreo. Os resultados, simultaneamente, foram percebidos pelas empresas e pela sociedade.

A partir desse processo de desregulamentação do setor aéreo norte-americano, iniciou-se nos Estados Unidos o surgimento de pequenas empresas que trabalhavam no sistema de tarifas de custos baixos e serviços mais simples como forma de oferecer tarifa mais acessível aos consumidores, processo semelhante ao que ocorreu no Brasil nos anos 2000 (COELHO, 2003).

Posterior à fase inicial da desregulamentação do setor aéreo norte-americano, as consequências ulteriores levaram a falência das pequenas empresas ${ }^{25}$ que haviam surgido nos Estados Unidos. A princípio, o objetivo da desregulamentação no transporte comercial aéreo era aumentar a concorrência na aviação comercial, mas o resultado foi uma rápida concentração em poucos grupos de companhias aéreas que passaram a dominar o mercado nacional e internacional (JESUS, 2005).

As consequências desse processo são discutidas e defendidas por diversos autores, como Tavares (1999), que considera que a desregulamentação do setor aéreo nos Estados Unidos trouxe efeitos positivos para a economia do país, destacando, ainda, que com a desregulamentação, o consumidor norte-americano dispôs de uma maior variedade de combinações preço-qualidade, e as empresas aumentaram seu o nível tecnológico, devido ao fato de estas serem impulsionadas mais ativamente pela concorrência, o que lhes permitiu

\footnotetext{
${ }^{25}$ Nota-se que, igualmente no Brasil, nas décadas de 1940-1950 esse processo foi semelhante, isto é, ocorreu o surgimento de um número considerável de pequenas empresas que não suportando a concorrência entraram em regime falimentar e/ou fusão com empresas maiores, tal fato, mais uma vez, acentua os critérios que utilizamos para a comparação do setor aéreo brasileiro e norte-americano, ou seja, o sistema de normatização dos Estados Unidos afetou e influenciou desde o início a base de operação normatizava do Brasil.
} 
melhorar a qualidade e diminuir custos de produção, aumentando assim a eficiência produtiva.

Castro e Lamy (1993) asseveram sobre a melhoria no oferecimento do transporte aéreo nos Estados Unidos, como a redução das tarifas, maiores opções de preço e qualidade, que concomitantemente foi acompanhada pelo aumento da demanda de passageiros. Asseveram ainda sobre oferecimento de descontos nos bilhetes de viagens de baixa a média distância, que também tem favorecido o desenvolvimento do tráfego aéreo regional. São estratégias que convergem para o desenvolvimento do setor e para a integração regional no país, embora tenha causado grandes crises, com a falência de inúmeras empresas.

O regime de desregulamentação do transporte aéreo no Brasil significou a flexibilização das tarifas, a ausência da fixação de preços das passagens aéreas - que passaram a ser estabelecidos pelas empresas do setor. Regime, este, que, progressivamente, adaptou-se às tendências políticas liberalizantes que o país adotou.

Ao refletirmos sobre as vantagens e desvantagens do processo de desregulamentação setorial e, concomitantemente, do setor aéreo no Brasil, temos posições divergentes sobre tal elucidação. As defesas de que a desregulamentação trouxe grandes contribuições para o desenvolvimento e posterior crescimento do setor de transporte aéreo no Brasil são, de fato, reais. Contudo, estas defesas são admitidas a partir de uma visão macroeconômica sobre o setor aéreo, desconsiderando os resultados advindos para o segmento regional, que se constitui por conexões e fluxos de baixa densidade de tráfego, mas que se caracteriza como um setor de grande importância para a economia do país. Desta forma, as ressalvas a esse processo são inerentes para a compreensão do setor aéreo regional, uma vez que a adoção de medidas de cunho liberal refletiu um efeito de desconexão entre o setor aéreo (segmento regional) e o poder do Estado (entidades reguladoras).

O processo de desregulamentação e normatização do setor aéreo norte-americano influenciou totalmente a estruturação do transporte aéreo brasileiro. Entretanto, diferentemente dos Estados Unidos, as consequências desse processo para o Brasil não têm mostrado benefícios para as empresas e nem para os usuários do transporte aéreo. Considerando as ações e iniciativas do Governo norte-americano, nota-se que, no Brasil, irrefutavelmente, a normatização e as técnicas para os serviços aéreos não correspondem ao interesse do desenvolvimento do transporte, comprovadas pelas crises que passa o setor aéreo atualmente.

Para Castro e Lamy (1993), o Brasil necessita de parâmetros que combinem o crescimento e o desenvolvimento do serviço. Alegam, ainda, que o exemplo da 
desregulamentação norte-americana tem, certamente, lições aproveitáveis para o transporte aéreo no Brasil. Considerando as assertivas de Castro e Lamy (1993), convém retratar que, mais do que um cenário desregulamentado no qual o serviço de transporte aéreo convive, torna-se necessário enfocar mais coerência nas ações do poder legislativo e executivo, na intenção não apenas de deixar o desenvolvimento do setor aéreo à livre iniciativa e à inabilidade de órgãos administrativos. Se resultados internacionais são bons exemplos de crescimento, deve-se, sobretudo, compreender as especificidades e características, ou seja, as múltiplas combinações de cada localidade que estabelecem os parâmetros para o desenvolvimento e crescimento do país.

A segunda metade da década de 1980 caracterizou-se ainda mais pela desregulamentação no setor, resultado das transformações conjunturais que invadiram todos os países, na intenção de configurar a ordem econômica mundial mediante o sistema capitalista. A abertura política nacional conferiu, num primeiro momento, o processo de redemocratização. Todavia, os crescentes problemas de ordem macroeconômica e a necessidade de controle da inflação iniciaram um período em que a política de estabilização passou a ser cada vez mais intrusiva nas questões setoriais, sobretudo nos transportes.

O ajustamento do setor aeroviário, baseado no processo de desregulamentação, constituiu-se em um dos pontos-chave da circulação no território, uma vez que este processo favoreceu a livre iniciativa do setor, o que repercutiu profundas alterações estruturais, que ora foram positivas, ora processaram-se negativamente para a macroeconomia brasileira. Tais mudanças possibilitaram, por um lado, a diversificação e desconcentração das atividades produtivas por todo o espaço nacional e, por outro, a centralização dos setores de gestão ligados à concentração da informação em poucos pontos nodais no espaço (CORDEIRO, 1996). Essa diversificação proporcionou uma volatilidade maior dos deslocamentos de pessoas, informações e mercadorias, possibilitando a contiguidade da capital paulista com seu interior, favorecendo assim as interações espaciais e a conformação de uma rede geográfica para o setor aéreo.

Ainda como forma de consolidar o processo de desregulamentação, em 1986 foi aprovado pela Lei no 7565/1986, em 19 de dezembro de 1986, o Código Brasileiro da Aeronáutica (CBA), que substituiu o Código Brasileiro do Ar. Concomitante à criação do CBA, ocorria o enfraquecimento do Ministério da Aeronáutica e, consequentemente, do DAC e dos militares. Incipientemente, o processo de desregulamentação do setor aéreo fortaleceuse no decorrer dos anos devido à política vigente daquele momento, que era condizente com medidas de cunho neoliberal. Desta forma, a desregulamentação foi inserida na estrutura 
governamental dos anos de 1990 com uma força política capaz de reestruturar a aviação comercial.

O Programa Federal de Desregulamentação instituído pelo Decreto $n^{\circ} 99.179$, de 15 de março de 1990, marcou a nova fase política em voga mundialmente: o neoliberalismo. De acordo com Castro e Lamy (1993, p. 36), o programa iniciava novos tempos para o serviço aéreo brasileiro e fundamentava-se:

No respeito à liberdade individual e objetivando o fortalecimento da iniciativa privada, redução da interferência do Estado na vida e nas atividades do indivíduo, maior eficiência e redução dos custos dos serviços prestados pela Administração Pública Federal e atendimento satisfatório aos usuários desses serviços. As diretrizes básicas do programa eram: a manutenção apenas dos controles e formalidades imprescindíveis, e deixar a atividade econômica reger-se, basicamente, pelas regras do livre mercado.

A política adotada de desregulamentação na aviação comercial resultou em substanciais mudanças para o setor, principalmente com o país sob a presidência de Fernando Collor de Melo, Itamar Franco e, posteriormente, Fernando Henrique Cardoso, que, baseados numa política neoliberal de defesa da desregulamentação setorial, do Estado mínimo, da abertura de capitais ao mercado externo, entre outras, instauraram medidas de caráter neoliberal, como, por exemplo, à medida que extinguiu o funcionamento do SITAR (ESPÍRITO SANTO, 2000). Assim, no ano de 1992, comprovou-se que o setor ficaria à livre decisão e ação das companhias aéreas e à concorrência por elas promovida. Este período conduziu o processo de flexibilização do setor aéreo brasileiro, que, em muito, contribui para a crise atual que assola o setor aéreo.

Espírito Santo (2000) divide esse período em três fases: $1^{\text {a }}$ Fase de Flexibilização, $2^{\mathrm{a}}$ Fase de Flexibilização e $3^{\mathrm{a}}$ Fase de Flexibilização.

$1^{a}$ Fase: marca a facilidade de entrada de novas empresas regulares (o que de fato aconteceu), e o fortalecimento das regionais incumbentes. $\mathrm{O}$ apoio do Estado na permanência de empresas regionais e também políticas que visassem à competição organizada entre empresas nacionais e regionais foram ausentes, o que repercutiu e repercute na constante entrada e saída de empresas no setor aéreo comercial.

$2^{\mathbf{a}}$ Fase: estabelece a livre competição das linhas pool, ou seja, as chamadas "ponte-aérea", por empresas regionais e nacionais. A liberação das linhas pool favoreceu as empresas aéreas regionais. Contudo, a liberação total de linhas - ou seja, tanto as de baixa densidade (regional) como as de alta densidade (nacional) - tem promovido a concorrência agressiva entre empresas de pequeno porte com empresas de grande porte. Essa disputa tem desmotivado o desenvolvimento do segmento regional, uma vez que as empresas de menor porte não 
suportam a concorrência, tendo que se submeterem a acordos comerciais com as grandes empresas como forma de garantir a permanência no mercado.

$3^{\mathbf{a}}$ Fase: caracteriza estruturalmente a alteração da questão empregatícia nas empresas aéreas, a diminuição na obrigatoriedade de funcionários por aeronaves, o que gerou um "enxugamento" nas empresas que, sistematicamente, cortaram o número de funcionários, diminuindo também suas despesas ${ }^{26}$. Nesse âmbito, novas empresas inserem-se no mercado, comprovando a nova fase para a aviação brasileira.

Esse processo de flexibilização do setor aéreo, iniciado na década de 1990, foi desenvolvido sem um planejamento prévio, de controle e ação por parte do Estado, como forma de se incentivar o crescimento do segmento regional. Um plano aeroviário que tenha como meta assegurar a continuidade e a integralização do segmento nacional com o regional é crucial para a integração territorial. Gandra (2007) enfatiza que, no Brasil, não existem diretrizes estratégicas para o desenvolvimento do setor aéreo, o que de fato se observa. Assim, a sistematização de políticas estratégicas que componham planejamento, coerência na concorrência, bem como seguridade para as empresas é essencial para o crescimento do setor. Porém, o que se nota é a diminuição da capacidade estatal na programação de políticas coerentes que promovam o desenvolvimento.

A década de 1990 caracteriza-se pela entrada e saída de empresas no cenário da aviação comercial brasileira, como demonstrado na Tabela 3. Esse processo ocorreu mediante a política desenvolvida no país, que não oferecia respaldo para a permanência das empresas aéreas relegando o mercado às ações da livre iniciativa. As empresas permaneciam no setor mediante uma "seleção natural" coordenada pelo mercado comercial da aviação civil (FOUQUET, 2008).

Tabela 3 - Evolução estatística do setor de transporte aéreo (1927 - 2007)

\begin{tabular}{c|c|c}
\hline Anos & Empresas Aéreas & $\begin{array}{c}\text { Passageiros } \\
\text { Embarcados }\end{array}$ \\
\hline 1927 & 2 & 643 \\
\hline 1937 & 7 & 61.874 \\
\hline 1947 & 12 & 888.752 \\
\hline 1957 & 16 & 3.753 .911 \\
\hline 1967 & 5 & 2.460 .463 \\
\hline 1977 & 4 & $6.000 .000^{* * *}$ \\
\hline 1987 & $*$ & 22.757 .055 \\
\hline 1997 & 16 & 19.421 .029 \\
\hline
\end{tabular}

${ }^{26}$ Tal fato acentuou-se com a aderência das empresas ao meio técnico-científico-informacional que introduziu tecnologicamente equipamentos, máquinas, software etc., capazes de realizar as mesmas funções dos funcionários. Exemplo disso são as vendas de passagens aéreas pelo e-commerce, pelo telefone, entre outros. 


\begin{tabular}{c|c|c}
\hline 2000 & 20 & 33.989 .176 \\
\hline 2001 & 19 & 36.001 .448 \\
\hline 2002 & 18 & 35.923 .807 \\
\hline 2003 & 19 & 33.420 .071 \\
\hline 2004 & 19 & 36.865 .322 \\
\hline 2005 & 23 & 44.504 .115 \\
\hline 2006 & 21 & 47.702 .443 \\
\hline 2007 & 24 & 49.157 .982 \\
\hline
\end{tabular}

* Dados indisponíveis

***Dados estimados

Fonte: Anuário do Transporte Aéreo (vários anos); GARÓFALO (1982)

Org.: Camilo Pereira, 2009

A V CONAC, em 1991, representou a entrada do setor na política de flexibilização que apresentou intensas modificações para o transporte aéreo brasileiro. $\mathrm{O}$ processo de desregulamentação do setor inicialmente passou a incentivar a entrada de mais empresas na aviação comercial, resultando na criação de empresas de táxis-aéreos e de pequenas empresas regionais regulares, tais como a Pantanal Linhas Aéreas, Tajav Linhas Aéreas, Meta Linhas Aéreas, Rico Linhas Aéreas etc. De acordo com Fouquet (2008), a partir do ano de 1992, qualquer empresa de transporte aéreo regular estava autorizada a executar voos nacionais e regionais no território brasileiro. Essa autorização do Governo Federal gerou grandes transformações no mercado aéreo nacional, que passou a definir o conceito de empresa aérea de serviço nacional e empresa aérea de serviço regional. A designação era feita a partir das linhas operadas pelas empresas e não mais como no SITAR, ou seja, por meio de empresas específicas por área de atuação.

As empresas passam então a ser denominadas de "âmbito nacional", isto é, aquelas empresas que compreendiam uma rede preponderantemente de linhas aéreas nacionais, servindo no mínimo 12 Estados da Federação e 8 capitais estaduais. E as empresas de "âmbito regional" correspondiam às empresas cuja rede compreendia preponderantemente linhas aéreas regionais, sem limites no número de Estados ou capitais que seriam servidos (BNDES IV, 2002).

O Governo, ao liberar as bandas tarifárias, estimulou a livre concorrência entre as companhias aéreas nacionais e regionais, dando a possibilidade de empresas que operavam em linhas de baixo fluxo passar a regulamentar suas atividades em âmbito nacional e internacional, como foi o caso da TAM Linhas Aéreas (ESPÍRITO SANTO, 2000). Dentre todas as novas especificações do processo de flexibilização do setor aéreo, as modificações do controle tarifário imprimiam uma nova fase para o setor, o que em partes prejudicou as 
empresas do segmento regional, pois os mesmos passaram a disputar rotas com empresas de grande porte no cenário da aviação comercial brasileira.

Em linhas gerais, a flexibilização do setor contribuiu, num primeiro momento, para o aumento do número de companhias aéreas. Consequentemente houve o crescimento da demanda pelo modal e também da quantidade de cidades servidas pelo setor, melhorando a viabilidade para os usuários que passaram a dispor de mais descontos em virtude da livre concorrência. Mas, em contraponto às vantagens, a desregulamentação acelerou a crise aérea, em virtude da ausência de planejamento e de um Estado forte e regulador.

O transporte aéreo brasileiro passou, desde o início da década de 1990, por importantes modificações em seu ambiente competitivo. Alguns autores consideram que, na medida em que o Governo Federal e, mais especificamente, a autoridade reguladora - o DAC - adotou a Política de Flexibilização do Transporte Aéreo, concedeu maior liberdade, sobretudo na fixação de tarifas e descontos, na entrada e saída das linhas do sistema aéreo e na operação de novas companhias aéreas (BUSTO et al 2006). Porém, há de se considerar que as variáveis desse processo de flexibilização governamental têm exaurido progressivamente o setor de transporte aéreo no segmento regional e as consequências desse processo não têm revelado bons resultados para o setor, principalmente quando se tem como parâmetro o regional.

No ano de 2000, em virtude do cenário em que o setor aéreo encontrava-se, perdendo cada vez mais destaque, foi determinado o fim da distinção entre empresas de caráter nacional e regional, sendo todas classificadas como "Empresas Domésticas de Transporte Aéreo Regular". Os estudos do BNDES destacam e definem claramente o atual cenário da aviação comercial brasileira e a distinção entre as empresas.

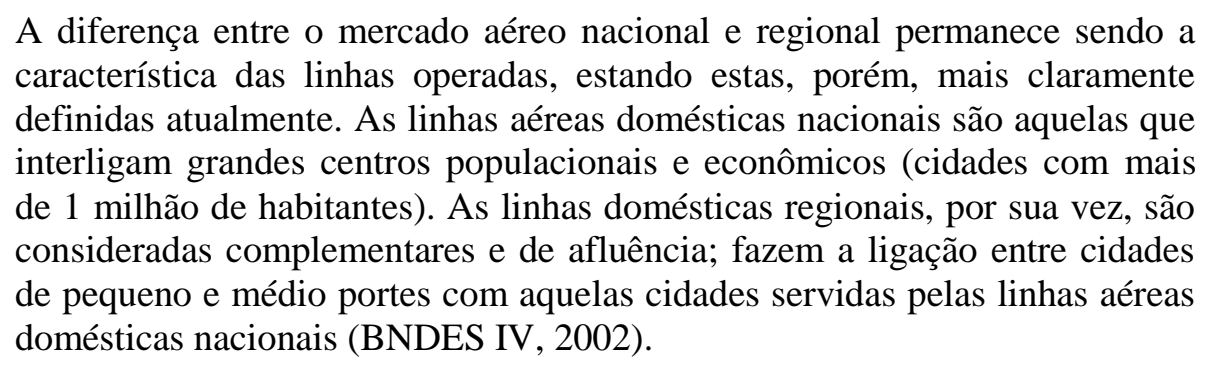

Embora as empresas constituam uma mesma nomenclatura para a prestação de serviço aéreo regular, atualmente percebe-se que a designação das empresas não influi na determinação das linhas, ou seja, as empresas definem as rotas realizadas de acordo com a capacidade aeroviária (número e capacidade das aeronaves) que possuem. Nesse contexto, as linhas nacionais de maior lucratividade são operadas pelas grandes empresas do setor aéreo, 
sendo as rotas de menor distância (com algumas exceções) realizadas por empresas de menor porte e também por empresas nacionais de grande porte.

Nesse momento, vale destacar a entrada no mercado da companhia aérea Gol Linhas Aéreas Inteligentes, no ano de 2001. Baseada em uma nova postura econômica de reestruturação na prestação de serviços aéreos, com estratégias de mercado que personificaram sua força de atuação no setor aéreo, configurando um novo modelo estrutural de competição baseada na estratégia de tarifas reduzidas e custos reduzidos (low cost, low fare $^{27}$, a Gol modificou a atuação das empresas que conseguiram permanecer no mercado após sua entrada.

A remodelagem organizacional e estrutural que a empresa ofereceu ao setor reduziu o crescimento de algumas empresas que tinham um bom desempenho no cenário da aviação e dificultou a retomada do crescimento de outras empresas, provocando em muitos casos a depreciação e o endividamento de empresas como a VARIG e, consequentemente, a falência de outras empresas como a VASP e a Transbrasil ${ }^{28}$. Se, por um lado, a desregulamentação ampliou a dimensão do mercado e intensificou a competição que favorece o usuário, por outro lado gerou a falência, a fusão e a aquisição de empresas que não suportaram a concorrência.

Somam-se a todos esses problemas os acontecimentos no cenário internacional, como, por exemplo, os ataques terroristas que afetaram a economia norte-americana e que repercutiram em todos os mercados aéreos. Os acontecimentos do chamado "11 de setembro" diminuíram a intensidade de voos para os Estados Unidos, principal país de destino do tráfego aéreo brasileiro. A queda da demanda para viagens com destino para o país chegou a provocar uma redução da ordem de 50\% dos assentos ocupados (SIMÕES, 2003).

Ao analisar, novamente, a crise em que se encontra o setor aéreo brasileiro, devese considerar como resquícios o processo de desregulamentação acentuado na década passada, mas que ainda não foram desvinculados do atual Governo de Luis Inácio Lula da Silva, embora no contexto atual o Governo promova o reverso do que ocorreu na década de 1990, ou seja, procura controlar a competição mediante diretrizes que setorizam as empresas aéreas por níveis de voos, isto é, internacional, nacional e regional.

É importante destacar, que ainda que seja incipiente a iniciativa do Governo Brasileiro em alavancar o segmento regional, tal ocorrência tem sido estimulada nos últimos

\footnotetext{
${ }^{27}$ Monteiro (2004) destaca que o modelo low cost, low fare consiste na simplificação do serviço de bordo, padronização da frota e oferta de preços reduzidos.

${ }^{28}$ A VASP entrou em recuperação judicial em 01/07/2005, visando reestruturar seu patrimônio e retomar as operações. A Transbrasil decretou falência no ano de 2001.
} 
anos, sobretudo, com a atual gestão do Ministro da Defesa, Nelson Jobim, que tem promovido projetos e programas com objetivo de estimular a aviação regional no país, principalmente em cidades que não tem acesso ao transporte aéreo. Dentre os programas de incentivo ao segmento, destaca o Programa de Ampliação da Malha Aérea Nacional, que tem como objetivo principal a desoneração tributária, regulação econômica e investimentos em infraestrutura aeroportuária.

No entanto, as iniciativas do Governo junto ao Ministério da Defesa têm, por outro lado, resultado em processos de fusão das companhias aéreas, implicando um novo padrão do sistema aéreo e das companhias, bem como novas estratégias empresariais que remontam em acordos de concentração, fusões e cooperação, contratos de prestações de serviços recíprocos, estratégias concernentes ao conceito low cost, low fare entre outras. Estas alternativas promovem uma integração vertical entre as empresas, o que, em tese, prejudica o usuário que dispõe de um menor número de empresas que oferecem o serviço.

Nesse contexto de análise, a preocupação central é enfatizar que esse período de desregulamentação concerne a uma política implementada, que não tem contribuído para a retomada do crescimento do setor aéreo. A necessidade de estímulo à aviação comercial regional e extra-regional é fator de competência do Estado. Gerir políticas que dêem condições para as empresas operarem voos com garantia de demanda e oferecer infraestrutura aeroportuária e empresas regulares é função do Governo. Uma política entre setor público (Governo) e o setor privado (empresas) pode garantir o desenvolvimento e o crescimento do setor aéreo regional, sobretudo no Estado de São Paulo, que oferece uma rede aeroviária bem estruturada para a aviação regional.

Compreende-se, assim, que a política de flexibilização da aviação comercial brasileira, levada adiante pelas autoridades reguladoras no início da década de 1990, intensificou sistematicamente uma concorrência ruinosa ${ }^{29}$ no setor aéreo brasileiro, o que pode ser verificado como maior ênfase no segmento aéreo regional do Estado de São Paulo.

A defesa aqui apresentada não corresponde à eliminação da concorrência entre as empresas, pois se entende que a concorrência pode, até certo ponto, favorecer o usuário, as cidades servidas, o desenvolvimento econômico dos centros urbanos onde se localizam os aeroportos, etc. Contudo, a concorrência deve e pode ser combinada numa relação entre políticas do Governo que promovam a competição, determinando os limites por segmento, de forma que a competição entre as empresas de grande porte e empresas de pequeno e médio

\footnotetext{
${ }^{29}$ Ver Capítulo IV.
} 
porte não se torne predatória, como visto no Estado de São Paulo. Nesse sentido, propõe-se, como já elucidado, uma política de "combinação" entre o Governo (que determinaria as condições de concorrência) e as empresas (que reorganizariam o setor em promoção ao desenvolvimento do transporte aéreo nos diversos segmentos, principalmente o regional).

Numa análise mais prática, destaca-se que, no que tange ao setor de transporte aéreo em âmbito nacional e, consequentemente, em âmbito regional no Estado de São Paulo, observa-se duas grandes empresas que duopolizam o setor, isto é, a TAM Linhas Aéreas e a Gol Linhas Aéreas Inteligentes. Nesse sentido, verifica-se a atuação maciça dessas empresas na operacionalização de voos com origem/destino no Estado de São Paulo. Mesmo diante da presença de empresas regionais de pequeno e médio porte, tais como Pantanal Linhas Aéreas e Passaredo Linhas Aéreas realizando voos no Estado, a TAM e a Gol movimentam um processo de fusão que tem confirmado a crescente atuação dessas empresas no setor aéreo, como demonstrado no Gráfico 1, que apresenta a evolução do número de passageiros transportados pelas empresas.

Nota-se, que após a entrada da TAM (1997) e, principalmente da Gol (2001) a atuação de outras empresas aéreas, sistematicamente, diminuiu. A redução no número de passageiros transportados pelas outras empresas no período entre 1995 e 2007 foi de $82 \%$. Já as empresas TAM e Gol tiveram um aumento de $42 \%$ e $39 \%$, respectivamente.

Gráfico 1 - Evolução do número de passageiros transportados pelas empresas TAM, Gol e Outras empresas* (1997 - 2007)

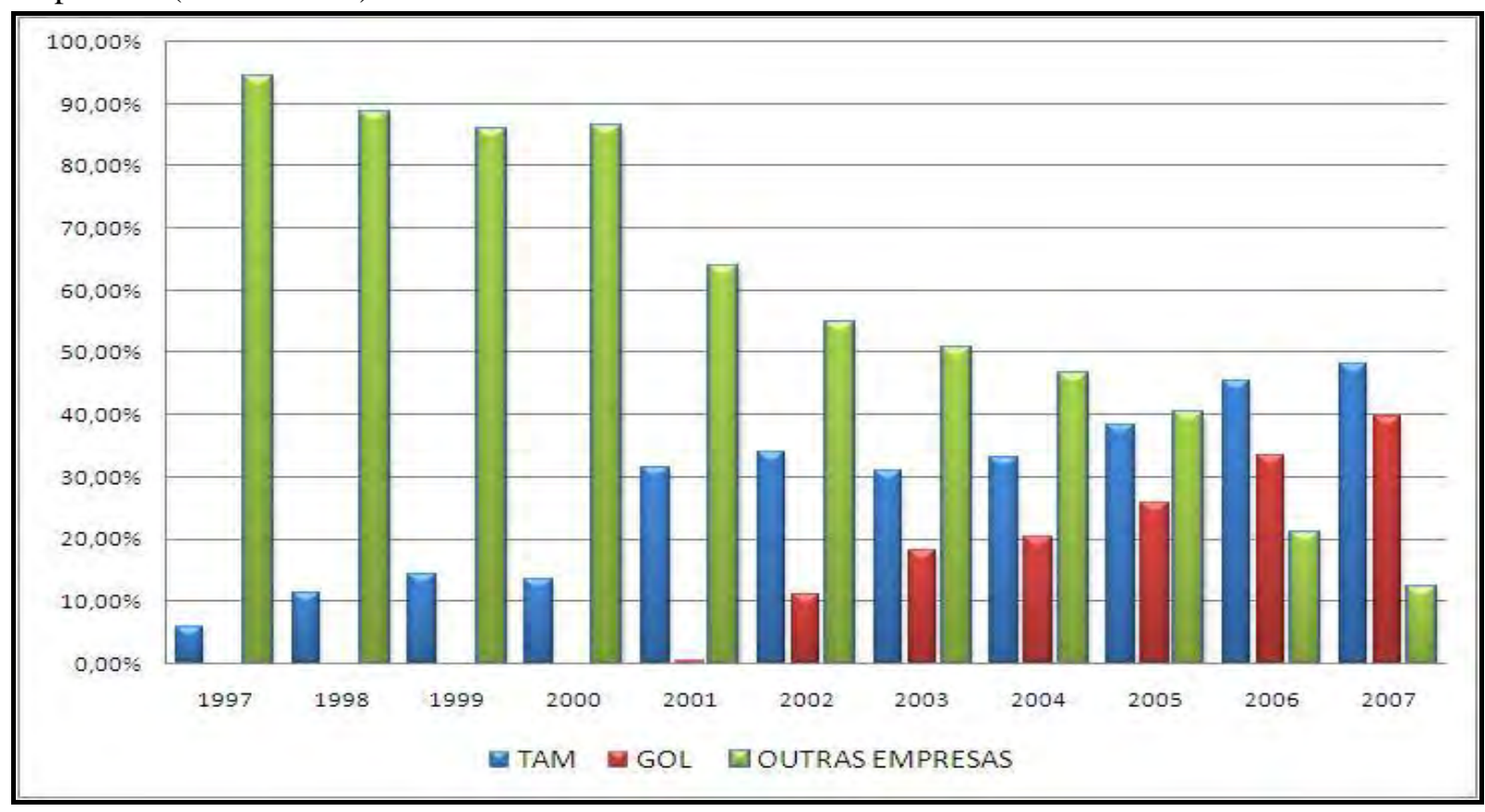

* Outras empresas: número variável de 16 a 22 companhias aéreas

Fonte: Anuários do Transporte Aéreo, (vários anos)

Org.: Camilo Pereira, 2009 
Em 2003, com o novo Governo Federal e, seguindo algumas novas orientações (ainda que incipientemente) de política setorial, o regulador DAC voltou a programar alguns procedimentos de interferência econômica no mercado, objetivando controlar o que foi chamado de "excesso de capacidade das empresas", ou seja, a autonomia da ação das empresas e o acirramento da "competição ruinosa" no mercado (OLIVEIRA, 2007).

Em 2005, mediante a Lei ${ }^{\circ} 11.182$ cria-se a ANAC, vinculada ao Ministério da Defesa substituindo o DAC ${ }^{30}$. A agência tem a incumbência de atuar como autoridade da aviação civil, determinando a adoção de medidas necessárias para o atendimento do interesse público e para o desenvolvimento e fomento da aviação civil, da infraestrutura aeronáutica e aeroportuária do país.

Todavia, com essa iniciativa, a partir do ano de 2005 verificou-se um processo de fusão de pequenas e médias empresas junto às empresas TAM e Gol, que têm proporcionado a centralização do setor aéreo. Desta forma, nota-se, atualmente, o transporte aéreo delegado a essas duas empresas, que coordenam e determinam o transporte aéreo brasileiro ao âmbito de um duopólio, que tem caracterizado suas diretrizes e perspectivas.

Embora a nomenclatura residente no setor aéreo não tenha mais diferenciação de âmbito nacional e regional, defendemos que o transporte aéreo com características regionais, ao atender localidades interioranas, promove uma maior integração territorial e, nesse sentido, consubstancia a dinâmica da interação espacial e, portanto, demanda respaldo, como um setor de promoção ao desenvolvimento econômico regional.

Em síntese, na análise sobre as empresas aéreas do segmento regional, nota-se que, nos últimos anos, várias empresas entraram e saíram do setor de transporte aéreo regional, o que demonstra a ausência de uma política de integralização das empresas e do Governo no intuito de planejar a aviação comercial regional. Compreendemos, portanto, que esse processo de abertura econômica nacional, regida por um movimento político econômico ideológico, tem provocado a substancial diminuição da importância do transporte aéreo regional, seja no que se refere ao número de cidades servidas, seja no número de empresas que oferecem o serviço às cidades localizadas no interior dos Estados.

\footnotetext{
${ }^{30}$ Para Oliveira (2009, p. 99) a criação da ANAC significou "a troca oficial do regulador do transporte aéreo, que passou a ser constituído por uma agência fora do âmbito da administração pública direta e de cunho não-militar." Isso impulsionou a diminuição do poder militar no setor aéreo, embora ainda se observe uma grande atuação desse segmento da sociedade no setor de transporte aéreo, sobretudo do ramo da aeronáutica, vinculado ao Ministério da Defesa.
} 
No desenvolvimento do contexto histórico-evolutivo da aviação comercial no Brasil, é possível observar que as empresas aéreas, apesar de privadas, funcionam como empresas símbolos do país, ou seja, enquadraram e enquadram um mercado que praticamente é exclusivo para as empresas brasileiras. As linhas regionais e nacionais constituem assim "reserva de valor" no país. Essa situação faz parte da regulamentação nacional, que preserva o mercado como reserva para as empresas brasileiras. Resta assim eficácia no planejamento do transporte aéreo, que necessita vislumbrar o crescimento do setor mediante a coerência entre as empresas e o Governo.

Nessa revisão histórica sobre o desenvolvimento do transporte aéreo brasileiro, nota-se que o setor, irreversivelmente, confrontou-se com momentos de pleno crescimento e outros de estagnação, oriundos e resultantes dos ciclos econômicos externos e internos, mas que, simultaneamente, foram convergindo para o crescimento de algumas companhias e a falência de outras. Em síntese, o processo de estruturação da aviação comercial no país consolidou o desenvolvimento do transporte aéreo, que apesar das constantes crises observáveis atualmente, reflete um setor de grande importância econômica para o Brasil.

\subsection{Considerações finais ao capítulo I}

A abordagem do primeiro capítulo revela o desenvolvimento do transporte aéreo mundial de acordo com o capitalismo vigente. No tocante a isso, observa-se que mediante as formas de produção e consumo atuais, novos padrões de mobilidade territorial são impostos e esses exigem cada vez mais a velocidade dos sistemas de movimento.

A mundialização do capital, elucidada por Chesnais (1996), ou globalização econômica, enfocada por Gonçalves (2003), são versadas nesse capítulo tendo como base o meio técnico-científico-informacional sistematizado por Santos (2002) e correlacionado às revoluções e evoluções logísticas definidas por Silveira (2009). Essa correlação permitiu compreender as invenções e inovações tecnológicas que possibilitam o desenvolvimento econômico territorial no contexto das interações espaciais.

A lógica do capital definiu, no decorrer do tempo, países que se manifestaram hegemonicamente nas relações de produção e consumo e, com isso, projetaram mundialmente suas ações, seja em caráter econômico, social, cultural etc. Como base de elucidação prática no âmbito do transporte aéreo mundial, tomou-se como influência o desenvolvimento do setor de transporte aéreo norte-americano, que possui um padrão de transporte aéreo dinâmico e que se desdobrou mediante ações e propostas para o setor de transporte aéreo que repercutiram mundialmente, influenciando, normativamente, países como o Brasil. 
Nessa perspectiva, traçou-se uma contextualização histórico-evolutiva do transporte aéreo comercial no Brasil, no qual se evocou a intenção desse trabalho, que se baseia na identificação e compreensão do transporte aéreo regional de passageiros. A partir desse enfoque, analisa-se o transporte aéreo no Brasil desde sua origem estritamente comercial, isto é, desde o início dos anos de 1910 até o ano de 2007, evidenciando suas fases de auge coincidentes com as fases ascendentes dos ciclos econômicos e suas crises, também análogas as fases depressivas dos ciclos econômicos. Assim, configura-se um quadro evolutivo do desenvolvimento do transporte aéreo no Brasil, que, de forma específica, contribuiu e contribui para a integração territorial, para a intensificação das interações espaciais, bem como para o desenvolvimento econômico nacional.

No tratamento histórico-evolutivo do setor comercial de transporte aéreo brasileiro de passageiros, ressalta-se como um momento importante e definidor das mazelas atuais o período a partir do final da década de 1980, fase correspondente ao processo de "desregulamentação do setor aéreo".

Esta fase definiu a atual situação de crise em que se encontra o transporte aéreo. Nesse sentido, observa-se que resultado do contexto político-econômico mundial e, sobretudo brasileiro, as escolhas políticas e ideológicas que o país optou contribuíram para o agravamento da crise aérea. Compreendemos que a atuação do Estado é inerente nesse processo de recuperação do setor comercial aéreo. Enfatiza-se, para tanto, um Estado forte e regulador em que se preze a ação conjunta do Governo e das empresas aéreas, no intuito de promover o desenvolvimento e crescimento do transporte aéreo.

Considera-se, assim, que esta abordagem, mais do que um aporte histórico sobre o transporte aéreo comercial, possibilitou compreender e ilustrar o desenvolvimento do setor baseado no contexto da lógica da mundialização do capital e no modo de produção capitalista, versado, principalmente, nos ditames do mundo contemporâneo, isto é, das relações de produção e consumo da sociedade que busca e promove a supressão do espaço pelo tempo (HARVEY, 1992).

Nesse contexto de análise, o próximo capítulo apresenta o transporte aéreo regional no Estado de São Paulo, especificando, desta forma, o recorte espacial e temporal analisado na pesquisa, enfocando o desenvolvimento do segmento aéreo e a ação estatal no desenvolvimento da aviação comercial regional. 


\section{CAPÍTULO II}

TRANSPORTE AÉREO REGIONAL NO ESTADO DE SÃO PAULO: O PAPEL DO ESTADO NA GESTÃO DO TRANSPORTE AÉREO 
Nas últimas décadas, temos assistido profundas mudanças na composição técnica dos territórios que, sistematicamente, impõe novas formas de circulação territorial. Acompanhamos novas e intensas remodelagens dos sistemas de circulação, que têm se projetado a partir do que Santos (2002) chama de "frenesi da velocidade". Os meios de transportes necessitam de intensos reajustes, modernizações e inovações que os tornem mais acessíveis, articulados e dinâmicos (flexíveis), do ponto de vista da velocidade do tempo no espaço para que a circulação materialize-se.

$\mathrm{Na}$ identificação dos conceitos que corroboram as explicações mais comumente encontradas para a definição da circulação, baseamo-nos na sintética explicação de Pini (1995, p. 140), para quem a circulação é “a manifestação tangível sob a forma de fluxos de mercadorias, pessoas, capitais, ideias, informações e relações entre as ligações"31.

Diante da conceituação da circulação, referida por Pini (1995), consideramos que a nova composição técnica dos territórios requer a articulação entre os territórios como forma de intensificar as interações espaciais, bem como a circulação. A materialidade espacial cada vez mais compreende a dinamicidade dos meios de transportes a partir das inovações tecnológicas e mediante a processualidade temporal que engendra as relações entre os territórios e entre os agentes sintagmáticos:

Durante um longo tempo, mais precisamente até o advento do telégrafo, vigorou uma percepção de espaço vinculada às limitadas possibilidades de deslocamento de pessoas, mercadorias e informações, imprimindo contornos acentuadamente locais ao uso do espaço pela ação humana. A experiência de transitar por um espaço formado a partir de pontos bem conectados entre si, ampliada atualmente pela difusão das recentes inovações tecnológicas, permite que se estabeleçam relações econômicas numa base espacial caracterizada, em grande parte, pela descontinuidade física (RAMOS, 1998, p. 77).

Santos (2003), ao discorrer sobre a difusão de inovações tecnológicas em países subdesenvolvidos, alude sobre a existência de um acordo geral acerca da necessidade de se introduzir a noção de tempo na Geografia; por isso a importância dos estudos sobre a difusão espacial de inovações em relação ao tempo. Compreende-se que a temporalidade consubstancia mudanças profundas nas normas, nas formas, nas técnicas, nas ações e nos objetos que são aperfeiçoados no decorrer do tempo.

Nessa perspectiva, a interpretação de Silveira (2009) sobre as revoluções e evoluções logísticas contribui para a compreensão das inovações tecnológicas como

\footnotetext{
31 "Manifestation tangible sous forme de flux de marchandises, persones, capitaux, idées, informations et relations entre les lieux" (PINI, 1995, p. 140).
} 
incremento a todo processo de desenvolvimento econômico, sobretudo por tratá-las em sua peculiaridade temporal.

Sua análise permite compreender a configuração e o desenvolvimento dos meios de transportes no Brasil. Nesse sentido, o autor refere-se à intensidade das invenções e inovações nos meios e vias de transportes e, por conseguinte, nas interações espaciais como processos descontínuos que nem sempre obedecem a uma lógica ascendente. Elas apresentam períodos de expansão e retração tecnológicas e de continuidades e descontinuidades históricoespaciais regidas pelas fases ascendentes e depressivas dos ciclos econômicos de longa duração (SILVEIRA, 2009).

O desenvolvimento do capitalismo faz-se através de uma sequência de revoluções industriais ou, como agora dizemos, de revoluções técnicas e científicas (RANGEL, 1983). Nessa perspectiva, Silveira (2009) realiza uma sistematização das consequências e desdobramentos das revoluções e evoluções logísticas sobre o Brasil, alegando que:

Os impactos das revoluções logísticas sobre o Brasil foram amplos, apesar do país não participar, em nenhum momento, da liderança tecnológica e comercial global. Todavia, as elites políticas e econômicas, para atender suas necessidades, procuraram implantar os mais novos sistemas de comunicação. Partiu-se da implementação dos transportes marítimos, ferroviário, hidroviário, rodoviário-automobilístico, aeroviário até se chegar aos modernos meios de telecomunicações. Esses sistemas de circulação proporcionaram ao país uma fluidez capaz de integrá-lo [...] (SILVEIRA, 2009, p.15).

A partir das especificações referidas às evoluções e revoluções logísticas que se baseiam na temporalidade espacial dos fatos, permitimo-nos considerar que as inovações tecnológicas configuram, numa lógica capitalista, o espaço de produção e também de consumo, isto é, as inovações, ao projetarem dinamismo ao processo produtivo, favorecem a fluidez territorial que, nesse sentido, motiva as interações econômicas, sociais e espaciais, contribuindo para a integração territorial e, também, para o consumo nos territórios.

O consumo, por assim dizer, das formas estabelecidas no espaço (sistemas de objetos) são particularidades que a sociedade produz e consome. Em outras palavras, significa dizer que os meios de transportes, que são os sistemas de objetos, confirmam-se como formas que são consumidas pela sociedade. É nesse contexto que o transporte é produzido e consumido, simultaneamente, ao momento do seu uso (HARVEY, 2006).

Ao tratarmos as inovações tecnológicas como fatores essenciais para o desenvolvimento econômico e territorial, não nos baseamos no determinismo tecnológico como análise exclusiva da pesquisa, mas buscamos evidenciar o papel inerente que rege todo 
processo evolutivo dos meios de transportes, sobretudo do transporte aéreo. Compreende-se, a partir dessa contextualização, que as invenções e inovações tecnológicas estão associadas aos meios de transportes e, concomitantemente, correspondem à intensificação das interações espaciais.

Quando se trata das inovações tecnológicas, bem como das invenções ligadas à otimização do processo produtivo e à sistematização do modo de vida vigente, que se baseia numa economia de mercado e consumo, tem-se que os meios de transportes são, de fato, um "bem material" a ser consumido, seja ele na esfera da circulação de mercadorias, seja na esfera da circulação de pessoas. Nesse sentido, vê-se que o transporte aéreo faz parte de um "circuito espacial da circulação", no qual tem a mobilidade territorial como atributo para o incremento das interações espaciais e para a dinâmica do desenvolvimento regional.

A aderência conceitual ao termo "circuito espacial da circulação" obedece à lógica referencial teórico-metodológica sobre os circuitos espaciais de produção evidenciados por Santos (2003), em sua obra Economia Espacial. Todavia, considera-se o circuito espacial da circulação como um conceito referenciado a partir da mobilidade, isto é, dos deslocamentos físicos (de pessoas e mercadorias). Buscamos, desse modo, correlacionar circulação, mobilidade material e imaterial, fluxos e fixos etc., num complexo sistema que envolve as inovações tecnológicas, a supressão espaço-tempo, a integração territorial e suas implicações econômicas e espaciais.

Ao tratar os circuitos espaciais da circulação na óptica dos transportes modernos e da Geografia Econômica e dos Transportes, considera-se que esse processo é revelado a partir da estrutura técnica, sistêmica ou, em outras palavras, infraestrutural, no qual o transporte aéreo está inserido, ou seja, aquele dos sistemas de objetos e de ações (SANTOS, 2004) que respondem pelas combinações dos elementos definindo os espaços de interesse do capital, no qual o transporte aéreo pode exercer influência e articular territórios espacialmente descontínuos.

Nesse contexto, Arroyo (2006) adverte que, ao discorrer sobre os circuitos espaciais de produção, tem como instrumento analítico os fluxos materiais e não-materiais, ou seja, de pessoas, de mercadorias, de capital e de informação. A autora define, ainda, que esses fluxos regulam o processo produtivo e asseguram a materialização do capital, uma vez que são eles que criam as condições para a circulação e para o processamento das interações espaciais. Diante da configuração socioespacial que os fluxos desenham nos territórios, Arroyo (2006) sistematiza enfatizando a importância da circulação a partir do processo de formação e integração dos territórios. 
Desse modo, o transporte aéreo reflete sua importância econômica para o país, na medida em que favorece a integração territorial, conferindo também a mobilidade geográfica do capital. No tocante a isso, admite-se que a funcionalidade do modal aéreo permite uma acessibilidade que favorece a fluidez territorial a partir das densidades dos fluxos que comprimem cada vez mais o espaço em relação ao tempo.

Baseados na temporalidade espacial que possibilitou o desenvolvimento dos meios de transportes e do modal aéreo, observa-se que o Estado de São Paulo engendra uma importante articulação para a promoção da dinâmica do circuito espacial da circulação. Assim, esboçaremos a contextualização do setor de transportes aéreo no Estado de São Paulo, bem como a valorização de novos espaços paulistas, como essencial para a articulação aérea no Estado e também para a dinâmica territorial urbana e regional.

\subsection{O setor de transporte aéreo no contexto de valorização de novos espaços paulistas}

A circulação aérea torna-se especialmente importante entre os sistemas de fluxos, pois permite realizar a complementaridade entre porções especializadas do espaço, ligando-as a outros territórios. A esta ligação inclui-se a demanda pelo transporte aéreo, que tem fomentado o desenvolvimento regional e tornado ainda mais interessantes determinados territórios no sentido de atrair novos negócios (CORDEIRO; LADEIRA, 1993).

A eletrônica digital, a informática e o desenvolvimento da propulsão a jato das aeronaves e os sistemas de navegação transformaram o transporte aéreo numa modalidade segura, eficiente e econômica de deslocamentos de passageiros, dos fluxos de correio e, também, de diversas mercadorias. Desde suas raízes históricas ou de seu período de maturação, a aviação civil adquiriu credibilidade e aceitação pela sociedade, o que contribui para a articulação e integração territorial do país (SILVA, 1991).

Corrêa et al (1977), em suas análises sobre o sistema de transporte aéreo e sua importância no contexto de desenvolvimento e crescimento das cidades, compara o transporte aéreo com outros modais destacando sua influência na estrutura espacial dos sistemas urbanos e na otimização de seu uso, que para o autor já é bastante marcante, pois seu crescimento e desenvolvimento, em decorrência do rápido avanço da tecnologia, têm sido, muitas vezes, mais acelerado do que qualquer outro tipo de transporte.

De acordo com Gandra (2007), o setor de transporte aéreo é influenciado por múltiplos fatores, como, por exemplo:

- Os tecnológicos, como nível e qualidade da frota das empresas;

- Os sistêmicos, entre eles as malhas de rotas, a demanda por origem/destino; 
- Os comerciais, configurados nas estratégias de vendas, marketing da empresa, informatização, etc.;

- Os institucionais, fundamentados em legislações, acordos internacionais, atos legais específicos e, principalmente;

- Os fatores econômicos.

Dentre os fatores preconizados por Gandra (2007), iniciamos enfatizando a questão da tecnologia que sistematiza o setor de transporte aéreo quanto à velocidade dos deslocamentos.

O processo de supressão do espaço em relação ao tempo, que alcançou uma escala mundial no terceiro quartel do século passado, intensificou-se no decorrer desse século, levando-nos a uma realidade espacial eficiente e fortemente articulada, evidenciando, ainda mais, a importância das redes. Este cenário adquiriu uma notável complexidade, possibilitada pelos avanços técnicos nos sistemas de transportes e de comunicação (RAMOS, 1998).

O modal aéreo possibilita velocidade nas ações, brevidade do tempo de deslocamento, facilidade de acesso a regiões inóspitas e interconexão entre os pontos principais do território brasileiro. Segundo Vieira (2003), a principal vantagem do transporte aéreo é sua maior rapidez, o que facilita a utilização de estratégias just in time. Para Paterson (1975), o moderno transporte aéreo possui duas óbvias e notáveis vantagens: a velocidade empreendida pelo modal e a ausência das dificuldades de que sofrem outros modais devido aos obstáculos físicos. Nessa mesma análise, Derruau (1982) destaca:

A mais recente descoberta da técnica moderna, o avião, é comparável ao barco no sentido em que o ar é cruzável em todos os sentidos, mais ainda do que o mar (...). Mas se o transporte por água é lento sendo, no entanto econômico para as grandes massas, o avião é rápido e hostil ao peso (DERRUAU, 1982, p.166).

Cordeiro e Lacerda (1993) alegam que entre os circuitos espaciais da produção e da circulação, movem-se, além da matéria e da informação, os homens, que traçam o destino dos espaços. Nesse âmbito, para que a circulação seja processada, os diferentes pontos dos territórios necessitam de uma articulação precisa entre eles; articulação, esta, que não se restringe apenas às grandes distâncias territoriais, mas também aos pontos de pequena distância, como, por exemplo, entre as cidades localizadas no interior do Estado de São Paulo.

É nesse contexto que o transporte aéreo tem-se configurado como um modal intrínseco na conectividade entre os diversos pontos do território. Corrêa et al (1977), ao centralizar a discussão da estrutura do sistema urbano por meio dos fluxos aéreos de passageiros, diz que é através das ligações aéreas que boa parte das interações se realizam, 
como, por exemplo, as atividades desenvolvidas em torno da centralização da administração de empresas e instituições e do setor de produção destas, que projetam um alcance espacial que interessa diferentes regiões.

O processo de desconcentração industrial (NEGRI, 1988; LENCIONI, 1994; POCHMANN, 2004) no Estado de São Paulo torna cada vez mais importante à integração regional entre a capital paulista e seu interior e entre as cidades localizadas no interior, incluindo o litoral paulista, uma vez que a interiorização das indústrias impõe a mobilidade dos agentes sociais e econômicos envolvidos com as mais diversas atividades econômicas. As relações econômicas estabelecidas em virtude da desconcentração das indústrias de São Paulo rumo ao interior têm manifestado importantes papéis para as cidades do interior, não mais secundárias, mas como centros polarizadores que empreendem novos arranjos produtivos e de consumo e que contribuem sobremaneira para o desenvolvimento territorial.

Segundo Negri (1988), a preocupação com o caos urbano na Região Metropolitana, decorrente da concentração industrial, iniciou, nos anos de 1960, uma transformação na estrutura locacional das indústrias no Estado. Na década de 1970, a Região Metropolitana de São Paula detinha 74,7\% de atividades industriais. Hoje, esse percentual equivale a 58\% (SILVEIRA, 2009a).

O esforço de reordenamento da estrutura industrial do país estabeleceu as prioridades e diretrizes para o processo de desconcentração produtiva da cidade de São Paulo. Para Codato (1997), esse período constituiu a prioridade à construção da infraestrutura de energia elétrica, transportes, comunicação, saneamento e habitação fora da região concentrada de São Paulo.

Para Pochmann (2004), o processo de desconcentração das indústrias e a reestruturação e localização produtiva no Estado de São Paulo, seguiram o modelo vislumbrado no início dos anos de 1980, que introduziu o surgimento de novos arranjos produtivos possibilitando com isso o fortalecimento de novos espaços produtivos que engendram desenvolvimento regional.

A reestruturação produtiva, além de estar associada ao surgimento de novos arranjos produtivos - mais propícios a surgirem fora dos grandes centros industriais tradicionais - viria acompanhada de deslocamento de áreas inovadoras, pelo surgimento ou consolidação de novos centros produtivos, com novas formas de articulação (...). As regiões industriais tradicionais perderiam competitividade e não estariam no rol de regiões que ganham (POCHMANN, 2004, p. 114).

Tal processo desencadeou novas dinâmicas territoriais no Estado de São Paulo. As indústrias favoreceram a conformação dos eixos de circulação, que passaram a demandar dos 
transportes uma maior intensificação de sua reprodução, ou seja, na medida em que a desconcentração industrial ampliava-se para o interior do Estado, os transportes configuraram a materialização do processo econômico estadual, uma vez que eram responsáveis pela circulação de pessoas, mercadorias, documentos, informações, etc.

O sistema aeroviário é, portanto, um dos pontos-chave da circulação territorial desse período e, hoje, tem um papel ainda mais relevante na interconexão da metrópole com o interior. Sua estruturação, no que diz respeito a sua funcionalidade, à brevidade do espaço no tempo, ao seu conjunto técnico de fixos e a sua articulação com o sistema urbano, - fatores, estes, que favorecem a demanda pelo modal, - têm possibilitado às pessoas os deslocamentos rápidos e convenientemente dispersos pelo território nacional.

Nessa perspectiva, o setor de transporte aéreo foi favorecido nas últimas décadas, mais precisamente após 1970, pelas profundas alterações econômico-territoriais ocorridas no Estado de São Paulo. A desconcentração das atividades produtivas e a centralização dos setores de gestão e controle dessas atividades, que estão situadas nos grandes centros econômicos do país, sobretudo na metrópole de São Paulo, intensificaram a demanda pelo transporte aéreo no interior do Estado em articulação com a capital. Com isso, o setor pôde expandir sua atuação pelo interior, fomentando as interações espaciais entre os territórios e, por conseguinte, promovendo o desenvolvimento econômico regional em novos espaços paulistas.

Para Correia et al (1977), os meios de transportes exercem importante papel para o desenvolvimento das cidades, visto que há um estreito relacionamento entre os meios de transporte e a urbanização. Ao longo de toda a história da humanidade, as vias de transporte têm contribuído para a estruturação dos sistemas urbanos, para a formação das áreas de influência dos centros urbanos e para a definição dos pontos nodais de tais sistemas. Alegamos, ainda, que o sistema aeroviário tem permitido e fomentado dinâmicas territoriais capazes de atrair investimentos e desenvolvimento local nas cidades onde opera o transporte aéreo.

Para tanto, algumas cidades despontaram como grandes espaços de investimentos e dinamizaram-se atraindo novos negócios para suas regiões, imprimindo a valorização espacial no interior do Estado. Entre essas novas territorialidades apontadas para o crescimento do transporte aéreo no Estado de São Paulo, destacam-se centros urbanos que têm sido impulsionados pelo crescimento econômico mediante diversas atividades econômicas, que estão relacionadas à indústria, mas também a setores tais como a agropecuária, comércio e serviços. 
É a partir desse processo de desconcentração urbano-industrial, que promoveu a expansão das novas territorialidades no Estado de São Paulo, que se verifica o importante papel desempenhado pelo setor de transporte aéreo, na conectividade e integração entre os nós das redes do espaço geográfico que, neste trabalho, são compreendidos enquanto elos entre os setores de produtividade e consumo. Assim, as cidades estão inseridas em uma rede de relações sociais e econômicas, independentes, mas análogas e, cumprem a função de cidades polarizadores de seus respectivos entornos. Desse modo, temos como referência empírica as cidades que são autorizadas para a operacionalização de voos regulares no transporte de passageiros. Nesse sentido, as cidades analisadas neste trabalho são: Araçatuba, Bauru, Marília, Presidente Prudente, Ribeirão Preto e São José do Rio Preto (Mapa 1). 


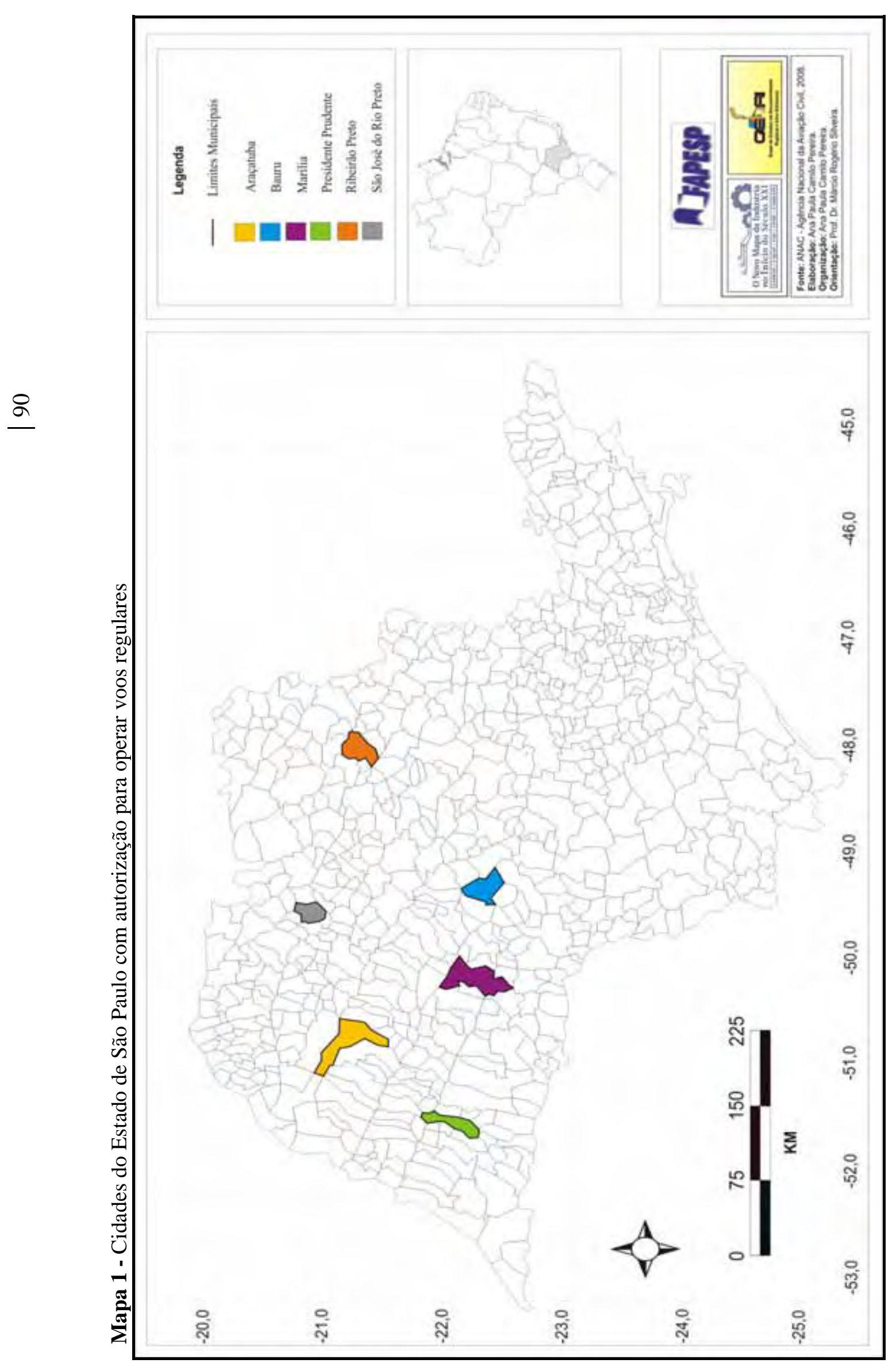


Cabe, portanto, neste contexto de análise, permear breves considerações sobre a gênese e o desenvolvimento do setor aeroviário no Estado de São Paulo, promovendo, desse modo, a interpretação histórico-evolutiva dos desdobramentos da aviação comercial na cidade de São Paulo e, sobretudo, nas cidades do interior do Estado que operam voos regulares.

\subsection{Gênese e desenvolvimento do transporte aéreo no Estado de São Paulo: a demanda e a oferta de fluxos}

O desenvolvimento e a formação territorial são condicionantes essenciais para compreender a evolução do setor aéreo no Estado de São Paulo. Assim, o referencial teórico utilizado consubstancia-se nas múltiplas determinações em que se deu o crescimento das cidades supracitadas, bem como da cidade de São Paulo.

O transporte aéreo regional desenvolveu-se mediante o processo de industrialização em São Paulo e, posteriormente, seguiu o desencadeamento das indústrias rumo ao interior do Estado, reorientando toda a dinâmica produtiva e de consumo.

Tal esclarecimento vem ao encontro da configuração socioespacial paulista, que permite elaborar uma cronologia do processo industrial como uma forma de verificar a contextualização do desenvolvimento aéreo no Estado. Desta forma, o entendimento da industrialização no Estado de São Paulo insere-se para demonstrar sua intrínseca relação, ou seja, o crescimento industrial demandou e ainda demanda a materialização da circulação, que é objetivada pelos meios de transportes, como o aéreo. Embora não seja o objetivo principal do trabalho, a constante chamada do processo de industrialização é essencial para a compreensão do desenvolvimento do setor de transporte aéreo.

O setor de transporte aéreo no Estado de São Paulo desenvolveu-se, sobretudo, com a construção dos aeroportos centrais do Estado, como o Aeroporto Campo de Marte, o Aeroporto de Congonhas, o Aeroporto de Guarulhos/Cumbica e, principalmente, após o surgimento da empresa VASP.

O primeiro campo de aviação, o Aeroporto Campo de Marte, implantado na cidade de São Paulo, data de 1920, servindo durante muitos anos às atividades militares. Em 1933, o Aeroporto Campo de Marte passa a receber sua primeira linha com atividade civil que partia de São Paulo para as cidades de Campo Grande, Corumbá e 
Cuiabá, no Estado de Mato Grosso. Em 1936, uma enchente do Rio Tietê compromete as atividades aeroviárias no Aeroporto Campo de Marte ${ }^{32}$, que passou suas operações para o Aeroporto de Congonhas, adiantando as construções do novo aeroporto na cidade de São Paulo (FOUQUET, 2008).

Em 12 de abril de 1936, integrando um ambicioso plano de desenvolvimento urbanístico, crescimento e integração urbana, a empresa Auto-Estradas S.A. construiu um campo de pouso em uma área praticamente desabitada em São Paulo, local onde hoje está localizado o Aeroporto de Congonhas. Os anos de 1940 marcaram uma mudança de administração significativa para o desenvolvimento do Aeroporto de Congonhas, quando o Estado firmou um contrato com o DAC e obteve a concessão para explorar o aeroporto por 25 anos.

O Governo do Estado, com vistas à consolidação da nova empresa aérea VASP, adquiriu a área e ampliou suas instalações, transformando o campo de pouso no maior e mais movimentado aeroporto do Brasil e da América Latina: o Aeroporto de Congonhas. Fouquet (2008) alega que o Aeroporto de Congonhas representava o que de mais moderno podia-se construir em termos de aeroporto, e desempenhou e desempenha importante papel na estruturação do sistema aeroviário brasileiro. Revela, ainda, que, entre os anos de 1946 a 1958, o Aeroporto de Congonhas aumentou quatro vezes os números registrados na movimentação de aeronaves, cinco vezes o número de passageiros que embarcavam e desembarcavam no aeroporto e mais de quinze vezes a tonelagem de carga transportada.

Esses fluxos aéreos aumentaram nos anos seguintes, diante da política adotada pelos governantes paulistas ${ }^{33}$ (NEGRI, 1988) que, no intuito de resolver problemas urbanos da metrópole paulista, incentivou a desconcentração industrial para o interior, favorecendo, assim, o aumento da fluidez territorial.

\footnotetext{
${ }^{32}$ Atualmente, o Aeroporto Campo de Marte atende à aviação em geral (não regular), como aviões executivos, escolas de pilotagem etc., além de abrigar a maior frota de helicópteros do Brasil. Em 2006, foram registrados 85 mil pousos e decolagens, com 170 mil passageiros embarcados e desembarcados (FOUQUET, 2007).

${ }^{33}$ De acordo com Negri (1988), a desconcentração industrial no Estado de São Paulo foi incentivada mediante as políticas de Governo do Estado. Embora tenham sido desenvolvidas em diversas escalas e de acordo com interesses particulares desencadeados em diferentes momentos do processo de industrialização paulista, podemos destacar os principais Governos que tiveram papel singular na intensificação de tal iniciativa: Abreu Sodré (1967-1971), Laudo Natel (1971-1975), Paulo Egydio Martins (1975-1978), Paulo Salim Maluf e José Maria Marin (1979-1983), Franco Montoro (1983-1987), Orestes Quércia (1987-1991) entre outros.
} 
É importante destacar que, segundo Negri (1988), foi sob o comando do governador do Estado Paulo Egydio Martins que se criou a "Política de Desenvolvimento Urbano e Regional" do Estado de São Paulo, que almejava atuar sobre a organização territorial das cidades médias e pequenas, visando diminuir os desequilíbrios das regiões paulistas. No entanto, foi a partir dessas iniciativas que se intensificou uma "guerra dos lugares" que o autor denomina como a "ânsia de atrair indústrias", estimulando os prefeitos das cidades do interior no oferecimento de benefícios, isenções, incentivos fiscais etc., o que promoveu, em partes, o desenvolvimento regional. ${ }^{34}$

Desse modo, o crescimento dos fluxos aéreos ocorria em todos os segmentos, - internacional, nacional e regional, - iniciando uma leve demanda pelo modal no interior do Estado. O Aeroporto de Congonhas representava o cenário de maior atuação para as empresas aéreas de todos os segmentos, devido a sua localização na metrópole paulista, sua infraestrutura, que constantemente era ampliada e melhorada, desde as pistas de pouso até os terminais de passageiros e, também, por caracterizar-se como o principal $h u b$ do país na interligação com pontos estratégicos do território estadual e nacional.

Nos anos de 1980, a administração do aeroporto foi desligada do Governo do Estado, que estava sob gestão do DAESP, passando para a INFRAERO, ligada ao Ministério da Aeronáutica.

Atualmente, o Aeroporto de Congonhas compreende um dos mais movimentados sistemas aeroviários brasileiros e, juntamente com o Aeroporto de Guarulhos/Cumbica, apresenta o maior número de passageiros embarcados e desembarcados, em comparação com os demais Estados da Federação, como demonstrado no Gráfico 2.

\footnotetext{
${ }^{34}$ Negri (1988) argumenta que a interiorização das indústrias do Estado de São Paulo trouxe em conjunto problemas relacionados à degradação do meio ambiente, o agravamento dos problemas de transportes urbanos, de habitação e saneamento básico, o aumento da favelização e da criminalidade.
} 
Gráfico 2- Vinte aeroportos brasileiros com maior movimentação de passageiros no ano de 2007

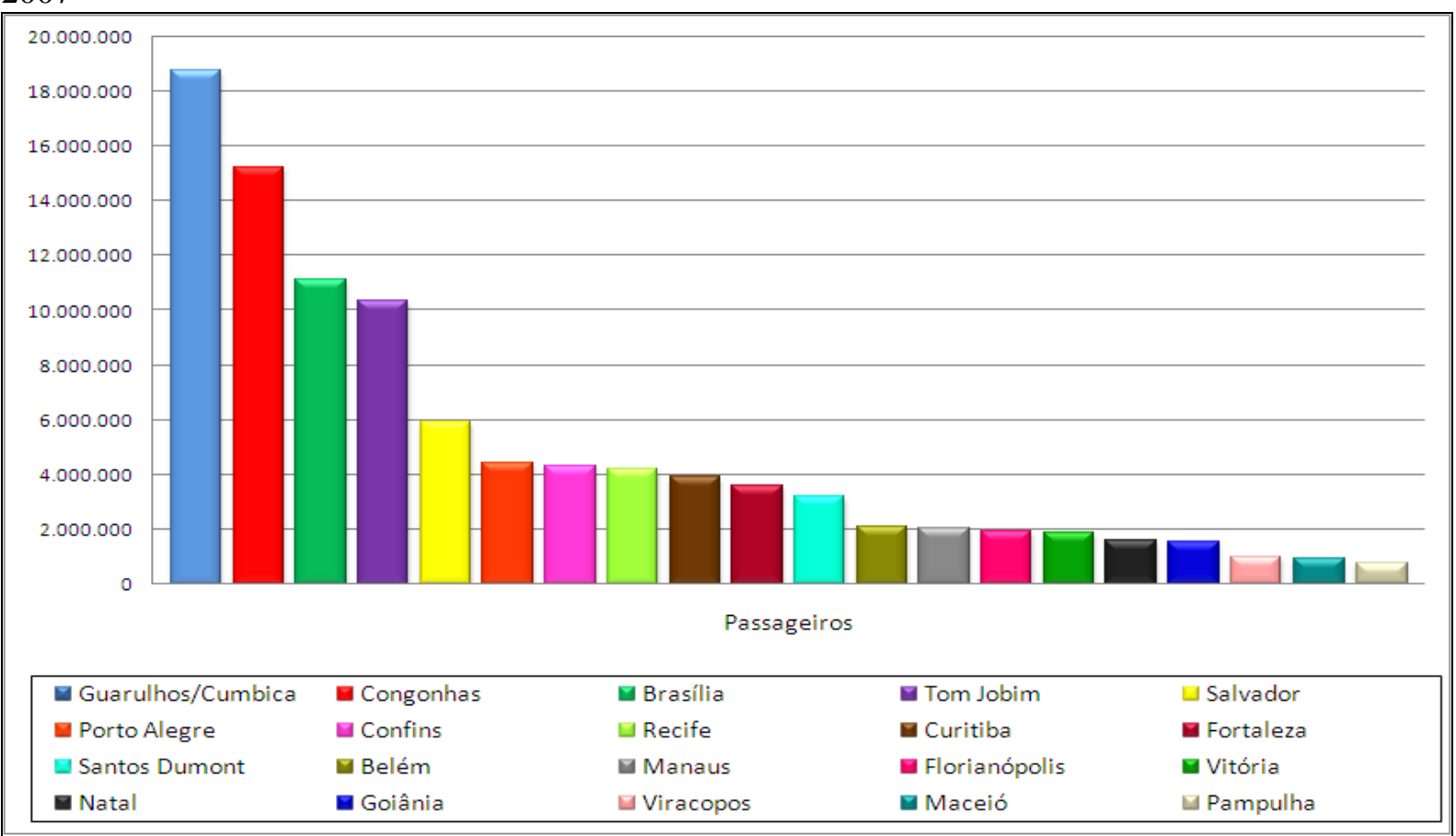

Fonte: INFRAERO, 2008,

Org.: Camilo Pereira, 2009

A particularidade do Aeroporto de Congonhas baseia-se no fato de o mesmo ser o principal aeroporto do Estado e $h u b$ nacional, bem como destino principal ou escala da maioria das rotas nacionais e regionais. De acordo com a INFRAERO, o Aeroporto de Congonhas recebe cerca de um avião por minuto, em razão da quantidade de alocação de $\operatorname{slots}^{35}$. A Tabela 4 representa a movimentação aérea no Aeroporto de Congonhas, da década de 1940 ao ano de 2007, elucidando sua expansão no número de passageiros transportados e no número de aeronaves que pousaram e decolaram no mesmo período. Os dados representam numericamente a expressividade do Aeroporto de Congonhas para a economia do Estado de São Paulo.

Tabela 4 - Evolução do Tráfego no Aeroporto de Congonhas (1941 - 2007)

\begin{tabular}{c|c|c}
\hline Anos & Passageiros & Aeronaves \\
\hline $1941-1950$ & 3.394 & 290,3 \\
\hline $1951-1960$ & 12.819 & 872,9 \\
\hline $1961-1970$ & 13.023 & 648,1 \\
\hline $1971-1980$ & 40.636 & 1111,9 \\
\hline $1981-1990$ & 40.862 & 1083,0 \\
\hline $1991-2000$ & 54.863 & 1591,4
\end{tabular}

35 Slots são espaços físicos e temporários autorizados para decolagem e aterrissagem de aeronaves (SALGADO, 2009). 
\begin{tabular}{c|r}
\hline $2001-2007$ & 100 \\
\hline Fonte: DAC (vários anos); FOUQUET, 2008
\end{tabular}

Org.: Camilo Pereira, 2009

Embora represente economicamente um dos aeroportos que mais gera fluxos de passageiros, o Aeroporto de Congonhas possui, hoje, um sistema aeroportuário extremamente limitado, o que tem gerado críticas sobre sua funcionalidade. A limitação física é oriunda das condições expansivas da cidade de São Paulo que, ao longo dos anos, chegaram às extremidades do aeroporto, impedindo, atualmente, maiores instalações e melhorias infraestruturais que proporcionariam viabilidade ao aumento de voos com destino e escala no local.

Situado em meio a uma área intensamente ocupada e urbanizada, a situação de crise do Aeroporto de Congonhas agravou-se após o acidente, em 17 de julho de 2007, com o avião AIRBUS da TAM Linhas Aéreas, que causou grande contestação sobre as condições infraestruturais do aeroporto, alarmando-se até sobre sua desativação ${ }^{36}$. Diversas análises arquitetônicas já foram mencionadas como forma de viabilizar as condições de pouso e decolagem e a movimentação de cargas e passageiros no Aeroporto de Congonhas, como, por exemplo, a verticalização do aeroporto. No entanto, o fato é que sua questão infraestrutural tem causado transtornos e incoerências técnicas. A Tabela 5 ilustra as atuais condições de infraestrutura do Aeroporto de Congonhas e os valores mínimos recomendados por agências internacionais.

Tabela 5 - Restrições físico-operacionais no Aeroporto de Congonhas - 2008

\begin{tabular}{c|c|c|c}
\hline Subsistema & Parâmetro & Congonhas & Recomendado \\
\hline $\begin{array}{c}\text { Pista de pouso e } \\
\text { decolagem }\end{array}$ & Extensão & $\begin{array}{c}1.640 \times 45 \mathrm{e} \\
1.345 \times 45 \mathrm{~m}\end{array}$ & $3.000 \mathrm{~m}$ \\
\hline Pátio de Aeronaves & $\begin{array}{c}\text { Afastamento mínino entre } \\
\text { aeronave }\end{array}$ & $3 \mathrm{~m}$ & $7,5 \mathrm{~m}$ \\
\hline Terminal de Passageiros & $\begin{array}{c}\text { Área/passageiro na hora de } \\
\text { pico em embarque }\end{array}$ & $3 \mathrm{~m}^{2}$ & $14 \mathrm{~m}^{2}$ \\
\hline $\begin{array}{c}\text { Estacionamento de } \\
\text { Veículos }\end{array}$ & Vagas por dia & 1.518 & 2.300 \\
\hline
\end{tabular}

Fonte: FOUQUET, 2008

Org.: Camilo Pereira, 2009

\footnotetext{
${ }^{36}$ O Aeroporto de Congonhas perdeu mais de 2 milhões de passageiros (20,78\%) na comparação de janeiro a julho de 2007 com o mesmo período do ano de 2008, época na qual foram impostas várias restrições às operações aéreas no local, depois do acidente com o avião da TAM, que causou a morte de 199 passageiros. Foram 7.978 milhões de passageiros atendidos este ano, contra 10.072 milhões no ano passado (ABEATAR, 2008).
} 
Desde a década de 1940, o Aeroporto de Congonhas já apresentava um crescimento do tráfego aéreo que requeria a construção de um novo aeroporto, como alternativa para o "descongestionamento" da capital. Em tal contexto cresciam as expectativas e especulações sobre a construção do Aeroporto de Viracopos, na cidade de Campinas. Em 1960, inaugurou-se o Aeroporto de Viracopos, que continuou servindo o mercado paulista. Não obstante, Viracopos não significou o "descongestionamento" da capital. A demanda era composta pela região de Campinas, o que não acarretou a diminuição dos passageiros que utilizavam Congonhas.

Em função da distância de aproximadamente $100 \mathrm{~km}$ entre o Aeroporto de Viracopos e São Paulo e da falta de um sistema de transporte público (fatores estes que acarretavam tempo e substanciais despesas), o uso do terminal aéreo nunca conseguiu agradar domiciliados da capital (FOUQUET, 2007, p. 4).

Em 1985, a inauguração do Aeroporto de Guarulhos/Cumbica trouxe novas expectativas para o setor aéreo do Estado de São Paulo. A construção do aeroporto teve como um dos principais objetivos o "desafogo" do Aeroporto de Congonhas. De acordo com Fouquet (2008), o Aeroporto de Guarulhos/Cumbica reorientou o setor de transporte aéreo no Estado de São Paulo. Todavia, por orientação do Ministério da Aeronáutica na V CONAC, o Aeroporto de Congonhas voltou a receber contingente de voos superior ao de Guarulhos.

O Aeroporto de Guarulhos/Cumbica possui capacidade instalada superior ao Aeroporto de Congonhas, mas sua capacidade não é toda utilizada, sendo deslocados voos para Congonhas que poderiam ser recebidos por Guarulhos. De acordo com a própria legislação, o Aeroporto de Guarulhos/Cumbica apresenta dificuldades de acesso rodoviário e a necessidade de promover ligações rápidas entre os centros vitais da economia nacional.

Segundo Fouquet (2007), o Plano Diretor do Aeroporto Internacional de Guarulhos/Cumbica, elaborado em 1981, previa quatro terminais, cada um para 7,5 milhões de passageiros, resultando em capacidade total de 7,5 x $4=30$ milhões de passageiros/ano. Previam-se, ainda, duas pistas principais, além de uma terceira, esta destinada, em princípio, à aviação regional, com 1.500 metros de comprimento. Juntamente às duas pistas principais, o primeiro terminal foi inaugurado em 1985 e o segundo, em 1993. Em 1998, foi registrado movimento "pico" de 14,5 milhões de passageiros, somente superado a partir de 2005. 
A inoperância governamental no funcionamento e na expansão do Aeroporto de Guarulhos/Cumbica implicou em prejuízos para o sistema de transporte aéreo paulista e, consequentemente, para o segmento regional. Para Fouquet (2008), a licitação para construção do terceiro terminal de passageiros e da terceira pista de Guarulhos, prevista para ser realizada no ano 2000, inexplicavelmente não ocorreu. Foi realizada somente uma pequena ampliação dos terminais 1 e 2 , elevando sua capacidade teórica para 16 milhões de passageiros/ano. Em resumo, durante os últimos 15 anos, Guarulhos, o mais movimentado aeroporto internacional da América do Sul, não recebeu aumento de capacidade significativo.

Concomitante à expressividade dos aeroportos centrais do Estado de São Paulo, encontra-se, também, como um marco decisivo para o desenvolvimento da aviação comercial brasileira e, sobretudo, paulista, a criação da VASP. A VASP foi criada no ano de 1933 e inaugurou no Estado a maior empresa pública de aviação comercial brasileira. A empresa era composta majoritariamente de capital do Governo do Estado de São Paulo. Em 1990, o controle acionário passou ao setor privado, por meio de um leilão no qual o Consórcio Voe Canhedo, composto pelo Grupo Canhedo e por funcionários da VASP, adquiriram a empresa por US\$44.000.000, o que expressava $60 \%$ das ações ordinárias da VASP. Nos anos 2000, a empresa começou a declarar sinais de falência e, em 2005, entrou em processo de recuperação judicial ${ }^{37}$.

Mesmo em decorrência da história da empresa VASP, compreende-se seu importante papel no desenvolvimento do setor de transporte aéreo em São Paulo e, por conseguinte, no Estado. A VASP representava a maior empresa de transporte aéreo no país. Seu destaque baseava-se, principalmente, na frota existente. Em pouco tempo de existência a VASP já possui a maior frota de turbo-hélices da América Latina.

\footnotetext{
37 A título de informação, às vésperas de sua privatização, a empresa VASP possuía uma frota de 32 aeronaves, 7.300 funcionários e era a segunda maior empresa do país (PORTAL DA VASP, 2008).
} 
Foto 2 - Aviões da VASP no Aeroporto de Congonhas - 1960

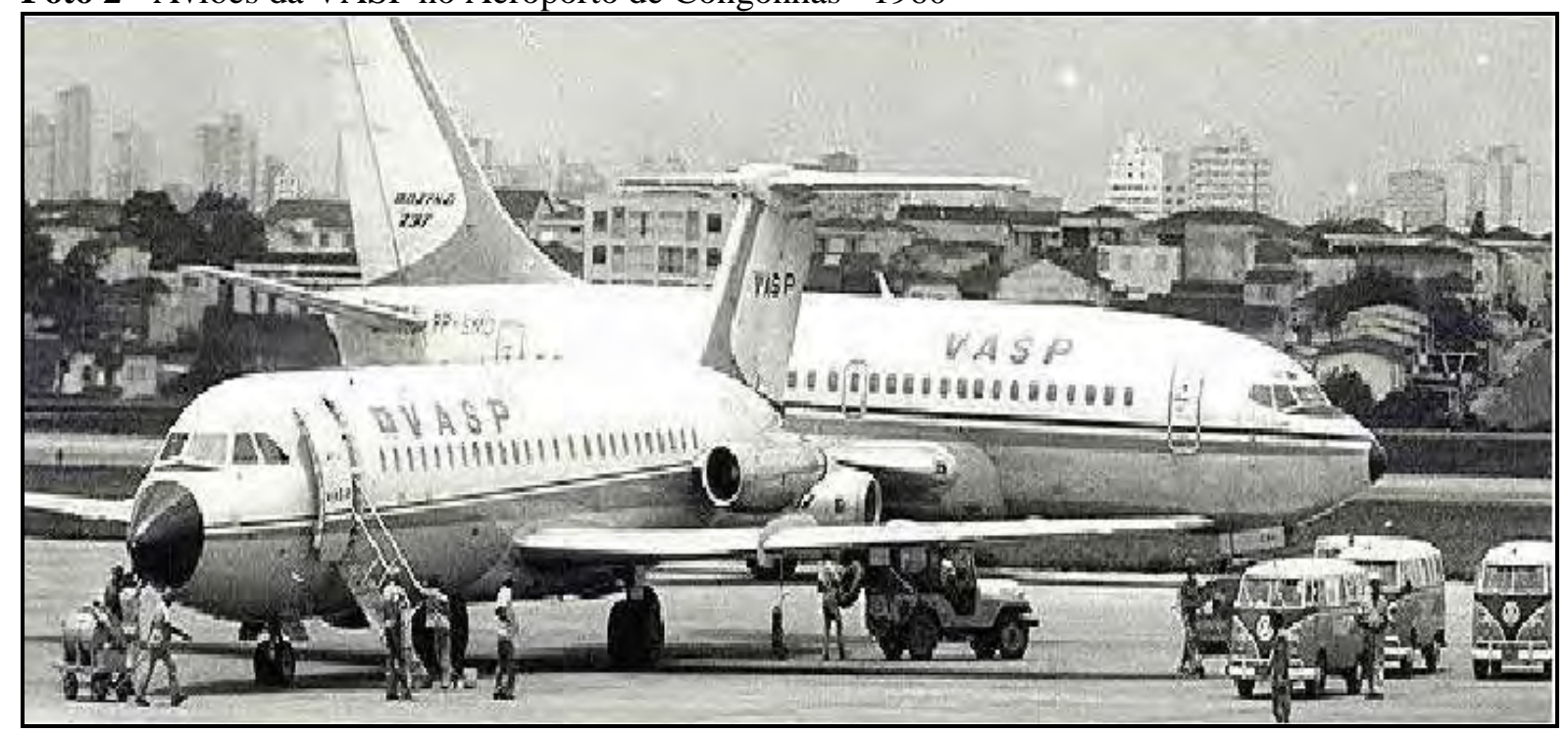

Fonte: Arquivo Revista Flap Internacional, 2007

A empresa iniciou suas operações com duas rotas: São Paulo-São José do Rio Preto, com escala em São Carlos, e São Paulo-Uberaba, com escala em Ribeirão Preto. Cada uma fazia três frequências semanais em cada rota. Eram os primeiros voos regulares da empresa que, em 1936, inaugurou sua primeira linha de São Paulo ao Rio de Janeiro, com os dois novos aviões, batizados de "Cidade de São Paulo" e "Cidade do Rio de Janeiro", que entraram logo em serviço com um voo diário em cada sentido. A viagem durava 1 hora e 40 minutos; depois foi reduzida para 1 hora e 15 minutos. Estava, assim, inaugurada a ponte-aérea Rio-São Paulo.

As linhas executadas pela empresa aumentavam, inclusive, no Estado. Com isso, expandia-se o setor de transporte aéreo no território paulista, intensificando a implementação do novo segmento para o setor, o transporte aéreo regional.

O desenvolvimento do transporte aéreo em cidades do interior do Estado deu-se seguindo os mesmos rumos que se desenvolveu o modal rodoviário, resultado também da desconcentração produtiva. Todavia, esse processo não ocorreu aleatoriamente, definindo as cidades que corresponderiam ao desenvolvimento do setor aéreo. Este se realizou concomitante aos desdobramentos da aviação comercial no cenário nacional e estadual e em razão dos aeroclubes existentes em algumas cidades do Estado, fato este que fomentou a aviação e favoreceu a instalação dos aeroportos. Nesse sentido, as cidades que atraíram o desenvolvimento do transporte aéreo referiam-se, também, àquelas que despontavam economicamente no interior do Estado de São Paulo, 
tais como as cidades de Araçatuba, Bauru, Marília, Presidente Prudente, Ribeirão Preto e São José do Rio Preto.

\subsubsection{Desconcentração produtiva e integração territorial: causa/efeito da contribuição do transporte aéreo regional}

O desenvolvimento de um novo segmento do transporte aéreo paulista constituiu um processo de articulação no Estado, antes processado pelo transporte ferroviário e, posteriormente e de forma ainda predominante, pelo modal rodoviário. A necessidade de um novo e mais eficiente modal que interligasse o território com mais rapidez provocou a reorganização dos meios de transportes, e intensificou a concorrência entre os modais, sobretudo entre o rodoviário e o aéreo.

A necessidade de circulação no território demanda o aperfeiçoamento dos meios de transporte, e é nesse sentido que o setor aéreo torna-se relevante na fluidez territorial, como modal operante na velocidade das ações no espaço. Silveira (2009a), ao discorrer sobre a ampliação da velocidade da tecnologia, assevera que "a tecnologia se materializa nos sistemas de movimentos (redes técnicas e meios de transportes) e de comunicações". Para o autor, essa relação tecnológica releva a complementaridade entre as redes técnicas, os meios de transportes e os fluxos. Nessa análise, Lamoso (2009, p. 43) argumenta que o "desenvolvimento e a aplicação da técnica condicionam as transformações num espaço concreto, constituindo uma rede de fixos e de fluxos".

O transporte aéreo revela-se como um meio pelo qual a sociedade mantém suas relações sociais e econômicas, processando o setor como fator de mobilidade material e imaterial no espaço onde o capital se reproduz.

Consequência do constante processo de transformações sócioespaciais globais e, em razão do padrão de acumulação capitalista, que se tornava latente, as novas formas de circulação mais velozes e flexíveis, confirmou a necessidade da mobilidade territorial em âmbito regional no Estado de São Paulo. A necessidade de uma maior e melhor articulação territorial que integrasse os diversos eixos industriais do Estado de São Paulo fez-se presente e as cidades paulistas desenvolviam-se articuladas, todavia independentes, numa conjuntura espacial que impunha a integração econômica via transportes. 
Nesse sentido, Corrêa et al (1977, p. 33 ) assevera que cada “cidade não é apenas uma forma, mas um organismo que se desenvolve por meio de uma economia "básica" urbana capaz de mantê-la ligada aos outros centros do sistema". Para tanto, observa-se que é a partir de vários relacionamentos que se dão essas ligações, sobretudo pelos transportes.

O processo de transformação e de utilização de um novo modal que articulasse territorialmente o Estado acompanhou a desconcentração urbano-industrial no Estado de São Paulo (LENCIONI, 1994). Nesse contexto, Negri (1988) enfatiza as determinações políticas do Estado de São Paulo que, basicamente, coordenaram o desenvolvimento de vários setores, dentre eles o de transportes:

As políticas espaciais adotadas pelo Governo estadual também exerceram influência no processo de descentralização, notadamente pelos investimentos em grandes e modernas rodovias - Castelo Branco, Bandeirantes e Imigrantes - e recuperação e ampliação (terceiras faixas) em outras de importância semelhante a Anhanguera e Washington Luiz, da recuperação da malha viária estadual e da notável rede de estradas vicinais (...). Essa política aproximou as distâncias entre a metrópole e o interior, diminuindo os custos de transportes e alargando o horizonte da localização industrial (NEGRI, 1988, p. 31).

A reestruturação urbano-industrial rumo ao interior paulista processou-se a partir da década de 1970, iniciando no Estado de São Paulo uma dispersão das atividades industriais e de consumo do aglomerado metropolitano, com as indústrias estruturando-se em direção aos traçados das principais vias de transporte rodoviário que partiam da capital paulista com destino ao interior do Estado.

Enquanto houve desconcentração da produção e do consumo para o interior do Estado de São Paulo, fortaleceu-se na metrópole a centralização da gestão, aumentando com isso a necessidade de conexão entre a metrópole e o interior, já que há a necessidade da gestão e da produção estarem interligadas. Isso aumentou a demanda pelo modal aéreo.

Silveira (2009a) analisa o processo de desconcentração urbano-industrial destacando que:

No início do século XXI, a necessidade de ampliação dos circuitos espaciais de produção e dos círculos de cooperação no espaço pressionou a fluidez do território. As principais reestruturações econômicas do território ocorreram na "Região Concentrada", destacadamente, São Paulo [...]. No Estado de São Paulo, a base da reestruturação econômica, partiu da metrópole e atingiu, a partir dela, 
as cidades médias do interior - as próximas, num raio de 150 quilômetros, e as mais afastadas - formando eixos de desenvolvimento. A reestruturação iniciou-se na década de 1970, com a desconcentração industrial, ocorrida a partir da metrópole paulista e, ao mesmo tempo, foi acompanhada por uma concentração da gestão na metrópole.

Nessa perspectiva evidenciada pelo autor sobre a centralização da gestão na metrópole e a desconcentração das atividades produtivas industriais no interior, notamos que é inerente para a compreensão do processo evolutivo da aviação aérea em São Paulo sua vinculação ao processo financeiro, econômico e social do Estado.

Negri (1988), ao retratar as políticas de desconcentração industrial, bem como seu processo de interiorização no Estado de São Paulo, destaca que o incentivo do Estado e do Governo Federal foi crucial para que tal processo se confirmasse. Os efeitos gerados pelos estímulos do Poder Público foram verificados em cidades como Ribeirão Preto, que recebeu a instituição do Proálcool (1975) e que consolidou na cidade e em sua região de influência imediata o desenvolvimento da indústria de bens de capital.

Sposito (2007) e Lencioni (1994) consideram que a reestruturação urbanoindustrial do Estado de São Paulo impulsionou a desconcentração, mas não a descentralização da gestão das atividades; os mesmos alegam, ainda, que, se por um lado, a região metropolitana perdeu unidades fabris para o interior, caracterizando um processo de desconcentração, por outro, esse processo seguiu a lógica capitalista de caráter transnacional e configurou um redirecionamento das unidades produtoras para o interior do Estado. Com isso, a tomada de decisões concentrou-se na capital, onde estão situados os principais nós das redes de comunicações e os serviços necessários para se desempenhar papel de comando nas diversas escalas. É neste sentido que a desconcentração urbano-industrial e a centralização das atividades econômicas em São Paulo intensificam os fluxos de passageiros do interior em direção à metrópole paulista e vice-versa.

Beltrão Sposito (2007) argumenta que a desconcentração e descentralização têm restabelecido a preferência de empresas quando da escolha de sua instalação em determinados lugares. Para a autora, o conjunto de mudanças produzidas pelo processo de concentração e centralização econômicas, com desconcentração espacial das atividades produtivas e de consumo, tem repercussão direta na função desempenhada 
por cada cidade. Assim, o interior do Estado de São Paulo têm sido escolhido como ponto de desconcentração das atividades produtivas e de expansão das redes, intensificando o processo de integração territorial e de desenvolvimento econômico regional.

A reestruturação urbano-industrial no Estado de São Paulo provocou, de acordo com Lencioni (2003), a cisão territorial entre produção e gestão que redesenhou as proximidades e distâncias entre os territórios, a partir de redes territoriais que constituem uma entre as várias estratégias territoriais do capital. Essa cisão territorial é um aspecto da desconcentração do capital em determinados territórios, que não se restringe apenas à capital paulista. No entanto, a vinculação com a capital paulista é inerente a todo processo de desenvolvimento econômico regional. Compreendemos, a partir dessas considerações, o fundamental papel da conectividade aérea entre as cidades destacadas e São Paulo. Diante da reestruturação produtiva das indústrias e da maior interdependência entre os territórios, o Governo Estadual investiu nas ligações entre o interior e a capital, como forma de encurtar as distâncias; para isso efetuou melhorias em rodovias, portos e aeroportos (NEGRI, 1988).

Desta forma, analisamos que o processo de desconcentração urbanoindustrial foi diferenciado em cada cidade. No entanto, a análise apontada refere-se ao direcionamento geográfico que esse processo trouxe à luz, baseadas nas combinações geográficas (CHOLLEY, 1964) características de cada centralidade urbana. Esse processo revelou-se mediante os eixos de circulação que a desconcentração das indústrias provocou no Estado de São Paulo, configurando os nós das redes do setor aéreo regional do Estado.

Ao considerarmos as combinações geográficas (CHOLLEY, 1964) que promoveram o desenvolvimento de determinados territórios do espaço paulista, compreendemos que alguns fatores possibilitaram a dinamicidade territorial, o que contribuiu, posteriormente, para a integração e articulação do Estado de São Paulo.

Para Cholley (1964), o caráter geográfico das combinações perfaz-se a partir das mudanças processadas no meio e que implicam uma noção de estabilidade, de duração ou de renovação periódica. A cada mudança, novos meios são verificados, isto é, novas combinações são criadas, pois se teceu uma nova "atmosfera", um novo meio 
ao qual se adaptaram as várias combinações elaboradas nos diversos domínios da atividade humana.

Quando verificamos as combinações geográficas expressas por Cholley (1964), no plano empírico da questão analisada, ou seja, do transporte aéreo, nota-se que as transformações ocorridas no espaço paulista trouxeram novos contextos de análise para o desenvolvimento dos meios de transportes em determinadas cidades do Estado. Em outras palavras, a evolução do transporte aéreo regional processou transformações que reordenaram, do ponto de vista da integração territorial e dos impactos socioespaciais, a utilização dos modais para articulação do circuito espacial de circulação.

Nesse sentido, verifica-se que o surgimento do segmento de transporte aéreo em âmbito regional possibilitou uma nova combinação de interações espaciais e integração entre os territórios, a partir dos fluxos aéreos, que cooperou para a formação de uma rede urbana ${ }^{38}$ especializada e bem articulada, a qual detém, de acordo com Ramos (1998), uma configuração urbana bastante complexa e multidimensionada, com a maior densidade técnica em seu território:

São Paulo possui uma rede urbana relativamente bem estruturada ao longo do seu território, com um número expressivo de cidades médias, além de abrigar uma grande região metropolitana, liderada por uma cidade mundial que comanda a área mais dinâmica do país, assim considerada por concentrar muitas organizações industriais, comerciais e de serviços (RAMOS, 1998, p. 82).

A partir das considerações de Ramos (1998) sobre a dinâmica territorial paulista, verifica-se que sua articulação exposta por redes ultrapassa a escala do regional e configura uma rede integrada do Estado com demais porções do território brasileiro, resultado, sobretudo do que Santos (2001) denomina como "densidade técnica" que o Estado de São Paulo comporta. Assim, embora este trabalho não analise as ligações aéreas fora do Estado de São Paulo, é nítida a articulação aérea paulista que compreende rotas para todos os Estados da Federação, fomentando ainda mais a integração territorial no país.

Nesse contexto, de um espaço complexo e de múltiplas combinações geográficas, como é o Estado de São Paulo, que ao tratarmos o transporte aéreo

\footnotetext{
${ }^{38}$ Como forma de tornar precisa a alegação sobre a rede urbana paulista, considera-se que a complexa organização urbana deste Estado decorre de um longo processo histórico de consolidação de sua rede, estreitamente vinculado à divisão do trabalho estabelecida nessa área (RAMOS, 1998).
} 
regional, observamos sua dinamicidade no que tange ao processamento das interações espaciais, bem como no desenvolvimento do interior do Estado. Desta forma, vê-se que os centros urbanos aqui analisados, além de concentrarem as atividades produtivas, correspondem também a territórios que têm impulsionado e atraído diversos setores econômicos, como o aéreo, e empresas, como, por exemplo, as de transporte aéreo ${ }^{39}$.

No entanto, mesmo consubstanciado a partir de sua densidade técnica especializada que tem promovido o desenvolvimento setorial, o Estado de São Paulo tem demonstrado, assim como os demais segmentos econômicos, que a gestão e o planejamento estão articulados ao crescimento do transporte aéreo regional. Nesse sentido, destacamos que São Paulo é um dos únicos Estados da Federação que possui um órgão político-administrativo que controla o setor aéreo em âmbito estadual. Desse modo, o Estado orientado a partir de políticas de desenvolvimento do setor de transporte aéreo coopera juntamente ao Ministério da Defesa para a eficácia na qualidade do serviço aéreo, mesmo que estes tenham apresentado, recentemente, conflitos em termos de política, gestão e controle na qualidade do serviço disponibilizado à sociedade.

\subsection{Gestão e política de desenvolvimento do transporte aéreo regional no Estado de São Paulo}

O Brasil é o $4^{\circ}$ maior mercado doméstico mundial de aviação comercial, cobrindo uma vasta área e com uma população de cerca de 184 milhões de pessoas em 2007, de acordo com o Instituto Brasileiro de Geografia e Estatística (IBGE). A ponte aérea entre as cidades de São Paulo e o Rio de Janeiro é uma das mais movimentadas. A aviação civil brasileira segue os mais elevados padrões de segurança do mundo. $\mathrm{O}$ Brasil é classificado como um país que contempla a Categoria 1 de padrões de segurança de voo estabelecidos pela OACI, que é a mesma classificação atribuída aos Estados Unidos e ao Canadá (ANAC, 2008).

O mercado de linhas aéreas regulares no Brasil compreende dois principais tipos de passageiros: passageiros em viagens de negócios e passageiros em viagens de lazer. Passageiros em viagens de negócios geralmente dão valor a fatores como frequência dos voos, confiabilidade, pontualidade, disponibilidade de voos diretos,

\footnotetext{
${ }^{39}$ Há, inclusive, cidades do Estado de São Paulo que são bases territoriais de empresas aéreas como, por exemplo, Ribeirão Preto, que abriga a companhia Passaredo Linhas Aéreas. Embora seja uma exceção, este é um caso em que a centralização da gestão localiza-se no interior e não na capital paulista.
} 
extensão da área servida e diferencial dos serviços. Passageiros em viagens de lazer geralmente dão mais importância aos preços e tendem a ser mais flexíveis ao programar suas viagens. O setor de viagens de negócios é o maior e mais lucrativo segmento do setor de transporte aéreo no Brasil. As viagens de negócios representaram aproximadamente $70 \%$ do total da demanda no Brasil para voos aéreos domésticos em 2007, número que é significativamente maior do que a proporção desse segmento na aviação civil internacional (RELATÓRIO TAM, 2007).

O mercado para aviação civil no Brasil apresenta um grande potencial, pois a maior parte da população ainda utiliza o transporte rodoviário. Com a redução no preço das tarifas apresentada ao longo dos últimos anos, existe um movimento de popularização do transporte aéreo como meio de deslocamento.

O transporte aéreo representa um setor econômico que abrange um conjunto de atividades complexas. Trata-se de um setor que contempla, entre diversos fatores, a regulação (técnica e econômica) e fiscalização, com capacidade intensiva em capital, mão-de-obra qualificada e tecnologia de ponta. Um setor que considera os principais acordos internacionais firmados com companhias de bandeiras estrangeiras, favorecendo a articulação do Brasil com demais países. O transporte aéreo é extremamente diversificado quanto ao estágio de desenvolvimento das companhias e, ainda, processa-se como um setor fornecedor de bens e serviços de elevado valor específico (BURLE, 2003).

Para a compreensão da gestão e política de desenvolvimento aeroviário do Estado de São Paulo, é imprescindível contextualizar o papel empreendido pela ANAC, pela INFRAERO e pelo DAESP, na promoção e no desenvolvimento do setor aéreo. Estes órgãos participam da gestão e do fomento ao crescimento do setor para utilização do mesmo por passageiros e cargas. Desta forma, a ANAC, a INFRAERO e o DAESP, em dimensões diferentes, são órgãos incumbidos do gerenciamento aeroviário, e são, igualmente, responsáveis pelos investimentos em infraestruturas, movimentação e, sobretudo, pela modernização que o transporte aéreo tem demandado para seu funcionamento.

A ANAC visa regular e fiscalizar as atividades de aviação civil, bem como adotar as medidas necessárias para o atendimento do interesse público no setor. Além disso, tem como compromisso incentivar e desenvolver a aviação civil, a infraestrutura 
aeroportuária do país. A INFRAERO e o DAESP ficam sob sua fiscalização, isto é, são órgãos que administram os aeroportos de acordo com as exigências legais do sistema aeroviário brasileiro, regido pela ANAC.

A INFRAERO é uma empresa pública nacional. Atua na administração de todos Estados da Federação. A empresa é vinculada ao Ministério da Defesa. Possui o controle dos maiores aeroportos brasileiros e alguns de pequeno porte, como aeroportos cuja função é representar a soberania nacional em áreas longínquas. De acordo com a empresa, seu controle está ligado a 67 aeroportos, 80 unidades de apoio à navegação aérea e 32 terminais de logística de carga.

Os aeroportos de administração da INFRAERO concentram aproximadamente $97 \%$ do movimento do transporte aéreo regular do Brasil. Além de passageiros, a empresa opera nos aeroportos equipados para funcionar como plataforma de helicópteros e outros cuja vocação está na logística de carga e de manuseio de mercadorias perigosas (INFRAERO, 2008).

A Lei $\mathrm{n}^{\circ}$ 5.862, de 12 de dezembro de 1972, constituiu a INFRAERO como empresa pública por intermédio dos atos do Presidente da República Emílio Garrastazu Médici, que concedeu providências à empresa junto aos órgãos responsáveis pela gestão do setor do transporte aéreo brasileiro.

Desta forma, a atuação da INFRAERO no Estado de São Paulo corresponde à administração dos principais aeroportos, ou seja, os de maior centralidade e aglomeração, localizados na cidade de São Paulo e no seu entorno, como elucidado na Tabela 6:

Tabela 6 - Aeroportos Administrados pela INFRAERO - 2008

\begin{tabular}{l|l|l}
\hline & \multicolumn{1}{|c|}{ Aeroportos } & \multicolumn{1}{c}{ Cidades } \\
\hline 1 & Aeroporto Internacional de Congonhas & São Paulo \\
\hline 2 & Aeroporto Internacional São Paulo/Guarulhos (Cumbica) & Guarulhos \\
\hline 3 & Aeroporto Internacional Campo de Marte & São Paulo \\
\hline 4 & Aeroporto Internacional de Viracopos & Campinas \\
\hline 5 & Aeroporto de São José dos Campos & São José dos Campos \\
\hline
\end{tabular}

Fonte: INFRAERO, 2008

Org.: Camilo Pereira, 2009

No que tange à administração estadual dos aeroportos do Estado, encontrase o DAESP, que se classifica como autarquia subordinada à Secretaria dos Transportes do Estado de São Paulo. No ano de 1952, por determinação da secretaria de Viação e 
Obras Públicas, criou-se a Diretoria de Aeroportos que, posteriormente, foi transformada em Departamento Aeroviário da Secretaria dos Transportes, tendo sido desmembrado em duas secretarias do Governo: Secretaria dos Transportes e Secretaria de Serviços e Obras Públicas.

Em 1966, foi criado o DAESP que tem a responsabilidade de administrar, manter e explorar 31 aeroportos públicos no interior do Estado de São Paulo.

Cabe ao DAESP, como já salientado, a administração dos aeroportos do interior do Estado de São Paulo, regulares e não-regulares, a saber:

Tabela 7 - Aeroportos Administrados pelo DAESP - 2008

\begin{tabular}{|c|c|c|}
\hline & Aeroportos & Cidades \\
\hline 1 & Aeroporto Estadual Paulino Ribeiro de Andrade & Andradina \\
\hline 2 & Aeroporto Estadual Dario Guarita & Araçatuba \\
\hline 3 & Aeroporto Estadual Bartolomeu Gusmão & Araraquara \\
\hline 4 & Aeroporto Estadual Marcelo Pires Halzhausen & Assis \\
\hline 5 & $\begin{array}{c}\text { Aeroporto Regional Avaré/Arandu Cmte. Luis } \\
\text { Gonzaga Luth }\end{array}$ & Avaré/Arandu \\
\hline 6 & Aeroporto Estadual Chafei Amsei & Barretos \\
\hline 7 & Aeroporto Estadual de Bauru & Bauru \\
\hline 8 & Aeroporto Estadual Bauru/Arealva & Bauru/Arealva \\
\hline 9 & Aeroporto Estadual Tancredo de Almeida Neves & Botucatu \\
\hline 10 & Aeroporto Estadual de Bragança Paulista & Bragança Paulista \\
\hline 11 & Aeroporto Estadual Campo do Amarais & Campinas/Amarais \\
\hline 12 & Aeroporto Estadual Moliterno de Dracena & Dracena \\
\hline 13 & Aeroporto Estadual Tenente Lund Presetto & Franca \\
\hline 14 & Aeroporto Estadual Antônio Ribeiro Nogueira & Itanhaém \\
\hline 15 & Aeroporto Estadual Cmte. Rolim Adolfo Amaro & Jundiaí \\
\hline 16 & Aeroporto Estadual Gov. Lucas Nogueira Garcez & Lins \\
\hline 17 & Aeroporto Estadual Frank Miloye Milenkowichi & Marília \\
\hline 18 & Aeroporto Estadual de Ourinhos & Ourinhos \\
\hline 19 & Aeroporto Estadual Dr. Ramalho Franco & Penápolis \\
\hline 20 & Aeroporto Estadual Pedro Morganti & Piracicaba \\
\hline 21 & Aeroporto Estadual Geraldo Moacir Bordon & Presidente Epitácio \\
\hline 22 & Aeroporto Estadual de Presidente Prudente & Presidente Prudente \\
\hline 23 & Aeroporto Estadual Dr. Leite Lopes & Ribeirão Preto \\
\hline 24 & Aeroporto Estadual Francisco Pereira Lopes & São Carlos \\
\hline 25 & Aeroporto Estadual Prof. Eriberto Manoel Ribeiro & São José do Rio Preto \\
\hline 26 & Aeroporto Estadual Nelson Garófalo & São Manuel \\
\hline 27 & Aeroporto Estadual de Sorocaba & Sorocaba \\
\hline 28 & Aeroporto Estadual José Vicente Faria Lima & Tupã \\
\hline 29 & Aeroporto Estadual Gastão Mesquita & Ubatuba \\
\hline 30 & Aeroporto Estadual de Urubupungá & Urubupungá \\
\hline 31 & Aeroporto Estadual Domingos Pignatari & Votuporanga \\
\hline
\end{tabular}

Fonte: Revista Aeroportos do DAESP, 2006

Org.: Camilo Pereira, 2009 
No que concerne à diferenciação entre os órgãos incumbidos da administração aeroportuária nacional, ou seja, entre a INFRAERO e o DAESP, destacamos como fundamental a obtenção de recursos para investimentos em infraestrutura. Em outras palavras, significa dizer que a INFRAERO, enquanto empresa federal dispõe de recursos financeiros mais intensos do que o DAESP, departamento estadual, o que lhe confere uma melhor administração e distribuição de verbas para investimentos em aeroportos.

A infraestrutura tem importante função na organização da circulação aérea e na produção da capacidade de operacionalização, devido ao fato de caracterizar o potencial aeroviário de cada cidade. Em dimensões comparativas, as cidades aeroviárias com os aeroportos de melhor centralidade, como os localizados nos grandes centros e nos seus entornos, possuem melhores condições infraestruturais, como, por exemplo, a capacidade da área do sítio aeroportuário, pátio para aeronaves, condições e tamanho de pista, área e capacidade do terminal de passageiros, estacionamentos, número de balcões de check-in e de empresas aéreas etc.

Embora a distribuição de verbas para os aeroportos da INFRAERO e do DAESP não sejam passíveis de comparação, por serem órgãos de entidades diferentes, os investimentos em infraestrutura dos aeroportos são totalmente discrepantes em ordem de valores. Observa-se a maior amplitude de investimentos em modernização dos aeroportos, capacidade de aeronaves, passageiros, cargas etc., em aeroportos sob gestão da INFRAERO. Esse maior número de investimentos nos aeroportos da INFRAERO se dá, principalmente, devido ao fato de tais aeroportos constituírem os elos de interligação entre a metrópole paulista e o território nacional e, também, por caracterizarem-se como aeroportos de fluxos internacionais.

As tabelas 8 e 9 indicam os complexos aeroviários da INFRAERO e do DAESP, considerando sua capacidade aeroportuária, isto é, dimensões de pista, capacidade do terminal de passageiros e capacidade do estacionamento para automóveis. Observa-se substancial discrepância entre os aeroportos da capital e do interior. 
Tabela 8 - Complexo aeroviário de aeroportos da INFRAERO - 2008

\begin{tabular}{l|r|r|r}
\hline $\begin{array}{c}\text { Aeroportos } \\
\text { (cidades) }\end{array}$ & $\begin{array}{c}\text { Dimensões } \\
\text { de pista } \\
\text { (metros) }\end{array}$ & \multicolumn{1}{c|}{$\begin{array}{c}\text { Terminal de pax } \\
\text { (unidade/dia) }\end{array}$} & $\begin{array}{c}\text { Estacionamento } \\
\text { carros } \\
\text { (vagas) }\end{array}$ \\
\hline Campinas/Viracopos & $3.240 \times 45$ & 2.000 .000 & 810 \\
\hline Guarulhos/Cumbica & $3.700 \times 45 \mathrm{e}$ & 8.250 .000 & 3.098 \\
& $3.000 \times 45$ & 90.000 & 49 \\
\hline São José dos Campos* & $2.676 \times 45$ & 45.000 & 1.518 \\
\hline Campo de Marte* & $1.600 \times 45$ & 12.000 .000 & \\
\hline Congonhas & $1.640 \times 45 \mathrm{e}$ & & \\
& $1.345 \times 45$ & & \\
\hline
\end{tabular}

* Não opera voos regulares

Fonte: INFRAERO, 2008

Org.: Camilo Pereira, 2009

Tabela 9 - Complexo aeroviário de aeroportos do DAESP - 2008

\begin{tabular}{l|r|r|r}
\hline $\begin{array}{c}\text { Aeroportos } \\
\text { (cidades) }\end{array}$ & $\begin{array}{c}\text { Dimensões de pista } \\
\text { (metros) }\end{array}$ & $\begin{array}{c}\text { Terminal de pax } \\
\text { (unidade) }\end{array}$ & $\begin{array}{c}\text { Estacionamento } \\
\text { carros } \\
\text { (vagas) }\end{array}$ \\
\hline Araçatuba & $2.120 \times 35$ & 1.100 & 100 \\
\hline Bauru/Arealva & $2.100 \times 45$ & 2500 & 355 \\
\hline Marília & $1.700 \times 35$ & 395 & 120 \\
\hline Pres. Prudente & $2.100 \times 35$ & 1160 & 100 \\
\hline Ribeirão Preto & $2.100 \times 35$ & 1500 & 250 \\
\hline São José Rio Preto & $1.700 \times 35$ & 2000 & \\
\hline
\end{tabular}

Fonte: DAESP, 2008

Org.: Camilo Pereira, 2009

A importância do setor em âmbito federal e estadual confere a representatividade do transporte a partir dos relatórios da INFRAERO e do DAESP e, também, os dados aeroviários de composições infraestruturais dos aeroportos. De acordo com esses órgãos, os fixos e os fluxos aéreos do Estado têm justificado seu desenvolvimento econômico, reforçando seu papel de centro econômico do país.

Para a exiquibilidade do transporte aéreo, a destinação de investimentos em infraestrutura, a promoção ao crescimento, o planejamento/projetamento entre demais fatores, são fundamentais e o Estado tem por obrigatoriedade institucional realizar o projeto para a viabilização de um Plano Aeroviário Estadual (PAE) que funcione em conjunto com o Plano Aeroviário Nacional (PAN). Desde 1980, a Comissão de Estudos e Coordenação da Infraestrutura Aeroportuária (CECIA), posteriormente Instituto de Aviação Civil (IAC), vinha elaborando as revisões dos Planos Aeroviários Estaduais, uma vez que a Portaria $n^{\circ}$ 564/GM5, de 26 de abril de 1984, delegava essa competência ao Departamento de Aviação Civil (ANAC, 2008). 
De acordo com a ANAC, o Plano Aeroviário é um documento macrodiretor de planejamento integrado do transporte aéreo e da infraestrutura aeroviária e que é de interesse estadual, tendo por objetivo selecionar os aeroportos de interesse que estão aptos a receber recursos financeiros de programas federais e estaduais de investimentos. O PAE define, ainda, as diretrizes de desenvolvimento para os aeroportos selecionados, nos horizontes de curto, médio e longo prazos, bem como quantifica os custos relativos das obras e serviços necessários ao desenvolvimento dos aeroportos.

O Plano é elaborado em conformidade com as ações e normas emanadas pela Autoridade Aeronáutica e pelo Governo do Estado, para um horizonte de até vinte anos, período que por si só já é questionável, considerando que a teoria de perspectiva do PAE é totalmente incompatível na prática com as reais necessidades dos aeroportos e do transporte aéreo regional do Estado.

De acordo com a Decisão n ${ }^{\circ}$ 179, de 07 de maio de 2008, a ANAC aprovou a revisão do Plano Aeroviário Estadual de São Paulo (PAESP), que tem como meta vigorar pelo período de 2008 a 2027. Nesse sentido, o Plano tem como intuito possibilitar um melhor desenvolvimento da área aeroportuária do Estado em todos os seus aspectos, priorizando as vocações de cada região e permitindo ao Estado se programar em relação a investimentos futuros, apresentando demandas e características de desenvolvimento de aeroportos locais (SECRETARIA DOS TRANSPORTES, 2008).

O PAESP é um documento elaborado pelo DAESP a partir do mapeamento de todas as necessidades e características das regiões. Nesse sentido, o PAESP não é um plano definitivo, mas sim um "balizador de rotas e diretrizes" para o planejamento e desenvolvimento do setor. Contestavelmente, as entrevistas realizadas com os administradores dos aeroportos pesquisados mostraram que os administradores não possuem conhecimento do PAESP ${ }^{40}$. Notamos que o PAESP confere apenas como um documento, mas na prática não é operacionalizado pelos administradores dos aeroportos, o que demonstra a inadequação da teoria veiculada pelo DAESP com a prática exercida nos aeroportos. Nesse sentido, constatamos que o PAESP exige um esforço técnico na obtenção de dados, processos, ferramentas, conteúdo de pesquisas, pessoal especializado, recursos financeiros etc., para sua elaboração. Todavia, sua

\footnotetext{
${ }^{40}$ Com exceção do administrador do Aeroporto de Ribeirão Preto.
} 
execução é operada apenas no plano teórico, o que pode ser observado pelo tempo em que se excedeu o último PAESP.

A gestão e a política de desenvolvimento do setor aéreo, bem como a destinação de recursos para os aeroportos do Estado, contam ainda com o Programa Federal de Auxílio a Aeroportos (PROFAA), instituído pela Lei $\mathrm{n}^{\circ}$ 8.399, de 7 de janeiro de 1992.

Desta forma, o PROFAA tem como objetivo o melhoramento, reaparelhamento, a reforma e a expansão dos aeroportos de interesse estadual ou regional, podendo, portanto, os aeroportos do interior do Estado ser beneficiados com recursos do Programa. Os recursos do PROFAA correspondem a 20\% da arrecadação do Adicional de Tarifa Aeroportuária (ATAERO) que todo usuário do modal aéreo paga quando utiliza o transporte. No Estado de São Paulo, 12 aeroportos foram e são beneficiados pelo PROFAA: Araçatuba, Araraquara, Assis, Barretos, Bauru ${ }^{41}$, Bragança Paulista, Jundiaí, Lins, Marília, Presidente Prudente, Ribeirão Preto e São José do Rio Preto.

O PROFAA tem contribuído para a configuração e o melhoramento dos aeroportos do interior paulista, porém este fato não tem intensificado a importância da aviação comercial regional para o país, uma vez que os aeroportos, após serem beneficiados com os recursos, continuam a abastecer um mercado de baixa densidade de fluxos de passageiros e de voos, como nos casos dos aeroportos de Araçatuba e Marília, em razão da ausência de um planejamento prévio que potencialize o aeroporto e que estimule o interesse da demanda e das empresas em operar nesses fixos.

\subsection{A questão infraestrutural dos complexos aeroviários no Estado de São Paulo: a necessidade de investimentos}

Diante de um novo contexto de integração territorial, no qual a circulação torna-se cada vez mais veloz, num processo acelerado pelo período técnico-científicoinformacional (SANTOS, 2002), o setor de transporte aéreo tem contribuído para as grandes mudanças nas formas de mobilidade territorial. Ao precisar essas

\footnotetext{
${ }^{41}$ Durante as entrevistas realizadas nos aeroportos regionais do interior paulista, constatamos que os recursos do PROFAA têm sido constantemente investidos em aeroportos paulistas. No dia 17 de outubro de 2008, em entrevista realizada no Aeroporto de Bauru/Arealva com a administradora do Aeroporto, Sra. Ana Lucia Zuiane Ribeiro, obtivemos a informação de que o Aeroporto Estadual de Bauru/Arealva, o mais novo aeroporto público do Estado de São Paulo, contou com verbas do Governo do Estado (R\$ 30 milhões) e do PROFAA (R\$ 20 milhões).
} 
transformações que integraram o território e que causaram impactos socioespaciais, consideram-se cruciais para o entendimento da composição técnica do Estado as mudanças advindas com a instalação dos complexos aeroviários no interior do Estado de São Paulo.

Compreende-se que a instalação de uma infraestrutura nos moldes de um aeroporto, trouxe, pari passu, uma reordenação do espaço urbano, que a priori quantifica e qualifica determinados territórios. Observa-se, ainda, que as cidades que possuem aeroportos públicos consubstanciam-se como cidades dinâmicas, do ponto de vista econômico, e como centros urbanos especializados e estrategicamente interligados à rede urbana do Estado.

Essas cidades constituem elos entre os setores de produtividade e consumo, por representarem nós da rede urbana paulista, além de definirem a desconcentração urbano-industrial no Estado de São Paulo. Nesse sentido, estas cidades, ao serem configuradas como centros polarizadores, demandam infraestruturas para 0 desenvolvimento dos transportes, sobretudo do setor aéreo, como meio de interação espacial e desenvolvimento econômico regional.

Nessa perspectiva, compreende-se que a influência exercida pelas cidades em seu entorno reforça sua importância em âmbito regional, intensificando as interações espaciais e favorecendo a demanda pelo modal aéreo. As cidades analisadas neste trabalho confirmam sua dinâmica regional complementadas pela sua infraestrutura aeroviária.

O imperativo da sociedade atual, influenciado pelo meio técnico-científicoinformacional, exige uma fluidez territorial que remonta a uma perspectiva intensamente renovadora, ou seja, a fluidez demanda o aperfeiçoamento de novas técnicas, de novos sistemas de objetos para que se intensifiquem os sistemas de ações (SANTOS, 2002).

A mobilidade do capital se dá em decorrência da acumulação de infraestrutura e da disponibilização de serviços. Limonad (2002) assegura que os investimentos e a dependência de infraestruturas interferem na mobilidade do capital. Assim, considera-se que o capital tem a facilidade de integrar-se e desintegrar-se na medida em que os fixos promovem ou não sua estabilidade baseada na quantidade e na qualidade da base material no local onde o capital se desenvolve. Para Bordo (2005), a 
infraestrutura de transporte adequada e de qualidade propicia condições mais favoráveis para a dinâmica econômica dos centros urbanos.

Os investimentos em infraestrutura possuem uma conotação técnica, de operação, regulamentação, prestação de serviço, como base material no território para promoção da fluidez. A intensificação de tais tipos de investimentos possibilita a organização dos arranjos competitivos do setor, influenciando a caracterização das formas e estratégias das companhias aéreas no mercado regional, nacional e internacional definindo o uso do território e, também, o uso do transporte pelos agentes sintagmáticos (RAFFESTIN, 1993), como, por exemplo, os usuários e as empresas fornecedoras do serviço aéreo.

A noção de cidade aeroviária expressa a dimensão físico-territorial dos grandes aeroportos, pois estes necessitam de ampliações para atender ao intenso fluxo de pessoas que demandam seus serviços, ao recebimento de elevada quantidade de grandes aeronaves e à movimentação de significativos volumes de mercadorias transportadas. Esse processo de reestruturação técnica implica fixos integrados junto ao meio urbano (CAPPA, 2007).

Nesse contexto de análise, a questão infraestrutural do Estado de São Paulo, isto é, os investimentos em infraestrutura, articulam e integram os territórios descontínuos, uma vez que também são organizados na intenção de incluir estes territórios na dinâmica da produção do espaço urbano. Baseados nessa assertiva, a ANAC alega que os trabalhos relativos à base material aeroviária são coordenados pelo órgão e pelos departamentos especializados

Compreende-se, portanto, a inerência dos investimentos em infraestrutura aeroviária que são imprescindíveis para o desenvolvimento e crescimento do setor aéreo brasileiro, considerando sua estrutura econômica e de comprometimento com o usuário do modal, tanto para os passageiros como para o ramo de cargas. Desta forma, a circulação aérea está interligada aos serviços empreendidos pelas companhias aéreas e aos investimentos em infraestrutura que são angariados pelos setores públicos do Governo e pelos órgãos especializados.

A nova tendência do aeroporto, atualmente, consiste na reestruturação de sua funcionalidade, não mais como local de embarque e desembarque de passageiros e cargas, ou seja, ponto de transbordo, e sim como um centro de serviços para os usuários 
do transporte aéreo. Esta tendência tem favorecido constantes reformas, manutenções e, principalmente, os investimentos em infraestrutura. Ainda que sejam investimentos insuficientes, o direcionamento das somas de verbas totais em estruturação aeroviária no Estado de São Paulo computa entre os anos de 1995 a 2008 o montante de R\$ 182.030.823,91, conforme (Tabela 10) distribuição entre as cidades beneficiadas.

Tabela 10 - Investimentos do Governo do Estado de São Paulo em infraestrutura aeroviária (Em reais e porcentagem) - 1995 a 2007

\begin{tabular}{c|c|c}
\hline Cidades & Valores & Percentual \\
\hline Araçatuba & $1.963 .577,44$ & 1,1 \\
\hline Bauru/Arealva & $53.681 .719,67$ & 29,5 \\
\hline Marília & $1.637 .581,64$ & 0,9 \\
\hline Presidente Prudente & $87.918,20$ & 0,04 \\
\hline Ribeirão Preto & $40.822 .613,37$ & 22,4 \\
\hline São José do Rio Preto & $17.978 .865,96$ & 9,9 \\
\hline Total no Estado & \multicolumn{2}{|c}{$182.030 .623,91$} \\
\hline
\end{tabular}

Fonte: DAESP, 2009

Org.: Camilo Pereira, 2009

Os aeroportos são, em primeiro lugar, os locais de funcionamento das companhias aéreas em suas diversas especialidades: transporte regular de passageiros, charter, táxi-aéreo etc., por meio de linhas internacionais, nacionais e regionais, transporte de carga desdobrada em frete, correio e entrega expressa. As operações destas companhias dependem de uma série de serviços fornecidos no solo: hangaragem, abastecimento de combustível, manutenção, catering, manuseio de bagagens, telecomunicações, apoio à navegação, entre outros. Além disso, a atividade aeroviária envolve uma significativa variedade de serviços públicos e privados de regulação ou apoio ao deslocamento de mercadorias e pessoas. Entre estes estão, de um lado: polícia e segurança, alfândega e receita, justiça e a própria administração aeroportuária; de outro lado, serviços privados como, por exemplo, bancos e câmbio, varejo, restaurantes, lanchonetes e locação de veículos (ALMEIDA, 2004).

A implantação de novas formas organizacionais e de novas tecnologias produtivas, tais como os investimentos infraestruturais, que promovem o desenvolvimento e a interconexão territorial, revelam a consonância entre $o$ planejamento, a gestão e a operacionalidade dos órgãos responsáveis.

Desta forma, o crescimento do tráfego aéreo nos aeroportos brasileiros vem exigindo a adequação e mais investimentos em estruturação do efetivo de operadores, 
uma postura mais pró-ativa e melhoria no processo de tomada de decisão visando à garantia da manutenção dos níveis de operacionalidade e segurança, considerando que o transporte aéreo é o único modal capaz de garantir uma velocidade de mobilidade das pessoas e de cargas, caracterizando a supressão espacial na relação temporal.

Em $2006^{42}$, foram investidos $\mathrm{R} \$ 889,7$ milhões em obras e equipamentos e ainda aplicados $\mathrm{R} \$ 96,1$ milhões em obras com recursos do saldo do aporte de capital realizado pelo Governo Federal em 2005. Com o intuito de garantir a operacionalidade e a segurança compatível com as necessidades do país, os investimentos foram direcionados aos aeroportos com capacidade de tráfego, carga e passageiros saturados e aos de interesse estratégico do Governo Federal. Contudo, a aviação regional fica relegada a uma reduzida parcela dos investimentos destinados aos aeroportos, impossibilitando a otimização do segmento.

No entanto, as atuais necessidades de expansão de infraestrutura aeroportuária, para que a crise hoje vivenciada não se perpetue e bloqueie o crescimento econômico, são muito superiores aos previstos no plano de investimentos dos órgãos competentes (SALGADO, 2009).

De acordo com os resultados obtidos a partir dos dados das entrevistas realizadas nos aeroportos pesquisados, compreende-se que os investimentos em infraestrutura têm sido destinados à melhoria e adequação da capacidade operacional dos aeroportos. Assim, os administradores dos aeroportos trabalham de acordo com a destinação de recursos do Governo do Estado; todavia, esses recursos não são suficientes para garantir a qualidade e quantidade de estrutura necessária.

As entrevistas demonstraram que há uma insatisfação por parte da estrutura administrativa dos aeroportos do interior quanto à administração do órgão de competência da aviação comercial do Estado. No entanto, cabe destacar, que os administradores dos aeroportos são funcionários do próprio DAESP e que, logo, as informações obtidas confirmam em alguns casos uma "visão" estereotipada das ações do DAESP, enquanto órgão destinador de verbas.

É possível observar que a condição infraestrutural dos aeroportos apresentase em qualidades insuficientes para o transporte aéreo. As figuras a seguir elucidam as condições de infraestrutura interna dos aeroportos, como o terminal de passageiros,

\footnotetext{
${ }^{42}$ Dados referentes ao último relatório da INFRAERO, ano de 2006.
} 
demonstrando a necessidade de melhoria em alguns sistemas aeroviários, como, por exemplo, os Aeroportos de Marília, Presidente Prudente e Ribeirão Preto, que não suportam mais a quantidade de passageiros que embarcam e desembarcam nos terminais.

Foto 3 - Área interna do Aeroporto de Araçatuba - 2008

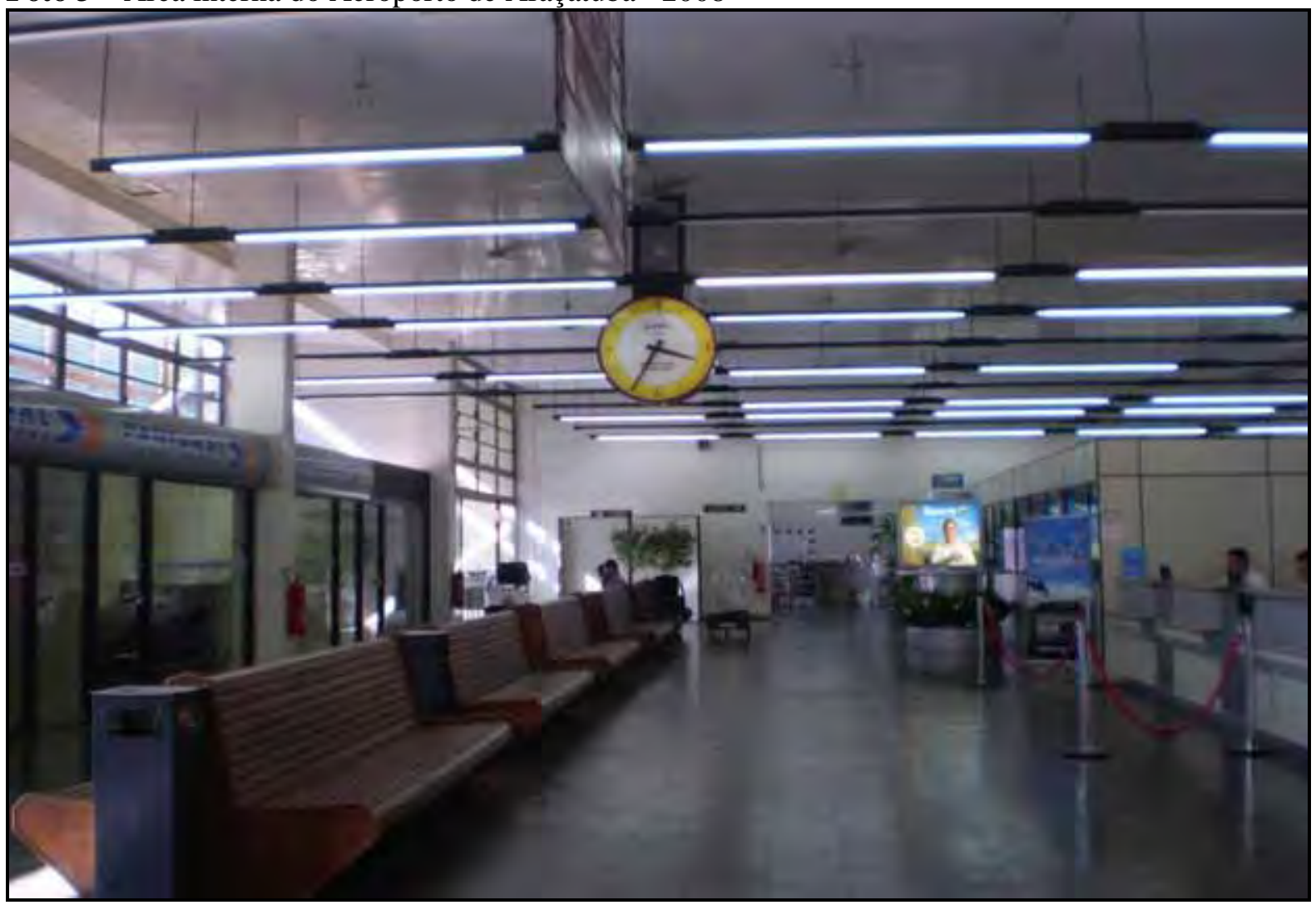

Fonte: Camilo Pereira, 2008. 
Foto 4 - Área interna do Aeroporto de Bauru/Arealva - 2008

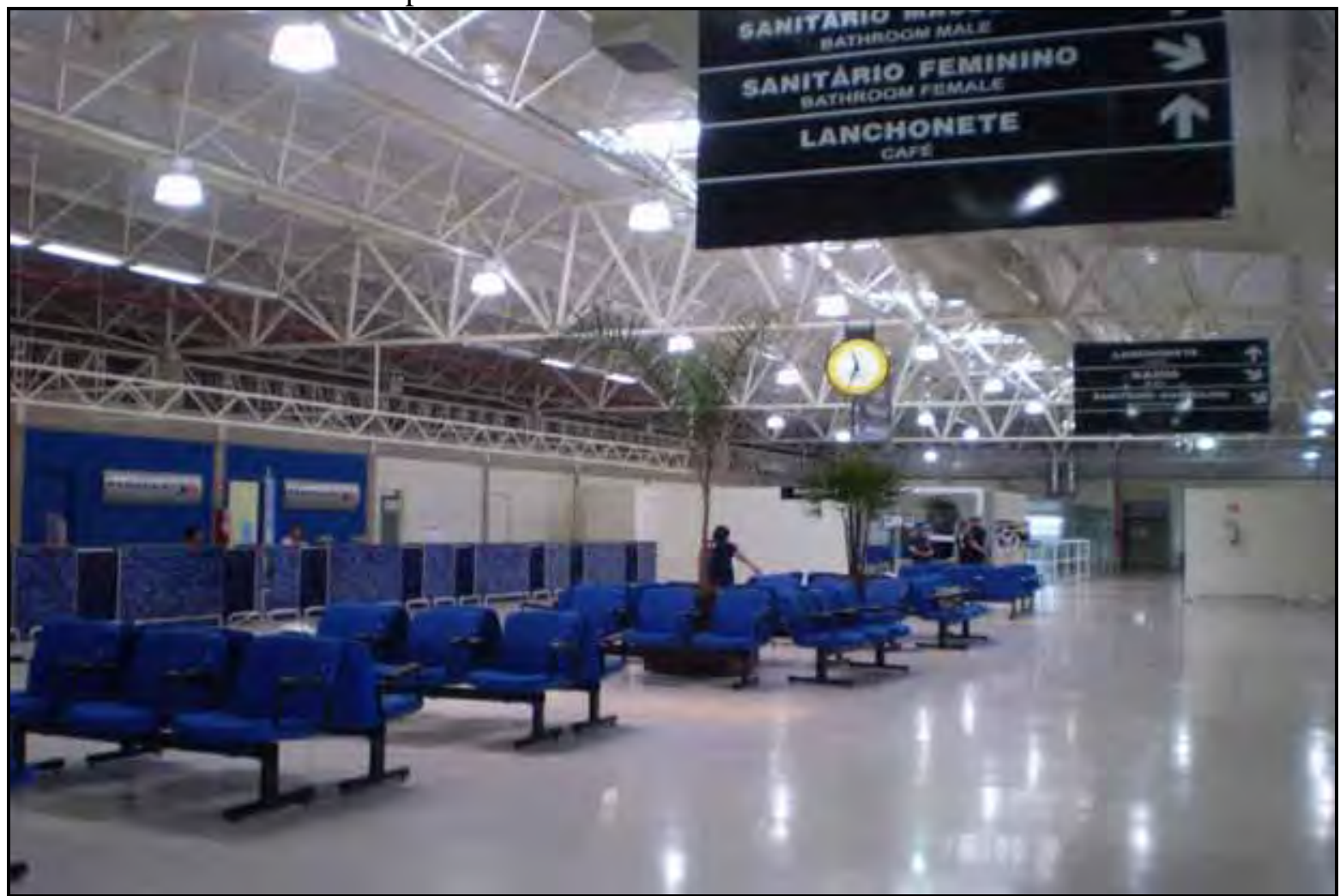

Fonte: Camilo Pereira, 2008.

Foto 5 - Área interna do Aeroporto de Marília - 2008

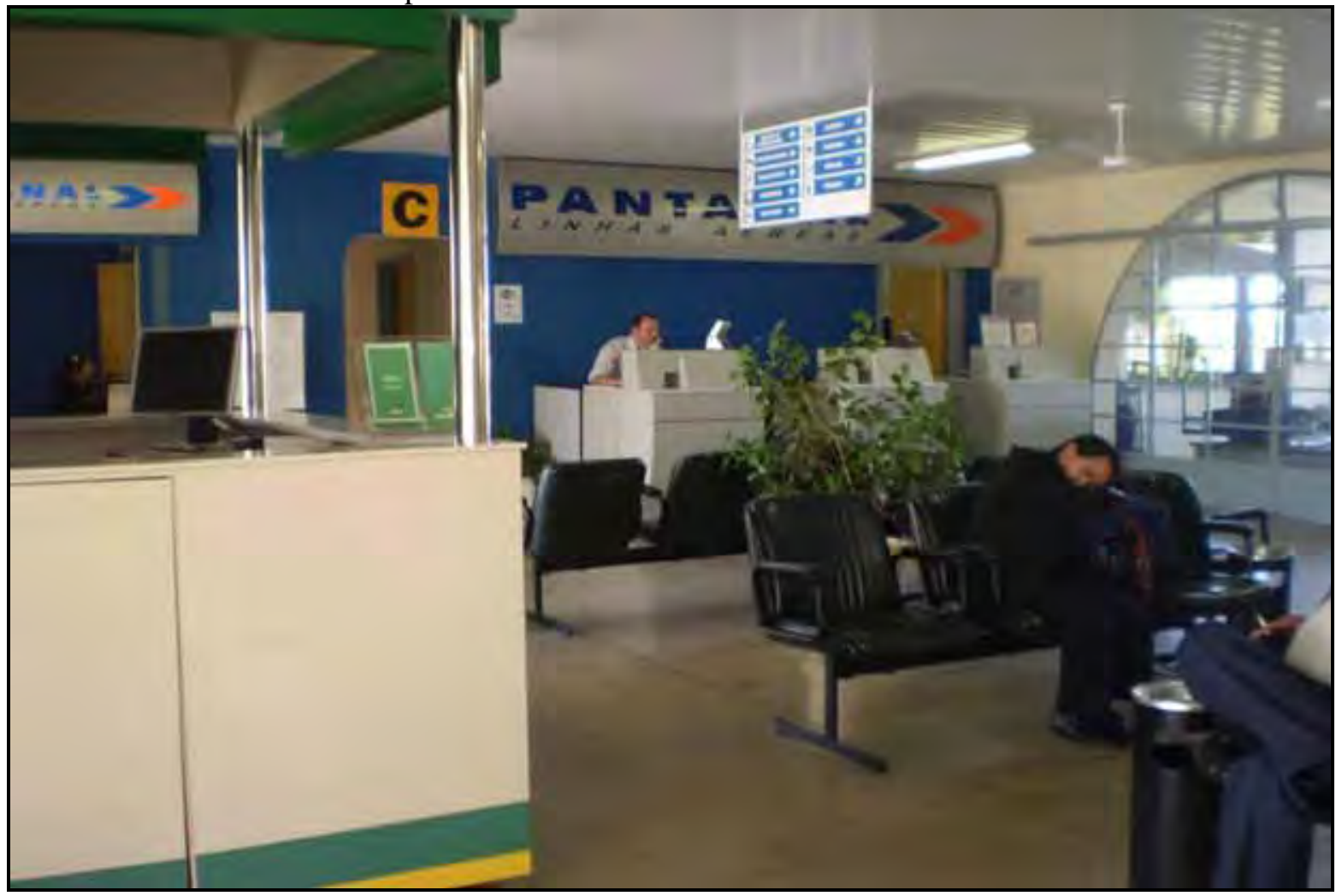

Fonte: Camilo Pereira, 2008. 
Foto 6 - Área interna do Aeroporto de Presidente Prudente -2008

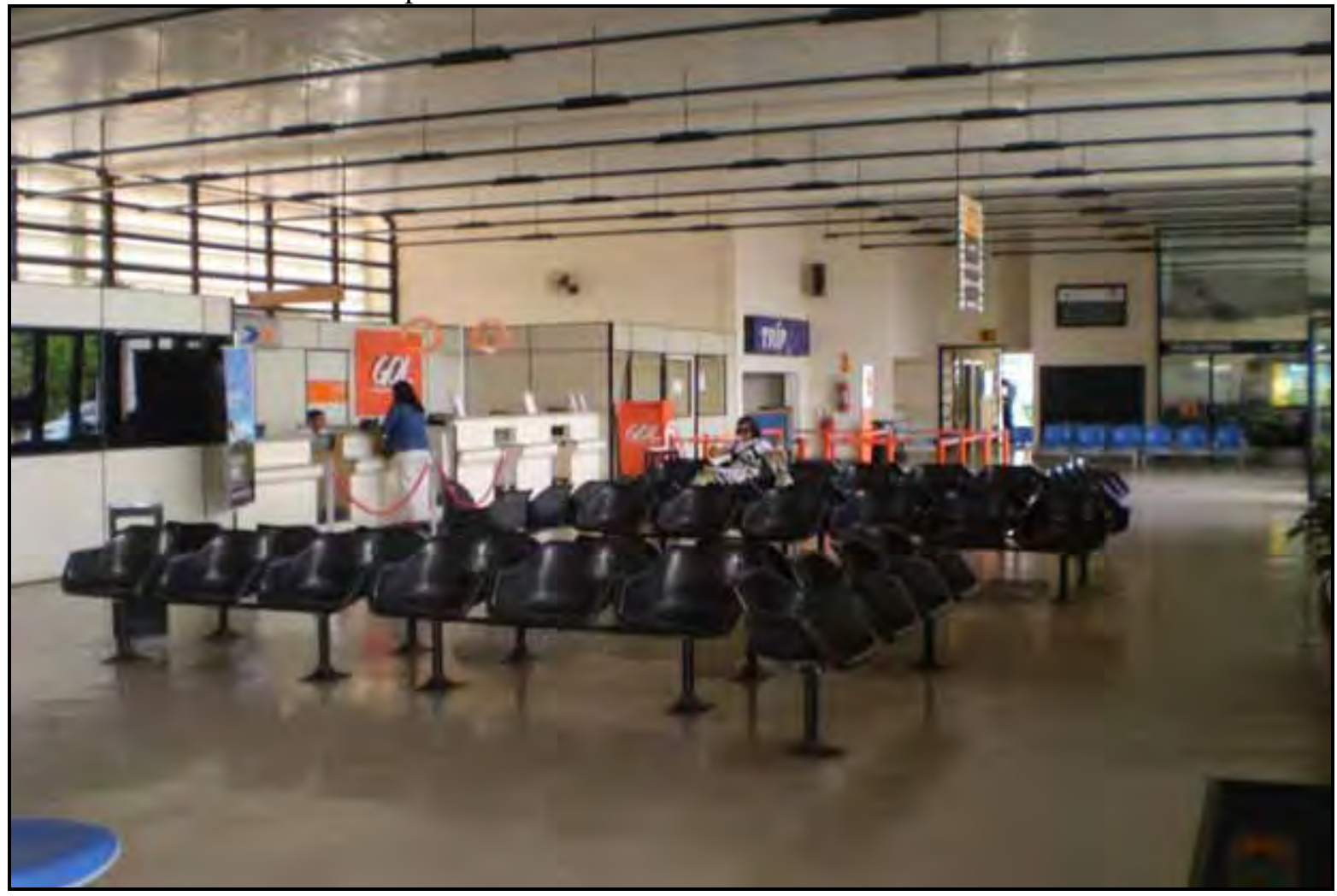

Fonte: Camilo Pereira, 2008.

Foto 7 - Área interna do Aeroporto de Ribeirão Preto -2008

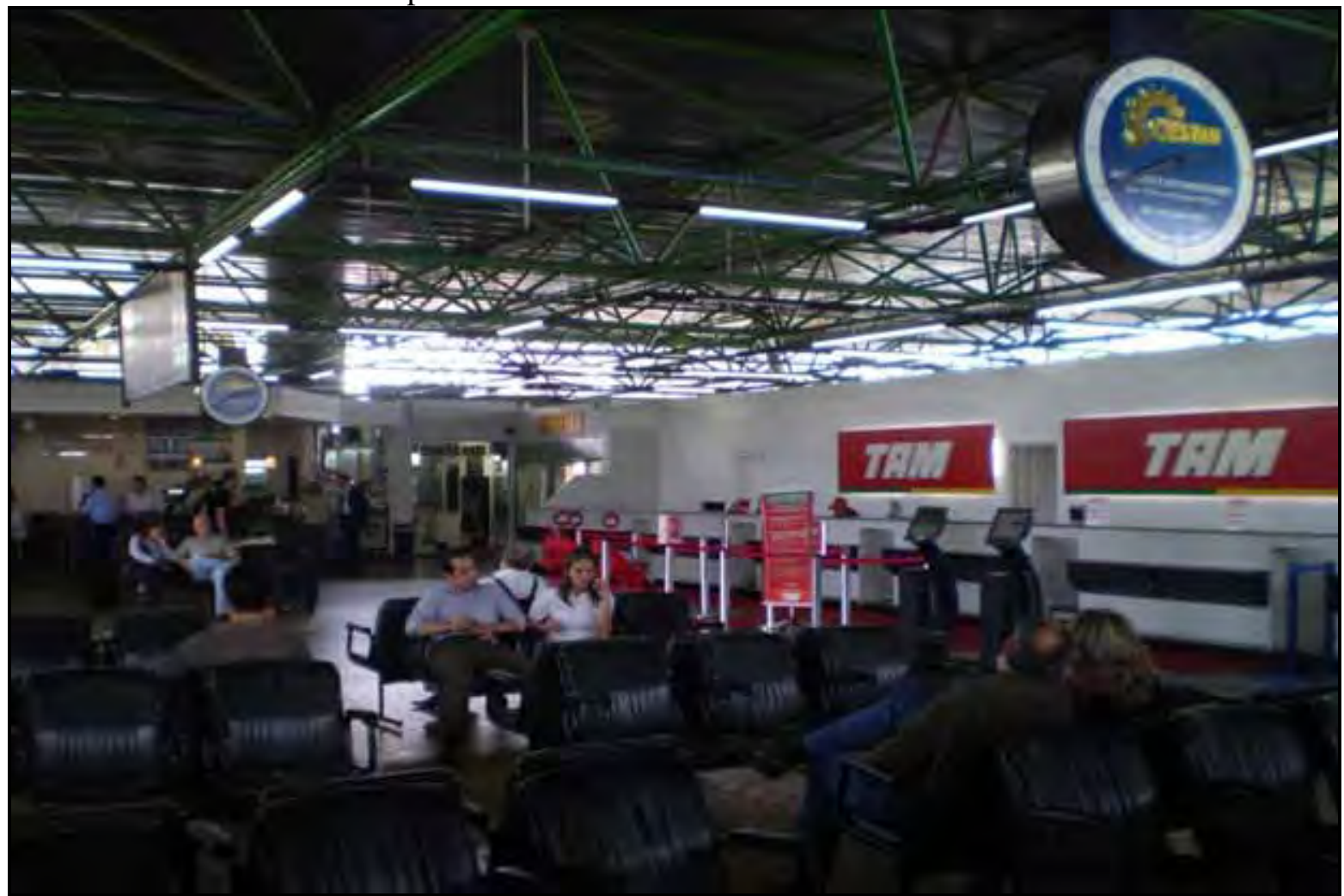

Fonte: Camilo Pereira, 2008. 
Foto 8 - Área interna do Aeroporto de São José do Rio Preto -2008

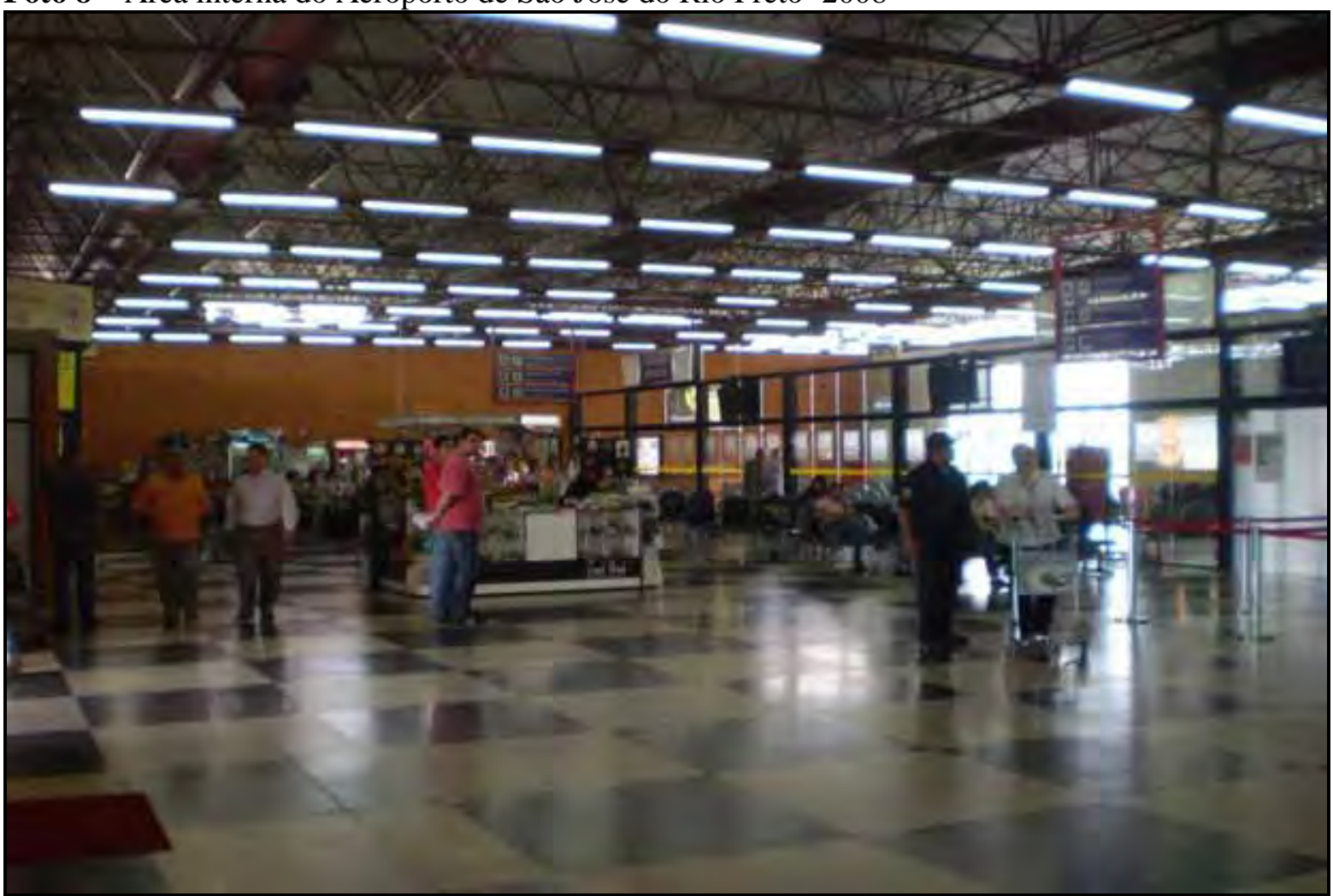

Fonte: Camilo Pereira, 2008.

Desta forma, procuramos demonstrar, elucidativamente, que as condições gerais de infraestrutura apresentada pelos aeroportos compreendem diferenciações de acordo com a movimentação aérea que os aeroportos possuem. Observa-se que os aeroportos que possuem terminais de passageiros e salas de embarque e desembarque com capacidade considerável são os aeroportos de Bauru/Arealva, que foi inaugurado no ano de 2006 e que, por isso, possui uma condição de infraestrutura mais compatível que os demais aeroportos do Estado, pois obrigatoriamente teve de se adequar às novas condições estruturais exigidas pela ANAC.

O Aeroporto de Presidente Prudente passa recentemente por uma obra para a reforma e a ampliação das salas de embarque, desembarque, pista, entre outras adequações, que contribuirá para a adequação das condições de infraestrutura do aeroporto. Nos últimos três anos, a movimentação de passageiros aumentou em $300 \%$ (DAESP, 2009), tornando o aeroporto incapaz de sustentar o montante de passageiros que utilizam o terminal.

Segundo informações obtidas junto ao Aeroporto de Araçatuba, o sítio aeroportuário da cidade apresenta boas condições, embora necessite de melhorias, que 
atualmente estão sendo realizadas. A demora na melhoria da infraestrutura do aeroporto acelerou a saída de duas empresas aéreas regionais que operavam voos a partir de Araçatuba. O resultado desse déficit de empresas gerou uma diminuição do número de passageiros que embarcavam no aeroporto.

No tocante às condições infraestruturais do Aeroporto de Marília, notamos que o pequeno terminal de passageiros e as salas de embarque não condizem com as características dos aeroportos do Estado, uma vez que o local apresenta condições totalmente precárias para o bom funcionamento do transporte aéreo. Nota-se que a atuação do terminal tem apresentado percentual pouco lucrativo, de modo que apenas uma empresa opera no aeroporto.

A partir dos dados estatísticos de movimentação aérea, das entrevistas e das visitas realizadas nos aeroportos, notamos que as condições são precárias, mesmo nos principais aeroportos regionais, como nos de Ribeirão Preto e São José do Rio Preto. As entrevistas revelaram que há necessidade de investimentos e que estes só podem ser feitos de acordo com a disponibilização de recursos do Estado.

Estas considerações nos levaram às indagações sobre o atual projeto do Governo Federal concernentes às concessões dos aeroportos. Desse modo, observamos que a proposta tem apoio de alguns administradores. No entanto, as críticas conferem a estrutura deficitária que os aeroportos do interior apresentam o que, segundo os administradores, inviabiliza a proposta de concessões do Governo para o segmento regional.

\subsection{A proposta de concessões dos aeroportos brasileiros e a necessidade de um marco regulatório}

A questão relacionada às concessões dos aeroportos ao setor privado tem sido muito discutida na aviação comercial, em razão de alguns fatores correlatos ao desenvolvimento do transporte aéreo, como por exemplo, a crise que se instala no setor, a intensa necessidade de investimentos e, também devido ao fato de o transporte aéreo compreender um setor de constante valor de manutenção, investimentos e adequação tecnológica.

No tocante a isso, constata-se, mediante as atuais discussões sobre as concessões aeroportuárias, que esse processo está intrinsecamente relacionado aos 
estudos sobre a complexidade das articulações entre o setor público e a iniciativa privada, que se refere, indubitavelmente, a um conjunto de elementos que devem tratar, principalmente da formação de um Estado regulador ${ }^{43}$.

Antes da apresentação desse projeto de concessão e de nossas abordagens sobre o mesmo, destacamos que embora a atual discussão desta concessão não se circunscreva nos fixos analisados nessa pesquisa, ou seja, nos aeroportos supracitados, é de essencial importância que tratemos desta discussão; primeiro porque se trata de um projeto que tem o objetivo de estender-se para os aeroportos regionais, sobretudo do Estado de São Paulo - que caracteristicamente são os mais movimentados do país -; segundo porque o modelo de concessão proposto para os aeroportos comportam sinuosidades que merecem um maior detalhamento.

Dentro dessa lógica, apresentamos sucintamente o modelo de concessão, ainda em elaboração, e as prerrogativas consideradas por nós, no desenvolvimento desse projeto. Contudo, não é nosso objetivo discorrer sobre os modelos de concessão e discuti-los pormenorizadamente, mas sim inserir uma proposta de concessão baseada nos ideais de Ignácio Rangel (2005).

A incumbência de elaborar o projeto de concessão de aeroportos brasileiros é da ANAC, que juntamente com o BNDES desenvolve, atualmente, uma proposta de concessão aeroportuária, defendida pelo Ministro da Defesa, Nelson Jobim. Este projeto tramita entre os órgãos públicos e está previsto para vigorar a partir de 2010. O modelo previamente será adotado no Aeroporto Internacional Tom Jobim/Galeão, no Rio de Janeiro, no Aeroporto de Viracopos, em Campinas, e em um aeroporto que, provavelmente, será construído em São Paulo. Há três possibilidades de outorga, das quais a ANAC define como:

1. Sistema nacional: concessão de todos os aeroportos como uma estrutura única, com administração centralizada;

2. Aeroportos individuais: concessão de cada aeroporto separadamente;

\footnotetext{
${ }^{43}$ Destacamos que a referência ao Estado regulador parte de uma análise que trata o mesmo como um agente planejador de políticas e programas capazes que incrementar o desenvolvimento econômico do país, bem como o consideramos como um agente financiador, ainda que em articulação com o setor privado.
} 
3. Grupos de aeroportos: concessão de aeroportos em grupos, formados de acordo com aspectos econômicos. Identificando-se os "aeroportos âncora" (mais rentáveis), que serão concedidos junto com outros menos rentáveis ou deficitários.

De acordo com a ANAC esse projeto não corresponde aos modelos de privatização adotados na década de 1990. A agência o define como um projeto de transferência do setor para a exploração da iniciativa privada, aproximando-se do que o Governo chama de Parceria Público-Privada (PPP).

Ao considerar a vinculação do setor público com o setor privado, Rangel (2005) assevera que as atividades que são transferidas do setor público para o privado "não" implicam em retirar sua obrigatoriedade e, ao mesmo tempo, a propriedade do Estado em relação aquela atividade. Em outras palavras, o modelo preconizado por Rangel (2005) não corresponde a venda de ativos tangíveis públicos à iniciativa privada. O que há é uma unidade dialética entre o setor público e o privado, sem que necessariamente um tenha o poder do outro.

A proposta de Rangel (2005) sobre a concessão de serviços de utilidade pública à iniciativa privada refere-se a um modelo no qual o Estado (poder concedente) delega ao concessionário o poder de exploração, mediante os investimentos e a manutenção daquele serviço concedido, ficando a cargo do Estado a retirada do direito do concessionário no caso de não adequação as normas estabelecidas no contrato. Em outras palavras, Rangel (2005) sistematiza sua idéia alegando que:

A conversão da concessão do serviço público à empresa privada, parece-me suficiente para colocar à frente do dito serviço um concessionário solvente. Com isso, o Estado não mais estará desmoralizado, coberto pela promessa de recursos fiscais futuros, terá um aval hipotecariamente garantido, porque o Estado passará a assumir a dupla função de poder concedente e credor hipotecário, em vez de sua presente posição de devedor insolvente [...]. Em caso de inadimplência do novo concessionário privado, o Estado, como poder concedente, poderá tomar-lhe a concessão e, como credor hipotecário, tomar-lhes os bens, oferecendo a concessão e as competentes instalações a outro concessionário, mais capaz (RANGEL, 2005, p. 719).

Para que isso ocorra, o autor salienta que a articulação entre o setor público e a iniciativa privada demanda, sobretudo, a atuação do Estado, como agente regulador e executor. Baseados nessa lógica as definições de Rangel (2005) tratam a relação público-privado mediante o papel desempenhado pelo Estado enquanto planejador 
desenvolvimentista e, ao mesmo tempo, fiscalizador daquilo que concede, para que seu planejamento, quando em execução, não se aliene enquanto o que é dever do Estado e o que é obrigação do concessionário.

Explicada a proposta de Rangel (2005) compreendemos que no atual estágio em que se encontra o setor aéreo brasileiro, inclusive o paulista, a proposta rangeliana de concessão dos aeroportos é uma alternativa mais indicada, devido ao modelo em que se subscreve esse tipo de parceria, no qual o poder concedente continua vinculado ao empreendimento, ficando a cargo do concessionário a exploração e os retornos passíveis à sociedade. Com isso, o Estado cumpriria uma dupla função, ou seja, a de interventor e planejador, garantindo com isso sua função de agente regulador, planejador, poder concedente e fiscalizador do serviço concedido, realizando com isso, também, a função de poder concedente e credor hipotecário, consequentemente estaria promovendo a competência da infraestrutura aeroportuária.

Entretanto, de acordo com o próprio autor é necessário o planejamento ou o projetamento que constitui a "mecânica do desenvolvimento econômico", ou seja, é preciso colocar em prática o movimento dialético entre superação da crise e o crescimento econômico.

Rangel (2005, p.718) assevera que "a economia está em crise porque o Estado, atual responsável pelas atividades a expandir, não se encontra em condições de mobilizar os excedentes que o setor privado é capaz de produzir". Nessa mesma análise, Silveira (2006), considera que os modelos de concessões e privatizações brasileiros têm ocorrido de forma indiscriminada, o que o autor chama de "entrega do patrimônio público". Esse processo tem acontecido por conta da ausência de um Estado ativo e planejador. Defende-se, portanto, um projeto de concessões baseados nos instrumentais definidos por Ignácio Rangel (2005), o qual prevê que o modelo de concessões esteja atrelado a uma política macroeconômica desenvolvimentista, que favoreça um efeito multiplicador nos diversos setores da economia, mas que tenha como instrumento o planejamento e como instrumentador o Estado.

O transporte aéreo é um ramo de serviço altamente dependente de investimentos que podem ser realizados pela iniciativa privada. Todavia é necessário destacar que não se trata de "entregar" o setor aéreo à livre ação da iniciativa privada, e muito menos ao mercado, mas "integrar" a demanda (uma vez que há capacidade de 
geração de tráfego no Brasil que viabiliza o crescimento do setor) e a oferta (já que o setor privado tem interesse em investir e explorar o transporte aéreo e este, por sua vez, necessita de investimentos).

Contudo, é necessário atentar para o funcionamento dessa concessão, ou seja, é preciso considerar sua aplicabilidade. A legislação deve conduzir à fixação correta e transparente dos parâmetros estratégicos quando se concede um serviço de utilidade pública, para que não se desvincule o custo do serviço e tarifa a viger. Esse modelo deverá abrir a porta para a solução desse problema, primeiro como forma de substituir a visão ideológica da privatização, ou seja, da venda irresponsável de ativos e; segundo, como uma maneira de se superar a presente crise do setor (RANGEL, 2005).

O Brasil possui a segunda maior rede de aeroportos em nível mundial (ANAC, 2008) e esse potencial necessita de políticas que promovam a capacidade aeroviária do país. O transporte aéreo estabelece-se como modal intrínseco ao sistema de transportes e ao desenvolvimento regional. A necessidade de administrar o espaço faz com que o transporte aéreo configure espacialmente a lógica da organização territorial e permite também emergir eixos de ligação aérea viabilizados pela sua capacidade de redução de tempo de deslocamento no espaço. Assim, temos que o país e, sobretudo, o Estado de São Paulo possuem um potencial aeroportuário que necessita de investimentos e as ações conjuntas entre o setor público e o setor privado, que podem, inclusive, convergir positivamente para o desenvolvimento econômico nacional. Para tanto, é preciso planejamento, execução e fiscalização.

Todavia, o planejamento e a gestão necessitam prioritariamente de um marco regulatório capaz de acelerar o potencial que o setor aéreo apresenta, mas tendo como vetor principal a regulamentação do setor. Salgado e Motta (2005) asseveram que, com o surgimento da ANAC, criou-se a expectativa de que, a partir da instituição dessa nova entidade, a regulação do setor viria a adotar premissas modernas, com o estímulo à competição, sem descuido de sua função regulatória. Entretanto, a regulamentação observada na atuação da ANAC não tem conferido um estímulo ao desenvolvimento do modal aéreo; pelo contrário, as dificuldades na administração da agência têm fragmentado o setor de transporte aéreo, que se agrava com a não intervenção do Estado. Todavia, destacamos que a problemática do setor aéreo não se baseia 
exclusivamente na ação da ANAC, há uma mobilidade de execução por parte das empresas aéreas que também agrava a crise aérea atual.

Constata-se que a criação de entidades administrativas que gestionam a operação dos setores de infraestrutura no Brasil, vem exigindo a instauração de novos marcos regulatórios que possam garantir os investimentos necessários, promover o bemestar dos consumidores e usuários e aumentar a eficiência econômica e não deixar o setor a atuação predatória do mercado. Desta forma, Salgado (2009) assevera que a debilidade do transporte aéreo manifesta-se historicamente mediante as falhas do Governo que não podem ser substituídas pelas falhas do mercado. A autora elenca diversos fatores que tem desestimulado o desenvolvimento do setor, como:

[...] vácuo regulatório, ausência de coordenação de ações e estratégias por parte das diferentes autoridades no setor, falta de clareza quanto às competências, ausência de investimentos em infraestrutura, contingenciamento de recursos destinados à manutenção e à modernização de equipamentos responsáveis pela segurança do tráfego aéreo, conivência entre regime de mercado para o transporte e o modelo centralizado e estatizado de operação e gerência de aeroportos (SALGADO, 2009, p. 7).

Concluímos que permanece imprescindível a definição de um marco regulatório para o setor de transporte aéreo, que identifique os gargalos estruturais e reconheça corretamente as falhas existentes, obscurecidas pela atuação das entidades reguladoras, mas que ao mesmo tempo, não permita que estas falhas sejam ampliadas em razão de um mercado que age e reage a sua própria dinâmica. Assim, de acordo com Rangel (2005), faz-se mister que o papel do Estado seja, antes de tudo, um condicionador de desenvolvimento da economia brasileira e, nesse aspecto, a presença da iniciativa privada pode contribuir para acelerar o crescimento econômico do setor, assim como favorecer a integração territorial do país, mediante o transporte aéreo.

\subsection{Considerações finais ao capítulo II}

Neste capítulo, realizou-se uma análise acerca do transporte aéreo regional no Estado de São Paulo. Para tanto, consideramos a dinamicidade do modal a partir das inovações tecnológicas e mediante a processualidade temporal, registrando, assim, as interpretações de Santos (2003) e Silveira (2009).

Nessa perspectiva, tratamos o "circuito espacial da circulação" como um conceito concernente à mobilidade territorial, como fator intrínseco ao sistema de 
transporte, sobretudo o aéreo, tendo-o como vetor de acessibilidade e referência para a modernização e inovação dos sistemas de objetos, como por exemplo, os fixos e, para os sistemas de ações, tais como os fluxos.

As inovações tecnológicas configuram, numa lógica capitalista, o espaço de produção e também de consumo, ou seja, ao projetarem dinamismo ao processo produtivo, favorecem a fluidez territorial que, nesse sentido, motiva as interações econômicas, sociais e espaciais, contribuindo para a integração territorial e também para o consumo nos e dos territórios.

Dentro dessa lógica, apresentamos a caracterização do desenvolvimento do setor de transporte aéreo no Estado de São Paulo, referenciando os principais fatores que nortearam o setor, tais como a construção dos principais aeroportos, como o Aeroporto de Congonhas, Cumbica/Guarulhos e Viracopos, bem como a criação da principal empresa aérea paulista, a VASP. Assim, configurou-se uma análise evolutiva dos fatos, temporalmente assinalados e que fomentaram a necessidade de dinamizar o setor aéreo no segmento regional.

O desenvolvimento do setor aéreo regional está atrelado ao processo de desconcentração urbano-industrial, iniciado no Estado de São Paulo a partir década de 1970. Nesse sentido, as indústrias desconcentraram suas atividades produtivas para o interior e centralizaram a gestão na capital paulista. Esse fato possibilitou os rumos para o desenvolvimento e crescimento do setor aéreo regional, uma vez que aumentou a demanda pelo modal em direção ao interior e do interior para a capital, emergindo eixos de ligação já viabilizados pelo transporte rodoviário.

Ao tecermos abordagens sobre a gestão e as políticas de desenvolvimento do setor aéreo regional no Estado de São Paulo, temos que o órgão de fomento estadual, o DAESP, tem restringido sua atuação, sobretudo na operacionalização de captação de investimentos em infraestrutura, o que tem implicado em prejuízos para os aeroportos do interior do Estado, considerando que estes carecem de investimentos que corresponda a crescente demanda e, para que, também, contribuam para a dinamização do setor aéreo nas cidades destacadas, na tentativa de atrair empresas para a operação de linhas aéreas no Estado.

Faz-se urgente a ação do Governo, no sentido de efetivar os investimentos imprescindíveis ao tráfego aéreo regional. Não se trata de optar por setores prioritários, 
mas sim de regular e instruir um planejamento competente e uma infraestrutura, no mínimo, adequada. Oliveira (2009) alega que mesmo não sendo possível garantir a universalização completa do setor, há formas de se planejar e alcançar importantes resultados positivos para importantes indicadores de cobertura espacial, tal como a participação dos aeroportos regionais no "bolo" do tráfego aéreo brasileiro.

Enfatizamos, contudo, que a necessidade de investimentos para o desenvolvimento e eficácia do transporte aéreo, não induzem uma relação de causa e consequência, o que destacamos aqui é que os investimentos e a sua aplicabilidade são fatores que cooperam para o crescimento do setor.

As estratégias de Governo convergem para a concessão da exploração dos aeroportos brasileiros à iniciativa privada. Mediante isso, tramitam projetos de concessão de aeroportos, a partir das parcerias público-privadas. Esse projeto é uma proposta de investimentos em infraestrutura, todavia a necessidade de uma postura política condizente é crucial para que esse projeto não repercuta no que Lamoso (2009, p. 56) atesta como "resultados pífios frente aos desafios cumpridos e à magnitude dos investimentos que são necessários”.

Entrementes, é imprescindível atentar para o tipo de concessão que se arbitra, considerando que esses projetos de outorga podem gerar falhas do Governo, irreversíveis ao setor. Assim, é preciso atentar para que as falhas do mercado não sejam substituídas pelas falhas do Governo, que diante de uma postura liberal, optou pela inação na regulamentação de setores estratégicos da economia do país.

O desenvolvimento do transporte aéreo se firma num momento em que a necessidade de planejamento, de políticas públicas para o transporte aéreo torna-se crucial para o crescimento do setor, inclusive em âmbito regional, como forma de promover a fluidez territorial a partir das redes e dos fixos instalados no Estado de São Paulo.

Baseados na argumentação da necessidade de planejamento destacamos que as políticas públicas do Governo devem prever a correspondente inter-relação entre a oferta e a demanda, o que consequentemente, induz a operacionalização das empresas, a dinâmica do mercado, a oferta do serviço de transporte aéreo à cidades com capacidade de geração de tráfego e para aquelas que não possuem acesso ao modal. 
Essas análises são questões que estão relacionadas e, que configuram um processo desencadeador da regulamentação, isto é, de medidas que visem o fortalecimento desse serviço nas cidades destacadas nessa pesquisa.

Desse modo, as políticas públicas precisam ser programadas mediante a oferta do transporte aéreo, uma vez que as empresas correspondem a estrutura de organização do mercado, sem as mesmas não há o transporte aéreo com fins comerciais. Analisar e programar o setor requer uma conciliação entre o que é interesse público, ou seja, o que beneficia a sociedade; e, o que é interesse privado, isto é, os interesses estratégicos das empresas.

Regulamentar para quem? Primeiramente, para o mercado, para as empresas, de forma a sintonizar a disponibilização do serviço, o custo-benefício, a acessibilidade, a atuação das empresas, a coerência na concorrência e na integração entre as empresas, objetivando, em seguida, o bem estar do usuário, seja em termos de segurança, acesso, preço, diversidade etc.

Assim, apontamos para o fato de que o potencial da capacidade aeroportuária paulista é composto por um conjunto de fatores que propicia a demanda de investimentos para uma maior dinâmica regional, uma vez que se trata de um crescimento sustentável, pois promove a melhor utilização das infraestruturas aeroportuárias ao invés de congestionar os grandes centros. Tudo isso reflete o grande potencial de crescimento da aviação regional no Brasil na atualidade (OLIVEIRA, 2009).

A mobilidade territorial baseada no transporte aéreo decorre da qualidade e quantidade de infraestrutura dos fixos. Assim, consideramos que a atuação estatal, combinada com o setor privado, em acordos de parcerias pode engendrar um processo desencadeador de novas perspectivas para a aviação comercial regional do Estado de São Paulo, no sentido de promover melhores condições infraestruturais aeroportuárias e, com isso, transformar aeroportos deficitários em pontos nodais importantes para o Estado, no intuito de contribuir para a dinâmica urbano-regional, bem como para a integração territorial e para a intensificação das interações espaciais, favorecendo, desta forma, o desenvolvimento econômico do interior de São Paulo. 


\title{
CAPÍTULO III
}

\author{
TRANSPORTE AÉREO REGIONAL NO \\ ESTADO DE SÃO PAULO: UMA ANÁLISE \\ SOBRE OS FLUXOS DE PASSAGEIROS
}


A análise sobre os fluxos aéreos no Estado de São Paulo pressupõe a constituição das redes do transporte aéreo, que neste trabalho é tomada mediante os nós do setor aéreo, isto é, as cidades e seus respectivos aeroportos. Desta forma, é imprescindível contextualizar o papel da formação da rede geográfica do setor aéreo paulista, bem como as interações espaciais promovidas e intensificas pelo circuito espacial da circulação.

Dentro dessa lógica, a contabilização dos dados enfoca a importância das ligações aéreas entre o interior e a capital e entre a capital e o interior do Estado. Assim, compreende-se o papel de articulação, contiguidade e/ou complementaridade expressa pelo interior na relação com a capital paulista e vice-versa. O papel desempenhado pela capital e pelo interior demonstram a interface existente no Estado, que pode ser melhor entendido quando se tem como parâmetro o processo de desconcentração urbanoindustrial (LENCIONI, 1994).

As redes de ligações aéreas refletem as concentrações de população e de riquezas no território, ligando as cidades brasileiras mais ativas em termos econômicos (REGIC, 2007). É dentro dessa perspectiva que o Estado de São Paulo funciona como uma rede de interconexão dos pontos no espaço. Apesar das redes serem projetadas hierarquicamente em razão da centralidade urbano-industrial, o Estado de São Paulo possui densidade técnica, ou seja, compreende uma organização técnica que as remetem na interface com a metrópole, reproduzindo o espaço urbano, no sentido da desconcentração, mas também num processo articulado de complementação regional, de contiguidade centro/interior e do interior/centro, formando, desta maneira, uma rede geográfica de conexões para o setor aéreo.

A configuração das redes geográficas manifesta as interações espaciais e a organização dos territórios e, assim, a conectividade das cidades representa a fluidez e a dinâmica social no espaço, projetadas a partir do circuito espacial da circulação. Corrêa (1997) argumenta que as interações espaciais fortemente regionais se devem à força de inércia das localizações estabelecidas no passado, na qual a distância desempenhava, mais do que atualmente, um papel determinante nas interações espaciais.

$\mathrm{O}$ autor considera que as interações espaciais processadas a partir da fluidez no território pelo transporte aéreo, refletem as redes geográficas como formas com que as interações se verificam. Assim, estabelece-se um elo de conexão entre as interações 
espaciais processadas em decorrência da infraestrutura e dos meios de transportes, inclusive pelo modal aéreo. Em síntese, as interações espaciais são processadas na lógica da variabilidade espaço-temporal, na qual a sociedade está inserida, aumentando ou diminuindo os padrões de interações.

Nessa mesma discussão sobre interações espaciais, Ullman (1972) destaca que o termo tem relação com a circulação; mas, para tanto, o autor esclarece que suas diferenciações são necessárias, uma vez que a circulação prescinde das relações de trocas, de reciprocidade, de demanda, de oferta etc., sendo, portanto, uma relação complementar, ou seja, a circulação complementa as interações espaciais, que por sua vez requer mobilizações, trocas, isto é, interação.

Baseando-se nessa prerrogativa, Ullman (1972) ainda assevera que a interação propriamente dita se dá entre os lugares quando há uma conexão entre eles, seja por meio dos transportes, das comunicações etc. Desta forma, afirma que para existir interação entre duas áreas, em uma delas deve existir demanda (demand) e em outra uma oferta (supply). Destacamos, nesse ínterim, que as interações espaciais existentes entre as cidades aqui tratadas, e destas com a capital, inserem-se no que o autor elucida como a validez da complementaridade entre os espaços.

Já para Beguin (1995), a análise da interação espacial é a relação entre os agentes habitualmente localizados em lugares diferentes. Com isso, o autor busca compreender as modalidades de intercâmbios identificando as condições que as regem. Destaca, ainda, que as interações espaciais são, evidentemente, muito importantes para a Geografia Econômica, pois as trocas contribuem para a formação de um espaço e para influenciar o padrão de interações existentes entre os lugares e os agentes econômicos. Para isso, considera que a Geografia dos Transportes é o ramo mais particular para a análise das interações espaciais.

Com isso, tem-se que as interações espaciais são materializadas pela circulação, que influi sobre a necessidade de bases, de pontos, ou melhor, de nós. Isso ocorre com o setor aéreo, que precisa da conformação das redes e de seus respectivos nós para circular e processar as interações espaciais.

As redes, por sua vez, constituem os nós interconectados, que requerem uma infraestrutura tecnológica, ou seja, suporte material que possibilite as interações 
espaciais e o crescimento do setor. Estas redes definem a função de regulamentação desses nós, na medida em que necessitam de fixos que promovam a fluidez.

Castells (2000) afirma que a lógica das redes gera uma determinação social em nível mais alto que a dos interesses sociais específicos expressos por meio das redes. Com isso, o poder dos fluxos é mais importante do que os fluxos de poder. Para o autor, a presença na rede ou a ausência dela na dinâmica de cada rede em relação às outras são fontes cruciais de dominação e transformação de nossa sociedade, que podemos apropriadamente chamar de "sociedade em rede" - caracterizada pela primazia da circulação, dos fluxos territoriais e dos fixos instalados.

Apesar das diversas e confluentes definições sobre o conceito de redes e a relação do conceito de rede e outras variáveis geográficas, nos detemos à especificação de Dias (2005); todavia, tal especificação está distante de revelar uma definição conceitual. A autora diz que a rede, como qualquer outra invenção humana, é uma construção da sociedade, alega que indivíduos, grupos, instituições ou firmas desenvolvem estratégias de toda ordem (políticas, sociais, econômicas e territoriais) e se organizam em rede, manifestando as interações espaciais nos territórios que estão circunscritos nas mesmas. Em síntese, entende-se que a rede não constituiu o sujeito da ação, mas expressa ou define a escala dos sistemas de ações e objetos, projetando a viabilidade para a circulação territorial.

Para Pons e Bey (1991, p. 64), "la forma en que cada área geográfica configura sus redes refleja el grado de desarrollo económico, de interacción espacialsocial, que cada una ha alcanzad." Nessa discussão sobre a organização espacial dos transportes e suas redes, Pons e Bey (1991) alegam que os transportes constituem um importante canal de produção das redes geográficas que promovem a circulação de bens e pessoas:

En la interrelación establecida entre los puntos, los canales de circulación y los flujos que por ellos transcurren se encuentra la noción de red (...), la forma en que se produce a interacción espacial en el mundo actual se explica gracias as las redes de transportes (PONS; REYNES, 2004, p. 185).

De acordo com Castells (2002), a organização da sociedade baseia-se na lógica espacial da circulação, o qual denomina de espaço de fluxos. Para o autor, a flexibilidade do espaço é decorrente da relação entre a sociedade e os fluxos, isto é, os agentes sociais estão envolvidos numa rede de fluxos que corresponde à organização 
material das práticas ou dos sistemas de ações. A rapidez e mobilidade das redes promovem a aproximação no espaço, produzindo e reforçando efeitos sociais e econômicos na medida em que também promovem a interação espacial ao permitirem o direcionamento dos fluxos nos territórios.

A contextualização sobre o conceito de redes foi aqui elucidada como forma de promover um conjunto de associações sobre o termo, tendo como intuito principal enfocar a rede geográfica do setor aéreo no Estado de São Paulo, bem como a configuração espacial desta rede, que tem a cidade de São Paulo como um centro de comando das interações e da integração territorial, que expressa, em última análise, o sentido do circuito espacial da circulação.

O setor de transporte aéreo regional no interior do Estado de São Paulo vem crescendo constantemente, mesmo em decorrência da necessidade de investimentos infraestruturais. Esse crescimento é mais intenso em centros urbanos mais desenvolvidos, que apresentam uma densidade demográfica mais expressiva e que possuem uma organização produtiva e econômica mais especializada, resultantes de suas formações territoriais.

No tocante a isso, Pons e Reynes (2004) destacam que:

La localización de los grandes sistemas aeroportuarios, asi como del mayor número de aeroportos les más alto rango, viene claramente relacionada con la localización de las mayores aglomeraciones urbanas, pero también, y en mayor medida, con las mayores aglomeraciones económicas (PONS; BEY, 1991, p. 62).

Desse modo, a ênfase dada às conceituações e análises de termos como "redes" e "interações espaciais" são abordadas neste trabalho, como forma de caracterizar o potencial aeroviário dos centros urbanos destacados, de modo a configurar uma análise sobre os fluxos aéreos entre as cidades supracitadas e a capital paulista.

Neste capítulo, será analisado quantitativamente e qualitativamente o setor aéreo regional em cidades paulistas que possuem aeroportos com voos regulares. Analisar-se-á a estrutura técnica das cidades e da região de influência, como forma de compreender o perfil socioeconômico que projeta e dinamiza o setor aéreo regional em determinados centros. Assim, temos como base a categorização dos aeroportos, realizada pela ANAC, que classifica os aeroportos por categorias, que variam de 1 a 4 
de acordo com os equipamentos que dispõem e de acordo com a infraestrutura dos fixos.

Embora essa classificação baseie-se no padrão operacional e confira às especificações técnicas do sistema aeroportuário internacional, mediante a OACI consideramos que tal classificação é consubstanciada por intermédio do perfil econômico traçado por estas cidades, ou seja, os centros urbanos que possuem uma melhor dinâmica urbana configuram centros de maior projeção para o setor aéreo regional, o que, consequentemente, reflete nas condições de infraestrutura dos aeroportos, na demanda de passageiros pelo modal, nos fluxos, bem como na atração de empresas aéreas na operacionalização da malha de voos.

\subsection{Transporte aéreo regional e as novas territorialidades: a viabilização do segmento regional}

$\mathrm{Na}$ análise elaborada neste trabalho, referimo-nos à utilização do termo "transporte aéreo regional" que decorre da história da aviação comercial brasileira, que tem como objetivo fazer referência ao transporte aéreo que interliga localidades do interior e estas com centros urbanos/capitais (BNDES IV, 2002). Nesse contexto, consideramos, igualmente, o transporte aéreo regional como aquele que interconecta os espaços urbanos, estabelecendo, assim, a intensidade das relações sociais e econômicas no interior do Estado de São Paulo.

Simões (2003) define o segmento doméstico regional como sendo aquele que compreende linhas regionais de rotas domésticas de pequeno curso, que servem de afluência e são complementares às linhas aéreas nacionais, isto é, funcionam como alimentadoras das principais linhas nacionais e internacionais. No entanto, essas linhas podem apresentar demanda razoável, o que as torna dinâmicas e movimentadas, no que se refere ao número de passageiros transportados.

Baseado nessa assertiva tem-se que o transporte aéreo subdivide-se em dois ramos, quais sejam: os voos regulares e não regulares. Simões (2003) analisa esses dois segmentos diferenciando-os da seguinte forma:

- Voos Regulares: compreendem os serviços aéreos sistemáticos, que são organizados na forma de linhas aéreas e são operados pelas companhias aéreas. Esses serviços são operados em regime de concessão pública pelo prazo de 15 anos, com possibilidade de renovação. O segmento aéreo regional está constituído em HOTRAN 
correspondente. Os voos regulares compreendem a ligação aérea entre duas ou mais localidades, caracterizadas por um número, por meio do qual é executado serviço regular de transporte aéreo, de acordo com horário, linha, equipamento e frequência.

Nesse sentido, o autor assevera que em torno de $85 \%$ das operações de transporte aéreos no Brasil são realizadas pelas empresas regulares, distribuídas em: 1) serviços regionais, que reúnem as companhias que atuam exclusivamente no mercado doméstico, principalmente nas linhas de pequeno curso e 2) transportes nacionais, responsáveis pelas operações domésticas de longo curso (interestaduais) e rotas internacionais.

- Voos Não-Regulares: referem-se ao conjunto das atividades de transportes aéreos realizados por meio de permissão ou autorização. Exemplos dessa modalidade são os voos charter (aluguel), os fretamentos (geralmente por operadoras de turismo) e os serviços de táxi aéreo. Os voos não regulares são operados por companhias aéreas especializadas ou pelas próprias empresas aéreas regulares, mediante demanda pelos serviços.

No Estado de São Paulo, 23 (vinte e três) aeroportos realizam o transporte aéreo não regular, tais como os aeroportos das cidades de Andradina, Araraquara, Assis, Avaré/Arandu, Barretos, Botucatu, Bragança Paulista, Campinas/Amarais, Dracena, Franca, Itanhaém, Jundiaí, Lins, Ourinhos, Penápolis, Piracicaba, Presidente Epitácio, São Carlos, São Manuel, Sorocaba, Tupã, Ubatuba e Votuporanga.

Mesmo na categoria não-regular, o transporte aéreo regional tem demonstrado um constante crescimento no número de passageiros transportados, mas, esse fato não tem sido suficiente para o Governo investir na infraestrutura destes fixos, o que promoveria a adequação em segurança dos voos no transporte de passageiros, além de contribuir para uma maior integração territorial. Os Quadros 1 e 2 exemplificam a quantificação de passageiros transportados por voos regulares e nãoregulares no Estado de São Paulo como forma de demonstrar o crescimento do setor no início da década de 1990 e nos anos de 2000 a 2007. 


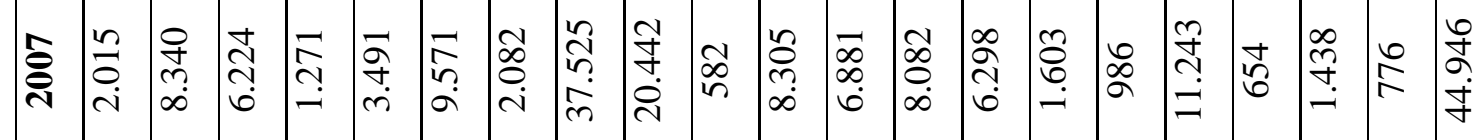

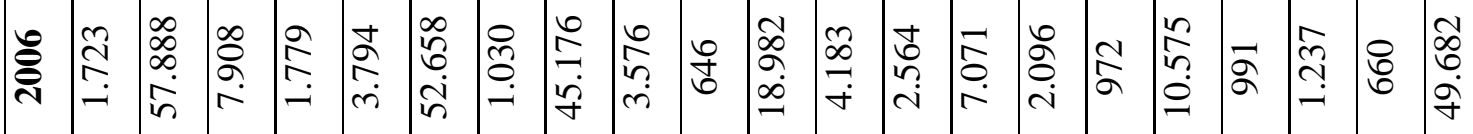

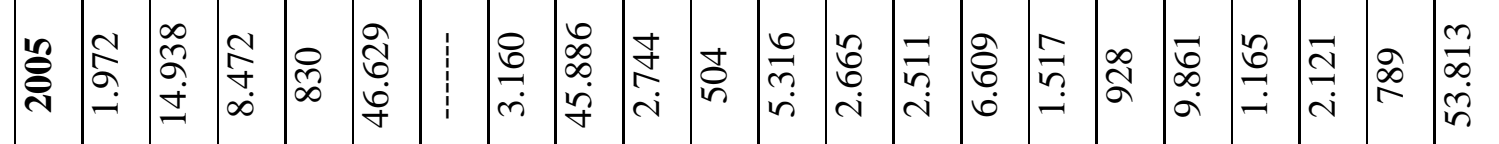

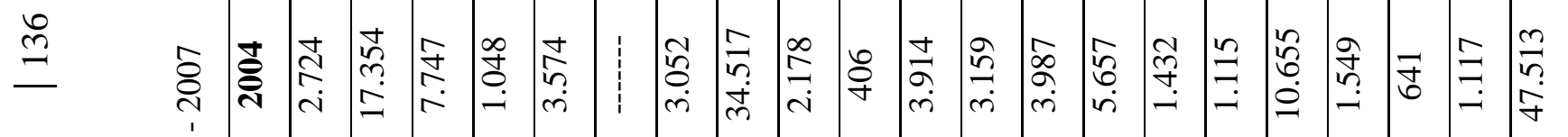

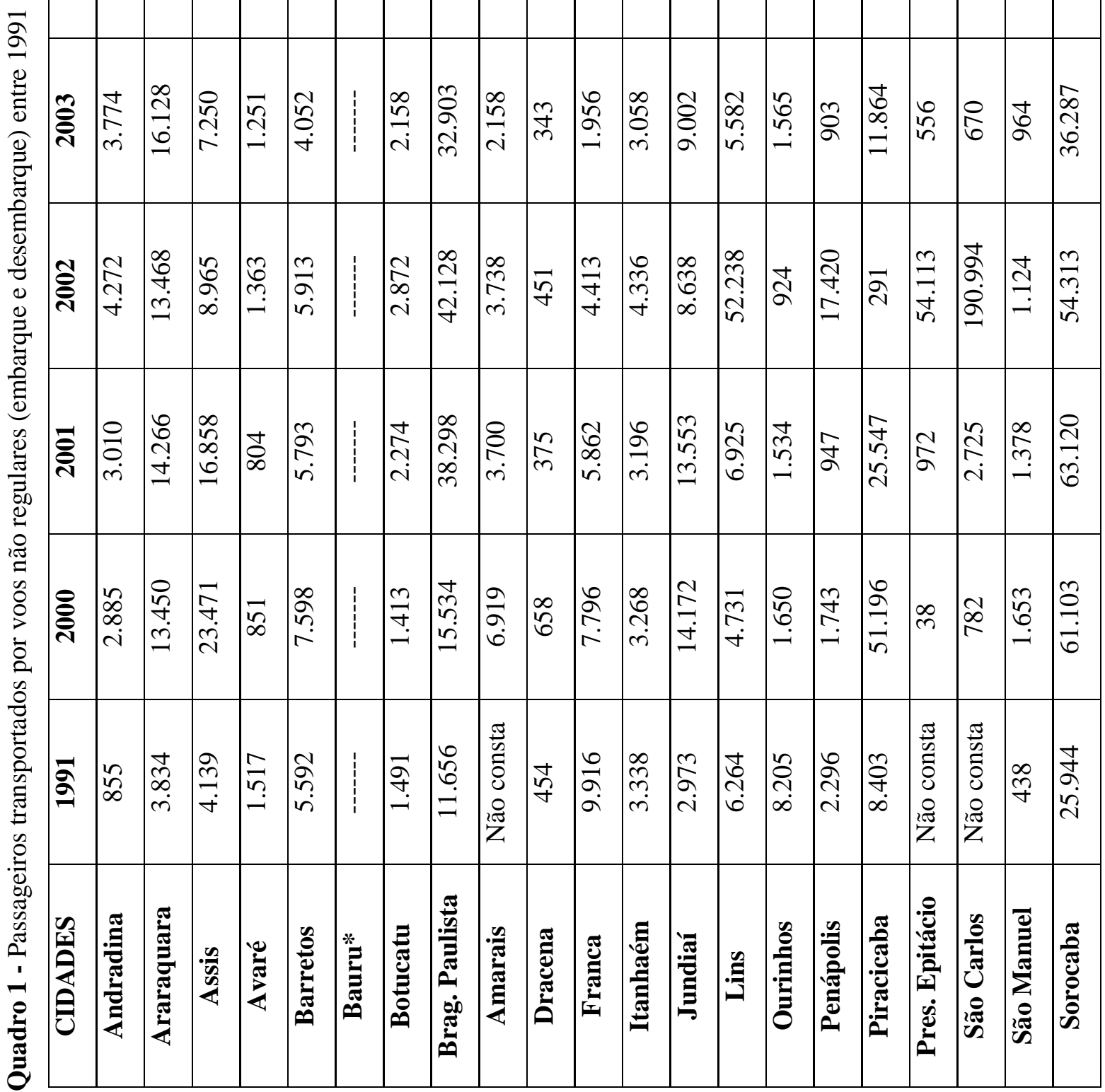



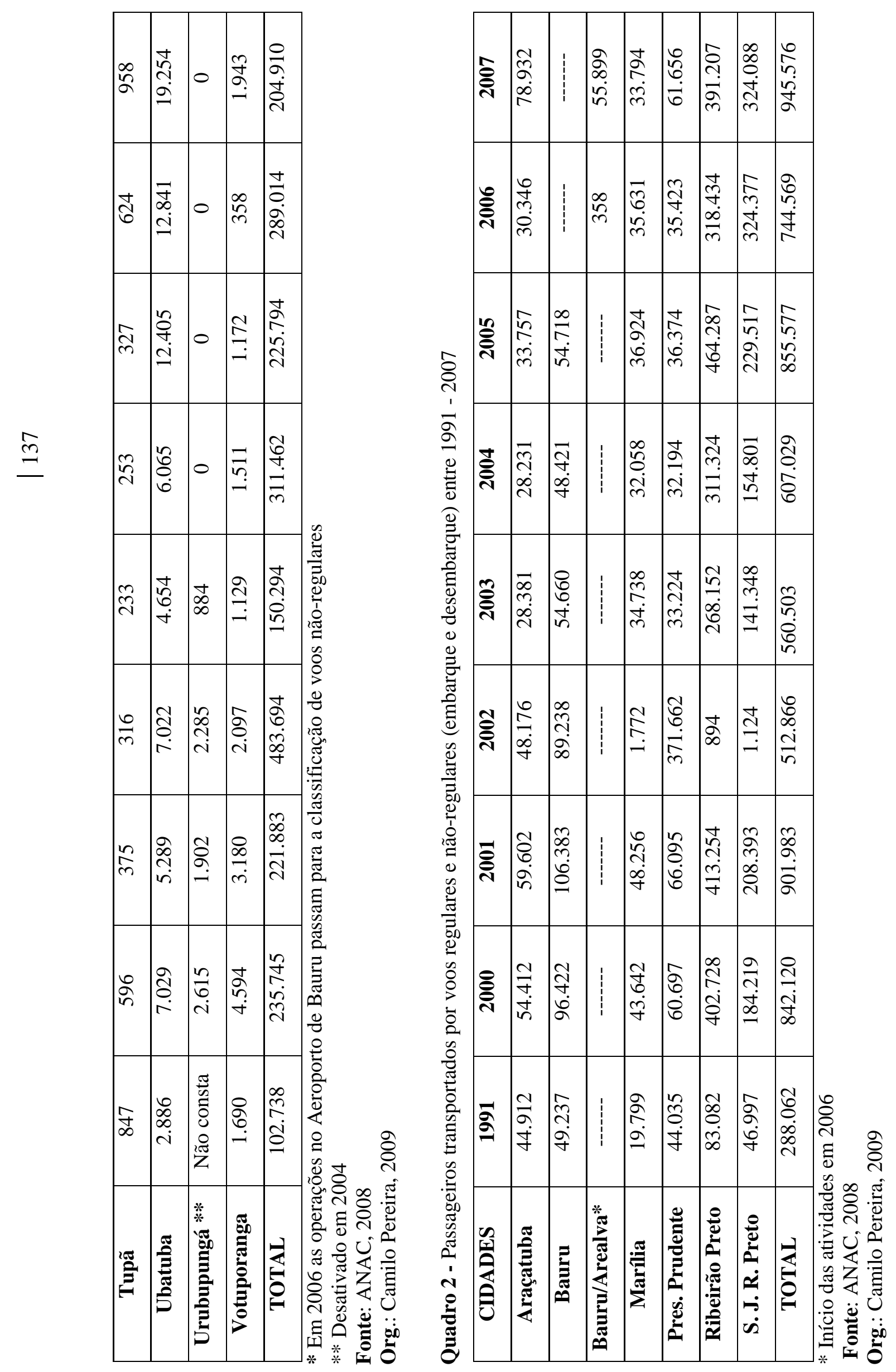
No entanto, cabe salientar que, dos 31 aeroportos que correspondem à administração estadual, isto é, do DAESP, apenas seis possuem autorização para operarem voos regulares (Quadro 2). Esta questão está ligada ao que os órgãos competentes consideram como ausência da demanda pelo segmento aéreo regional. Constatamos que foram feitos testes com empresas aéreas regulares, tais como a Air Minas Linhas e a Oceanair Linhas Aéreas, em cidades que possuem aeroportos, como Assis e Tupã. Mas estes aeroportos não obtiveram retorno em relação à demanda mínima exigida para a determinação de voos regulares.

Nossa abordagem recai sobre a análise dos voos regulares no transporte de passageiros. No tocante a isso, consideramos que a análise evidenciada busca contribuir para a compreensão sobre o transporte aéreo regional, bem como para o desenvolvimento e crescimento do setor. Nessa perspectiva, compreendemos que a autenticidade dos dados disponíveis é essencial em tal análise e, portanto, a coerência estabelecida neste trabalho redunda na apreciação de voos regulares, devido ao fato de estes enquadrarem-se nos serviços prestados por empresas aéreas regulares e, também, por representarem, de forma sintética, a abordagem que se busca elucidar.

O desenvolvimento do transporte aéreo regional, reflexo das redes que conectam os espaços (DIAS, 2005), afirma-se como uma forma imediata de fluidez territorial. Nesse sentido, é essencial um sistema bem articulado de transporte aéreo, que se consubstancie pela sua principal característica, isto é, a supressão do espaço pelo tempo (HARVEY, 2006) e que, para isso, possibilite a conexão entre pontos diversos do território paulista. Tal afirmação não significa dizer que o Estado deve se comprometer com a eficiência de 31 aeroportos (regulares e não-regulares) existentes no Estado de São Paulo, até porque, como podemos observar no desenvolvimento desta pesquisa, não há demanda oriunda e destinada para esse número de aeroportos. Mas significa argumentar que o Estado tem como obrigatoriedade viabilizar, no mínimo, as condições infraestruturais destes fixos estratégicos que possuem demanda condizente com a necessidade de investimentos e de planejamento aeroviário.

Neste trabalho, propomos uma leitura sobre o transporte aéreo regional no Estado de São Paulo, considerando sua importância em âmbito econômico para a promoção do desenvolvimento regional e para a intensificação das interações espaciais. Para tanto, tomamos como condição intrínseca ao sistema aeroviário a articulação aérea com o segmento regional, como uma possível alternativa para o "descongestionamento" dos aeroportos centrais, mediante a constituição de hubs secundários, mas também como fomento ao desenvolvimento e crescimento do setor aéreo regional e do interior paulista. 


\subsection{A multiplicidade dos fluxos aéreos no interior do Estado de São Paulo: uma abordagem da rede urbana e das regiões de influência das cidades}

No exame sobre a origem e destino das ligações aéreas no interior do Estado de São Paulo, notamos que os fluxos perfazem percursos entre as principais cidades analisadas e, sobretudo, na conexão com a capital paulista.

Esse fato é observável, também, no restante do país. A capital paulista engendra a maior movimentação de passageiros no Brasil. Indiscutivelmente, este fato é destacado nas ligações aéreas que têm origem, destino ou conexões/escalas nos aeroportos centrais do Estado. Tal ocorrência favorece, também, os aeroportos regionais que acabam sendo beneficiados pelos fluxos e pelos deslocamentos de passageiros, uma vez que constituem as ligações secundárias no Estado.

O estudo sobre as Regiões de Influência das Cidades (REGIC) destaca que São Paulo chama a atenção como centro concentrador de fluxos, não apenas por ser um $h u b$ da aviação comercial, gerando conexões para diversas áreas do Brasil, mas, também, por ser o principal destino direto de passageiros e carga, em virtude de motivos históricos de concentração de população na metrópole e pela diversificação das atividades econômicas. Ao observar as ligações aéreas no Brasil (Mapa 2), nota-se que há uma centralização da estrutura de fluxos no Estado de São Paulo.

Théry (2003) argumenta que os mapas de fluxos aéreos desenham de maneira muito clara as redes hierarquizadas; o mesmo destaca ainda, a estrutura de centralização econômica e política do país, concentrada em São Paulo. Além disso, a configuração espacial do tráfego aéreo reflete bem a lógica geral da organização territorial brasileira. Isso se dá em razão dos níveis de centralidade do Estado e, principalmente, da metrópole paulista, que agrega uma função primordial em todos os elementos que constituem a rede urbana do Brasil, quais sejam: o tamanho, a organização e a complexidade.

Tal elucidação é melhor observável quando se analisa as redes e os respectivos nós do transporte aéreo no Brasil (Mapa 2). Nota-se que há uma interconexão via aérea bem articulada no país. Percebe-se que o Estado de São Paulo constitui-se como um nó da rede geográfica estratégica para o transporte aéreo que projeta hierarquicamente a maior demanda de fluxos, concentrando a operacionalização dos voos.

A partir da ilustração que se segue, observamos que os fluxos são mais densos na região Centro-Sul, com destaque para o Estado de São Paulo. Conforme se afasta dessa região concentrada, os fluxos tornam-se mais rarefeitos, confirmando o que chamamos de “concentração centralizada" dos fluxos aéreos no Brasil. 


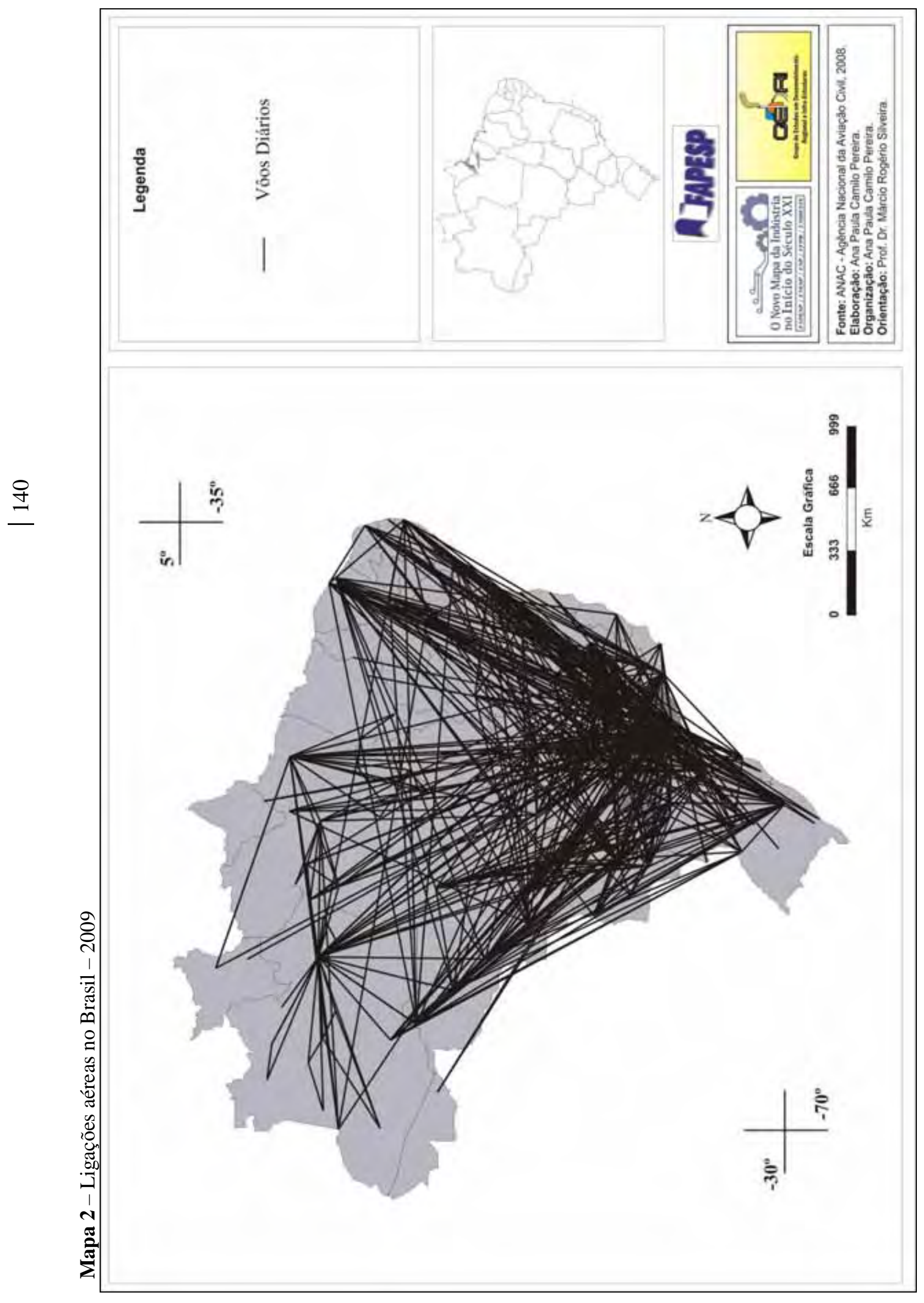


Nesse sentido, a base de dados demonstrada a seguir nos cartogramas enfoca as rotas realizadas pelas empresas aéreas nas cidades e o número de passageiros transportados por ano, no período de 1995 a 2007. Este recorte temporal foi definido para a pesquisa por compreender um período posterior ao início do processo de desregulamentação, caracterizando assim os resultados socioespaciais e as implicações econômicas para o setor aéreo.

Os dados apresentados foram agregados por municípios e referem-se às ligações aéreas produzidas pelas cidades analisadas, nos percursos desenhados entre estas e destas com a capital do Estado. Apesar de ter como recorte espacial estas cidades, os cartogramas mostram que há ligações aéreas de alguns centros urbanos com o Aeroporto de Viracopos, na cidade de Campinas. Embora esteja localizado no interior do Estado, este aeroporto não foi definido para a análise da pesquisa, por compreender um sistema aeroportuário hierarquicamente superior aos aeroportos mencionados e por ser considerado um hub internacional na aviação comercial brasileira.

É importante destacar, também, que a densidade de passageiros transportados com origem nas cidades com aeroportos regulares do interior paulista para Campinas não é comparável ao fluxo destinado aos aeroportos de Congonhas e Guarulhos/Cumbica. Todavia, os dados são demonstrados, como forma de elucidar todas as ligações aéreas no Estado de São Paulo que foram realizadas no período pesquisado.

O procedimento metodológico adotado para análise dos fluxos aéreos no Estado de São Paulo é baseado nos dados dos Anuários Estatísticos divulgados pelos órgãos de gestão e controle do tráfego aéreo no Brasil, como a ANAC, a INFRAERO e o DAESP. Os cartogramas expressam quantitativamente, a partir de uma matriz de origem/destino, a intensidade das interações espaciais processadas pelas cidades anteriormente mencionadas a partir do circuito espacial da circulação aérea e, ainda, enfoca o nível de interação entre as cidades, sobretudo destas com a capital São Paulo, principal linha executada pelas companhias aéreas.

Baseamo-nos, ainda, na interpretação do IBGE e em seus estudos sobre as Regiões de Influência das Cidades (REGIC) concernentes às conexões aéreas. Assim, temos que esta metodologia circunscreve-se a partir das interpretações da teoria dos grafos, que, segundo o REGIC, estudam as propriedades topológicas de ligações entre elementos, incorporando conceitos de fluxos dominantes, cidade independente, cidade subordinada e transitividade das ligações. 
Os níveis de centralidade exemplificados pelo REGIC partem de um conjunto de atividades que elenca os mais diversos setores. Em razão da complexidade deste estudo, abordaremos na pesquisa apenas os dados referentes aos fluxos aéreos que constituem a temática elaborada e que projetam uma dimensão da circulação territorial e dos fluxos aéreos em acordo com a rede urbana.

Desta forma, cabe pormenorizar as diferenciações teorizadas pelo REGIC, no que diz respeito aos conceitos sobre as cidades a partir do circuito espacial da circulação aérea. Nessa perspectiva, aborda-se o nível hierárquico da rede aérea geográfica dos centros urbanos, baseados apenas para os fluxos aéreos, de acordo com o tamanho da cidade ${ }^{44}$. Para tanto, propomos uma avaliação da rede urbana em duas dinâmicas distintas: de um sistema de localidades centrais que comanda sua hinterlândia e a de um sistema de cidades articuladas em redes.

Com isso, temos que as cidades estudadas compreendem essas duas dinâmicas, pois ora processam-se como localidades centrais, capazes de fomentar o comando de sua região de influência imediata, ora perfazem um complexo sistema de cidades articuladas em rede, dinamizando a estrutura dos fluxos aéreos pelo Estado.

Dentro dessa prerrogativa, tem-se que estas cidades constituem-se no conjunto denominado de "capitais regionais". A descrição dessa tipologia é explicada a partir da informação de que as capitais regionais têm a capacidade de gestão em nível imediatamente inferior ao das metrópoles e, no entanto, têm uma área de influência de âmbito regional, sendo referidas como destino de um conjunto de atividades ${ }^{45}$. Em outras palavras, as capitais regionais possuem uma estrutura topológica que as permite influir e engendrar relações de complementaridade com as cidades de nível superior, no caso a metrópole paulista, assim como exercer influência em seu entorno (nível inferior) mediante, sobretudo, a projeção da dinâmica dos fluxos, isto é, a necessidade de deslocamento territorial.

Assim, aponta-se que, teoricamente, uma cidade é considerada independente se apresentar o maior fluxo ${ }^{46}$, o dominante, direcionado a um centro menor. A cidade subordinada é caracterizada como aquela que apresenta ligação aérea de maior valor com um centro maior. E o município é analisado como transitório se há um encadeamento de

\footnotetext{
${ }^{44} \mathrm{~A}$ classificação de duas cidades em um mesmo nível hierárquico não implica semelhanças demográficas ou funcionais, mas apenas que, topologicamente, ambas ocupam a mesma posição na rede (REGIC, 2007).

${ }^{45}$ Essa situação é resultado da desconcentração urbano-industrial.

${ }^{46}$ Entende-se como maior fluxo aquele que apresenta o maior número de passageiros e uma maior frequência/dia dos fluxos.
} 
subordinações no qual uma cidade é secundária a outra, que é subordinada a uma terceira, então a primeira também será considerada como subordinada à última (REGIC, 2007).

A avaliação elucidada demonstra que as cidades aqui analisadas são consideradas subordinadas, uma vez que todas apresentam o maior fluxo, ou seja, o dominante, direcionado à capital metropolitana. Todavia, é válido destacar que a definição do REGIC não aprofunda o estudo sobre o processo hierárquico no sistema aéreo paulista. Ressaltamos que tal abordagem refere-se, genericamente, ao processo de quantificação e qualificação da rede urbana brasileira, tendo o transporte aéreo como um elemento para análise, o que não resulta, necessariamente, em uma demonstração específica e realista do setor aéreo no Estado de São Paulo. Um exemplo de como o REGIC não aprofunda uma análise mais realista sobre o setor aéreo é verificado na análise de algumas cidades, tal como Ribeirão Preto, que já desponta no mercado aéreo como um hub regional, passando assim a ser considerada independente, em termos de ligações com outros centros urbanos menores.

Portanto, consideramos as abordagens do REGIC como uma análise complementar de avaliação realizada sobre as ligações aéreas no interior do Estado de São Paulo. Contudo, a base de dados apresentada nesta pesquisa tem como parâmetro uma análise própria sobre o transporte aéreo regional paulista, que considera as interligações aéreas como um processo configurador das interações espaciais.

Desta forma, iniciamos apurando os dados que correspondem aos aeroportos de Araçatuba, Bauru, Marília, Presidente Prudente, Ribeirão Preto e São José do Rio Preto na conexão entre esses aeroportos e com o Aeroporto de Congonhas ${ }^{47}$, e, se necessário, com o Aeroporto de Viracopos em Campinas. Posteriormente, é demonstrado um cartograma que indica os voos regulares regionais da cidade de São Paulo em direção ao interior paulista. Computa-se, também, nesses cartogramas, o número de passageiros transportados.

Para isso, são utilizados os dados econômicos e estatísticos da Fundação Sistema Estadual de Análise de Dados Estatísticos (SEADE), do Instituto de Pesquisa Econômica Aplicada (IPEA), da publicação do REGIC e os dados do IBGE, como forma de caracterizar o perfil econômico regional de cada centro urbano, tendo sempre como base as cidades já mencionadas neste capítulo e suas regiões de influência imediata. A codificação dos dados baseou-se na elaboração do software Philcarto, que possibilitou elaborar cartograficamente os mapas de fluxos aéreos.

\footnotetext{
${ }^{47}$ O Aeroporto de Congonhas recebe e destina voos regulares regionais no Estado de São Paulo, sendo o Aeroporto de Guarulhos/Cumbica utilizado apenas pela empresa Passaredo Linhas Aéreas.
} 
Assim, apresentamos a seguir um panorama elucidativo das cidades pesquisadas, abordando suas principais atividades econômicas (fator, este, que agrega valor a funcionalidade do transporte aéreo), os aeroportos (sistemas de objetos e/ou fixos) e os fluxos aéreos no período referendado.

\subsubsection{Araçatuba}

A cidade de Araçatuba está localizada na $9^{\mathrm{a}}$ Região Administrativa (RA) do Estado e polariza dezenas de municípios de seu entorno. Possui uma população de 178.839 habitantes (IBGE, 2009). Localizada no Centro-Oeste paulista, caracteriza-se por suas funções de pólo regional e configura-se como um importante centro prestador de serviços e comércio. De acordo com a caracterização regional realizada pelo SEADE, a Região Administrativa de Araçatuba é composta por 43 municípios, sendo os principais Araçatuba e Birigui.

Araçatuba tem seu desenvolvimento urbano e econômico ligado à constituição da Estrada de Ferro Noroeste do Brasil (SEADE, 2008), que orientou uma incipiente organização territorial ainda no século passado. Seu desenvolvimento econômico, desde sua criação, e em razão da circulação territorial que sempre a destacou como um importante elo de escoamento da produção paulista, consolidou a cidade como centro regional que polariza os municípios de seu entorno. Hoje, desenvolvem-se na cidade atividades de comércio e serviços variados, como saúde e educação.

Conhecida como a "Capital do Boi Gordo", Araçatuba é importante centro estadual de comercialização de bovinos e de insumos e equipamentos para a pecuária, que é a principal atividade econômica desenvolvida no município. Destaca-se, ainda, o volume de negócios de matrizes e reprodutores e a existência de pólo genético de sêmen produtor (SEADE, 2008).
A aglomeração urbana de Araçatuba e seu entorno são conhecidos, sobretudo por ter-se voltado, historicamente, para a pecuária, resultando daí uma ocupação esparsa do território. Ainda hoje, Araçatuba é o principal centro estadual de comercialização de bois, com o título de "capital do boi gordo", muito em virtude da especialização progressiva da atividade paulista na engorda e no abate (IPEA, 2001, p. 137).

Araçatuba possui cinco importantes sistemas de transportes que estão envoltos à malha da cidade, tais como: o Aeroporto de Araçatuba, a Hidrovia Tietê-Paraná, a Rodovia Marechal Rondon, a Ferrovia Noroeste do Brasil e o Gasoduto Brasil-Bolívia. A caracterização da economia regional de Araçatuba registra que a boa estrutura viária transformou a cidade em uma rota de passagem de parte do tráfego destinado a outros Estados, como para o Mato Grosso do Sul e Mato Grosso. 
De acordo com os dados do IPEA, Araçatuba tem conhecido um grande processo de transformação, resultado da reestruturação econômica com a qual o município convive desde os anos de 1990. Os setores de transportes são responsáveis por parte dessas transformações, como no caso da Hidrovia Tietê-Paraná ${ }^{48}$, que tem contribuído com a atração de novos empreendimentos voltados para as áreas de agricultura, pecuária, indústrias, comércio e serviços.

O gasoduto Brasil-Bolívia, do qual Araçatuba é rota, incrementa outro fator relevante para o desenvolvimento econômico regional. A cidade possui uma oferta de energia que perfaz a possibilidade da utilização da multimodalidade no transporte de mercadorias.

Todos esses fatores fazem com que Araçatuba atraía um contingente expressivo de pessoas que se dirigem até a cidade em busca das atividades econômicas realizadas e desenvolvidas nela e nos municípios vizinhos. Para isso, o modal aéreo consubstancia-se como um importante meio de mobilidade, sobretudo para aqueles que se encontram na capital paulista e que desenvolvem atividades econômicas na cidade.

Embora o Aeroporto de Araçatuba apresente um baixo potencial de fluxos aéreos de passageiros, em comparação com os demais aeroportos regionais, a cidade possui um dos melhores sítios aeroportuários do Estado, já que está localizado fora da cidade, - fator, este, que favorece a ausência de obstáculos - e, também, por fazer parte do potencial de transportes da região.

O município abriga o Aeroporto Estadual Dario Guarita (Foto 9), que, segundo a ANAC, está na categoria 3. As operações aéreas são realizadas 24 horas; o setor de comunicação é controlado pela Rádio Pantanal, que é um comando de comunicação aérea particular da empresa Pantanal Linhas Aéreas ${ }^{49}$.

\footnotetext{
${ }^{48}$ Ver Felipe Jr (2008).

${ }^{49} \mathrm{~A}$ rádio opera das 6 às 10 da manhã e nos horários em que a empresa Pantanal opera seus voos. Nos demais horários em que a Rádio Pantanal não opera, caso alguma empresa necessite operar no Aeroporto de Araçatuba, é solicitado previamente, para que haja uma organização do sistema operacional.
} 
Foto 9 - Aeroporto de Araçatuba - 2006

\section{Aeroporto de Aracatuba}

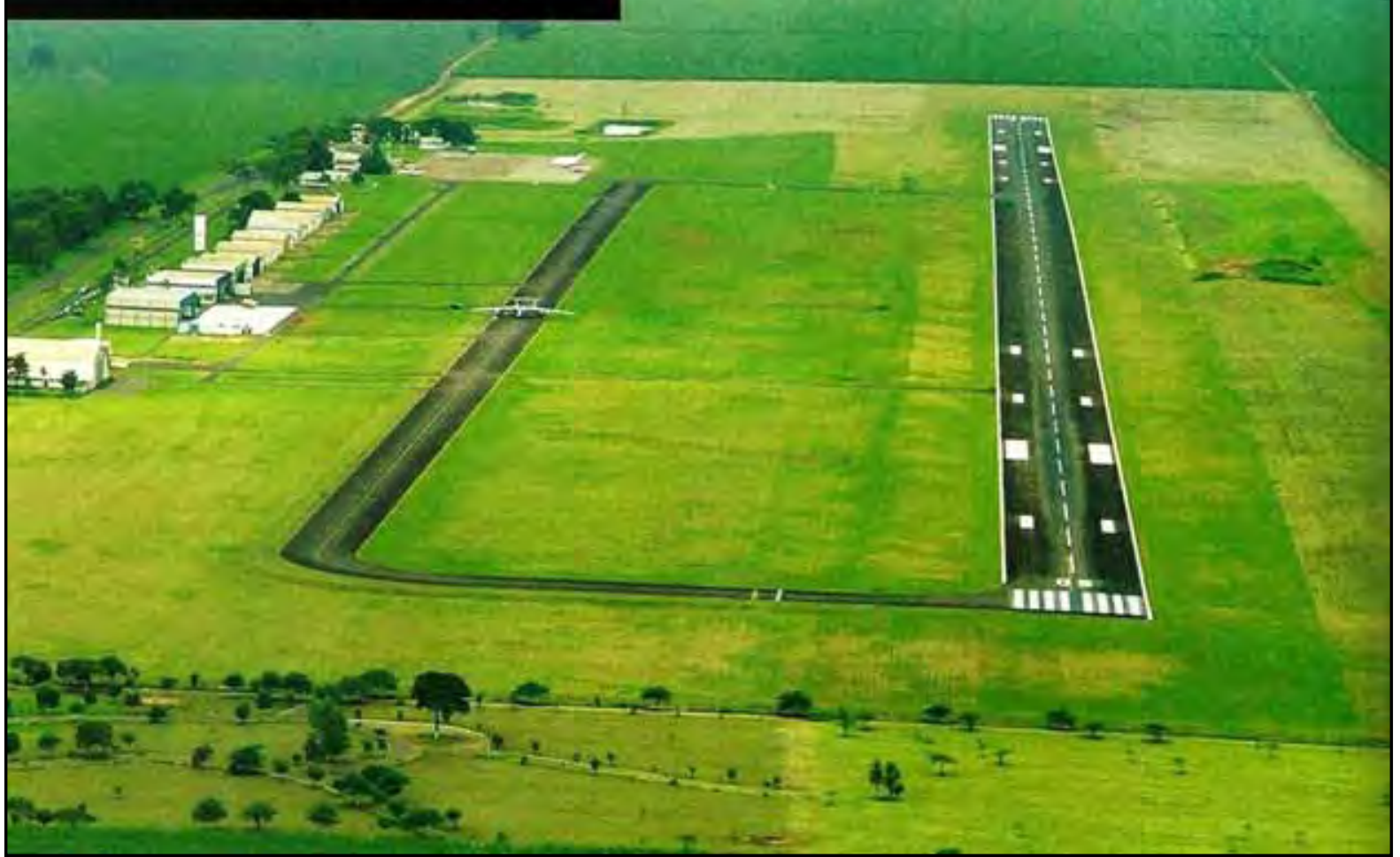

Fonte: Revista Aeroportos do DAESP, 2006

As operações aeroviárias ocorrentes no aeroporto são realizadas apenas pela empresa Pantanal Linhas Aéreas. Tal fato tem prejudicado a aviação comercial na cidade, que não dispõe de concorrência entre empresas. No ano de 2007, Araçatuba contava com as operações da empresa Air Minas Linhas Aéreas, que paralisou suas atividades em razão da reestruturação da empresa, que transferiu seus equipamentos para o Estado de Minas Gerais. No início do ano de 2008, a Oceanair Linhas Aéreas encerrou suas atividades no Aeroporto de Araçatuba, alegando problema de demanda.

Observa-se que a ausência de empresas no Aeroporto de Araçatuba está ligada à demanda pelo transporte aéreo, que é escassa, e também, devido os problemas de infraestrutura do aeroporto. No entanto, observa-se que esse encadeamento de fatores, ou seja, a demanda-oferta é resultado único da falta de opção dos usuários, que não dispõem de um sistema aéreo competitivo e de potencial geração de fluxos. Tais fatores estão atrelados ao planejamento das empresas em conjunto com o Estado e, também, concernem à ausência de concorrência das empresas aéreas. 
A partir das entrevistas e das visitas realizadas no aeroporto, nota-se que na ausência de opções de preços, os usuários, embora despendam de mais tempo em seus deslocamentos, têm optado pelo transporte rodoviário (ônibus) e/ou transporte individual (carros), em razão da ineficiência da empresa operadora no aeroporto de Araçatuba, que nos últimos anos tem diminuído a frequência de voos com origem no aeroporto. Isso prejudica a aviação comercial na cidade e, ainda, afeta o potencial econômico regional de Araçatuba.

Com apenas uma empresa aérea operando voos na cidade, os fluxos aéreos são poucos e não há uma diversificação de destinos. A empresa possui voos diretos e com escala para a capital paulista (Quadro 3). O aeroporto recebe voos da capital, que também realizam escalas em Bauru/Arealva e voos diretos para a cidade de Bauru.

Quadro 3 - Programação de voos do Aeroporto de Araçatuba - 2008

\begin{tabular}{|c|c|c|c|c|}
\hline \multicolumn{5}{|c|}{ Decolagens } \\
\hline Empresa & Voos diários & Origem & Escala & Destino \\
\hline Pantanal & 2 & Araçatuba & Bauru/Arealva & São Paulo \\
\hline Pantanal & 1 & Araçatuba & Não & São Paulo \\
\hline Pantanal & 1 & Araçatuba & Não & Bauru/Arealva \\
\hline \multicolumn{7}{|c|}{ Pousos } \\
\hline Empresa & Voos diários & Origem & Escala & Destino \\
\hline Pantanal & 2 & São Paulo & Bauru/Arealva & Araçatuba \\
\hline Pantanal & 1 & São Paulo & Não & Araçatuba \\
\hline Pantanal & 1 & Bauru/Arealva & Não & Araçatuba \\
\hline
\end{tabular}

Fonte: Trabalho de campo, 2008

Org.: Camilo Pereira, 2009

O Aeroporto de Araçatuba apresenta uma demanda de passageiros menor do que as demais cidades que operam voos regulares no Estado. O número de passageiros transportados expressa que a principal ligação aérea de Araçatuba é com a capital paulista. A partir dos mapas seguintes, nota-se que, no período analisado, a menor intensidade dos fluxos deu-se com as cidades de Marília e Ribeirão Preto. No direcionamento dos fluxos, a cidade de Marília representa um destino que perfaz um pequeno número de passageiros deslocados (836 passageiros). Com a cidade de Ribeirão Preto, Araçatuba apresentou ligações aéreas apenas no ano de 1999, transportando 997 passageiros, número pouco expressivo quando comparado às demais ligações de Araçatuba com outras cidades do Estado, tais como Presidente Prudente (22.260) e Bauru (19.334).

Cabe destacar que o ano de 2007 foi o mais representativo para as ligações aéreas com origem em Araçatuba, o que também é verificado nas ligações aéreas das demais 
cidades. A intensidade das interações espaciais tornou-se mais expressiva em 2007 quando foram embarcados 35.972 passageiros no Aeroporto de Araçatuba. Observa-se que, desse montante, 25.147 passageiros tinham como destino final a cidade de São Paulo. Nesse ano, o Aeroporto de Araçatuba registrou a $3^{\mathrm{a}}$ maior movimentação de passageiros dentre os aeroportos do interior de São Paulo.

A seguir, a Coletânea de mapas 3 representa cartograficamente o número de passageiros transportados com origem no Aeroporto de Araçatuba e com destino para as demais cidades paulista, enfatizando, assim, os fluxos aéreos com origem em Araçatuba e suas interfaces no período de 1995 a 2007. 


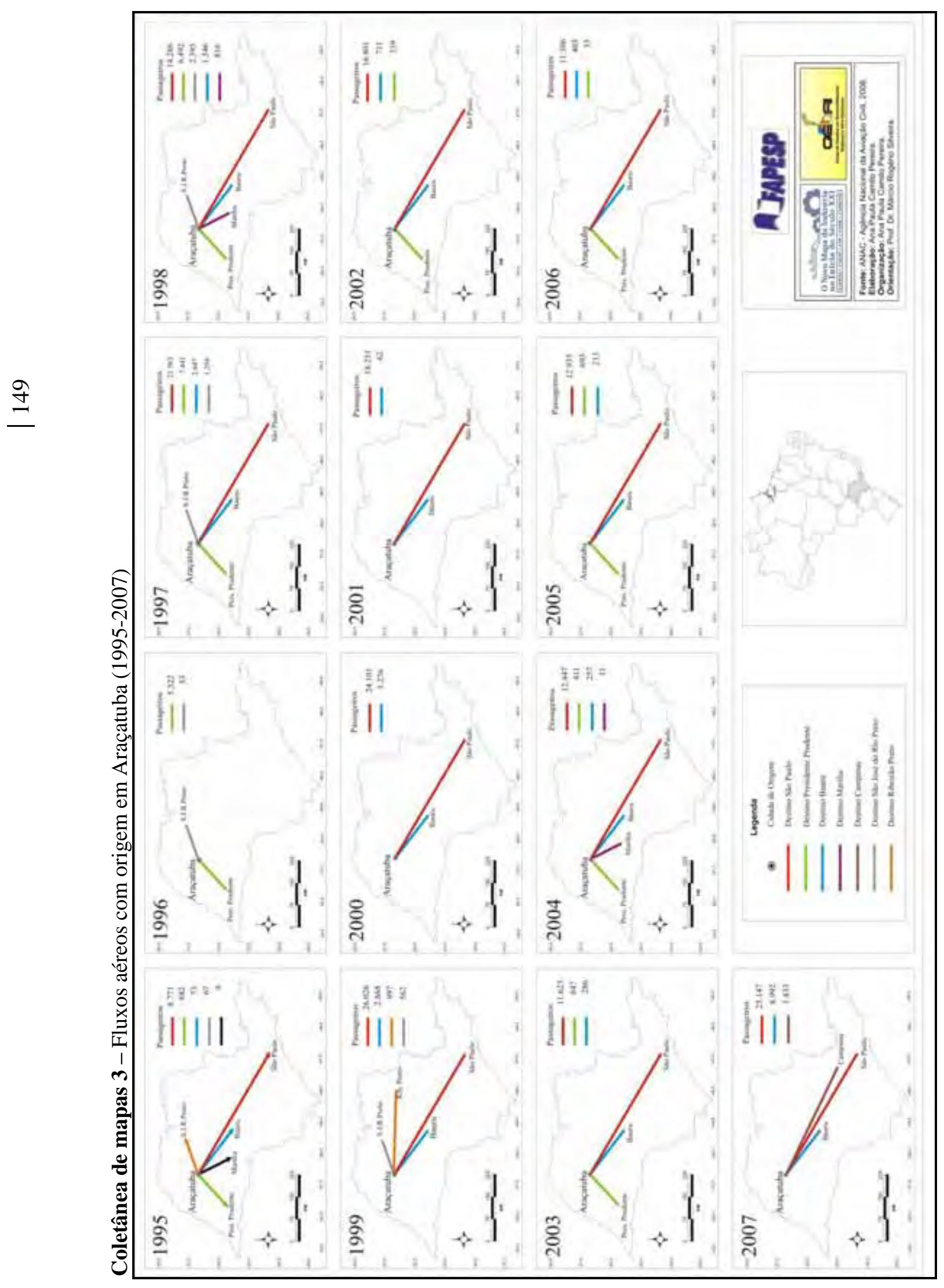




\subsubsection{Bauru/Arealva}

A cidade de Bauru é sede da $7^{\text {a }}$ Região Administrativa do Estado de São Paulo. A RA de Bauru é composta por 39 municípios. A cidade exerce influência num raio que atinge municípios de outras regiões administrativas próximas a ela (SEADE, 2008). Bauru caracteriza-se por ser uma das cidades mais promissoras do interior do Estado de São Paulo, além de ser rota aeroviária para demais cidades e também de outros Estados. Assim, Bauru configura-se como um importante entreposto comercial no Estado, devido, sobretudo, à logística operada pela cidade, que vem atraindo novos investimentos (IPEA, 2001).

O desenvolvimento econômico da cidade é constituído pela complementação regional que exerce em seu entorno, a exemplo de importantes centros urbanos do Estado de São Paulo, como Botucatu, que está a 92 km de distância, Marília, distante 106 km, e Lins, a $108 \mathrm{~km}$.

Os estudos do SEADE explicam que, desde o período da expansão cafeeira, na década de 1930, a infraestrutura viária de Bauru permitiu a ligação regional com a capital, o Porto de Santos e outras regiões do Estado e do país. A cidade de Bauru ocupa posição privilegiada para comércio, comunicações e transportes, em função de sua localização central e de constituir o maior entroncamento rodo-hidro-ferroviário da América Latina (IPEA, 2001). A necessidade da complementação do sistema viário em Bauru foi realizada com o transporte aéreo e a construção do aeroporto de Bauru e, mais recentemente, do Aeroporto Bauru/Arealva.

As atividades econômicas desenvolvidas na RA de Bauru estão ligadas ao setor terciário, que a consubstanciou como um importante centro regional. As atividades ligadas a indústrias somam uma pequena parcela da economia de Bauru. A indústria nunca se projetou além de seus contornos iniciais e o que caracterizou a região foi sua condição de pólo terciário, ao centralizar atividades comerciais, financeiras, de serviços e administrativas, cuja abrangência extrapolava seus limites (SEADE, 2008).

Todavia, embora as atividades econômicas não tenham projetado a cidade de Bauru como um importante centro catalizador de indústrias ${ }^{50}$, tal fato não impossibilitou o desenvolvimento econômico regional, que evolui baseado, predominantemente, na agropecuária. O município de Bauru é um centro de comercialização de animais (bovinos, equinos e suínos) e da produção de cana-de-açúcar, que representa seu o principal cultivo que, ultimamente tem passado por um processo de mecanização.

\footnotetext{
${ }^{50}$ Desde o início, a indústria regional da RA de Bauru esteve calcada em atividades de beneficiamento agrícola ou na produção de bens finais demandados pelo processo de urbanização (SEADE, 2008).
} 
Ao tratar do sistema de transportes em Bauru e, em especial, do aeroviário, observa-se que a construção de um segundo aeroporto confirmou-se diante da necessidade de uma melhor e mais adequada infraestrutura de transporte. De acordo com as pesquisas do IPEA (2001), que traça o perfil da caracterização da rede urbana regional do Brasil, destaca-se que, além de possuir diversas ligações com a capital paulista por meio dos mais diversos modais, Bauru é, ainda, rota aeroviária do Estado e, em razão de sua localização estratégica central, destaca-se como um importante nó da rede urbana paulista, uma vez que permite conexões e escalas com destinos para vários Estados da Federação.

Bauru possui dois aeroportos: o Aeroporto Estadual Moussa Nakhl Tobias (Bauru/Arealva) e Aeroporto Estadual de Bauru. Atualmente, apenas o Aeroporto Bauru/Arealva opera rotas com empresa aérea regular (Coletânea de mapas 4). A transferência das operações para o atual Bauru/Arealva se deu devido a sérias restrições operacionais e às reduzidas dimensões da pista do antigo aeroporto e, também, devido ao fato de o local estar envolto pela malha urbana, o que comprometia as condições de segurança das aeronaves e dos passageiros. No entanto, essas mudanças não fomentaram o aumento da demanda de passageiros.

O Aeroporto de Bauru encontra-se na categoria 3, segundo a ANAC. Já o Bauru/Arealva ainda não foi classificado segundo as categorias especificadas pela agência, devido à ausência de equipamentos que definam a categorização dos aeroportos. O Aeroporto funciona no que é designado como $\mathrm{H} 24$, nomenclatura utilizada na aviação que significa funcionar vinte quatro horas por dia, sendo que suas operações de pousos e decolagens são controladas pela INFRAERO.

Apesar de não constituir um importante $h u b$ para a aviação regional paulista, o Aeroporto de Bauru/Arealva é subaproveitado pelo DAESP e pelas empresas aéreas. Bauru/Arealva ainda não possui o dinamismo que lhe confere, já que opera apenas visualmente e não com instrumentos, que, atualmente, estão sendo instalados, como os equipamentos de auxílio à navegação aérea.

Bauru/Arealva possui, hoje, um dos melhores sítios aeroportuários do Estado de São Paulo e dispõe de ampla área operacional. Abriga apenas uma companhia aérea - a Pantanal Linhas Aéreas - que opera linhas para São Paulo e ainda é ponto de conexão para algumas cidades do interior do Estado, como nos voos com destino ou origem em Araçatuba e Marília. No ano de 2009, a companhia Passaredo passou a operar voos com escalas em Bauru/Arealva, mas o aeroporto, assim como o de Marília, não constitui base territorial de 
operações aéreas da empresa, sendo que ambas são pontos de escalas nas ligações entre Presidente Prudente e São Paulo, conforme Quadro 4.

Quadro 4 - Programação de voos do Aeroporto de Bauru/Arealva - 2008

\begin{tabular}{|c|c|c|c|c|}
\hline \multicolumn{5}{|c|}{ Decolagens } \\
\hline Empresa & Voos diários & Origem & Escala & Destino \\
\hline Pantanal & 4 & Bauru/Arealva & Não & São Paulo \\
\hline Pantanal & 1 & Bauru/Arealva & Não & Araçatuba \\
\hline Pantanal & 1 & Bauru/Arealva & Não & Marília \\
\hline Passaredo & 3 & Pres. Prudente & $\begin{array}{c}\text { Bauru/Arealva } \\
\text { e Marília }\end{array}$ & São Paulo \\
\hline Passaredo & 2 & Bauru/Arealva & Não & São Paulo \\
\hline \multicolumn{5}{|c|}{ Pousos } \\
\hline Empresa & Voos diários & Origem & Escala & Destino \\
\hline Pantanal & 4 & São Paulo & Não & Bauru/Arealva \\
\hline Pantanal & 1 & Araçatuba & Não & Bauru/Arealva \\
\hline Pantanal & 1 & Marília & Não & Bauru/Arealva \\
\hline Passaredo & 3 & São Paulo & $\begin{array}{c}\text { Bauru/Arealva } \\
\text { e Marília }\end{array}$ & Pres. Prudente \\
\hline Passaredo & 2 & São Paulo & Não & Bauru/Arealva \\
\hline
\end{tabular}

Fonte: Trabalho de campo, 2008

Org.: Camilo Pereira, 2009

Foto 10 - Aeroporto de Bauru/Arealva - 2006

\section{Aeroporto de Bauru-Arealva}

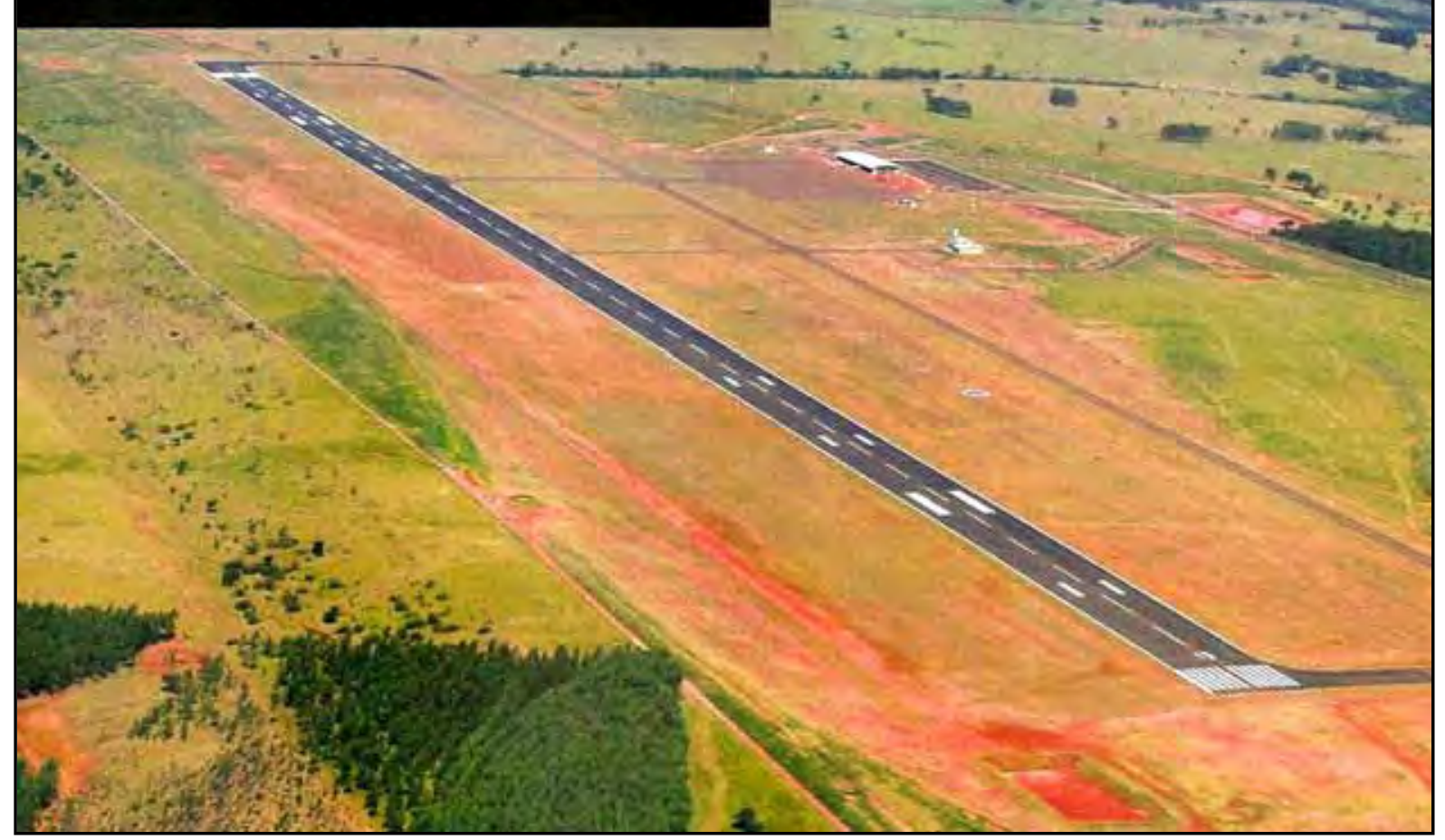

Fonte: Revista Aeroportos do DAESP, 2006 
Embora ainda não possua condições operacionais que possam estimular seu crescimento, o Aeroporto de Bauru/Arealva tem demonstrado um aumento no número de passageiros transportados pelo modal aéreo, sobretudo em 2007, ano em que foram deslocados 40.372 passageiros. Em comparação ao ano de 2006, observa-se um crescimento de $57,1 \%$.

O desenvolvimento econômico do Estado de São Paulo demonstra que Bauru tem registrado um crescimento econômico regional condizente com o aumento do tráfego aéreo, fator que justifica a construção de um novo aeroporto. A recente construção do Aeroporto de Bauru/Arealva contribuiu para o desenvolvimento do modal aéreo na cidade, substituindo, assim, os voos regulares do antigo Aeroporto de Bauru, que apresentava condições precárias para o transporte aéreo regular de passageiros.

Nota-se que a principal rota aérea com origem em Bauru é para o Aeroporto de Congonhas, que apresentou um montante de 295.213 passageiros transportados entre os anos correspondentes da pesquisa. A segunda principal ligação é com o Aeroporto de Araçatuba, devido ao fato de Bauru ser escala de voos para Araçatuba e desta para São Paulo. Observase, portanto, que as ligações aéreas com destinos para Araçatuba não correspondem à amplificação das interações espaciais entre as duas cidades, uma vez que Bauru constitui apenas uma conexão e/ou escala para Araçatuba, pois os passageiros tinham como origem a cidade de São Paulo e destino a cidade de Araçatuba.

Essa estatística é compreensível, já que Bauru está centralmente localizada no Estado de São Paulo, o que facilita a escala de voos com destinos distintos, função, essa, ainda pouco explorada pela aviação comercial regional no Estado de São Paulo. Em geral, observa-se um crescimento nas operações de passageiros no Aeroporto de Bauru/Arealva equivalente a $221,5 \%$. 


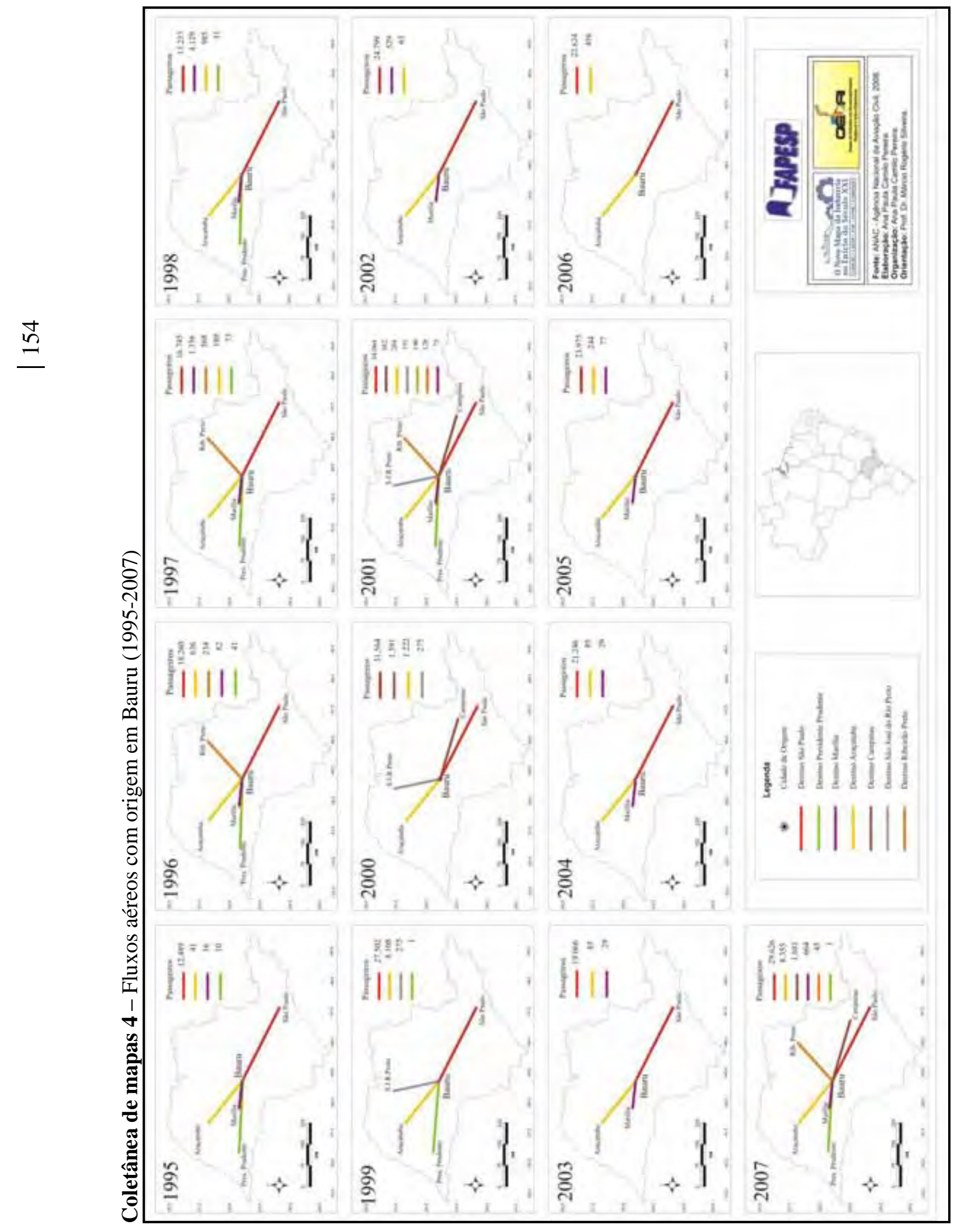




\subsubsection{Marília}

O município de Marília faz parte da $11^{\mathrm{a}}$ Região Administrativa do Estado, polarizando ampla área do Sudoeste do Estado de São Paulo, com articulações que se estendem a vários municípios do Norte do Paraná (IPEA, 2001).

Diferente das demais cidades especificadas, Marília não se desenvolveu a partir do ferroviarismo, seu desenvolvimento e interligação com a capital paulista e outros centros urbanos se deu mediante a utilização e conformação de uma extensa malha rodoviária que circunda a cidade.

Embora seja um importante centro regional, seu grau de polarização não é tão acentuado como ocorre em outros pólos de regiões administrativas, visto que as atividades econômicas distribuem-se mais uniformemente entre os demais sub-centros regionais como, por exemplo, em Ourinhos, Assis e Tupã. Estes apresentam boa qualidade de vida e expressiva produção agrícola, polarizando vários municípios vizinhos (SEADE, 2008).

Diante do perfil regional econômico de sua região de influência, nota-se que há a predominância de atividades voltadas para a agropecuária. A região é destaque na produção agrícola. Segundo o SEADE (2008), a RA de Marília é tradicional pela cultura de café. No entanto, vem diversificando sua produção e, com isso, mantém uma conexão produtiva no setor de soja, por intermédio dos municípios localizados mais ao Sul.

Contudo, a cidade de Marília manifesta uma contradição com sua região de influência, ou seja, desenvolveram-se na cidade atividades industriais baseadas no capital local. Assim, Marília obteve destaque na produção de alimentos ${ }^{51}$, esquadrias metálicas e máquinas agrícolas. Para Mourão (2009), o processo de industrialização de Marília seguiu, primeiramente, uma base produtiva local que, posteriormente, transformou-se em pequenas indústrias, acelerando o ritmo industrial da cidade e abrindo perspectivas de atração e desenvolvimento de novos ramos.

Contudo, o desenvolvimento do transporte aéreo em Marília tem prestígio na aviação comercial, sobretudo devido ao fato da companhia TAM ter sido fundada na cidade e, atualmente, ser uma das principais companhias aéreas nacionais.

Embora funcione 24 horas, o aeroporto apresenta baixo potencial de tráfego aéreo de passageiros/dia. O aeroporto inclui-se na categoria 3, suas operações são orientadas pela

\footnotetext{
${ }^{51}$ Cabe destacar que Marília concentra uma importante aglomeração de indústria de transformação do ramo de alimentação.
} 
INFRAERO. As condições gerais de infraestrutura encontram-se precárias, principalmente o terminal de passageiros e as salas de embarque e desembarque ${ }^{52}$.

O Aeroporto Estadual Frank Miloye Milenkowichi abriga apenas a companhia aérea Pantanal Linhas Aéreas, mas é ponto de escala da empresa Passaredo, que oferece voos com escala para Presidente Prudente, Bauru/Arealva e São Paulo.

Quadro 5 - Programação de voos do Aeroporto de Marília - 2008

\begin{tabular}{|c|c|c|c|c|}
\hline \multicolumn{5}{|c|}{ Decolagens } \\
\hline Empresa & Voos diários & Origem & Escala & Destino \\
\hline Pantanal & 3 & Marília & Não & São Paulo \\
\hline Pantanal & 1 & Marília & Bauru/Arealva & São Paulo \\
\hline Passaredo & 4 & Pres. Prudente & $\begin{array}{c}\text { Marília e } \\
\text { Bauru/Arealva }\end{array}$ & São Paulo \\
\hline Empresa & Voos diários & Origem & Escala & Destino \\
\hline Pantanal & 3 & São Paulo & Não & Marília \\
\hline Pantanal & 1 & São Paulo & Bauru/Arealva & Marília \\
\hline Passaredo & 4 & São Paulo & $\begin{array}{c}\text { Marília e } \\
\text { Bauru/Arealva }\end{array}$ & Pres. Prudente \\
\hline
\end{tabular}

Fonte: Trabalho de campo, 2008

Org.: Camilo Pereira, 2009

${ }^{52}$ Em entrevista realizada no DAESP, confirmam-se informações de que o Aeroporto de Marília pode ser fechado, pelo fato de sua instalação ser relativamente pequena e estar localizado próximo às aéreas residenciais e comerciais da cidade, o que dificulta sua ampliação e o interesse por demais companhias aéreas. No entanto, em entrevista realizada em 24 de setembro de 2008, essa informação foi negada; alegou-se que o aeroporto é uma importante rota de destino e de conexão para o transporte aéreo regional paulista. $\mathrm{O}$ que se observa é um desencontro de informações, que não são pormenorizadas nas entrevistas, devido ao fato de os próprios entrevistados oporem-se a tal confirmação. 
Foto 11 - Aeroporto de Marília - 2006

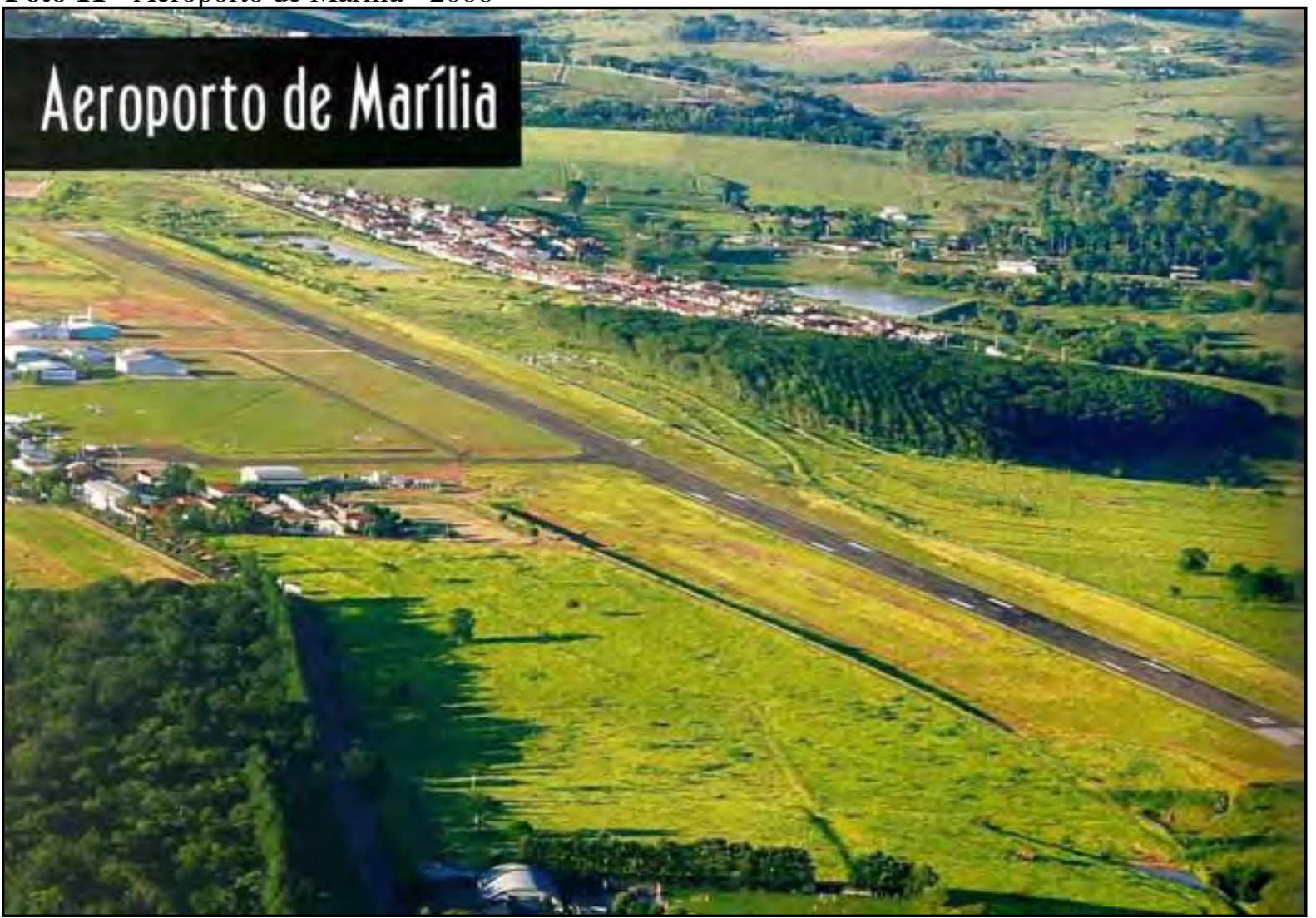

Fonte: Revista Aeroportos do DAESP, 2006

Marília tem apresentado uma baixa demanda pelo modal aéreo quando comparada às demais cidades analisadas no Estado. Isso é explicado pelo fato de Marília estar localizada próxima a duas importantes cidades que possuem aeroportos que operam voos regulares e que apresentam uma melhor infraestrutura aeroviária - Bauru e Presidente Prudente.

Cabe destacar que, assim como Araçatuba e Bauru, Marília conta apenas com uma empresa aérea operando voos regulares, e esta está na iminência de paralisar suas operações. As operações da empresa aérea Pantanal têm conferido aos aeroportos uma situação de pouca demanda em relação à oferta, o que é explicado pelo número de passageiros transportados. É importante destacar que as entrevistas realizadas revelaram a falta de confiança dos passageiros e dos administradores dos aeroportos, ora pela gestão da empresa, ora pela inadequação da Pantanal às regras e normas estabelecidas, tais como as relativas aos atrasos nos horários de voos.

Marília apresenta o menor número de passageiros transportados para a cidade de São Paulo, mesmo esta sendo sua principal ligação aérea. Entre os anos de 1995 a 2007, foram transportados para o Aeroporto de Congonhas 130.669 passageiros. 
As interações espaciais verificadas demonstram que Presidente Prudente é uma rota constante nas operações aéreas com o Aeroporto de Marília, por ser este o destino final de ligações aéreas com origem na cidade de São Paulo. Assim, temos que na relação temporal deste trabalho, foram embarcados 17.089 passageiros da cidade de Marília para a cidade de Presidente Prudente. Consideramos, nesse ínterim, que há uma integração territorial entre estas cidades, em razão da proximidade entre ambas, mas também à complementação regional, que é, igualmente, percebida entre as cidades de Marília e Bauru, embora estas consubstanciem uma situação de complementação diferente da de Presidente Prudente (Coletânea de mapas 5).

Nesse sentido, nota-se que Bauru é outra importante ligação aérea com origem na cidade de Marília. No período correspondente, 9.614 passageiros utilizaram o modal aéreo com destino à cidade de Bauru. O Aeroporto de Marília opera quatro voos diários para São Paulo, sendo um com escala em Bauru. Isso se deve, também, ao fato de que embarcar mais passageiros em Bauru com destino a São Paulo é mais rentável para a empresa aérea que opera a rota descrita.

Entre anos de 1997 a 2000, houve uma queda considerável do transporte aéreo em Marília. Observa-se que no ano de 2000 apenas 1.417 passageiros embarcaram no Aeroporto da cidade, declínio resultante das condições operacionais da empresa Pantanal, e também devido os preços das passagens cobradas pela mesma. A diminuição de passageiros transportados com origem em Marília sofreu uma queda na ordem de 92,2\%. 


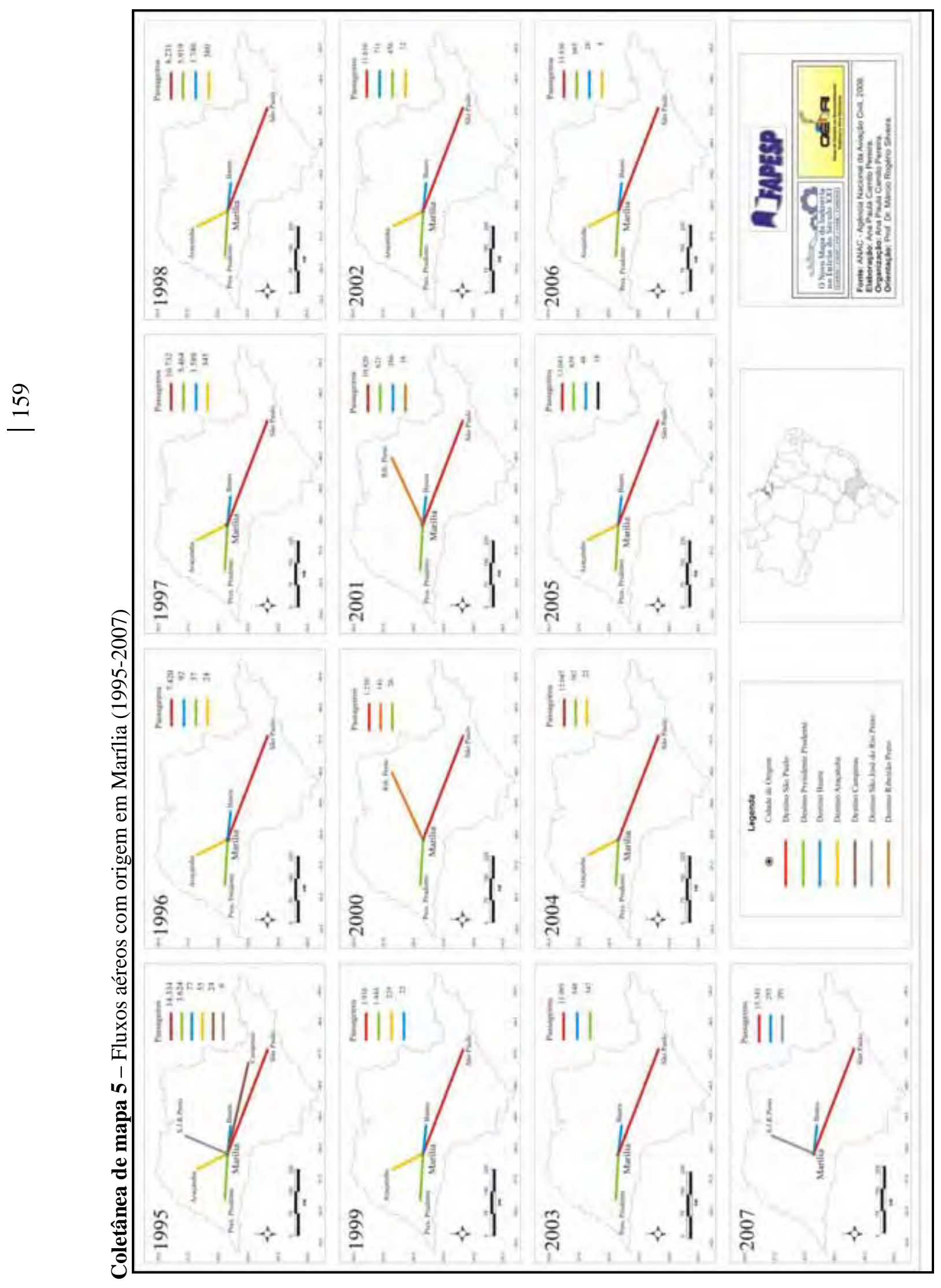




\subsubsection{Presidente Prudente}

Presidente Prudente está localizada no extremo Oeste do Estado de São Paulo e pertence a $10^{\mathrm{a}}$ Região Administrativa de Estado. A RA de Presidente Prudente conta com 53 municípios. A cidade possui uma localização geográfica estratégica, no entroncamento entre os Estados de Mato Grosso do Sul, São Paulo e Paraná, o que proporciona um raio de influência que ultrapassa os limites do Estado de São Paulo, atraindo passageiros do Norte do Estado do Paraná e do Sul de Mato Grosso do Sul.

O município apresenta grande concentração de atividades econômicas ligadas ao setor primário. As grandes propriedades destinadas à pecuária bovina extensiva prevalecem na região. As atividades industriais vinculam-se ao setor primário, isto é, os segmentos relacionados à produção de bens de consumo não-duráveis complementam a atividade pecuária, como, por exemplo, os frigoríficos e a produção alimentícia de origem agrícola (IPEA, 2001).

Sua constituição histórica e seu desenvolvimento econômico regional sempre estiveram relacionados a tais atividades.

$\mathrm{Na}$ década de 20 , a cultura cafeeira foi fortemente impulsionada pela implantação da Estrada de Ferro Sorocabana, que constituiu elemento decisivo para a ocupação regional e a formação da rede de cidades. Nas décadas de 1970 e 1980, ao contrário do que aconteceu em algumas regiões administrativas, onde o processo de descentralização industrial teve efeitos expressivos, a indústria regional, fortemente centrada na transformação agropecuária, teve uma participação reduzida no conjunto do setor secundário paulista. Nos anos de 1970, a região prudentina firmou-se como a área do Estado com o maior rebanho de bovinos de corte. A expansão da pecuária, o recuo das áreas de lavoura e a modernização da agropecuária, junto com as transformações na indústria, interagiram sobre o movimento populacional e a urbanização, refletindo na diminuição do segmento rural e no crescimento da população urbana elevando o contingente ligado ao setor de comércio e serviços (SEADE, 2008, p. 3).

A concretização do Aeroporto de Presidente Prudente veio confirmar o crescimento urbano regional e trouxe para a região uma maior e melhor conexão com a capital e outros centros urbanos do país.

O Aeroporto de Presidente Prudente classifica-se na categoria 3; seu funcionamento é designado em H24, sendo a parte relativa à navegação aérea controlada pela INFRAERO. O aeroporto abriga três companhias aéreas realizando rotas: a Pantanal Linhas Aéreas, a Gol Linhas Aéreas Inteligentes e, mais recentemente, a Passaredo Linhas Aéreas. As rotas dessas empresas perfazem linhas semelhantes, sempre com acentuada malha de rotas para a capital paulista. 
A linha executada pela Gol, para a cidade de Cuiabá, tem atraído muitos passageiros e tem sido considerada a principal expansão da empresa na cidade de Presidente Prudente. Alguns dados especulativos informam que, no ano de 2010, entrará no mercado aéreo de Presidente Prudente, a mais nova empresa aérea do país: a AZUL Linhas Aéreas Brasileiras.

Após a entrada da Gol Linhas Aéreas Inteligentes em Presidente Prudente, novos cenários foram traçados para aviação comercial regional. A cidade passou a comportar a terceira maior movimentação de passageiros no Estado, em comparação com os demais aeroportos de voos regulares e controlados pelo DAESP.

A empresa trouxe novas perspectivas de desenvolvimento para o setor aéreo na cidade, principalmente em relação à concorrência com a empresa Pantanal. A entrada da companhia aumentou a demanda de passageiros pelo modal aéreo, o que, consequentemente, impulsionou reformas e melhorias nas condições de infraestrutura, como no saguão, nos terminais de embarque e desembarque, na fiscalização e, sobretudo, no recapeamento dos sistemas de pistas de pátio e de acesso. A recente entrada da Passaredo no mercado prudentino é consequência dos resultados positivos que o aeroporto de Presidente Prudente tem apresentado, o que tem atraído diversas empresas.

Atualmente, as empresas destinam e recebem voos de São Paulo, embora a Gol possua uma arrecadação maior do que a Pantanal. Uma grande parcela dos passageiros prefere a Gol, por ser esta uma empresa que possui aeronaves modernas e mais velozes e, também, em razão das condições que a empresa tem oferecido, como valores das passagens aéreas e a pontualidade nos horários, o que desfavoreceu a empresa concorrente (Pantanal) que, no presente momento, encontra-se em processo de concordata junto ao Governo Federal. No entanto, a Passaredo tem reorganizado a demanda em função de sua oferta. A malha de voos da empresa tem distribuído os passageiros entre as empresas.

A três companhias, Gol Linhas Aéreas Inteligentes, Passaredo Linhas Aéreas e Pantanal Linhas Aéreas, operam voos diários para a capital paulista. A Gol oferece, ainda, um voo diário de escala em Presidente Prudente para Cuiabá e uma escala de Cuiabá para São Paulo (Quadro 6).

Quadro 6- Programação de voos do Aeroporto de Presidente Prudente - 2008

\begin{tabular}{|c|c|c|c|c|}
\hline \multicolumn{5}{|c|}{ Decolagens } \\
\hline Empresa & Voos diários & Origem & Escalas & Destino \\
\hline Pantanal & 2 & Pres. Prudente & Marília & São Paulo \\
\hline Gol & 2 & Pres. Prudente & Não & São Paulo \\
\hline
\end{tabular}




\begin{tabular}{|c|c|c|c|c|}
\hline Gol & 1 & São Paulo & $\begin{array}{c}\text { Presidente } \\
\text { Prudente }\end{array}$ & Cuiabá \\
\hline Passaredo & 1 & Pres. Prudente & $\begin{array}{c}\text { Bauru/Arealva } \\
\text { e Marília }\end{array}$ & São Paulo \\
\hline Passaredo & 1 & Pres. Prudente & Não & São Paulo \\
\hline \multicolumn{5}{|c|}{ Pousos } \\
\hline Empresa & Voos diários & Origem & Escalas & Destino \\
\hline Pantanal & 2 & São Paulo & Marília & Pres. Prudente \\
\hline Gol & 2 & São Paulo & Não & Pres. Prudente \\
\hline Gol & 1 & Cuiabá & Pres. Prudente & São Paulo \\
\hline Passaredo & 1 & São Paulo & $\begin{array}{c}\text { Bauru/Arealva } \\
\text { e Marília }\end{array}$ & Pres. Prudente \\
\hline Passaredo & 1 & São Paulo & Não & Pres. Prudente \\
\hline
\end{tabular}

Fonte: Trabalho de campo, 2008

Org.: Camilo Pereira, 2009

Foto 12 - Aeroporto de Presidente Prudente - 2006

\section{Aeroporto de Presidente Prudente}

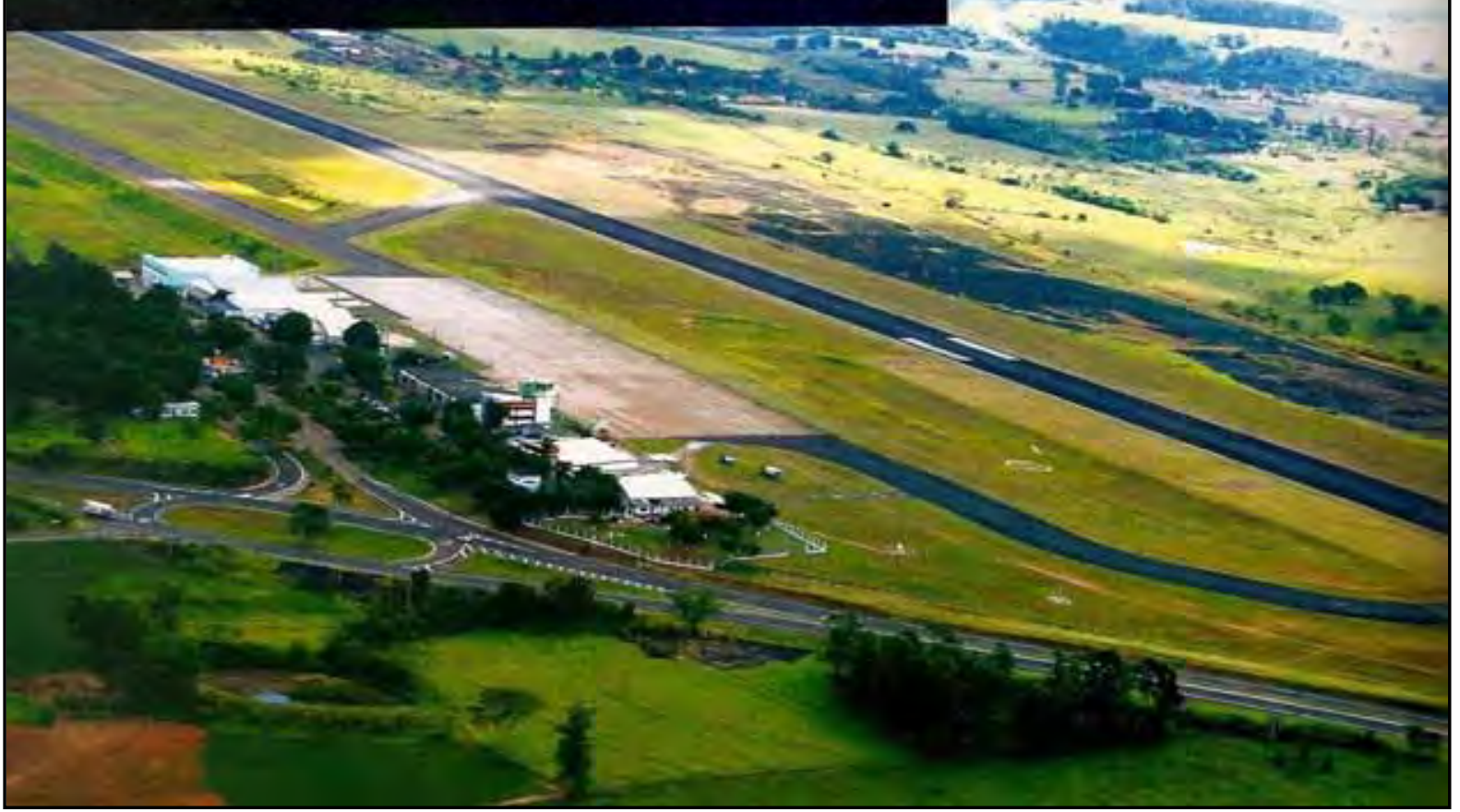

Fonte: Revista Aeroportos do DAESP, 2006

O Aeroporto de Presidente Prudente é de essencial importância para o transporte aéreo regional do Oeste Paulista, devido, sobretudo, à situação geográfica de Presidente Prudente. Nesse sentido, a cidade apresenta uma demanda considerável pelo modal aéreo, sendo sua principal rota aquela com destino à cidade de São Paulo. O aeroporto é o principal fixo para a expansão das linhas aéreas regionais no Estado de São Paulo, uma vez que Ribeirão Preto (principal hub secundário do Estado) já se encontra saturado, devido a 
quantidade de empresas que operam no aeroporto, o número de operações aéreas e, principalmente, em razão da infraestrutura técnica do aeroporto (saguão, guichês, esteiras de bagagem, sala de embarque etc.) não comportam mais o número de passageiros que utilizam o terminal, enfatizando mais uma vez a necessidade de investimentos.

Quantitativamente, o Aeroporto de Presidente Prudente tem demonstrado oscilações no número de passageiros transportados. No ano de 2007, Presidente Prudente apresentou um crescimento de $60 \%$ em relação ao ano anterior, por conta do aumento dos fluxos das empresas que operam no aeroporto.

É importante salientar que embarcaram em Presidente Prudente rumo ao Aeroporto de Congonhas 194.321 passageiros entre os anos de 1995 e 2007, como elucidado na Coletânea de mapas 6. Suas ligações secundárias perfazem percursos para a cidade de Marília, confirmando a integração territorial e a intensidade das interações espaciais, tendo sido transportados, nesse período, 13.704 passageiros.

Embora Presidente Prudente tenha demonstrado um acelerado ritmo em suas operações no último ano, observa-se que houve uma queda de 6,3\% no número de passageiros embarcados entre os anos de 1995 e 2007 . Essa queda pode ser explicada devido ao período em que a Pantanal Linhas Aéreas operou no Aeroporto de Presidente Prudente sem concorrência, o que estimulou a empresa a exceder os valores das passagens aéreas, provocando uma diminuição do número de passageiros que utilizavam o modal aéreo. Nota-se que, após a entrada da empresa Gol Linhas Aéreas Inteligentes no mercado de Presidente Prudente, no ano de 2007, houve um crescimento substancial do número de passageiros transportados. 


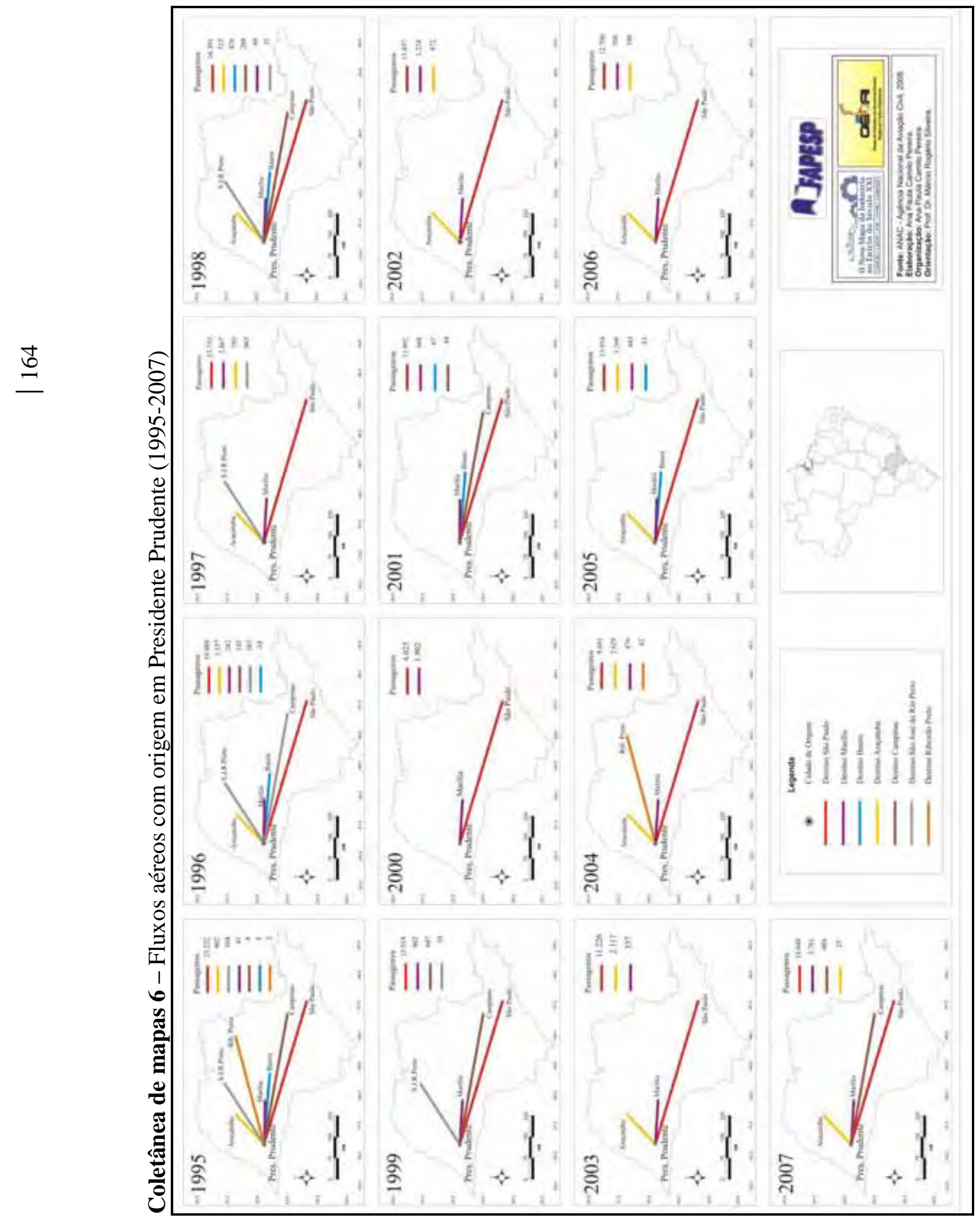




\subsubsection{Ribeirão Preto}

A cidade de Ribeirão Preto caracteriza-se pela sua importância na aviação comercial regional. Ribeirão Preto é o centro de uma vasta área que extrapola os limites do território paulista, exercendo influência em Estados como Minas Gerais e Goiás (IPEA, 2001).

A cidade é sede da $6^{\text {a }}$ Região Administrativa do Estado e também é acesso para o Estado de Minas Gerais. Sua RA conta com 25 municípios. O entorno de Ribeirão Preto constitui um elo de ligação e integração funcional que intensifica o grau de complementaridade e contiguidade da região com Ribeirão Preto, contribuindo para a maior demanda pelo modal aéreo.

A RA de Ribeirão Preto é servida por uma extensa rede viária, composta de rodovias, estradas vicinais, ferrovia e aeroporto, configurando-se como um importante entroncamento rodo-ferroviário (SEADE, 2008). A formação territorial da cidade e da região de Ribeirão Preto está ligada à cultura do café e à instalação da Companhia Mogiana de Estrada de Ferro, em 1973, que proporcionou seu desenvolvimento regional, implementando uma dinâmica territorial que a fez despontar economicamente no Estado de São Paulo.

Posterior à fase inicial de sua consolidação econômica no Estado de São Paulo, Ribeirão Preto encontrou na proliferação de usinas de cana-de-açúcar um desenvolvimento que imprimiu um novo ritmo de crescimento para a economia da cidade e de seu entorno. $\mathrm{O}$ Proálcool ampliou a rede viária regional e trouxe crescimento econômico, dinamizando, ainda mais, o setor terciário.

Por concentrar uma dinâmica estrutura de serviços, comércio, indústrias, entre outros, a inauguração do Aeroclube Leite Lopes, na cidade de Ribeirão Preto, em 2 de abril de 1939, trouxe maiores iniciativas de desenvolvimento local para a cidade. O Aeroclube teve projeção nacional e foi o pioneiro das elevadas iniciativas da aviação civil no Estado de São Paulo. Em 1982, foi inaugurado o Aeroporto Estadual Leite Lopes com ampliações e reformas que fizeram aumentar o tráfego, tornando-se o principal aeroporto regional do Estado de São Paulo (ARQUIVO HISTÓRICO DO AEROPORTO DE RIBEIRÃO PRETO, 2008).

O Aeroporto de Ribeiro Preto encontra-se na categoria 2; suas operações ocorrem em H24 e são orientadas pela INFRAERO. Apesar de ser o principal aeroporto regional do Estado de São Paulo, as condições gerais de infraestrutura do aeroporto são consideradas medianas devido à demanda ser maior do que a capacidade operacional aeroportuária. $\mathrm{O}$ terminal de passageiros do Aeroporto encontra-se em obras, com investimentos oriundos do Governo do Estado e licitados em 6,5 milhões de reais. No ano de 2006, a pista foi totalmente 
recapeada, tendo sido investidas verbas públicas do Estado que apresentam a soma de cerca de 28 milhões de reais.

De acordo com o SEADE (2008), a RA de Ribeirão Preto constitui um dos principais pólos econômicos regionais do Brasil, privilegiada pela sua situação geográfica, presença de universidades e centros de pesquisa, mão-de-obra qualificada, boa infraestrutura de transportes e comunicação e mercado consumidor dinâmico. Todos estes fatores, atrelados, beneficiam e são beneficiados pelo modal aéreo.

Segundo o DAESP, o aeroporto de Ribeirão Preto foi o que apresentou maior movimentação de passageiros no ano de 2007. O Aeroporto Estadual de Ribeirão possui três empresas do setor aéreo: a TAM Linhas Aéreas, a Passaredo Linhas Aéreas e a Trip/Total Linhas Aéreas ${ }^{53}$.

Os fluxos das empresas perfazem percursos semelhantes, sendo São Paulo a sua linha mais frequente (Quadro 7). No entanto, Ribeirão Preto possui linhas diversas para centros urbanos de outros Estados, como Minas Gerais, Paraná, Rio de Janeiro, Brasília entre outros. Esses percursos confirmam nossa argumentação de que há demanda de centros urbanos no interior do Estado de São Paulo para demais cidades de outros Estados, e esse fator pode favorecer o "descongestionamento" dos grandes aeroportos de São Paulo e, com isso, gerar desenvolvimento econômico e investimentos para o interior paulista. Ribeirão Preto possui um importante sistema aeroviário regional no Estado e é considerado o principal $h u b$ regional ou secundário do interior paulista, em razão de concentrar uma malha de voos diversificada e ser destino final de várias rotas aéreas.

Quadro 7 - Programação de voos do Aeroporto de Ribeirão Preto - 2008

\begin{tabular}{|c|c|c|c|c|}
\hline \multicolumn{5}{|c|}{ Decolagens } \\
\hline Empresa & Voos diários & Origem & Escalas & Destino \\
\hline TAM & 3 & Ribeirão Preto & Não & São Paulo \\
\hline Passaredo & 5 & Ribeirão Preto & Não & São Paulo \\
\hline Passaredo & 2 & Ribeirão Preto & Não & Curitiba \\
\hline Passaredo & 3 & Ribeirão Preto & Não & Brasília \\
\hline Passaredo & 2 & Ribeirão Preto & Não & Goiânia \\
\hline Passaredo & 2 & Ribeirão Preto & Não & Belo Horizonte \\
\hline Passaredo & 3 & Ribeirão Preto & Não & Rio de Janeiro \\
\hline Passaredo & 1 & Ribeirão Preto & Goiânia & Uberlândia \\
\hline
\end{tabular}

\footnotetext{
${ }^{53}$ Não opera voos regionais entre cidades do Estado de São Paulo.
} 


\begin{tabular}{|c|c|c|c|c|}
\hline Passaredo & 1 & Ribeirão Preto & Não & S. J. do R. Preto \\
\hline Trip/Total & 2 & Ribeirão Preto & Não & Uberlândia \\
\hline Trip/Total & 3 & Ribeirão Preto & Não & Rio de Janeiro \\
\hline \multicolumn{5}{|c|}{ Pousos } \\
\hline Empresa & Voos diários & Origem & Escalas & Destino \\
\hline TAM & 3 & São Paulo & Não & Ribeirão Preto \\
\hline Passaredo & 4 & São Paulo & Não & Ribeirão Preto \\
\hline Passaredo & 2 & Curitiba & Não & Ribeirão Preto \\
\hline Passaredo & 3 & Brasília & Não & Ribeirão Preto \\
\hline Passaredo & 2 & Goiânia & Não & Ribeirão Preto \\
\hline Passaredo & 2 & Belo Horizonte & Não & Ribeirão Preto \\
\hline Passaredo & 3 & Rio de Janeiro & Não & Ribeirão Preto \\
\hline Passaredo & 1 & S. J. do R. Preto & Não & Ribeirão Preto \\
\hline Trip/Total & 2 & Uberlândia & Não & Ribeirão Preto \\
\hline Trip/Total & 3 & Rio de Janeiro & Não & Ribeirão Preto \\
\hline
\end{tabular}

Fonte: Trabalho de campo, 2008

Org.: Camilo Pereira, 2009

Foto 13 - Aeroporto de Ribeirão Preto - 2006

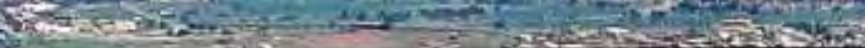 Aeroporto de Ribeirĩo Preto}

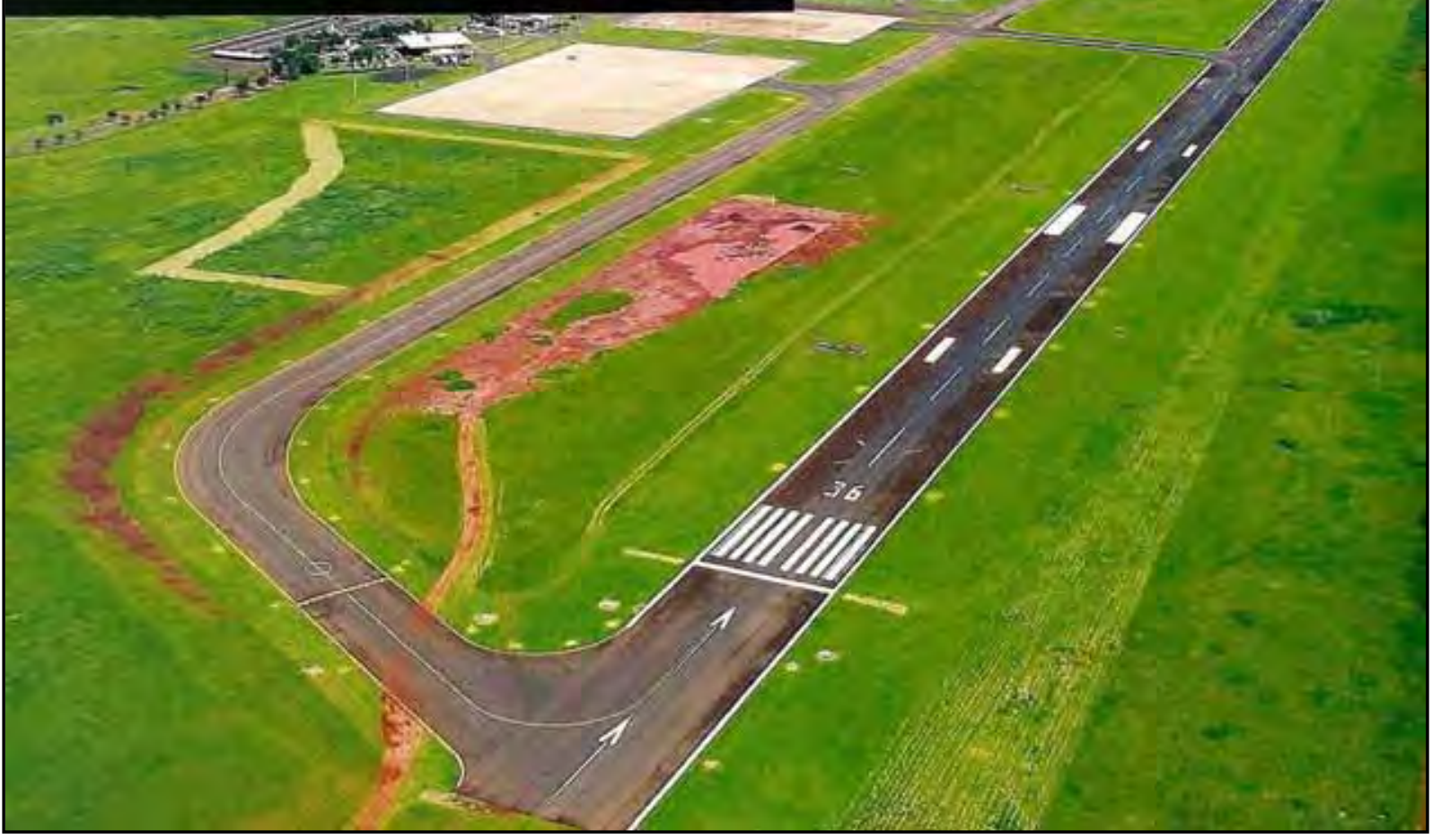

Fonte: Revista Aeroportos do DAESP, 2006 
Ribeirão Preto abriga o principal aeroporto regional do Estado de São Paulo. Perfaz rotas importantes do ponto de vista da quantidade de passageiros transportados e da frequência de voos. Possui como principal ligação a capital paulista, sendo suas principais ligações secundárias com as cidades de São José do Rio Preto e Campinas (Coletânea de mapas 7).

A quantidade de empresas que operam voos no Aeroporto de Ribeirão Preto justifica também o maior número de passageiros transportados. $\mathrm{O}$ ano de 2005 apresenta o maior número de passageiros que embarcaram na cidade de Ribeirão Preto, devido à quantidade e à expressividade das empresas que operavam no aeroporto naquele ano, como a TAM e a Gol. Observa-se que, neste mesmo ano, foram transportados 194.245 passageiros, e todos tinham como destino final a cidade de São Paulo.

Destaca-se, ainda, que as ligações aéreas da empresa Passaredo com destino à metrópole paulista são realizadas com o Aeroporto de Guarulhos/Cumbica. Desta forma, os passageiros que embarcam com a Passaredo geralmente fazem conexões e/ou escalas em Guarulhos para diversos destinos nacionais e internacionais. Os passageiros que têm como destino final a cidade de São Paulo optam pela TAM, que opera no aeroporto de Congonhas ${ }^{54}$.

Uma importante ligação aérea de Ribeirão Preto é com a cidade de São José do Rio Preto. As interações espaciais entre essas duas cidades são elucidados nos dados estatísticos que demonstram que as ligações aéreas perfazem um total de 28.449 passageiros transportados. Campinas também expressa uma importante ligação de Ribeirão Preto. Entre os anos de 1995 e 2007 foram transportados 24.995 passageiros. Tal fato se dá em razão de Campinas oferecer voos internacionais diversos.

Os anuários estatísticos mostram que entre o período analisado, foram transportados 1.391.806 passageiros para São Paulo. Na apuração percentual, Ribeirão Preto apresentou um crescimento de $114,4 \%$ no número de passageiros transportados.

\footnotetext{
${ }^{54}$ Há um acordo comercial entre essas duas empresas que se refere à distribuição de passageiro conforme seu destino final. Ver capítulo IV.
} 


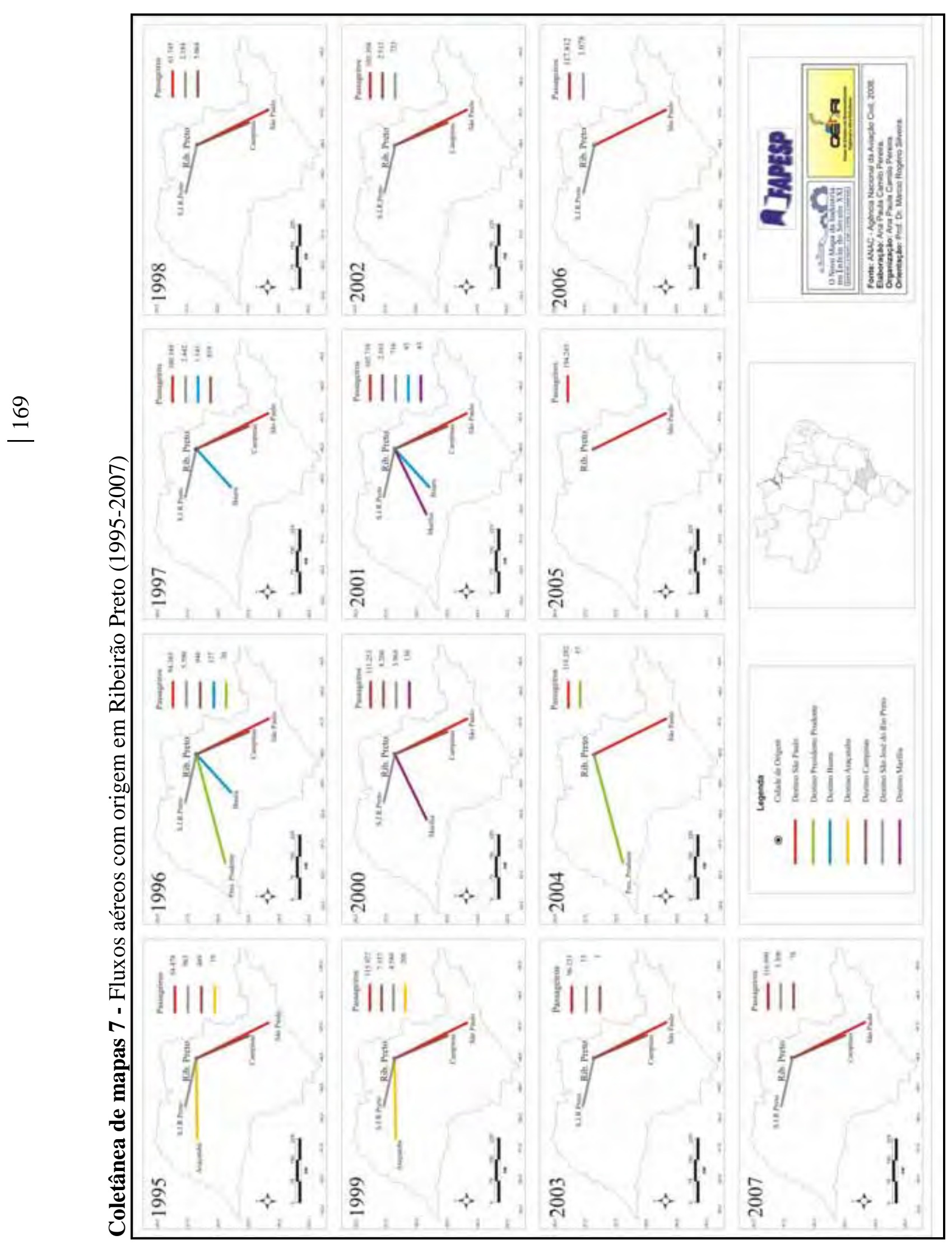




\subsubsection{São José do Rio Preto}

Sede da $8^{\text {a }}$ Região Adminstrativa do Estado, a cidade representa um pólo de atração para seu entorno, principalmente no setor aéreo. São José do Rio Preto está localizada a Noroeste do Estado, composta por 96 municípios, é uma capital regional que tem apresentado uma estrutura econômica dinâmica, além de se destacar pela sua capacidade de atrair investimentos ligados à atividade industrial (IPEA, 2001).

A cidade, bem como sua região, é bem servida pela malha viária regional, com importantes rodovias que interligam São José do Rio Preto às regiões do país, como a Transbrasiliana, a Washington Luís e a Assis Chateaubriand. Conta, ainda, com uma rede ferroviária que conecta a cidade e seu entorno à capital paulista (SEADE, 2008).

Caracterizada por constituir-se como um importante elo de escoamento de produtos agrícolas para a região Centro-Oeste do país, São José do Rio Preto teve sua formação territorial também ligada à constituição da ferrovia. De acordo com a caracterização regional realizada pelo SEADE (2008), com a chegada da Estrada de Ferro Araraquarense, em 1912, a cidade de São José do Rio Preto se transformou em pólo comercial, por onde passavam produtos agrícolas locais e as mercadorias vindas de São Paulo. Foi a partir dessa perspectiva de desenvolvimento que a região transformou-se, em meados da década de 1930, num grande centro agropecuário do Estado, integrado à dinâmica da economia paulista.

São José do Rio Preto compõe, atualmente, um importante centro comercial e de serviços, além de se caracterizar pelo seu potencial de atração industrial, exercendo-o sobre ampla área geográfica do Estado e de Estados vizinhos. A economia regional é baseada na produção agropecuária, integrada às atividades agroindustriais. (SEADE, 2008).

A construção do Aeroporto Professor Eribelto Manuel do Reino e sua inauguração, em 19 de abril de 1959, contribuíram para a confirmação do dinamismo econômico regional de São José do Rio Preto (CONJUNTURA ECONÔMICA SÃO JOSÉ DO RIO PRETO, 2003). Nesse sentido, o Aeroporto de São José do Rio Preto inclui-se na categoria 2 e suas operações de navegação aérea são controladas pela INFRAERO. O aeroporto apresenta-se como o $2^{\circ}$ maior em movimentação de passageiros do segmento regional do Estado de São Paulo.

O Aeroporto apresenta condições gerais infraestruturais médias. Nos últimos anos, obteve verbas do Governo do Estado e do PROFAA para a reforma do terminal e da pista. Sua infraestrutura, ainda que insuficiente, atrai empresas aéreas na operacionalização de voos. A Passaredo tem aumentado a frequência de voos com origem e destino em São José do Rio Preto. Além disso, a atuação da TAM tem demonstrado índices de constante crescimento. 
O Aeroporto de São José do Rio Preto possui duas empresas aéreas: a TAM Linhas Aéreas - com linhas para São Paulo e Cuiabá - e a Passaredo Linhas Aéreas - com rotas para Ribeirão Preto e Brasília, conforme Quadro 8.

Quadro 8 - Programação de voos do Aeroporto de São José do Rio Preto - 2008

\begin{tabular}{|c|c|c|c|c|}
\hline \multicolumn{5}{|c|}{ Decolagens } \\
\hline Empresa & Voos diários & \multicolumn{1}{c|}{ Origem } & Escala & Destino \\
\hline TAM & 3 & S. J. do R. Preto & Não & São Paulo \\
\hline TAM & 1 & S. J. do R. Preto & Não & Cuiabá \\
\hline Passaredo & 1 & S. J. do R. Preto & Não & Ribeirão Preto \\
\hline Passaredo & 1 & S. J. do R. Preto & Não & Brasília \\
\hline Passaredo & 2 & S. J. do R. Preto & Ribeirão Preto & Brasília \\
\hline \multicolumn{7}{|c|}{ Pousos } \\
\hline Empresa & Voos diários & Origem & Escala & Destino \\
\hline TAM & 3 & São Paulo & Não & S. J. do R. Preto \\
\hline TAM & 1 & Cuiabá & Não & S. J. do R. Preto \\
\hline Passaredo & 1 & Ribeirão Preto & Não & S. J. do R. Preto \\
\hline Passaredo & 1 & Brasília & Não & S. J. do R. Preto \\
\hline Passaredo & 1 & Brasília & Ribeirão Preto & S. J. do R. Preto \\
\hline
\end{tabular}

Fonte: Trabalho de campo, 2008

Org.: Camilo Pereira, 2009

Foto 14 - Aeroporto de São José do Rio Preto - 2006

\section{Aeroporto de São José do Rio Preto}

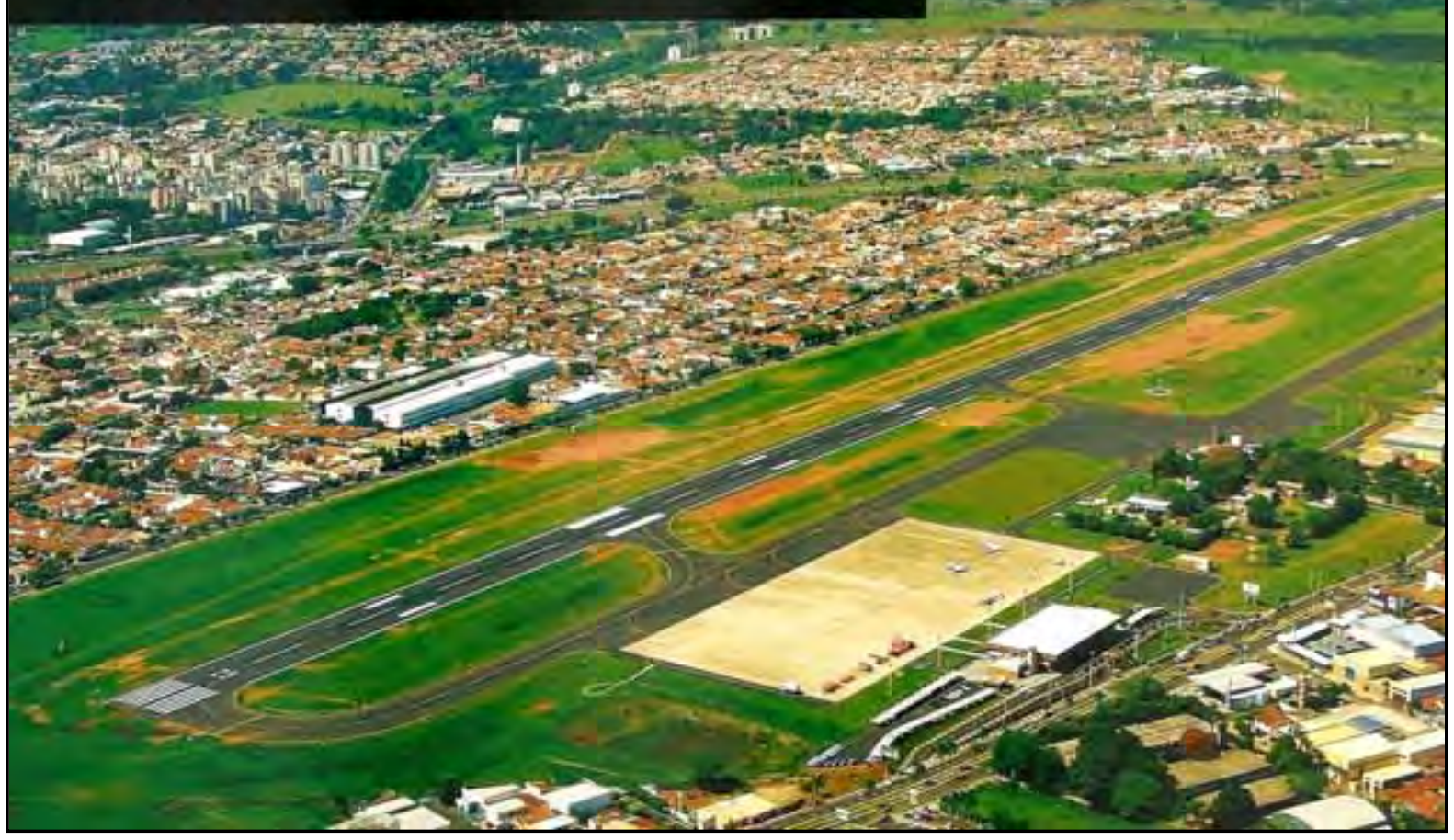

Fonte: Revista Aeroportos do DAESP, 2006 
O Aeroporto de São José do Rio Preto mantém seus fluxos com interligação para dois importantes e constantes destinos: São Paulo e Ribeirão Preto. Os dados estatísticos dos anuários demonstram que Campinas também recebe um fluxo considerável de passageiros com origem em São José do Rio Preto, demonstrado na Coletânea de mapas 8.

Entre os anos de 1995 e 2007, houve um crescimento considerável no transporte aéreo de passageiros no aeroporto da cidade. O ano de 2000 foi o menos significativo para São José do Rio Preto, em razão da transferência das operações do antigo aeroporto para o novo Aeroporto Estadual Prof. Eribelto Manoel Reino.

Os fluxos do aeroporto registram que embarcaram no Aeroporto de São José do Rio Preto 753.849 passageiros com destino à cidade de São Paulo, 26.508 com destino à Ribeirão Preto e 14.298 com destino à Campinas, o que registra a intensidade e o direcionamento de suas interações espaciais no Estado de São Paulo.

É importante enfatizar que, de acordo com as entrevistas realizadas nas cidades de São José do Rio Preto e Riberião Preto, há uma concorrência entre os aeroportos. Observa-se que a localização das duas cidades próximas, relativamente, para o setor aéreo, fomenta a competição entre os aeroportos das cidades. No entanto, Ribeirão Preto ainda tem um maior destaque no transporte aéreo, em razão da dinâmica econômica empreendida pela cidade, e, principalmente, devido ao fato da companhia Passaredo ter sua base territorial em Ribeirão Preto e ser a principal empresa aérea regional do Estado de São Paulo, o que permite uma maior exploração da aviação comercial regional pela cidade de Ribeirão Preto. 


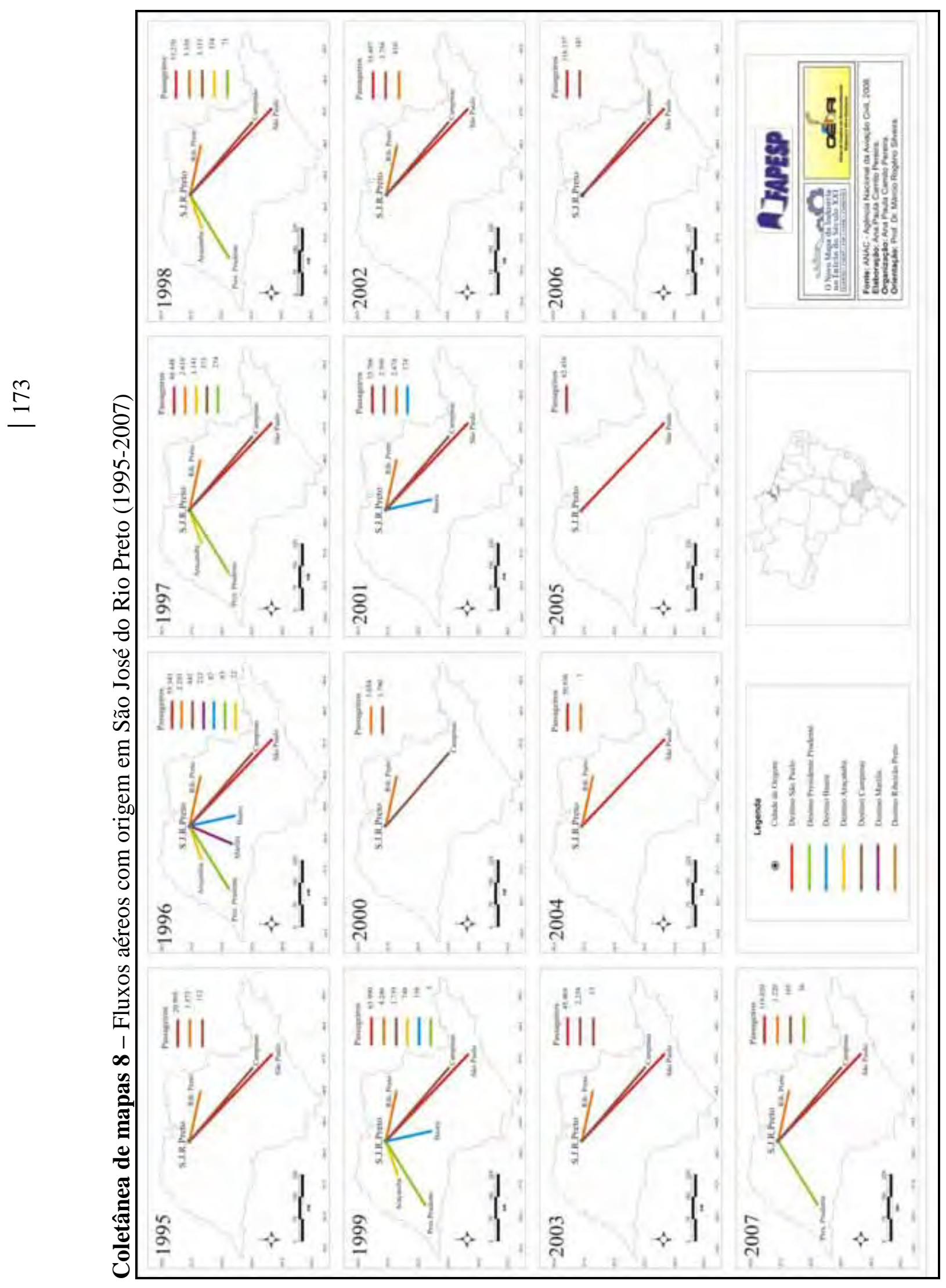




\subsubsection{São Paulo}

A conexão aérea com origem em São Paulo e com destino para o interior paulista merece uma apuração maior e mais detalhada de seus dados, devido à quantidade de passageiros transportados e à frequência das ligações aéreas com todas as cidades analisadas neste trabalho.

As redes geográficas expressam as interações espaciais e a organização tecnológica dos territórios e, assim, projeta a mobilidade territorial entre as cidades. Nesse sentido, ao observarmos os fluxos aéreos da capital paulista rumo ao seu interior, percebe-se que a capital mantém uma constância de interligação com todas as cidades, o que corresponde à intensidade das interações espaciais, embora essas ligações expressem níveis de contiguidade diferentes.

Nota-se que cidades como Ribeirão Preto recebem diariamente mais passageiros transportados pelo modal aéreo que os demais centros urbanos, tais como Araçatuba e Marília e, assim, mantêm um nível de interação espacial mais intenso no que tange ao transporte aéreo.

Os aeroportos localizados na cidade de São Paulo abarcam uma grande quantidade de conexões e/ou escala de voos que partem das e que chegam às cidades do interior paulista. Isso reflete de maneira muito clara o papel de complementaridade desses espaços em relação à capital metropolitana. No entanto, destacamos que muitos voos que fazem conexões e/ou escalas nos aeroportos paulistanos têm, muitas vezes, destinos diferentes e passam pela cidade de São Paulo apenas para cumprir a escala de voos, fator, este, que intensifica o congestionamento dos aeroportos centrais.

Os dados estatísticos mostram o crescimento no número de passageiros que utilizam os terminais aeroportuários da cidade de São Paulo por ser este um elo de entroncamento para as mais diversas localidades e por ser conexão e/ou escala de voos para outras cidades brasileiras e para outros países. No entanto, esse hub tem sido intensamente utilizado, o que provoca desajustes econômicos para o setor e fomenta a necessidade de novos locais de exploração do setor aéreo paulista.

No período compreendido de 1995 ao ano de 2007, o transporte aéreo na cidade de São Paulo cresceu 225,9\%, ${ }^{55}$ o que reflete sobremaneira a importância do setor aeroviário do Estado de São Paulo e dos aeroportos paulistanos.

\footnotetext{
${ }^{55}$ Esse percentual reflete o crescimento do número de passageiros transportados dos aeroportos de São Paulo para o interior do Estado.
} 
Embora o crescimento do setor aéreo regional no Estado de São Paulo tenha registrado um constante desenvolvimento e ampliação do número de pessoas que utilizam o modal para seus deslocamentos, ainda é evidente a maior utilização do modal rodoviário, em razão, principalmente, dos preços cobrados pelas passagens aéreas.

Todavia, a dinamicidade e a velocidade empreendidas pelo modal impõem-se na correlação entre o tempo percorrido no espaço quando comparado ao modal mais utilizado nas rotas entre o interior e a capital paulista, o rodoviário. A Tabela 11 exemplifica o tempo percorrido entre as cidades pesquisadas até a capital paulista pelos modais rodoviário e aéreo e seus respectivos valores.

Tabela 11 - Rotas com destino a São Paulo por transporte rodoviário e aeroviário ${ }^{56}$

\begin{tabular}{c|c|c|c|c|c}
\hline $\begin{array}{c}\text { Cidades } \\
\text { Médias }\end{array}$ & $\begin{array}{c}\text { Distância até } \\
\text { São Paulo } \\
(\mathbf{K m})\end{array}$ & $\begin{array}{c}\text { Transporte } \\
\text { Rodoviário }\end{array}$ & $\begin{array}{c}\text { Preço da } \\
\text { Passagem }\end{array}$ & $\begin{array}{c}\text { Transporte } \\
\text { Aéreo }\end{array}$ & $\begin{array}{c}\text { Preço da } \\
\text { passagem }\end{array}$ \\
\hline Araçatuba & $522 \mathrm{~km}$ & $08 \mathrm{~h} 00 \mathrm{~min}$ & $\begin{array}{c}\mathrm{R} \$ 71,55 \mathrm{a} \\
160,60\end{array}$ & $01 \mathrm{~h} 35 \mathrm{~min}$ & $\mathrm{R} \$ 279 \mathrm{a} 339$ \\
\hline Bauru & $326 \mathrm{~km}$ & $04 \mathrm{~h} 45 \mathrm{~min}$ & $\begin{array}{c}\mathrm{R} \$ 53,32 \mathrm{a} \\
57,00\end{array}$ & $00 \mathrm{~h} 55 \mathrm{~min}$ & $\mathrm{R} \$ 239 \mathrm{a} 299$ \\
\hline Marília & $438 \mathrm{~km}$ & $06 \mathrm{~h} 10 \mathrm{~min}$ & $\begin{array}{c}\mathrm{R} \$ 68,72 \mathrm{a} \\
70,65\end{array}$ & $01 \mathrm{~h} 05 \mathrm{~min}$ & $\mathrm{R} \$ 241 \mathrm{a} 299$ \\
\hline Pres. Prudente & $587 \mathrm{~km}$ & $07 \mathrm{~h} 50 \mathrm{~min}$ & $\begin{array}{c}\mathrm{R} \$ 94,95 \mathrm{a} \\
184,95\end{array}$ & $01 \mathrm{~h} 35 \mathrm{~min}$ & $\mathrm{R} \$ 119 \mathrm{a} 480$ \\
\hline Ribeirão Preto & $316 \mathrm{~km}$ & $04 \mathrm{~h} 30 \mathrm{~min}$ & $\begin{array}{c}\mathrm{R} \$ 55,50 \mathrm{a} \\
74,96\end{array}$ & $01 \mathrm{~h} 00 \mathrm{~min}$ & $\begin{array}{c}\mathrm{R} \$ 220 \mathrm{a} \\
539,50\end{array}$ \\
\hline $\begin{array}{c}\text { São J. do R. } \\
\text { Preto }\end{array}$ & $443 \mathrm{~km}$ & $05 \mathrm{~h} 15 \mathrm{~min}$ & $\mathrm{R} \$ 62 \mathrm{a} 99$ & $01 \mathrm{~h} 10 \mathrm{~min}$ & $\begin{array}{c}\mathrm{R} \$ 209 \mathrm{a} \\
699,50\end{array}$ \\
\hline
\end{tabular}

Fonte: Empresas do setor aéreo e rodoviário, 2008

Org.: Camilo Pereira, 2009

A comparação entre o tempo gasto pelos modais justifica a preferência dos usuários pelo transporte aéreo. Todavia, o maior número de cidades servidas pelo modal rodoviário e alguns aspectos desse setor, tais como o valor gasto em infraestrutura dos terminais rodoviários, o menor custo na aquisição de veículos (ônibus e equipamentos), o valor na produção dos mesmos, reflete no preço cobrado nas passagens rodoviárias. Soma-se a isso, ainda, a maior amplitude da malha rodoviária (apesar de seus problemas

\footnotetext{
${ }^{56}$ Informações obtidas em 08/10/2009.

${ }^{57}$ Cabe salientar que os valores cobrados pelas passagens aéreas são variáveis de acordo com a empresa que presta o serviço e com a classe do voo. Em períodos promocionais, isto é, períodos em que as empresas reduzem os preços das passagens aéreas, como tentativa de quebrar concorrência, encontra-se passagem com valores inferiores a $\mathrm{R} \$ 100,00$, de acordo com a origem e o destino do percurso.
} 
infraestruturais), o que têm ampliado a expressividade do modal rodoviário em detrimento ao aéreo.

Mesmo considerando a maior amplitude do setor rodoviário, em contraponto ao aéreo, observa-se que o principal agente de fomento à demanda e ao interesse do usuário por determinado modal consubstancia-se na operacionalização das empresas de transportes, no caso as empresas aéreas, e em suas ações estratégicas para atrair o consumidor.

A rede aeroviária paulista tem registrado crescimento do segmento regional, mesmo em decorrência do subaproveitamento das companhias no segmento. As entrevistas demonstraram que há capacidade de geração de tráfego em níveis diversos nas cidades analisadas e isso demanda um planejamento para que se aproveitem os complexos aeroportuários existentes no interior do Estado, pois estes são centros geradores de demanda. Todavia, o que ocorre é a má utilização da rede de fluxos aéreos.

As análises elaboradas a partir da apuração dos dados estatísticos e das entrevistas realizadas mostram a potencialidade do segmento aéreo regional, quando se observa o número de passageiros que se deslocam para as cidades paulistas (Coletânea de mapas 9). É possível observar que as cidades de Ribeirão Preto e São José do Rio Preto apresentaram, no ano de 2007, um crescimento considerável no número de passageiros que embarcaram e desembarcaram nos aeroportos das cidades supracitadas.

Nota-se que as cidades de Bauru, Marília e Presidente Prudente apresentam níveis de ampliação do número de passageiros semelhantes, sendo que a cidade Presidente Prudente demonstra um ligeiro acréscimo no número de passageiros no período analisado, principalmente no ano de 2007, por conta da entrada da empresa aérea Gol Linhas Aéreas Inteligentes.

Observa-se, ainda, que, no ano de 2002, todas as cidades apresentaram uma sensível diminuição do tráfego aéreo, em decorrência dos ataques terroristas ocorridos nos Estados Unidos no ano de 2001, que refletiram mundialmente no mercado da aviação comercial, principalmente na cidade São Paulo, que apresenta a maior queda, tanto em nível regional, como nacional e, sobretudo, internacional. 


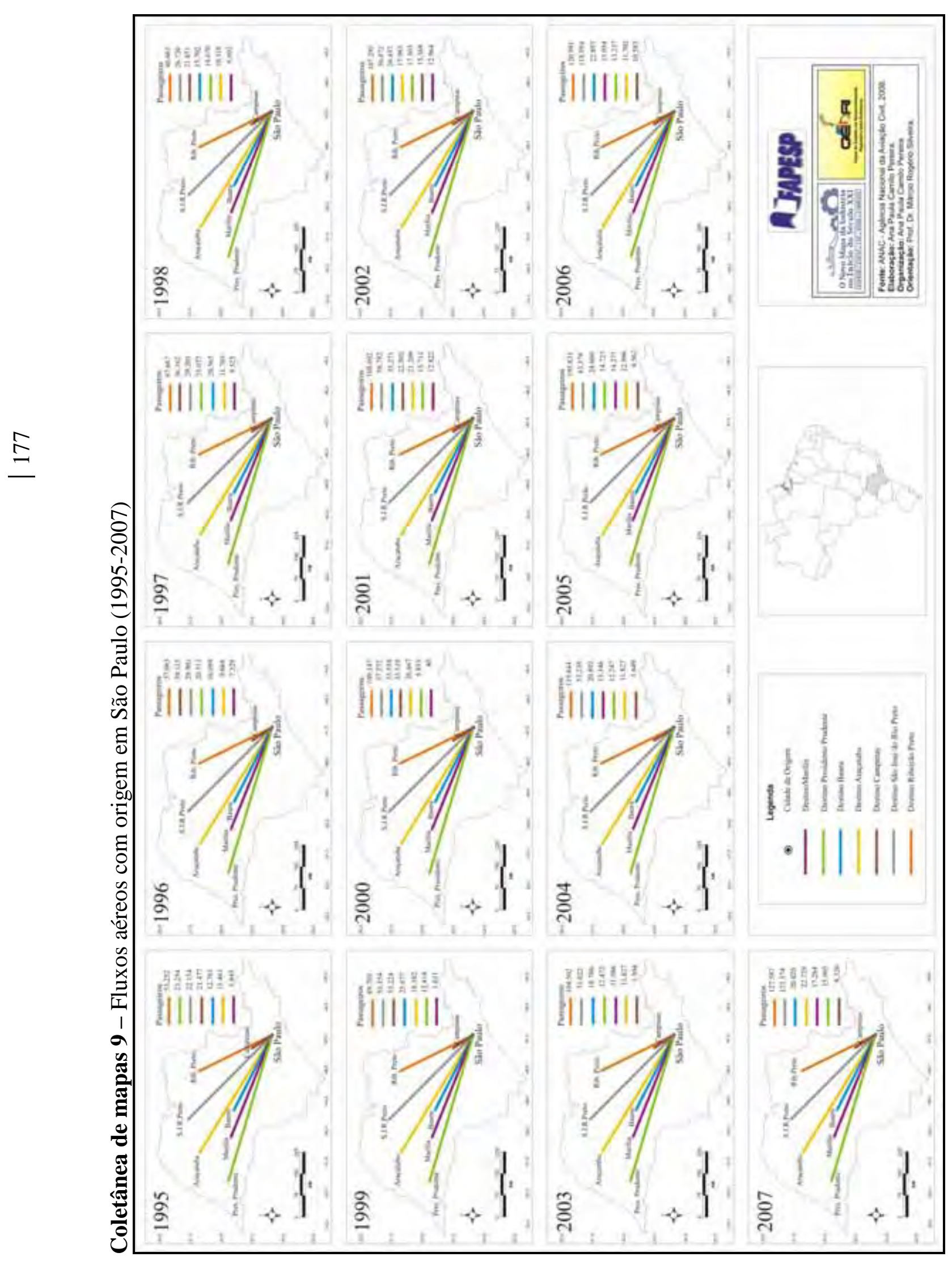


Os dados apresentados referem-se ao crescimento do número de passageiros transportados pelo transporte aéreo no segmento regional, isto é, entre as cidades pesquisadas e destas com a capital metropolitana. Desta forma, percebe-se que os níveis de ampliação do número de passageiros transportados revelam que há demanda e há oferta de transporte aéreo no Estado de São Paulo. A questão que se encerra concerne à inadequação da infraestrutura dos aeroportos, que não permitem voos mais "rasantes" e, consequentemente, um desenvolvimento econômico compatível com a expansão do número de passageiros que têm utilizado o setor aéreo regional.

Baseados nessa assertiva, bem como nas entrevistas realizadas, observamos que o grande fomento à aviação comercial regional consiste em voos que "não" fazem conexões e/ou escala em São Paulo, como os voos da empresa Passaredo Linhas Aéreas, que atua no mercado de Ribeirão Preto ${ }^{58}$. A empresa possui uma malha de voos diversificada, composta por linhas que operam voos diretos, como para Brasília, Belo Horizonte, Curitiba, Rio de Janeiro e Uberlândia. Esses fluxos, que atendem localidades com voos diretos, têm proporcionado à empresa o aumento do número de passageiros transportados, o que tem refletido na visibilidade da estruturação administrativa e técnica da empresa.

A partir dos fluxos das empresas aéreas que atuam nestas cidades, nota-se que os voos que decolam ou pousam nas mesmas são, geralmente, programados para ter conexões e/ou escala em São Paulo, principalmente, os voos com destinos estratégicos, isto é, aqueles que apresentam uma grande demanda de passageiros, como para os principais aeroportos nacionais (Brasília, Belo Horizonte, Campo Grande, Cuiabá, Curitiba, Florianópolis, Goiânia, Porto Alegre, Rio de Janeiro e Salvador).

A expressividade dos aeroportos de São Paulo é registrada pelas avaliações da ANAC, que os classificam na categoria 1, ou seja, são aeroportos que se apresentam tecnicamente mais especializados, tanto na organização de horários de voo, distribuição de slots para as empresas, como na manutenção infraestrutural dos fixos etc. Todavia, a partir das análises observadas no desenvolvimento da pesquisa, constatamos que os voos que, geralmente, têm destinos diferentes da capital paulista, não precisam necessariamente ter escala em São Paulo, intensificando o congestionamento dos aeroportos.

Novos hubs precisam ser criados no Estado de São Paulo, como forma de “desafogar" aeroportos de tráfego congestionado, projetando uma perspectiva de

\footnotetext{
58 Tal prerrogativa não se trata de apologia à companhia, mas sim de um planejamento que garante a operacionalidade do setor.
} 
desenvolvimento para demais centros urbanos que possuem potencial de tráfego subutilizado e, assim, proporcionar uma reorganização territorial condizente com o transporte aéreo.

O transporte aéreo enfrenta, atualmente, uma crise econômica que repercute principalmente no Estado de São Paulo, por ser responsável pelo maior número de passageiros transportados no país. A necessidade de planejamento para o setor de transporte aéreo torna-se crucial para o seu crescimento, inclusive em âmbito regional, como forma de promover a fluidez territorial a partir das redes e dos fixos instalados nas cidades.

A mecanização das atividades resultantes do tempo de execução no espaço é movida pelo que Santos (2002) define como "frenesi da velocidade". Se a circulação é o vetor fundamental da sociedade atual e se a velocidade constitui um ramo estratégico para o desenvolvimento econômico paulista, a necessidade de equilibrar os fatores é primordial. Para isso, a infraestrutura dos fixos e o planejamento tornam-se questões fundamentais.

O desenvolvimento do transporte aéreo regional - reflexo das redes que conectam os territórios, inclusive aqueles descontínuos espacialmente - afirma-se como uma forma imediata de fluidez territorial. Nesse sentido, é essencial um sistema bem articulado do transporte aéreo, que se consubstancie pelas suas principais características, isto é, a supressão do espaço pelo tempo e a integração territorial. Tal fato é verificado na Coletânea de mapas 10, no qual está expresso o número de passageiros que utilizaram o modal aéreo em seus deslocamentos no período analisado. Com isso enfatizamos o potencial aeroviário do Estado de São Paulo. 


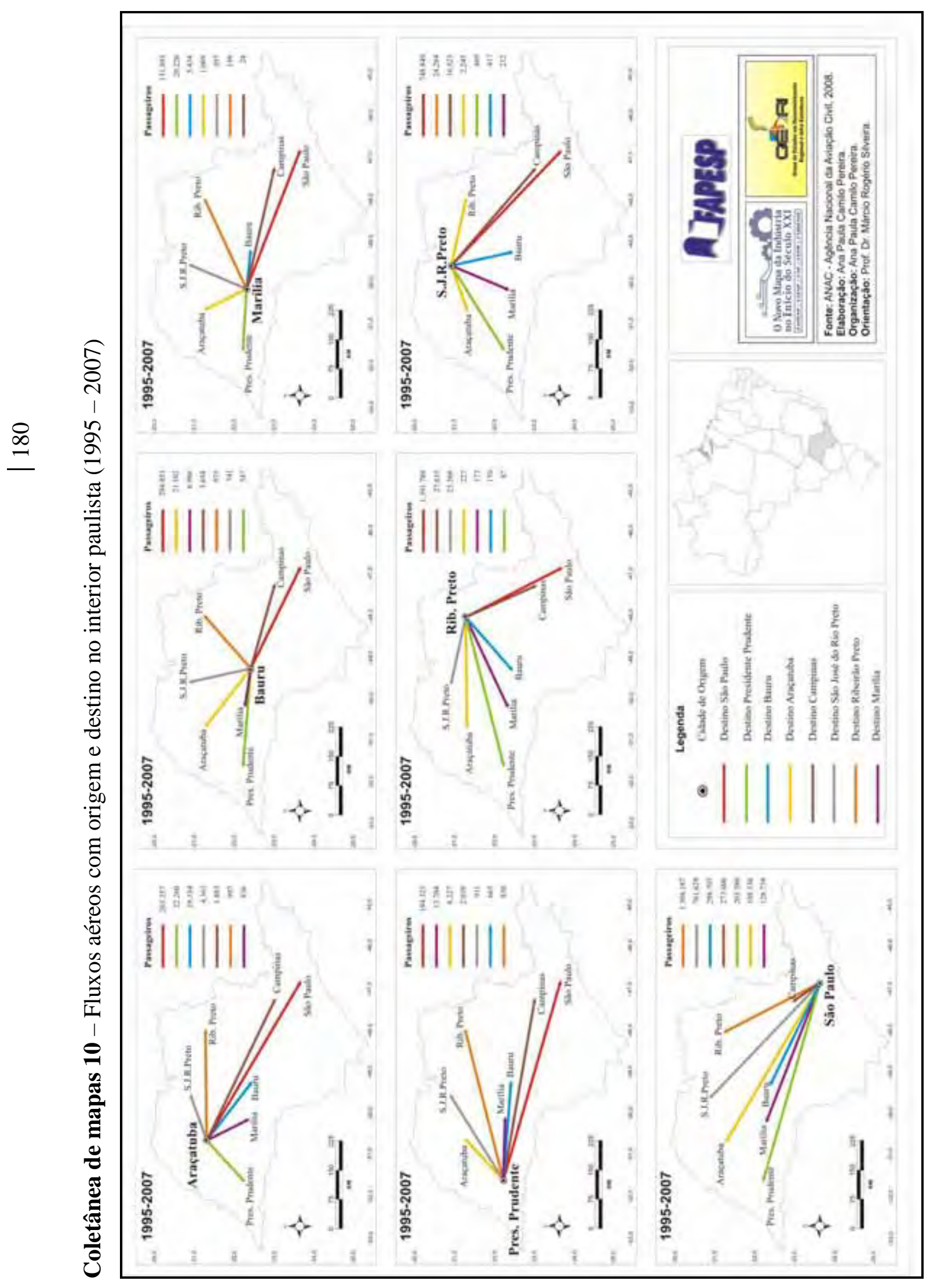


A representatividade das cidades do interior paulista consubstancia o crescimento do setor aéreo regional a partir das novas territorialidades, o que tem possibilitado novos arranjos de desenvolvimento. Mesmo em meio às constantes crises nas quais o setor está inserido, a análise realizada neste trabalho enfatiza o desenvolvimento e o crescimento do setor, considerando a importância destas cidades no contexto regional, como nós da rede geográfica aérea do Estado de São Paulo, pois estas possibilitam o aumento das interligações espaciais entre os territórios, uma vez que o setor tem propiciado uma maior demanda pelo modal.

\subsection{Considerações finais ao capítulo III}

O desenvolvimento econômico do transporte aéreo regional, consubstanciado nas novas territorialidades e na viabilização do segmento regional, é proposto como forma de se incentivar a dinâmica do setor nas cidades aqui tratadas e, também, como uma possibilidade, baseada na intensidade das interações espaciais e na integração territorial, de valorização de outros pontos do território paulista.

No tocante a isso, o terceiro capítulo traz um enfoque sobre o desenvolvimento do setor aéreo no segmento regional, tendo para tal fim dados estatísticos que permitem uma análise quantitativa e qualitativa sobre o transporte aéreo. Nesse aspecto, tecemos considerações sobre o segmento regional e as novas territorialidades, enfatizando-se a base empírica elucidada, isto é, as cidades com aeroportos regulares, introduzindo seus papéis de centros de desenvolvimento, atração e influência em seus respectivos entornos.

As cidades paulistas compõem o perfil do setor aeroviário e caracterizam a potencialidade do transporte aéreo regional. Nessa perspectiva, apresentamos uma análise sintética dos fluxos aéreos entre cidades do interior paulista e destas com a capital São Paulo. Esta interconexão com a cidade de São Paulo expressa o processo de contiguidade centro-interior, elucidando a desconcentração urbano-industrial no Estado, no qual as atividades industriais deslocam-se rumo ao interior e o centro gestor continua centralizado no aglomerado metropolitano, induzindo e impulsionando as ligações aéreas.

As empresas aéreas têm registrado um importante cenário para aviação comercial regional. Apesar de algumas empresas do ramo terem abandonado suas operações no Estado, a demanda pelo modal não cessou; contraditoriamente, o ano de 2007 apresentou crescimento nos índices estatísticos da atividade aérea comercial no interior do Estado. Nessa óptica, observa-se, ainda, que uma intensa movimentação de passageiros em direção à capital paulista fomenta fluxos para demais pontos do território nacional, o que 
projeta uma maior viabilização para o transporte aéreo regional, mediante as ligações diretas entre cidades do Estado de São Paulo e demais cidades de outros Estados.

Notamos que as empresas com características nacionais, tais como a TAM Linhas Aéreas e a Gol Linhas Aéreas Inteligentes, têm manipulado as operações no setor, bem como têm investido em estratégias mercadológicas que sustentam suas atuações no mercado, fragmentando as empresas de pequeno e médio porte e acelerando o processo de falência e fusões, o que perpetua o duopólio existente no setor. No entanto, este fato não tem destituído a dinâmica do setor aéreo. Embora as empresas em questão combinem suas permanências em determinados pontos do território, como forma de preservação mútua de suas malhas de voos e de seus lucros, o transporte aéreo regional tem apresentado índices satisfatórios, favorecendo o aumento da frequência de voos e da malha de linhas.

Todavia, para que o setor de transporte aéreo e as companhias aéreas desenvolvam-se, é necessária a intervenção do Estado, bem como a combinação de um planejamento coerente de estratégias e de controle à concorrência predatória entre empresas de grande, médio e pequeno porte. Essas perspectivas são cruciais para o desenvolvimento do segmento regional e das empresas aéreas regionais e, igualmente, para a oferta de voos e de empresas aéreas que disponibilizam o serviço, no intuito de favorecer o usuário do modal aéreo.

Nesse sentido, o interior do Estado de São Paulo, juntamente à aglomeração metropolitana, caracteriza um potencial econômico para o país e tem capacidade de geração de tráfego aéreo compatível com o desenvolvimento territorial brasileiro. Desse modo, o projetamento e uma política de investimentos para os complexos aeroportuários destas cidades são capazes de intensificar a utilização pelo modal aéreo e de dinamizar o desenvolvimento econômico regional do interior paulista, pois o transporte aéreo não serve somente às cidades que possuem aeroportos, mas também a sua área de influência, gerando um impacto regional. 


\section{CAPÍTULO IV}

AS ESTRATÉGIAS COMPETITIVAS DO SETOR DE TRANSPORTE AÉREO REGIONAL E SUAS IMPLICAÇÕES TERRITORIAIS 
A sociedade convive com mecanismos de constante adequação às inovações que, comumente, geram a necessidade de novas estratégias e vantagens competitivas que criem e sustentem um desempenho superior, mesmo que momentâneo.

As transformações recorrentes da evolução socioespacial, dos ciclos econômicos, das revoluções logísticas, da concorrência, assim como do intenso uso das vantagens e facilidades que a tecnologia produz, têm feito com que, espacialmente, os lugares se contraiam num processo de aproximação legitimadamente explorado pela mundialização do capital, que ora converge, ora diverge economicamente os espaços de interesse do capital.

Tais desdobramentos estão inseridos num mercado global que coordena as características inerentes às mudanças, para que estas engendrem mais movimento, maior flexibilidade, inovações econômicas, reestruturação técnica e, sobretudo, um maior fluxo, seja de pessoas, mercadorias ou informações. A prerrogativa da sociedade atual possibilita, e, para isso, impõe as metamorfoses necessárias à mobilidade territorial (LÉVY, 2001).

A necessária circulação ocorre em razão de que não há produção sem circulação. Assim, o mercado é o principal agente mobilizador dos intensos e complexos movimentos territoriais. A articulação entre os territórios perpassa os limites espaciais e projeta-se temporalmente no contexto de análise. Desse modo, o transporte aéreo configura-se como um setor que tem absorvido as mais intensas transformações estruturais, tecnológicas, sociais e econômicas, as quais se revelam como um elemento sincronizado às estratégias de mercado.

Temos assim que a compatibilidade do desenvolvimento aéreo com as mudanças do paradigma técnico-econômico do complexo eletrônico, principalmente aquelas relacionadas à informatização, estimulam um ambiente de maior competitividade no mercado, configurando estratégias internas de gestão empresarial, processamento de dados, pesquisas de demanda, etc., fatores, estes, que coordenam e promovem vantagens competitivas entre as empresas.

Para Coutinho (1992), a aplicação da microeletrônica proporcionou uma constelação de produtos e serviços que está agrupada em um conjunto de setores, indústrias e segmentos na forma de um complexo eletrônico e informacional, densamente articulado pela convergência da tecnologia. Para o autor, todo esse processo engendrou a formação de um poderoso "cluster de inovações", capaz de penetrar amplamente em todos os setores da economia, configurando um novo paradigma tecnológico. 
Essas mudanças alteraram o padrão de concorrência entre as empresas. A competitividade tornou-se o imperativo do cenário atual, em que as intensas transformações tecnológicas e o processo de globalização impõem práticas e ações flexíveis e adaptáveis à dinâmica econômica vigente.

Neste capítulo, trataremos do setor de transporte aéreo regional a partir da perspectiva das empresas e da sua atuação no mercado, salientando que as mesmas constituem um componente da estruturação do setor de transporte aéreo. Para tanto, abordamos sinteticamente o processo de origem, evolução e desenvolvimento das empresas aéreas que operam no interior do Estado de São Paulo, retratando suas bases territoriais de operação, bem como as estratégias e vantagens competitivas que as sustentam, bem como suas repercussões espaciais/territoriais.

Nesta análise, adotamos como enfoque principal as estratégias competitivas utilizadas por essas empresas que convergem na estruturação do mercado aéreo regional paulista. Para isso, adotamos como referências principais as proposições teóricas de Michael Porter $(1986,1989,1999,2009)$ e os outros estudos relacionados à temática, que complementam as análises referenciadas. Buscamos, desta forma, explorar a iniciativa de compreender o processo interno de gestão, planejamento e execução do desempenho das empresas aéreas no mercado, conferindo para isso as intenções dessa competição, que por vezes torna-se cooperação, descaracterizando o papel da concorrência no transporte aéreo e implicando na existência fortificada da duopolização do mercado aéreo brasileiro. Dentro dessa perspectiva, analisamos quais os impactos territoriais nas cidades pesquisadas neste trabalho mediante as estratégias e o processo de concorrência das empresas aéreas.

\subsection{As empresas aéreas: origem, desenvolvimento e estratégias empresariais}

As companhias aéreas desenham uma organização espacial de frequência de seus voos e linhas que demonstram claramente a centralização dos fluxos no Centro-Sul do país. Identificar as principais companhias aéreas no Brasil e, consequentemente, no Estado de São Paulo, consiste em dizer que existem duas grandes companhias nacionais (TAM e Gol) que lideram o setor e que, concomitantemente, definem os padrões territoriais de atuação, bem como as estratégias de mercado, que são definidas a partir de seus interesses particulares. Essas companhias transformaram o setor num duopólio estratégico para permanência no mercado.

Entre as companhias aéreas que atuam no interior paulista em interface com a capital São Paulo tem-se: TAM Linhas Aéreas, Gol Linhas Aéreas Inteligentes, Pantanal 
Linhas Aéreas e a Passaredo Linhas Aéreas. A TAM opera linhas na escala regional, nacional e internacional; a Gol atua da mesma forma, porém com menor adesão do que a TAM; a Pantanal e a Passaredo operam voos regionais no Estado de São Paulo e em demais Estados da Federação ${ }^{59}$.

Embora se observe um crescente número de passageiros que passaram a utilizar o transporte aéreo em seus deslocamentos no Estado de São Paulo, a sazonalidade das empresas nas cidades pesquisadas é grande, devido à demanda de passageiros não ser, em muitos casos, suficiente para compensar os gastos das empresas em determinadas localidades. Soma-se a isso a concorrência com as grandes empresas do setor aéreo, que, na intenção de intensificar o duopólio do setor aéreo, promovem a concorrência nas cidades onde as empresas de pequeno e médio porte atuam.

Consideramos a importância da atuação das companhias TAM e Gol no cenário regional como relevantes estruturas empresariais de desenvolvimento para o segmento. Contudo, observa-se que o setor de transporte aéreo regional que, em tese, deveria fomentar a atuação de empresas regionais está, sistematicamente, sendo operado por duas companhias nacionais, que organizam o mercado e determinam as estratégias de controle e atuação das demais empresas no setor regional.

Tendo como prerrogativa o papel desempenhado por essas companhias no Estado de São Paulo, discorremos, a seguir, sobre a evolução e o desenvolvimento das mesmas, destacando suas origens, crescimento econômico, bem como suas bases territoriais de operações. Buscamos com isso apresentar o perfil das empresas e o contexto em que ampliaram e garantiram suas atuações no mercado aéreo brasileiro.

\subsubsection{TAM Linhas Aéreas S.A.}

A companhia TAM Linhas Aéreas iniciou suas atividades no ano de 1961, como empresa de serviços de táxi-aéreo no transporte de carga entre os Estados de São Paulo, Paraná e Mato Grosso. Criada por um grupo de pilotos na cidade de Marília, com o nome de TAM Transportes Aéreos Marília, a empresa desempenhava um papel relevante na colonização, desenvolvimento e integração de regiões do Norte do Paraná, Sul e Nordeste de Mato Grosso (GARÓFALO, 1982).

\footnotetext{
${ }^{59}$ Todavia, essas configurações foram constantemente redefinidas nos últimos anos e, por conseguinte elas deverão continuar, especificamente com o interesse da nova empresa aérea AZUL, que tem como objetivo expandir suas operações nas cidades médias ou pólos regionais do Brasil e, sobretudo do Estado de São Paulo. Estas novas configurações espaciais de atuação das empresas aéreas são notoriamente expressas pela expansão da empresa Passaredo, que tem sistematicamente aumentado sua área de operação.
} 
Baseada no processo de reestruturação urbana ocorrido no Estado, a companhia passou a sede de sua empresa para a capital paulista, concentrando suas linhas no setor regional, nas áreas delimitadas pelo antigo SITAR. Era responsável pela exploração do Sistema Centro-Oeste, nos Estados de São Paulo, Rio de Janeiro, Mato Grosso do Sul e parte do Mato Grosso; todavia, a expressividade das linhas processou-se com mais intensidade no Estado de São Paulo, favorecendo seu desenvolvimento e a consolidação de sua base territorial neste Estado.

A partir da análise e do conhecimento histórico da empresa TAM, observa-se que sua estrutura de desenvolvimento enquadra no que Perroux (1964) chama de "empresa embrião". Os conhecimentos estratégicos dos mecanismos de mercado fizeram com que a empresa, ao longo de períodos sucessivos, torna-se cada vez mais dominante.

A história da companhia TAM, que de empresa de táxi-aéreo passou a ser a principal companhia de transporte aéreo do Brasil, está associada à administração de seu proprietário, Comandante Rolim Adolfo Amaro. De acordo com Minadeo et al (2003), a TAM foi adquirida pelo comandante Rolim no ano de 1972, com grandes dificuldades financeiras e administrativas. Já no ano de 1976, a crise em que a companhia se encontrava havia sido superada, devido à administração do comandante Rolim. Surgia nesse cenário, a TAM Transportes Aéreos Regionais, que posteriormente daria origem a TAM Linhas Aéreas, de âmbito nacional e internacional.

O desenvolvimento da companhia baseou-se na compra de empresas aéreas regionais, o que diminuía a concorrência, impulsionava seu crescimento, aumentava o número de aeronaves disponíveis e, com isso, expandia a possibilidade de servir demais localidades do país.

Em 1986, a companhia adquiriu a Votec Serviços Aéreos Regionais, formando a BR Central (Brasil Central Linha Aérea Regional), com a qual passou a explorar voos para o Centro-Oeste e Norte do Brasil. No ano de 1996, comprou a Companhia Líneas Aéreas Paraguayas, surgindo assim a TAM Transportes Aéreos del Mercosur, com rotas para Montevideo, Buenos Aires, Assunción, Lima, Santa Cruz de la Sierra e Santiago (PIZZINATO et al 2005).

Em 1998, a TAM comprou a empresa Itapemirim Transportes Aéreos Regionais e a Helisul Linhas Aéreas, que passou a se chamar TAM Express. Neste mesmo ano, a empresa estreava no cenário internacional com o voo São Paulo-Miami. Em 1999, a Interexpress (ex-Itapemirim) e a TAM Express foram incorporadas à TAM Linhas Aéreas 
e, em 2000, a TAM Regional foi absorvida, formando a TAM Linhas Aéreas (FOUQUET, 2008).

Em 2004, a empresa TAM abriu seu capital, o que proporcionou sua consolidação financeira e a expansão de sua frota. Atualmente, a companhia é a primeira empresa no ranking do setor aéreo nacional, obtendo as maiores receitas do mercado aéreo. No ano de 2007, obteve em seu balanço patrimonial um lucro de $\mathrm{R} \$ 2,6$ bilhões (receita líquida), o que equivaleu a um crescimento de $11 \%$ em relação ao ano anterior, segundo dados da própria empresa. No mercado doméstico, a empresa obteve participação acumulada em 48,9\%, no ano de 2007, em relação a sua atuação no mercado aéreo nacional; já no mercado internacional de aviação, participou com 67,5\% no mesmo período.

Embora a companhia tenha aberto suas ações no mercado, a composição acionária (Tabela 12) da empresa é composta, em sua maioria, por ações ordinárias da própria $\mathrm{TAM}^{60}$, o que lhe proporciona continuar controlando a empresa, por ter direito a voto, assim como permite continuar consolidando sua marca no mercado.

Tabela 12 - Controle acionário da empresa TAM Linhas Aéreas - 2007

\begin{tabular}{c|c|c|c}
\hline Acionistas & Ações Ordinárias (\%) & Ações Preferenciais (\%) & Total \\
\hline $\begin{array}{c}\text { TAM Empreendimentos e } \\
\text { Participações S.A. }\end{array}$ & 84,56 & 20,77 & 46,10 \\
\hline Agropecuária Nova Fronteira & 0,13 & 0 & 0,05 \\
\hline Amaro Aviation Part. S.A. & 15,28 & 2,77 & 7,73 \\
\hline Minoritários & 0,03 & 76,46 & 46,11 \\
\hline Total & 100 & 100 & 100 \\
\hline
\end{tabular}

Fonte: Relatório TAM, 2008

Org.: Camilo Pereira, 2009

Atualmente, a companhia é tida como a principal empresa aérea do Brasil, ou a major player (OLIVEIRA, 2009) como é denominada nos estudos sobre o setor aéreo. Serve 42 cidades brasileiras e ainda mantém acordos comerciais firmados com companhias regionais, o que permite uma maior projeção geográfica do seu atendimento, ampliando, com isso, sua malha doméstica na aviação regional.

Os acordos comerciais estendem-se mundialmente. Entre as principais empresas internacionais que a TAM possui acordos comerciais, destacam-se: Air Canadá, BMI British Midland, Lan Airlines, Lufthansa, TAP Portugal e United Airlines.

\footnotetext{
${ }^{60}$ As empresas TAM Empreendimentos e Participações S.A. e a Agropecuária Nova Fronteira Ltda. pertencem à família Amaro.
} 
Dentre as bases territoriais de operação da empresa, destacam-se: Aracaju, Assunção, Belém, Belo Horizonte, Boa Vista, Brasília, Buenos Aires, Campinas, Campo Grande, Caxias do Sul, Comandatuba, Corumbá, Cuiabá, Curitiba, Florianópolis, Fortaleza, Foz do Iguaçu, Goiânia, Ilhéus, Imperatriz, Joinvile, João Pessoa, Lima, Londres (Heathrow), Londrina, Macapá, Maceió, Manaus, Marabá, Maringá, Miami, Montevidéu, Natal, Navegantes, New York (JFK), Palmas, Paris, Petrolina, Porto Alegre, Porto Seguro, Porto Velho, Recife, Ribeirão Preto, Rio Branco, Rio de Janeiro, Salvador, Santarém, Santiago, São José do Rio Preto, São Luís, São Paulo, Teresina, Uberlândia e Vitória.

O desenvolvimento da empresa repercutiu principalmente no Estado de São Paulo. A ampliação das linhas aéreas favoreceu as cidades do interior, primeiramente porque o planejamento das rotas dinamizou o oferecimento de cidades servidas pelo modal, mas também porque o crescimento da TAM gerou para o interior do Estado um maior "entrosamento" territorial com demais porções do território nacional. Os deslocamentos de pessoas e de mercadorias das cidades do interior e de suas regiões de influência foram, sistematicamente, beneficiados pelo transporte aéreo, uma vez que a TAM trouxe uma maior visibilidade econômica para o interior paulista, o que foi possível, também, em razão da desconcentração urbano-industrial.

\subsubsection{Gol Linhas Aéreas Inteligentes S.A.}

A empresa foi fundada no ano de 2000, pelo empresário Constantino de Oliveira Junior, herdeiro do Grupo Áurea ${ }^{61}$, um dos maiores grupos de transportes no Brasil. A Gol iniciou as operações em 15 de janeiro de 2001, com o objetivo de proporcionar voos com preços acessíveis para uma maior parcela da população brasileira.

A companhia é a segunda maior empresa do ramo de transporte aéreo no Brasil. A empresa inseriu-se no mercado provocando uma substancial transformação no setor de transporte aéreo, ao inaugurar no Brasil a estratégia de marketing de mercado "low-cost, low-fare", muito utilizada em países europeus e nos Estados Unidos, que consiste no conceito de baixo custo, baixa tarifa.

As tarifas mais baixas que a companhia oferece em relação às suas concorrentes fazem parte do círculo virtuoso que norteia o modelo de negócios da Gol. Custos mais baixos são revertidos em passagens mais baratas aos clientes. Com isso, o

\footnotetext{
${ }^{61}$ Em 1949, na cidade de Patrocínio (MG), teve início o Grupo Áurea, de Constantino Oliveira. No decorrer dos anos, o Grupo consolidou-se como um dos maiores grupos nacionais de transporte terrestre de passageiros. Atualmente, o Grupo é composto por 37 empresas urbanas, intermunicipais e interestaduais, com mais de 6 mil ônibus que transportam, em média, 36 milhões de passageiros/mês e emprega cerca de 25 mil pessoas, com faturamento superior a 1 bilhão de reais por ano (PIZZINATTO et al 2005).
} 
objetivo da empresa é popularizar a aviação comercial na América Latina ${ }^{62}$. A companhia entrou no mercado aéreo brasileiro com o objetivo de agregar demanda, procurando traçar um novo perfil para o setor no Brasil e tendo como principal característica para a constituição da empresa o passageiro sensível ao preço.

Burle (2003), ao discorrer sobre o setor aéreo no Brasil, assevera que a razão principal do crescimento da Gol foi resultado da permissão do Governo (DAC), que cooperou com a liberação de suas operações onde existia maior demanda, isto é, nos principais centros de operação do transporte aéreo. Conivência ou não, foi a partir das autorizações do DAC que a companhia garantiu uma parcela representativa do mercado aéreo.

A partir dessa liberação, a empresa passou a competir com empresas regulares sem ter as mesmas obrigações. Diferentemente das demais empresas, a Gol não precisou investir em treinamento de pessoal, pois o mercado, naquele momento, estava com oferta abundante de mão-de-obra qualificada, em razão do processo de falência da VASP e da Transbrasil (BURLE, 2003).

Esse cenário do mercado aéreo brasileiro favoreceu a inserção estratégica da empresa Gol que planejou suas operações na constituição de um novo padrão de comercialização de passagens aéreas, utilizando-se de estratégias mercadológicas que impulsionaram o crescimento da empresa no setor.

De acordo com Burle (2003), o crescimento da empresa deve-se, principalmente, aos fatores de redução de custos, principalmente porque tal iniciativa permitiu minimizar os preços das passagens aos usuários, fomentando a demanda e a preferência pela empresa.

Sua consolidação se deu no ano de 2004, quando a companhia abriu seu capital lançando suas ações nas bolsas de São Paulo (Bovespa) e de Nova York (NYSE). Tal fato possibilitou à empresa a captação de recursos que foram investidos na modernização da frota. Nesse momento, foi criada a Gol Linhas Aéreas Inteligentes S.A., para controlar a Gol Transportes Aéreos S.A..

Estruturada em meio à crise aérea que o setor ainda convive, a Gol apresenta hoje um novo panorama para o transporte aéreo, que tem intensificado a falência de empresas que se baseiam no padrão tradicional da aviação comercial, ou seja, aquele que

\footnotetext{
${ }^{62}$ No Brasil, as tarifas médias dos voos domésticos já foram reduzidas em mais de $30 \%$. De 100 milhões de passageiros que já voaram pela companhia, cerca de 10 milhões viajaram pela primeira vez de avião com a Gol. Ou seja, o modelo de baixo custo foi aderido com sucesso no cenário brasileiro (RELATÓRIO CASE GOL, 2009).
} 
prevê a sofisticação para a manutenção social do transporte aéreo. $\mathrm{O}$ enquadramento de gestão e operação da empresa constitui-se na opção de padronização única das classes de voos, que se baseiam na principal estratégia da empresa, já que compreende voos com custos mais acessíveis em uma única classe de serviços.

O grande salto da empresa foi a aquisição da VARIG, nomeada atualmente como VRG. Segundo Salgado (2009), a Gol comprou, no dia 28 de março de 2007, por US\$ 320 milhões, a VRG, realizando o maior negócio da aviação civil já realizado no país. Do total da transação, US\$ 275 milhões foram destinados para o pagamento de aquisição do controle, além de mais $\mathrm{R} \$ 100$ milhões relativos ao compromisso de honrar debêntures (títulos) emitidas pela VARIG. O pagamento de US\$ 275 milhões será feito com $10 \%$ do caixa (US\$ 98 milhões) da Gol e com a entrega de cerca de 6,1 milhões de ações preferenciais emitidas, que representam, aproximadamente, $3 \%$ do total de papéis da companhia $^{63}$.

No ano de 2001, a Gol era a $5^{\mathrm{a}}$ maior empresa brasileira de transporte aéreo. Em 2007 encontrava-se em $2^{\circ}$ lugar, no ranking das empresas aéreas brasileiras, o que demonstra o crescimento da empresa. Sua estrutura societária é predominantemente nacional ${ }^{64}$, conforme descrito na Tabela 13:

Tabela 13 - Controle acionário da empresa Gol Linhas Aéreas Inteligentes - 2007

\begin{tabular}{c|c|c|c}
\hline Acionistas & Ações Ordinárias (\%) & Ações Preferenciais (\%) & Total \\
\hline $\begin{array}{c}\text { Fundo de Investimento em } \\
\text { Participação Asas }\end{array}$ & 100 & 38 & 71 \\
\hline Administração & $*$ & 3 & 1 \\
\hline Mercado & 0 & 59 & 28 \\
\hline Total & 100 & 100 & 100 \\
\hline
\end{tabular}

* Menos de $1 \%$

Fonte: Gol Linhas Aéreas Inteligentes, 2009

Org.: Camilo Pereira, 2009

A Gol tem uma área de alianças com o objetivo de dar suporte às operações internacionais da companhia. Atualmente, a empresa possui acordos de interline ${ }^{65}$ com a

\footnotetext{
${ }^{63}$ É importante destacar que o Governo (ANAC) teve papel relevante na negociação de compra da VARIG pela Gol. Fica claro que a intermediação do Governo nesse processo ocorreu em razão do próprio partidarismo de interesses da ANAC. Todavia, essa intermediação do Governo não representou a propriamente um papel de relevância e de intervencionismo direto do Governo, mas sim uma mera "arbitragem" comercial.

${ }^{64}$ A legislação aeronáutica brasileira limita a $20 \%$ o capital estrangeiro em companhias aéreas nacionais. Tal fato já evidencia uma barreira à entrada de natureza regulatória na revisão da legislação. De acordo com Salgado (2009, p. 14), "trata-se da limitação imposta pelo Código Brasileiro de Aeronáutica (CBA) para a participação de capital estrangeiro no controle de companhias aéreas nacionais em 20\%. Alterada tal disposição legal, abrir-se-ia caminho para injeção de capital em empresas entrantes e recém-instaladas".

${ }^{65}$ Interline: baseado nas proposições utilizadas pela empresa Gol significa "acordos de operações".
} 
Aegean (Grécia), Aerolineas Argentinas (Argentina), Air Comet (Espanha), Air France (França), Air Moldova (Moldova), Air One (Itália), American Airlines (Estados Unidos), China Airlines (Taiwan), Condor Airlines (Alemanha), Continental Airlines (Estados Unidos), CSA Czech (República Tcheca), Delta Air Lines (Estados Unidos), El Al (Israel), Etihad Airways (Emirados Árabes Unidos), Hahn Air (Alemanha), Ibéria (Espanha), Japan Airlines (Japão), KLM (Holanda), Korean Air (Coréia do Sul), LOT Polish Airlines (Polônia), Malev (Hungria), Mexicana (México), Qatar Airways (Qatar), TAP Portugal (Portugal), Turkish Airlines (Turquia) e Ukraine International Airlines (Ucrânia). Além disso, desde 2004, a Gol mantém um acordo de codeshare $^{66}$ com a Copa Airlines (Panamá).

A companhia atende diversas localidades no Brasil, tais como: Aracajú; Assunção, Belo Horizonte, Belém-PA, Boa Vista, Brasília-DF; Buenos Aires, Campina Grande, Campinas, Campo Grande, Caxias do Sul, Chapecó, Córdoba, Cuiabá, Curitiba, Florianópolis, Fortaleza, Foz do Iguaçu, Goiânia, Ilhéus, Imperatriz, Joinville, João Pessoa, Juazeiro do Norte, Lima, Londrina, Macapá, Maceió, Manaus, Maringá, Montevidéu, Natal, Navegantes, Palmas, Petrolina, Porto Alegre, Porto Seguro, Porto Velho, Presidente Prudente, Rio de Janeiro, Recife, Ribeirão Preto, Rio Branco, Rosário, Santa Cruz de la Sierra, Santarém, Santiago, Salvador, São José do Rio Preto, São Luís, São Paulo, Teresina, Uberlândia e Vitória.

A principal base territorial da empresa Gol é o Estado de São Paulo, devido, entre diversos fatores, a representatividade econômica do Estado que fomenta uma maior circulação. A atuação da empresa nas cidades paulistas tem ampliado o potencial do transporte aéreo, em razão, da própria política administrativa da Gol, ou seja, de tarifas mais acessíveis aos consumidores. A permanência da empresa na cidade de Presidente Prudente tem estimulado o desenvolvimento aeroportuário da cidade e de sua região. De acordo com o DAESP, o crescimento do setor de transporte aéreo na cidade é o maior do Estado de São Paulo. Entre os anos de 2007 e 2009 houve um crescimento de 300\% no número de passageiros que utilizam o modal aéreo.

\subsubsection{Pantanal Linhas Aéreas S.A.}

A empresa Pantanal foi fundada no ano de 1993 - com o nome de Pantanal Linhas Aéreas Sulmatogrossenses S.A., originária da Pantanal Táxi-aéreo - pelo

\footnotetext{
${ }^{66}$ Codeshare: caracteriza-se como uma prática de mercado na qual as companhias aéreas compartilham aeronaves (OLIVEIRA, 2009).
} 
empresário Marcos Sampaio Ferreira, ex-controlador da empresa Bombril. A empresa opera comercialmente serviços regulares de linhas aéreas de passageiros e cargas e oferece serviços aéreos em três Estados da Federação: Paraná, Minas Gerais e São Paulo, sendo este último o Estado em que a empresa tem maior atuação.

No ano de 2008, a Pantanal confrontou-se com um período de crise no setor aéreo brasileiro, que coincidiu com o arrefecimento da empresa, ampliando a gravidade da crise. Os motivos que provocaram restrições na operacionalização da empresa concerniam a não entrega de documentos comprobatórios de pagamentos, de impostos e de obrigações trabalhistas, além de informações sobre a irregularidade técnica e operacional da companhia. No entanto, a empresa obteve aval da ANAC para operar por mais seis meses, vencido no dia vinte e cinco de julho do mesmo ano. Contudo, a empresa ainda continua a operar com prorrogação de aval concedido pela ANAC.

A Pantanal Linhas Aéreas tem manifestado constantes crises, sobretudo devido ao valor de sua dívida, que ultrapassa 30 milhões de reais. Seu diretor-proprietário, Marcos Sampaio Ferreira, tem manifestado interesse na venda da empresa para a TAM Linhas Aéreas.

A empresa Pantanal oferece voos para os seguintes destinos: Araçatuba, Bauru, Juiz de Fora, Marília, Maringá, Presidente Prudente e São Paulo. Apesar de ser uma empresa de pequeno porte no cenário da aviação comercial, o fechamento da Pantanal significa a redução da importância do transporte aéreo regional no Estado de São Paulo. As rotas operadas pela mesma perfazem a principal ligação da capital paulista com o interior do Estado, sobretudo com as principais cidades que operam voos regulares, tais como: Araçatuba, Bauru, Marília e Presidente Prudente.

\subsubsection{Passaredo Transportes Aéreos LTDA}

A Passaredo Transportes Aéreos faz parte do Grupo Passaredo. Com sede na cidade de Ribeirão Preto, atua no ramo de transporte rodoviário nos setores urbano, fretamento e turismo e no setor aéreo.

De acordo com entrevistas realizadas na empresa, a Passaredo foi fundada no ano de 1978, desenvolvendo-se, primeiramente, no setor rodoviário. Em 1995, seu então presidente, José Luiz Felício, criou a Passaredo Transportes Aéreos na intenção de expandir seus investimentos no ramo de transporte. Em 2002, as operações da Passaredo foram suspensas, retornando às atividades no ano de 2004, com uma estrutura moderna e 
um reposicionamento estratégico. A partir desse ano, as operações passaram a ser administradas por José Luiz Felício Filho.

A Passaredo tem se destacado como a principal empresa aérea regional no Estado de São Paulo, sendo indicada como uma das perspectivas de crescimento do segmento aéreo regional paulista. Atua com uma intensa malha de fluxos na cidade de Ribeirão Preto (principal hub do interior paulista), o que tem lhe proporcionado receitas crescentes.

No Estado de São Paulo, a empresa oferece os serviços aéreos para a cidade de Ribeirão Preto, na interconexão com a metrópole paulista e com São José do Rio Preto e, recentemente inaugurou linhas aéreas de Presidente Prudente para São Paulo, com escalas nas cidades de Marília e Bauru. Essa estratégia de escalas nessas cidades tem um duplo interesse. O primeiro corresponde a ação estratégica que toda empresa aérea faz quando organiza sua malha de voos com escalas, ou seja, aumentar a densidade de passageiros que utilizam o modal aéreo. O segundo e, mais importante interesse, refere-se ao estudo de demanda origem-destino. Em outras palavras significa que, as escalas em Marília e Bauru permitem a Passaredo compreender onde há a maior demanda pelo transporte aéreo, ou seja, qual a origem dos passageiros - se em Presidente Prudente, Bauru ou Marília -, e qual o destino que esses buscam quando tem origem em São Paulo.

A entrada da Passaredo no mercado de Presidente Prudente é resultado de estudos de demanda origem/destino e representa uma ampliação inicial da empresa no Estado de São Paulo. A sazonalidade da empresa consistirá nos resultados advindos dessa nova linha aérea no Estado de São Paulo.

As expectativas do mercado aéreo paulista indicam que a Passaredo está entre as empresas regionais que mais tem demonstrado crescimento, por possuir voos diretos para centros urbanos não eslotados, sem conexão ou escala em São Paulo, estratégia esta, em pleno desenvolvimento no setor aéreo brasileiro.

Nos últimos anos, a malha de voos da empresa Passaredo tem-se estendido para demais Estados, favorecendo o crescimento da empresa. Dentre as operações aéreas oferecidas, destacam-se: Barreiras, Bauru, Belo Horizonte, Brasília, Cuiabá, Curitiba, Goiânia, Marília, Porto Alegre, Presidente Prudente, Ribeirão Preto, Rio de Janeiro, Salvador, São José do Rio Preto, Uberlândia, Vitória da Conquista e São Paulo.

A Passaredo é a principal empresa regional do Estado de São Paulo. Suas ações no mercado aéreo implicam necessariamente em transformações na cidade de Ribeirão Preto, já que esta cidade corresponde a sua base territorial. No entanto, a atuação da 
empresa tem se ampliado no território paulista para além de Ribeirão Preto. A Passaredo tem investido em novos mercados do Estado, tendo como principal alternativa a cidade de Presidente Prudente, devido esta ter apresentado índices positivos nos fluxos aéreos. A entrada da empresa em novos mercados reflete uma postura mais agressiva frente às empresas de pequeno porte, uma vez que a Passaredo tem demonstrado estratégias competitivas que ora constituem um processo de cooperação com as grandes empresas, ora manifestam seu diferencial de mercado. Esse fator gera benefícios para as cidades com aeroportos regulares, já que estas dispõem de uma maior oferta de empresas operando no mercado, assim como as destacam como importantes centros econômicos do Estado.

\subsection{Estratégias e vantagens competitivas: a concorrência no setor de transporte aéreo regional}

No contexto da mundialização do capital, das transformações conjunturais, das estratégias empresariais, das formas flexíveis de produção e comercialização, a necessidade de otimizar o processo concorrencial entre as empresas amplia-se mediante o mercado. A dinâmica empreendida é funcionalmente seletiva e espacial, ou seja, a adequação às mudanças gerais é condição primordial para a manutenção e permanência no mercado.

Pons e Reynes (2004, p. 192) destacam que "una de las consecuencias de los procesos de desregulación de los mercados de transporte aéreo ha sido el proceso de reestructuración de compañías aéreas. Éstas han tenido que adaptarse a la libre competencia y disputarse los mercados."

No exame sobre a competitividade no mercado aéreo brasileiro, tomamos como definição principal a abordagem enfatizada por Kupfer (1996), para quem a competitividade é explicada como a capacidade da empresa formular e implementar estratégias concorrenciais, que lhe permitam ampliar ou conservar, de forma duradoura, uma posição sustentável no mercado. Mas, a competitividade não se restringe apenas a estrutura de mercado. A competição também é definida mediante a necessidade imposta pelo usuário. Desta forma, além da organização interna, as empresas precisam constantemente adequar-se ao que o usuário necessita, seja em relação ao preço das passagens aéreas, a qualidade do serviço oferecido, a disponibilidade de recursos tecnológicos que garantam a praticidade e a facilidade para o usuário.

Nesse mesmo raciocínio, temos que as bases da competitividade estão diretamente ligadas à capacidade de inovar (COUTINHO, 1992). A velocidade das ações e 
das transformações em todo processo produtivo, desde a fase inicial até a circulação e o consumo em si, tem maximizado a incorporação de estratégias que já não mais estão apenas relacionadas às técnicas de administração interna das empresas, mas também ao padrão de permanência e inovação das empresas. João (2005) descreve esse processo da brevidade das transformações enfatizando que quando a velocidade de mudanças nas tecnologias torna-se extremamente rápida, a estratégia tem o seu papel valorizado.

A implicação dessas ações inovativas nas cidades pesquisadas, pode ser melhor compreendida quando analisamos os investimentos das empresas em seus locais de operação. Mediante as visitas realizadas nos aeroportos, como forma de reconhecer o padrão tecnológico utilizados pelas empresas, observamos que atualmente, os usuários dispõem de tecnologias antes utilizadas apenas nos grandes fixos do setor de transporte aéreo, isto é, em aeroportos nacionais e internacionais. Assim, observa-se que a utilização de plataformas de auto-atendimento com a finalidade de operar atividades antes realizadas por pessoal especializado, hoje, pode ser feita pelo próprio usuário, que eletronicamente realiza suas operações de voos nessas plataformas.

Este tipo de equipamento foi encontrado nos aeroportos de Ribeirão Preto e São José do Rio Preto, o que valida a maior participação desses centros urbanos no setor de transporte aéreo paulista. Ressaltamos, que a utilização da tecnologia nos aeroportos regionais tem induzido um maior dinamismo, refletindo nas cidades a adequação tecnológica desses fixos, o que as tornam mais competitivas. Tal iniciativa personifica o interesse das empresas aéreas nesses centros urbanos identificando-os como aeroportos privilegiados do ponto de vista da competitividade inter-regional.

Com isso, o papel das estratégias mercadológicas aborda as ações das empresas que se utilizam principalmente da tecnologia para investirem e permanecerem no mercado do setor de transporte aéreo. Ao discutir as análises sobre as estratégias empresariais no setor de transporte aéreo, propõe-se uma abordagem a partir das bases conceituais de Michel Porter (1986, 1989, 1996; 1999), que descreve a função da vantagem competitiva no mercado concorrencial ${ }^{67}$. Para o autor, a necessidade de criar vantagens competitivas é

\footnotetext{
${ }^{67}$ As análises de Michael Porter partem de uma proposta que tem a empresa como o fator principal do mercado, isto é, a empresa é responsável por todo processo de desenvolvimento do mercado, da indústria, do consumo, das estratégias etc. Buscamos evidenciar a empresa como um importante vetor de manipulação do mercado, assim como da indústria aeronáutica e, principalmente, das competências de estratégias que as fazem permanecer no mercado. No entanto, ressaltamos que a proposta dessa pesquisa insere-se numa perspectiva que perpassa a análise exclusiva da empresa e tomamos como determinantes do desenvolvimento da aviação comercial o Estado, os agentes privados, as cidades que possuem aeroportos regulares, a sociedade que consome esse serviço, a indústria que busca por meio da venda incrementar tecnologicamente este setor, entre outros agentes fomentadores do transporte aéreo.
} 
fundamental para consolidação num mercado competitivo, uma vez que é mediante a estratégia e a inovação corporativa que as empresas conseguem manipular e constituir um mercado de acordo com seus interesses.

Atualmente, a tecnologia tornou-se uma ferramenta capaz de arregimentar a estrutura empresarial de empresas que sobrevivem da capacidade de inovar e, ainda, constitui uma eficaz vantagem competitiva. A revolução da informação (PORTER, 1999) tornou-se de perto o que se denomina de sustentabilidade da vantagem competitiva. Não há dúvidas de que a tecnologia da informação tornou mais tecnicamente eficaz o processo de comercialização das empresas aéreas, sobretudo quando se trata do $e$-commerce.

$\mathrm{Na}$ medida em que uma empresa consegue obter lucros alicerçados em sua capacidade de inovar informatizando-se, aperfeiçoando-se e criando estratégias potenciais, considera-se que essa empresa possui uma cadeia de valores capaz de solidificar as estratégias em seu favor.

Exemplos de como a tecnologia tem favorecido a consolidação das companhias no mercado aéreo são verificados na própria comercialização das empresas que utilizam a internet como o principal canal de vendas, terminais de auto-atendimento e call center para check in, serviços de telefonia, atendimento on line, entre outros.

No entanto, é importante salientar que a própria inconstância da tecnologia é um entrave ao comportamento e as estratégias das empresas. Assim, as estratégias competitivas adotadas pelas empresas irão refletir nas escolhas individuais feitas de acordo com suas prioridades, que se impõe a cada momento.

A tecnologia não é uma panacéia que assegura o sucesso na conquista ou manutenção de mercados, tanto mais porque a best-practice relevante neste campo não é absoluta (a mais avançada das técnicas disponíveis) mas, tautologicamente, é relativa, mas é a mais competitiva dentre as técnicas existentes (KUPFER, 1992, s/pag).

A tecnologia, ao mesmo tempo que cria a vantagem competitiva, influi na incorporação de novas formas de aperfeiçoamento e melhoramento, uma vez que as vantagens competitivas são temporárias, pois nada impede que uma empresa copie as estratégias de sua concorrente e, por conseguinte, exclua a vantagem competitiva que a empresa possui no mercado (PORTER, 1996).

Hasenclever e Tigre (2002) consideram que o novo saber tecnológico é um bem público. Assim, a concorrência pode fazer uso sem restrição, gerando a estratégia de imitação, caracterizada por ser a mais comum em qualquer mercado comercial. 
A imitação de estratégia competitiva é observada nos aeroportos regionais do Estado de São Paulo, principalmente no que diz respeito a escolha das linhas operadas. Um exemplo pode ser considerado na recente atuação das empresas aéreas na cidade de Presidente Prudente. Após a entrada da Gol no mercado desta cidade, as operações aumentaram no mercado prudentino, ampliando o lucros da empresa, ou seja, contribuiu para implementar uma vantagem competitiva da empresa sobre as demais. Mediante a projeção da Gol neste mercado e suas ligações com a capital paulista, a empresa Passaredo deslocou suas operações para a cidade de Presidente Prudente, induzindo o que Hasenclever e Tigre (2002) chamam de "estratégia da imitação".

No entanto, é importante destacar que tal estratégia, nas circunstâncias expressas anteriormente, contribui para a dinâmica econômica das cidades, já que isso gera maior competitividade entre as empresas, o que reflete em mais ligações aéreas, demais destinos, melhores preços e maiores facilidades na aquisição das passagens.

No mercado da aviação comercial, a prática da cópia de inovações, principalmente no campo da tecnológica, da organização e da gestão, faz parte de um processo incontrolável, embora a propriedade intelectual e o ineditismo da inovação sejam atribuídos à empresa que gerou a inovação. No entanto, nada impede que as demais empresas se apropriem e a utilizem como uma estratégia, mas não como uma vantagem competitiva. Por isso, enfatiza-se a temporalidade da vantagem competitiva, uma vez que a estratégia da imitação inibe e por vezes exclui a vantagem competitiva do concorrente.

É o posicionamento estratégico que exerce a distinção das atividades em relação aos rivais, ou seja, exercer atividades semelhantes de um modo diferente constitui uma vantagem competitiva que é sustentada por uma estratégia eloquentemente distinguível e compulsoriamente exequível.

No entanto, Porter (1989), ao versar sobre as vantagens competitivas e sua funcionalidade no interior das empresas, destaca que:

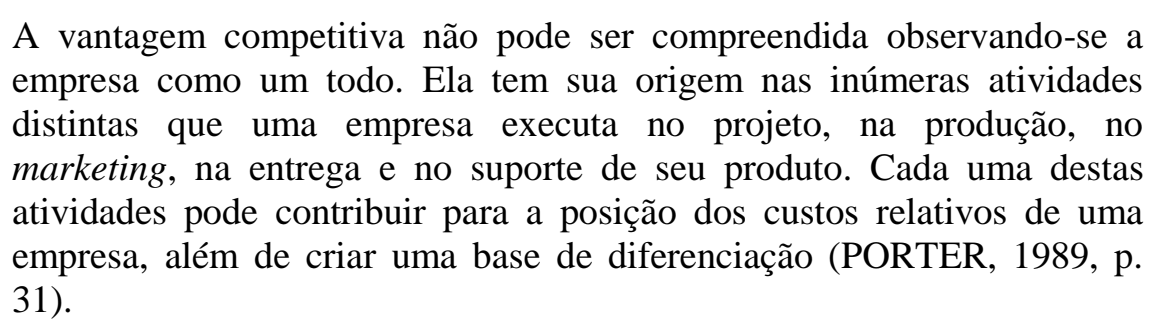

São nessas circunstâncias de diferenciação, inovação e concorrência produtiva que se encontram as bases da vantagem competitiva, as quais inserem as estratégias de mercado mediante a própria ação e reação das empresas no mercado. Desta forma, destaca- 
se que a função da vantagem competitiva é criar e sustentar um desempenho superior capaz de controlar, ao menos por um tempo, um padrão que seja potencialmente eficaz para neutralizar a concorrência.

Hasenclever e Ferreira (2002), em suas análises sobre o estudo da inovação tecnológica no enfoque da concorrência admitem que as inovações criam uma ruptura no sistema econômico, estabelecendo uma diferenciação visível entre as empresas e os locais onde atuam, que hierarquicamente passam a se distinguir. Isso induz o entendimento de que as cidades analisadas são espaços geográficos que permanentemente são produzidos e, ao mesmo tempo, produzem dinâmicas espacialmente determinadas por sua posição hierárquica. Em outras palavras, a partir do papel exercido por cada centro urbano é possível compreender a relevância de determinadas cidades na rede urbana brasileira e paulista. O melhor exemplo é a cidade de Ribeirão Preto que possui uma posição hierárquica superior, ou seja, com nível de centralidade muito forte ${ }^{68}$ (SPOSITO, 2004) o que conduz entender o porquê deste mercado apresentar o maior número de passageiros transportados e um maior interesse das empresas aéreas em operar nessa cidade.

Possas (2002) também destaca a teoria schumpeteriana, afirmando que a concorrência na economia capitalista passa a ser vista como um processo evolutivo, dinâmico, gerado por fatores endógenos ao sistema econômico. Notadamente, essas inovações emergem incessantemente da busca de novas oportunidades lucrativas por parte das empresas de acordo com sua interação competitiva.

Embora a concepção schumpeteriana e mesmo a neo-schumpeteriana apresentem um determinismo tecnológico que tem como preocupação central a lógica do processo de inovação e seus principais impactos sobre as atividades econômicas, enfatizamos a riqueza de suas proposições, no que tange ao papel da mudança tecnológica, que constitui um fator preponderante na conformação da estrutura de mercado e no processo de mudança estrutural, assim como na atribuição do relevante papel das companhias aéreas no mercado paulista.

Destacamos, a partir dessa perspectiva, que o objetivo das empresas é criar, constantemente, vantagens competitivas que as constituam como centrais no mercado aéreo. Assim, as estratégias das companhias aéreas cumprem um papel de definição nesse processo de configuração do mercado de transporte aéreo regional, mas ao mesmo tempo, esse processo é oposto.

\footnotetext{
${ }^{68}$ A autora considera como centralidade a área de influência que os centros urbanos exercem sobre seu entorno e sobre demais centros urbanos.
} 
Quando esse processo é materializado nas cidades paulistas constitui, mesmo que hipoteticamente, uma hierarquização dos aeroportos mediante a movimentação dos fluxos de passageiros, repercutindo economicamente. Na medida em que um centro urbano passa a demandar uma oferta crescente de voos, consequentemente gera uma maior atração das empresas aéreas, aumentando com isso a dinâmica econômica das cidades e de sua região. Em outras palavras, ora as empresas modelam o mercado mediante seus interesses, ora a própria dinâmica das cidades induzem as estratégias e o interesse dessas empresas aéreas.

Mediante tal assertiva e de acordo com as entrevistas realizadas, observamos que há no setor de transporte aéreo e, mais precisamente no segmento regional, dois grupos de companhias, aquelas de grande porte que coordenam a dinâmica do mercado e; as de pequeno e médio porte que estão sistematicamente suscetíveis as consequências das estratégias empresariais e espaciais organizadas pelas grandes empresas. Ambas têm interesses substancialmente diferentes - uma vez que suas ações têm causa e consequência diferentes, mas que no conjunto perfazem uma única função, isto é, dinamizar suas operações em aeroportos ainda não eslotados.

As grandes companhias aéreas, tais como a TAM e a Gol, interessam-se pelo mercado regional paulista porque este se caracteriza como um espaço altamente promissor, primeiro porque a desconcentração urbano-industrial ainda está em processamento, e isso fomenta as interligações entre capital e interior e do interior para a capital. Segundo, porque a atuação nesse segmento permite a visibilidade da marca da empresa nas cidades paulistas, além de favorecer o preenchimento de suas linhas nacionais e internacionais (pois muitas vezes o usuário tem destino para outros Estados e países e necessitam fazer escalas/conexões em São Paulo); e ainda faz com que suas ações impliquem no crescimento das pequenas e médias empresas ${ }^{69}$, que geralmente atuam nos mercados regionais.

Esta estratégia de atuação no mercado aéreo repercute diretamente nesses territórios, uma vez que o mercado (a cidade e seu entorno) é beneficiado com o serviço e com a imagem da "grande empresa consolidada". Além disso, os benefícios e resultados das ações estratégicas visam, ainda que indiretamente, a promoção do setor nesse segmento, o que é diretamente proporcional ao crescimento do transporte aéreo, ao

\footnotetext{
${ }^{69}$ Essa estratégia é conhecida como "barreira à entrada", ou seja, quando uma empresa atua num mercado com o fim único de impedir a expansão de outras empresas.
} 
aumento das interações espaciais e, consequentemente gera desenvolvimento econômico, urbano e regional.

No que tange a atuação das pequenas e médias empresas, observamos que estas geram um efeito também positivo para o mercado regional, contudo em menor proporção que as grandes companhias. Porém, as articulações entre as grandes, médias e pequenas empresas incidem, por vezes, negativamente nesses territórios, já que quando esses acordos se efetivam, constituindo mais uma ação estratégica, os usuários deixam de dispor da concorrência empresarial. Se por um lado, as alianças empresariais trazem uma perspectiva de crescimento, permanência ou liderança para as companhias - que com isso disponibilizam mais linhas e servem mais cidades -; por outro lado, impacta diretamente na ausência de "preços", que em síntese, atrai o consumidor.

Nesse sentido, é possível compreender que as estratégias das empresas aéreas definem situações que engendram um desenvolvimento econômico para as cidades que operam voos. Ao mesmo tempo em que as empresas competem pela permanência em determinados aeroportos, estas realizam funções de agente modelador do mercado, ampliando a dimensão de conectividade destas cidades com outras localidades, permitindo as interações espaciais e a integração territorial. A dinâmica do transporte aéreo passa necessariamente pela ação das empresas aéreas e o resultado desse processo de inovações, de contradições e de estratégias positivas ou negativas é manifestado nas cidades.

As estratégias competitivas, simultaneamente, induzem o progresso técnico operacional e a estrutura de organização das empresas. Para tal análise, tomamos o papel das inovações tecnológicas, as estratégias de mercado, a estrutura de organização das empresas e os resultados advindos da competição no mercado aéreo brasileiro e, sobretudo, paulista, como os principais fatores a serem compreendidos.

Baseados na proposta de Porter (1986) adotamos a concorrência como o principal componente que engendra a reestruturação empresarial, as estratégias de mercado, a tendência a inovar constantemente e de inserir-se como potencial concorrente no mercado competitivo. Partimos das análises das estratégias empresariais para compreender o processo de configuração do mercado de transporte aéreo no Estado de São Paulo, focando as ações das empresas que atuam em aeroportos do interior e inserindo uma propositura empírica de como essas empresas manifestam-se e posicionam-se frente à competição e quais os impactos advindos desse processo.

A estratégia competitiva engloba diversos e potenciais fatores de análise, como, por exemplo, definir se a ênfase estará no planejamento operacional ou na prestação 
dos serviços, no custo do que é produzido ou na diferenciação do produto que é oferecido. Os critérios da concorrência são definidos pelo mercado. Contudo, são as empresas que produzem o cenário para que o mercado dinamize-se, mediante as necessidades do usuário. Com isso, a materialização das formas, ou seja, do desenvolvimento do transporte aéreo, se dá de acordo com os sistemas de normas, ações e objetos. Dessa forma, a estratégia deve contemplar a empresa e, num processo análogo, deve fomentar as necessidades do seu mercado.

Assim, iniciamos uma abordagem sobre as estratégias de concorrência das empresas aéreas brasileiras, enfatizando suas estratégias empresariais e suas vantagens competitivas, referindo-nos as suas ações e reações no mercado de transporte aéreo paulista.

\subsection{Estratégias empresariais: cadeia de valor, inovação, diferenciação/diversificação e coerência produtiva}

A macrodinâmica capitalista produz um escopo competitivo capaz de gerar funções que, frequentemente, se inovam no intuito de incorporar ao ambiente empresarial a noção da diferenciação competitiva. Em outras palavras, significa dizer que as empresas constroem um cenário de intensas transformações e estas são impostas como forma de se gerar vantagens que determinam a diferenciação, a inovação e a coerência produtiva.

Nesse contexto, Porter (1989) analisa esse processo subdividindo-o de acordo com os princípios da vantagem competitiva, quais sejam: a cadeia de valor ${ }^{70}$, a vantagem de custo, a diferenciação do produto e a capacidade de inovar tecnologicamente. Dentre suas contribuições, Porter (1989) assevera que há muito para aprender sobre os motivos do melhor desempenho de algumas empresas em relação a outras, mas a síntese do processo em si recai sobre as vantagens que as empresas promovem para instigar a concorrência.

No que tange às cadeias de valores identificadas pelas várias atividades diferenciadoras, do ponto de vista tecnológico e econômico, a empresa desempenha um papel relevante na elaboração de estratégias que permitem sustentar a vantagem competitiva no mercado. Porter (1999) envereda-se nessa análise afirmando que a cadeia de valores agrega à empresa a noção de organização das suas atividades de relevância estratégica. Entretanto, é importante destacar que a cadeia de valor é um fator fundamental da vantagem competitiva de uma empresa, pois se identifica como uma fonte de escopo

\footnotetext{
${ }^{70}$ A cadeia de valor é um sistema de atividades interdependentes, mas conectados por elos (PORTER, 1999).
} 
competitivo, uma vez que são os fluxos das atividades, ou seja, a logística ${ }^{71}$ das empresas que as diferenciam no mercado. Desta forma, a cadeia de valor não apenas pode agregar um conhecimento potencial de organização logística, mas também pode projetar-se como uma vantagem competitiva.

Essa organização logística processa-se como um fator de diferenciação que está conectada aos demais elos de desempenho e desenvolvimento da empresa. Assim, destacase que uma empresa constitui uma reunião de atividades, desde a gestão interna até o produto final, ou seja, desde o planejamento do que será oferecido até a venda de determinado produto ao cliente, o que, nesse caso, pode ser entendido no processo de comercialização das passagens aéreas e nas operações de bordo aos usuários. Tal reunião de atividades tem como fim único projetar, produzir, comercializar, entregar e sustentar aquilo que é consumido. É nesse ínterim que se encontra a cadeia de valor, que é responsável por gerir as atividades de uma empresa, isto é, sua evolução histórica, suas estratégias e o seu método de implementar suas estratégias de mercado. No caso dos transportes, a cadeia de valores contribui para o entendimento da logística das empresas.

De forma mais empírica, procura-se tratar os componentes das vantagens competitivas correlacionando-as à atuação das empresas aéreas que operam voos regulares no interior do Estado de São Paulo. Com isso, temos que as empresas, embora produzam cadeias de valor de um mesmo ramo, são muito diferenciadas. As diferenças entre cadeias de valor concorrentes são uma fonte básica de vantagem competitiva.

É no interior das empresas, ou seja, no processo de gestão, de planejamento setorial, de organização estrutural de cada setor que se encontra a cadeia de valor diferenciada. Exemplos de cadeia de valor diferenciada são inúmeros e podem ser mais visíveis nas grandes empresas aéreas, tais como a TAM e a Gol, que modelam suas atividades baseadas no mercado de maior valor agregado, isto é, nas rotas de maior densidade de fluxos, como nos voos nacionais e internacionais. No entanto, no segmento regional o que se observa é a eliminação das empresas de pequeno e médio porte ou, ainda, acordos comerciais de reciprocidade com estas mesmas empresas, na tentativa de incorporar a estratégia de barreira à entrada.

\footnotetext{
${ }^{71}$ A logística compreende as estratégias, a gestão e o planejamento em transportes. Assim, logística não é um modal ou um conjunto articulado de modais, mas o planejamento de viabilização e utilização (rotas, velocidade, armazenagem, intermodalidade, desburocratização, comunicação e outros) para melhor atender as demandas pré-existentes e existentes (SILVEIRA, 2009a).
} 
Nesse âmbito, Pons e Reynes (2004) ${ }^{72}$ asseveram que:

Las compañías aéreas se han embarcado en procesos de concentración empresarial, mediante la fusión corporativa, adquisición o alianzas entre ellas, tendentes a racionalizar y reorganizar los servicios y intercambiar áreas de influencia en los mercados (PONS; REYNES, 2004, p. 184).

A atual tendência mundial de flexibilização da desregulamentação no serviço de transporte aéreo de passageiros ${ }^{73}$ gerou, primeiramente, um processo de concentração, fusões e, posteriormente, processos de aquisição ${ }^{74}$, cooperação e acordos de reciprocidade entre as companhias, disposição observada no cenário mundial. Para Coutinho, (1994) a emergência de novas formas de concorrência entre as empresas, por meio da proliferação de redes de cooperação, alianças tecnológicas e outras alianças competitivas, sintetizam perfeitamente a dimensão sistêmica da competitividade das empresas brasileiras.

Um dos principais acordos comerciais no mercado aéreo é o sistema de codeshare e o sistema de wet-lease $e^{75}$. O primeiro refere-se a um acordo entre empresas na disponibilização recíproca de aeronaves. Já o segundo consiste num acordo de disponibilização recíproca de assentos (RAGAZZO, 2006). Nesses mesmos modelos, encontramos, ainda, o sistema Special Prorate Agreement ${ }^{76}$, que permite ao usuário comprar uma única passagem aérea e voar do Brasil para diversos destinos em todo o mundo a preços mais competitivos do que o passageiro obteria caso adquirisse os bilhetes separadamente. Este sistema permite a cada empresa aumentar o número de cidades servidas pelo modal, consubstanciando uma estratégia de mercado na dinâmica empresarial.

Esse sistema já é utilizado em Ribeirão Preto, com as empresas TAM e Passaredo e, consubstancia-se na principal estratégia empresarial do segmento regional.

\footnotetext{
${ }^{72}$ Pons e Reynes (2004) realizaram um trabalho sobre transporte aéreo na Europa, seus estudos mostram que a empresas aéreas européias apresentam uma aparente semelhança em sua organização com as empresas aéreas brasileiras.

${ }^{73}$ Esta tendência de flexibilização do setor aéreo é verificada, sobretudo nos Estados Unidos, Canadá e México.

${ }^{74}$ Neste momento, é importante destacar que essa tendência é inerente à especialidade produtiva da concorrência nas atuais empresas aéreas, ou seja, de aquisição de outras empresas, acarretando no que Porter (1999) define no conceito de Gestão de Portfólio. Para o autor, essa é mais uma estratégia que consiste na diversificação das atividades de uma empresa que está solidamente arregimentada. Tal estratégia consiste na criação de valor e diferenciação da empresa e favorece uma amplitude de negócios que, no caso das empresas aéreas, oferece geograficamente um maior poder de atuação no mercado aéreo.

${ }^{75}$ Entre as empresas que possuem acordos de codeshare e wet-lease com demais empresas, a que tem um maior destaque nessa cadeia de valor diferenciada é a TAM. A empresa possui acordos de reciprocidade com Air Canadá, Air Canadá, BMI British Midland, LAN Airlines, Lufthansa, NHT Linhas Aéreas, Pluna, TAP Portugal, Trip Linhas Aéreas e United Airlines.

${ }^{76}$ Esse sistema é realizado pela empresa TAM Linhas Aéreas, que possui acordos com 64 empresas aéreas em todo mundo.
} 
Essa estratégia implica em interesses de ambas no mercado aéreo de Ribeirão Preto, da TAM para enfatizar sua marca na cidade gerando com isso mais prestígio, já que essa linha permite preencher seus voos nacionais e internacionais com origem em Ribeirão Preto, atraindo os usuários que poderiam utilizar a Passaredo nas ligações até São Paulo e de lá utilizar outra empresa até o seu destino final. A partir dessa estratégia de cooperação a TAM já compromete o usuário a utilizar a empresa até seu último destino. Já a Passaredo mantém-se no mercado vislumbrando melhores acordos com uma empresa aérea que já é consolidada no mercado, isso traz da mesma forma, prestígio para a empresa e favorece sua atuação nesse segmento, pois possui uma demanda garantida, já que os usuários terão como única opção a Passaredo.

Quando se trata da diferenciação do produto, o fator de maior relevância é a ocorrência dos preços. A diferenciação do produto para o consumidor é qualificada e, principalmente, quantificada pelo preço cobrado nas empresas que oferecem o serviço. Losekann e Gutierrez (2002), ao analisarem a homogeneidade do produto, neste caso, o preço da passagem aérea, destacam que os consumidores consideram os produtos idênticos (isto é, substitutos perfeitos). No entanto, a ocorrência da qualidade do serviço prestado é também um fator que influência na opção do produto.

Ao tomar tal elucidação, é necessário atentar para as diferenciações/diversificações do que e de como as empresas oferecem seus produtos. Por exemplo, no modelo de concorrência perfeita, no qual os produtos são idênticos, a premissa não retrata, de fato, a realidade do mercado aéreo. Os valores cobrados pelas empresas aéreas tornam-se independentes, quando o usuário tem a disponibilidade de pagar o valor cobrado em razão de suas prioridades, necessidades e preferências subjetivas distintas. $\mathrm{O}$ poder de mercado de uma empresa pode muito bem caracterizar a preferência dos usuários.

Dentro desse contexto de análise de diferenciações e diversificações das companhias, destacamos uma estratégia de mercado utilizada pela TAM Linhas Aéreas. A empresa trabalha com a diferenciação de classes, subdividas em suas aeronaves nas classes executiva e econômica. Tal diferenciação faz parte da estrutura organizacional da empresa, que se enquadra no conceito tradicional de operações aéreas, ofertando voos com padrões diversificados, atendendo à opção do usuário.

Além da diferenciação de classes nas aeronaves, a empresa TAM opta, ainda, pela diferenciação das tarifas. A empresa discrimina as opções de voos, adequando-as ao perfil do usuário. Assim, descreve cinco classes de voos: Promo, Light, Flex, Max e Top. 
Essas definições de voos são diferenciadas, sobretudo, em relação ao preço da passagem cobrada. Exemplificamos tal fato citando os preços cobrados no mercado aéreo paulista.

Uma passagem aérea da empresa TAM no trecho entre Ribeirão Preto e São Paulo, no sistema de diferenciação por tarifa, pode ter uma variação de até R \$ 450, 00. Já no trecho entre São José do Rio Preto e São Paulo, a variação do preço da passagem pode chegar a $\mathrm{R} \$ 489,00^{77}$. Desta forma, é o usuário que opta pela classe que deseja viajar, pagando por isso um preço maior ou menor de acordo com a classe de voos.

Após a aquisição da empresa VARIG Brasil, a Gol passou a utilizar-se da diferenciação de classes. Na tentativa de atender um público diferenciado, mas também como forma de adequar a demanda aos padrões da antiga VARIG, que já possuía fisicamente esta diferenciação de classes em seus aviões, que a empresa Gol passou a oferecer, atualmente, a classe Comfort.

De acordo com a Gol, essa diferenciação baseia-se numa classe de maior conforto, mais prioridade e, portanto, de maior preço. Ainda baseado na diferenciação por tarifa, a empresa Gol oferece quatro distinções de tarifas: Promocional, Programada, Flexível e Livre. O sistema de tarifas da empresa Gol, semelhante ao descrito pela TAM, também se distingue no preço das passagens aéreas, que atingem diferenças consideráveis: no percurso de Presidente Prudente a São Paulo, por exemplo, o valor da passagem por diferenciação de tarifa pode chegar a $\mathrm{R} \$ 381,00$ em períodos promocionais ${ }^{78}$.

Outra vantagem competitiva que faz com que as grandes empresas continuem a duopolizar o mercado da aviação comercial regional do Estado de São Paulo circunscrevese nos programas de milhagem. A TAM dispõe do programa TAM Fidelidade ${ }^{79}$ e, a Gol, do programa Smiles ${ }^{80}$. Ambos os programas computam pontos de viagens realizadas pelos usuários ou a compra e utilização de produtos da empresa e de suas parceiras, como hotéis, restaurantes, lojas virtuais, locadoras de automóveis, cartão de crédito, etc. A somatória desses pontos dão direito a voos pelas empresas e por suas associadas, além de vantagens como balcões de check in exclusivos, maior franquia de bagagem e acesso às salas Vip em aeroportos.

\footnotetext{
${ }^{77}$ Informações obtidas em 12/10/2009, disponíveis em www.tam.com.br

${ }^{78}$ Informações obtidas em 12/10/2009, disponível em www.voegol.com.br

${ }^{79}$ A empresa TAM Linhas Aéreas possui 4,5 milhões de associados no Programa TAM Fidelidade.

${ }^{80}$ A empresa Gol Linhas Aéreas Inteligentes conta com uma carteira de 5,9 milhões de participantes no Programa Smiles.
} 
As demais empresas - Pantanal e Passaredo - apresentam aeronaves de pequeno porte, sem diferenciação de classes e/ou diferenciação por tarifas ${ }^{81}$, e ainda não dispõem de programas de milhagens. No entanto, as aeronaves destas empresas enquadram-se na melhor escolha de equipamentos, uma vez que correspondem fisicamente ao segmento regional.

Contudo, a disponibilização de aeronaves com espaço para diferenciação de classes e tarifas permite a expansão destes programas que estimulam o usuário na utilização de determinadas empresas e incitam as pequenas e médias à fusão e cooperação com as de maior porte, que possuem um maior market-share ${ }^{82}$. A partir dos acordos comerciais com as grandes empresas, há uma perspectiva de vislumbrar um mercado e participar das ações estratégicas das já capitalizadas.

Ainda sobre a venda de passagens, a Gol implementou um novo sistema, o New Skies, desenvolvido pela empresa norte-americana Navitaire. A plataforma substituiu o sistema Open Skies e melhorou o desempenho e a qualidade no atendimento aos clientes, além de maximizar os canais de distribuição da companhia, com ênfase nas vendas pelo $e$ commerce. O New Skies faz parte da nova geração de sistemas de distribuição e venda e foi especialmente desenvolvido para empresas aéreas em rápida expansão e que operam no modelo de baixo custo.

Tal iniciativa gerou uma vantagem competitiva para a Gol, que passou a disponibilizar de um sistema de atendimento mais rápido e eficiente do que as outras companhias. Essa estratégia competitiva tem cooperado para uma potencial diferenciação na cadeia de valor da empresa, como verificado em Presidente Prudente. Com a ferramenta, o site da companhia oferece mais facilidades para os clientes, inclusive uma interface de venda de bilhetes mais funcional.

$\mathrm{Na}$ análise sobre a cadeia de valor e a diferenciação do produto, pode-se observar com maior destaque o papel desenvolvido pelas grandes empresas, já que estas são detentoras de um market share predominante. A funcionalidade das empresas Gol e TAM, as major players do mercado regional atraem o usuário do modal aéreo que, além de dispor de um valor mais acessível nas passagens aéreas, facilidade de crédito na aquisição

\footnotetext{
${ }^{81}$ Quando comparamos os preços das passagens aéreas é possível observar a considerável variação de preço cobrada pelas empresas. Por exemplo, a diferença do preço de uma passagem aérea com o mesmo trajeto pode ter uma diferenciação de até 146,00 entre as empresas Pantanal e Gol (Informações obtidas em 12/10/2009, disponíveis em www.voegol.com.br e www.voepantanal.com.br).

${ }^{82}$ Market-share: conceito comumente utilizado no mercado aéreo para definir o poder de mercado que as empresas possuem. "A expressão em inglês significa 'participação no mercado', isto é, a fração do mercado controlado por uma empresa ou participação no mercado nas vendas de um determinado produto (SANDRONI, 2005, p. 514)".
} 
das passagens e programas de milhagem de voos, possui ao seu alcance aeronaves modernas, um sistema de compra e check in mais modernos e tecnicamente mais eficazes, alteração de voos on line, parcelamento do preço das passagens aos consumidores mais sensíveis ao preço etc. Assim, a agregação desses elementos estimula a preferência dos consumidores e implica em desvantagens para as pequenas e médias empresas que não dispõem dessas tecnologias.

A constante inovação das empresas, sobretudo no que diz respeito às inovações tecnológicas, é outro vetor de fundamental atração dos usuários do modal. Hasenclever e Tigre (2002) investigam a estrutura do mercado e as inovações tomando como ponto central da discussão o caráter tecnológico e organizacional das empresas, como forma de fazer frente à concorrência e a acumulação de riquezas.

Ainda nessa discussão, Silveira (2009) aponta que o potencial demonstrado pelas inovações proporcionou uma reestruturação territorial e organizacional das empresas. Para Porter (1989), as transformações tecnológicas têm poder para influenciar a estrutura de uma empresa e suas vantagens competitivas e, com isso, a estratégia da tecnologia passa a ser um ingrediente essencial num mercado altamente competitivo, como é o aéreo.

Busca-se, assim, contextualizar as estratégias das empresas, numa perspectiva que difere da visão neoclássica sobre a questão. Nessa óptica, nos atemos às descrições de Hasenclever e Tigre (2002) $)^{83}$, para quem as empresas funcionam como um organismo em permanente mutação, que recebe influências do mercado onde atua. Todavia, realiza um processo mútuo, ou seja, as empresas também são capazes de transformar o ambiente de atuação a partir da introdução de suas estratégias, sejam elas de inovações tecnológicas, organizacionais, setoriais, logísticas etc.

Observamos que no mercado aéreo regional do Estado de São Paulo, as cidades interferem na dinâmica das empresas, ou seja, suas ações advêm daquilo que a população local e do seu entorno necessitam, isto é, ligações rápidas com o centro urbano de maior projeção no Estado de São Paulo, a cidade de São Paulo. Assim, notamos que, se por um lado, o mercado influi nas ações estratégicas das empresas, por outro, as empresas articulam-se induzindo a escolha do usuário por determinada companhia, seja por meio de propaganda, preço ou ainda por meio dos acordos de cooperação entre as empresas, que não deixa opção ao usuário a não ser utilizar o que é disponibilizado.

\footnotetext{
${ }^{83}$ Hasenclever e Tigre (2002) partem de uma análise schumpeteriana para contextualizar as empresas e as inovações tecnológicas.
} 
A partir dessas averiguações, constatamos que as empresas caracterizam um importante fator de crescimento do setor. Desta forma, mediante o desenvolvimento e a evolução do transporte aéreo, Pons e Reynes (2004) analisam o setor e os fluxos de passageiros, concluindo que:

La organización espacial, la estructuración de sus redes y la evolución de sus flujos han corrido parejas al desarrollo tecnológico de la aeronáutica, a los específicos niveles de regulación del tráfico, a escala nacional, internacional, así como a las estratégias comerciales de las compañías operadoras (PONS; REYNES, 2004, p. 177).

Nesse sentido, as estratégias das empresas expressam-se como um fator de seleção no mercado. O processo de criação de vantagens competitivas instaura-se num quadro analítico, no qual se observa que a evolução, o crescimento, bem como os rendimentos de uma empresa, se dão mediante a estrutura do mercado. Contudo, quem coordena esse mercado, por um lado, são as empresas, que por meio de suas ações, estratégias, incorporações, fusões e aquisições moldam essa estrutura e, por outro, a sociedade, ou seja, a demanda, que fomenta a estruturação e organização deste mercado.

$\mathrm{Na}$ prática, tem-se que as grandes empresas aéreas que operam voos no Estado de São Paulo possuem uma organização técnica típica da aviação comercial de grande porte. Esse fato faz com que suas ações no mercado nacional e até mesmo no internacional sejam adotadas, também, no mercado regional. Por um lado, esse processo traz ganhos para as cidades que operam voos regionais, pois confere a esses centros urbanos a inserção na rede aérea do país, favorecendo o desenvolvimento econômico e urbano. Por outro lado, estas empresas descaracterizam o papel do segmento regional, uma vez que se impõem de forma que minimizam a concorrência territorial.

Outro importante fator de diferenciação entre as empresas e que repercute potencialmente na imagem destas, bem como das cidades é a atuação na mídia a partir da propaganda e do marketing. Dentro dessa perspectiva, Almeida e Losekann (2002) destacam que:

A propaganda é um instrumento muito utilizado para diferenciação de produtos. O objetivo básico da empresa ao realizar propaganda é influenciar na formação das preferências dos consumidores, aumentando a demanda de seu produto. Portanto, a propaganda é um elemento relevante da estratégia competitiva das empresas (ALMEIDA; LOSEKANN, 2002, p. 449).

Dentro dessa noção, vê-se, ainda, que a propaganda e o marketing têm a função de gerar a interatividade do setor comercial. Isto é, as inovações, sejam elas relacionadas à tecnologia ou à organização logística, são levadas ao consumidor, por meio da propaganda, 
do marketing ${ }^{84}$ e, até mesmo, das informações dos comissários de bordo, que, em seus informes, relatam a modernização da empresa, principalmente quando estas dispõem de aeronaves modernas. As empresas despendem valores consideráveis com propaganda e marketing, conforme Tabela 14.

Tabela 14 - Despesas de comercialização com propaganda e marketing das empresas aéreas que operam no interior do Estado de São Paulo - 2007

\begin{tabular}{l|l}
\hline \multicolumn{1}{c|}{ Empresas } & Valores em milhões \\
\hline TAM Linhas Aéreas & $\mathrm{R} \$ 975,1$ \\
\hline Gol Linhas Aéreas Inteligentes & $\mathrm{R} \$ 414,1$ \\
\hline Passaredo Linhas Aéreas & $\mathrm{R} \$ 200$ \\
\hline Pantanal Linhas Aéreas & Não informado \\
\hline
\end{tabular}

Fonte: Trabalho de campo, 2009; Relatórios Anuais das empresas, 2007

Org.: Camilo Pereira, 2009

Perroux (1969, p. 491), ao considerar a propagação da informação, diz que a "informação circula" e os maiores organismos, os mais poderosos - nesse caso as grandes empresas - detém um poder econômico capaz de informar, mas ao mesmo tempo, de oferecer e manipular a opção pelo seu produto.

Todo o processo de incorporação da estratégia de visualização pela propaganda e pelo marketing é analisado por Porter (1999) mediante a complexidade da "revolução da informação". Para o autor, a tecnologia da informação é capaz de transformar o modo de pensar e de planejar a compra de um produto pelo usuário. A propaganda cumpre o papel de informar e divulgar, mas também de persuadir. Nesse mesmo raciocínio, Almeida e Losekann (2002) asseveram que o principal objetivo da propaganda é proporcionar um aumento das vendas por meio da modificação das preferências dos consumidores e, ainda, tem como intuito aumentar o nível de informação do produto que deseja comercializar. Isso se torna evidente no setor da aviação comercial quando nos defrontamos com o "armamento tecnológico de informação" que as empresas disponibilizam para o usuário do modal.

A propaganda e o marketing têm um papel preponderante nas estratégias comerciais das empresas no Estado de São Paulo, pois funcionam como um dos principais instrumentos de diferenciação no processo de concorrência. Almeida e Losekann (2002, p.

\footnotetext{
${ }^{84}$ As empresas aéreas brasileiras dispõem de um setor de propaganda e marketing por meio de revistas, que são dispostas nos aviões das empresas. Tal estratégia tem como intuito trazer ao usuário informações relativa ao desenvolvimento e crescimento da empresa. Funcionam como um "cartão de visita" da empresa. Nessas revistas, são encontrados os destinos que a empresa oferece aos usuários do transporte aéreo, as palavras do presidente da empresa que, geralmente, trazem as perspectivas de futuro, as inovações, etc.; informes das empresas, como a composição da frota, os endereços de suas lojas, os serviços oferecidos, centrais de reservas, entre outros.
} 
466) enfatizam que o principal objetivo dessa estratégia consubstancia-se em “(...) atuar sobre as preferências dos consumidores em favor de um produto ou uma marca".

O recurso da informação soma-se ainda ao da informatização via conexão que é o grande gerador da propagação das inovações pelas empresas aéreas. O que antes era realizado com a necessidade do usuário deslocar-se até uma agência de viagens ou até o aeroporto, a fim de adquirir uma passagem aérea, hoje se dá por intermédio da compra da mesma pela internet ou pelo celular.

A principal companhia aérea que realiza esse tipo de sistema comercial, baseado em vendas pela e-commerce e pelo celular, é a Gol Linhas Aéreas Inteligentes ${ }^{85}$. Este modelo comercial de sistema de vendas reais e não de reserva, como ocorre nas companhias tradicionais, permitiu a criação de uma vantagem competitiva para a empresa. No caso da compra do bilhete por telefone, a mesma utiliza o sistema 0300, ou seja, o usuário paga o custo de uma ligação local, reduzindo assim os custos da empresa. A Gol possui uma despesa comercial média de $11 \%$ do custo total, enquanto a concorrência gasta em torno de $26 \%$ do custo total com despesas comerciais, emissão de bilhetes, serviços de correspondência etc. (PIZZINATTO et al 2006).

No entanto, a empresa TAM, frente a essa vantagem competitiva da Gol, inseriu-se nesse mercado virtual, como forma de competição direta e reestruturação empresarial, baseada no pragmático nível de informatização mundial, onde praticamente todas as relações comerciais podem ser realizadas pelo e-commerce. Com o plano de buscar mais passageiros, elevando a taxa de ocupação das aeronaves nos voos em horários de baixa demanda, a TAM iniciou novas modalidades de pagamento, que oferecem mais facilidades aos passageiros que adquirem seus bilhetes aéreos diretamente pelo website ou pelo call center. Essas novas formas de venda são realizadas por meio de pagamento em casas lotéricas; pagamento via boleto bancário; débito automático; financiamento com os bancos ABN Real, Banco do Brasil, Bradesco, Caixa Econômica Federal, Itaú e Unibanco.

As estratégias de convergência das empresas que se baseiam, sobretudo, nas tecnologias de informação, permitem a praticidade da compra da passagem aérea, que se tornou mais rápida e mais prática para o usuário. Hoje, o usuário compra sua passagem, agenda seu voo, paga seu bilhete e remete sua agenda aos serviços disponíveis nas páginas das empresas pela internet (auto-atendimento), facilitando o desprendimento da aquisição da passagem, da opção de numeração do assento e da escolha do horário, da classe, da

\footnotetext{
${ }^{85}$ A venda de passagem pela internet é exemplo de uma estratégia de imitação. Hoje, todas as empresas operantes no Estado de São Paulo já utilizam essa estratégia de mercado.
} 
tarifa, da programação da compra (a vista, a prazo, cartão de crédito, cartão de débito, cartão da própria empresa, fatura bancária etc.). Esse tipo de estratégia permite que as empresas reduzam custos de operação na emissão de bilhetes, o que gera um "sobre-lucro" para elas.

A nova tendência da aviação comercial, fundada nas estratégias de empresas estrangeiras $^{86}$ de arrecadar receitas adicionais nos serviços de bordo, é incorporar adaptações de menor custo garantindo lucros às empresas, como a redução dos serviços de alimentação prestados pelas companhias ${ }^{87}$. A eliminação de bilhetes impressos reduz também custos com papel, postagem, tempo de serviço de colaboradores e despesas de processamento.

Outra estratégia utilizada pelas empresas aéreas para a arrecadação orçamentária é a publicidade, ou seja, há a cobrança de espaços publicitários para empresas de outros $\operatorname{ramos}^{88}$, que incluem, por exemplo, a colagem de adesivos comerciais na fuselagem do avião, no interior das aeronaves, nas capas dos assentos das poltronas, além de espaços nas revistas de bordo etc.

Dentre as principais estratégias de propaganda e divulgação da marca da empresa, a mais usual nas cidades com aeroportos regulares do Estado de São Paulo é a propaganda por meio de outdoor. Embora as empresas também se utilizem da mídia televisionada (canais de TV aberta e canais pagos) e escrita (jornais, panfletos etc.), a divulgação em placas modulares em locais de grande visibilidade caracteriza a predominância da ação publicitária das companhias no interior paulista. Tal fato é verificado atualmente na cidade de Presidente Prudente com a entrada da empresa Passaredo, nas cidades de Marília e Bauru para a divulgação da escala de voos realizada por esta empresa, assim como também é usualmente realizado pelas empresas TAM e Gol nas cidades onde operam o transporte aéreo.

O usuário é, por fim, o principal objetivo das ações de inovação das empresas do mercado aéreo. É mediante as opções que os usuários fazem que as empresas aéreas planejam-se, organizam-se e exploram o mercado, pois é o usuário a fonte de lucro das

\footnotetext{
${ }^{86}$ No cenário internacional é comum a cobrança por serviços de bordo, como vendas de bebidas e alimentos e aluguel de aparelhos celulares e laptops. No Brasil, estes serviços ainda não são cobrados; todavia, há uma forte tendência a readequação aos modelos de empresas aéreas de bandeira internacional.

${ }^{87}$ Atualmente, apenas as empresas consideradas tradicionais, como a TAM, utilizam nos serviços de bordos as refeições quentes.

${ }^{88}$ Cabe destacar alguns exemplos de empresas que utilizam os espaços publicitários das empresas aéreas: Companhia Vale do Rio Doce, Vivo Celulares, Hotéis Othon, Baptist Hospital, Hospital HCor, General Motors, Editora Arte, Restaurante Ópera, Restaurante Vento Hagarano, Faculdades Fanorpi, Fundação Getúlio Vargas, Rede Globo de Televisões, Nestlé, Revista Aero Maganize etc.
} 
empresas. Há consumidor para todo tipo de produto, a diferenciação do mesmo baseia-se nesse requisito. Com base nos elementos destacados, as empresas mantêm-se no mercado, sobretudo as de grande porte, que controlam as estratégias em favor de seus interesses e assim regulam e programam suas malhas de fluxos, suas tarifas e a monitoração das empresas entrantes.

Ao investigar as empresas a partir da coerência produtiva, tem-se que ela está "obrigada" a crescer, ou seja, a reinvestir produtivamente os lucros gerados, podendo ser percebida como o locus da acumulação de capital (BRITTO, 2002). No tocante a isso, quando se analisa a coerência produtiva das empresas, a base de investigação empírica torna-se escassa, uma vez que a disponibilidade de informações de custos, lucros e investimentos estratégicos destas são confidenciais, o que implica em especulações. No entanto, nossas fontes de dados, os trabalhos de campo (entrevistas, materiais recolhidos, bibliografia utilizada e consultada) compõem um compêndio daquilo que as empresas planejam, organizam e concretamente realizam.

Dentre as estratégias que conferem a coerência produtiva, é essencial abordar a diversificação e a competência da estratégia. Para Britto (2002), a diversificação contribui para a expansão das empresas.

A diversificação é uma alternativa extremamente interessante para viabilizar o crescimento da empresa, na medida em que lhe permite superar os limites de seus mercados correntes, ao mesmo tempo em que possibilita, através da gestão de um conjunto de diversas atividades, ampliar o "potencial de acumulação" que influencia a dinâmica do crescimento empresarial (BRITTO, 2002, p. 307).

A competência da estratégia está relacionada, principalmente, à capacidade que as empresas têm de sustentar uma vantagem competitiva por um período de tempo que a qualifique no mercado e que a projete potencialmente. Em outras palavras, significa dizer que a competência das estratégias perpassa o fundamento geral do mercado, que é a obtenção de receitas. A manutenção da marca e da imagem da empresa é tão importante quanto à receita que esta obtém. Portanto, as empresas procuram, primeiramente, consolidar sua estrutura de programação de fluxos, mediante promoções, facilitações de vendas etc., com o objetivo de personificar a sua marca. A imagem da marca da empresa é um ativo importante para a consolidação no mercado, uma vez que é por meio de seu "rótulo" que programará suas estratégias de diferenciação mediante a comercialização.

As empresas que conseguem inserir-se num mercado competitivo, como é o aéreo, necessitam inovar constantemente, uma vez que as de grande porte, já capitalizadas, 
possuem estratégias de barreira à entrada (KUPFER, 2002). Tal assertiva propugna o que salientamos anteriormente sobre a duopolização existente no mercado aéreo, que impele a dinâmica econômica e empresarial das pequenas e médias empresas do ramo, induzindo-as aos acordos comerciais com as grandes empresas.

Complementando o potencial das estratégias de mercado, das vantagens competitivas e da capacidade de inovar das empresas, observamos, também, o ambiente tecnológico do setor, no que diz respeito às frotas de aeronaves. Nesse âmbito, focalizamos nossas análises, sobretudo, nas aeronaves utilizadas no mercado aéreo paulista. É notável a discrepância entre os modelos usados (Tabela 15) pelas grandes empresas em comparação com as demais empresas atuantes.

Tabela 15 - Modelos de aeronaves, capacidade e quantidade de aeronaves por empresa - 2008

\begin{tabular}{|c|c|c|c|c|}
\hline Empresas & Fabricante & Modelo & $\begin{array}{c}\text { Capacidade de } \\
\text { assentos }\end{array}$ & $\begin{array}{l}\text { Quantidade } \\
\text { por empresa }\end{array}$ \\
\hline \multirow{8}{*}{ TAM } & Airbus & A340 & 267 & 2 \\
\hline & Airbus & A330 & 225 & 12 \\
\hline & Airbus & A321 & 220 & 3 \\
\hline & Airbus & A $320 *$ & 162 & 70 \\
\hline & Airbus & A319* & 132 & 15 \\
\hline & Fokker & FK10 & 108 & 10 \\
\hline & Douglas & MD11 & 285 & 3 \\
\hline & \multicolumn{4}{|c|}{ Total de aeronaves da TAM: 115} \\
\hline \multirow{5}{*}{ Gol } & Boeing & $\mathrm{B} 737 / 300^{*}$ & 141 & 11 \\
\hline & Boeing & B737/700 NG & 144 & 38 \\
\hline & Boeing & B737/800 NG & 184 & 20 \\
\hline & Boeing & $\begin{array}{c}\text { B737/800 NG } \\
\text { SFP }\end{array}$ & 189 & 35 \\
\hline & \multicolumn{4}{|c|}{ Total de aeronaves da Gol: 104} \\
\hline \multirow{3}{*}{ Passaredo } & Embraer & ERJ $145^{*}$ & 50 & 4 \\
\hline & Embraer & ERJ120* & 30 & 6 \\
\hline & \multicolumn{4}{|c|}{ Total de aeronaves da Passaredo: 10} \\
\hline \multirow{2}{*}{ Pantanal } & Aero Spatiale & ATR $42 / 320 *$ & 45 & 6 \\
\hline & \multicolumn{4}{|c|}{ Total de aeronaves da Pantanal: 6} \\
\hline
\end{tabular}

(*) Aeronaves utilizadas na aviação regional no interior do Estado de São Paulo

Fonte: Anuários Estatísticos, (vários anos); Empresas aéreas, 2009

Org.: Camilo Pereira, 2009

Nesta análise, é importante ressaltar que os modelos utilizados em cada segmento são determinados pelas próprias empresas. Embora a demanda pela aviação regional no Estado de São Paulo possua uma baixa densidade de tráfego/dia, sendo mais adequados os modelos que possuem um número reduzido de assentos, que, 
consequentemente, possuem um custo operacional mais baixo, as grandes empresas utilizam aeronaves com capacidade superior a 100 passageiros.

A TAM utiliza nas rotas entre Ribeirão Preto e São Paulo, e entre Ribeirão Preto e São José do Rio Preto, os modelos A319 e A320, aeronaves que apresentam um custo operacional elevado e, portanto, incompatível com a aviação regional. No entanto, os modelos são totalmente utilizados em tais rotas, devido ao fato da empresa possuir uma demanda compatível com a oferta disponibilizada, ou seja, se utilizar aeronaves com capacidade inferior, a empresa deixa passageiros sem voos pela TAM. Todavia, cabe destacar que a mesma é carente em equipamentos com menor capacidade de assentos, pois concentra suas operações em fluxos de alta densidade de passageiros.

A empresa Gol dispõe de aeronaves com capacidade para 141 passageiros nos trechos entre Presidente Prudente e São Paulo. Este modelo também possui uma capacidade operacional elevada para a aviação regional, pois as empresas de grande porte, em razão dos aviões que elas possuem, por exemplo, o modelo B737/300, é antieconômico para esse segmento, pois voar menos de uma hora com este modelo traz um custo operacional alto para empresas de grande porte.

Já a Passaredo está crescendo com o modelo E120 turbo-hélice de fabricação da EMBRAER. O modelo é apropriado para esse tipo de rota, porém possui um limitador, que é a capacidade de passageiros reduzida (30 lugares). No ano de 2009, a empresa adquiriu mais quatro aeronaves - também EMBRAER ERJ145, jato com capacidade para 50 pessoas. A empresa tem investido na compra de aeronaves como forma de garantir a expansão de suas linhas ${ }^{89}$ com origem em Ribeirão Preto. Os investimentos na aquisição das aeronaves relevaram custos de US\$ 75 milhões, parte em leasing ${ }^{90}$ (arrendamento mercantil) e parte em contratos de manutenção e treinamento com a Embraer.

A empresa Pantanal utiliza um modelo que atende positivamente ao mercado da aviação regional (o modelo ATR42), que é um avião maior, mas ainda com características de aviação regional, com custo operacional mais baixo e capacidade para 42

\footnotetext{
${ }^{89}$ Mediante entrevista realizada com o Diretor Comercial e Planejamento da Passaredo Linhas Aéreas, Sr. Ricardo Cagno, novas linhas estão sendo programadas pela empresa, que pretende expandir a aviação comercial, tendo a cidade de Ribeirão Preto como o principal hub regional do Estado de São Paulo. A mais nova linha da empresa tem origem em Ribeirão Preto, seguindo para Goiânia, Cuiabá e, posteriormente, para Alta Floresta. Para empresa, essa é a principal estratégia: expandir a aviação regional a partir de Ribeirão Preto.

${ }^{90}$ Leasing: “operação financeira entre uma empresa proprietária de determinados bens (veículos, máquinas etc.) e uma pessoas jurídica, que usufrui desses bens contra o pagamento de prestações. Os contratos são sempre com tempo determinado, ao fim do qual a empresa arrendatária tem opção de compra do bem (SANDRONI, 2005, p. 469)."
} 
e 50 lugares. No entanto, o mercado que a Pantanal atende é servido pela Gol e agora pela Passaredo, empresas que além de possuir aeronaves mais modernas e velozes, possui tarifas mais acessíveis, em razão da concorrência potencial. Tal fato tem gerado prejuízos à Pantanal.

O regime de concorrência entre as empresas é formalizado, principalmente, pelos equipamentos que estas dispõem. Isso faz com que empresas como a TAM e a Gol, que, embora possuam aeronaves incompatíveis com a aviação regional, arrecadem mais do que as pequenas e médias empresas. Estas já estão capitalizadas e realizam uma concorrência potencial na qual as empresas de pequeno e médio porte não suportam. Tal fato é resultado da liberalização do mercado que aumentou drasticamente a oferta de companhias que realizavam as mesmas rotas sem um planejamento prévio, ampliando o setor à dimensão e à configuração do mercado, que é controlado pelas grandes empresas. Com isso, a concorrência impôs-se de forma indiscriminada, acentuando práticas de dumping ${ }^{91}$ no setor da aviação comercial.

A partir desse enfoque, observamos que o resultado da desregulamentação é reflexo das condições deficitárias que o transporte aéreo apresenta atualmente. Após o início do processo de desregulamentação, as grandes empresas concentraram suas operações nos trechos mais lucrativos do mercado aéreo. Tal intento culminou na adoção do sistema hub-and-spoke ${ }^{92}$.

O sistema hub-and-spoke de operações, que significa "centro e raio" ou "rede em estrela", é um modelo baseado em um sistema de tráfego no qual as destinações periféricas são conectadas a um aeroporto central, que concentra e redistribui os fluxos de carga e passageiros (ALMEIDA, 2004). Soutelino (2006), ao desmistificar o conceito em seu sentido mais genérico, ressalta que esse tipo de operação, iniciada nos Estados Unidos, teve como intuito impulsionar a concorrência, diminuir as operações point-to-point ${ }^{93}$ e, consequentemente, aumentar a malha aérea das empresas.

Em síntese, as operações point-to-point e hub-and-spoke podem ser definidas a partir de suas ligações, sendo comumente apresentadas como:

\footnotetext{
91 Dumping: prática comercial que consiste em vender produtos a preços inferiores aos custos, com a finalidade de eliminar concorrentes e/ou ganhar maiores "fatias" do mercado (SANDRONI, 2005, p.267).

92 A estratégia hub-and-spoke consiste em concentrar os voos de curta distância em aeroportos centrais, denominados hubs e, a partir deles, alimentar outras localidades. Tal sistema de rede consolidada procura tirar proveito da economia de escalas das aeronaves maiores, reduzindo o número de voos que possuem baixas demandas, o que permite tornar adequadas operações em aeroportos eslotados (BNDES, 2001).

${ }^{93}$ Voos diretos sem conexão e/ou escala.
} 
Figura 1 - Operações Point-to-Point

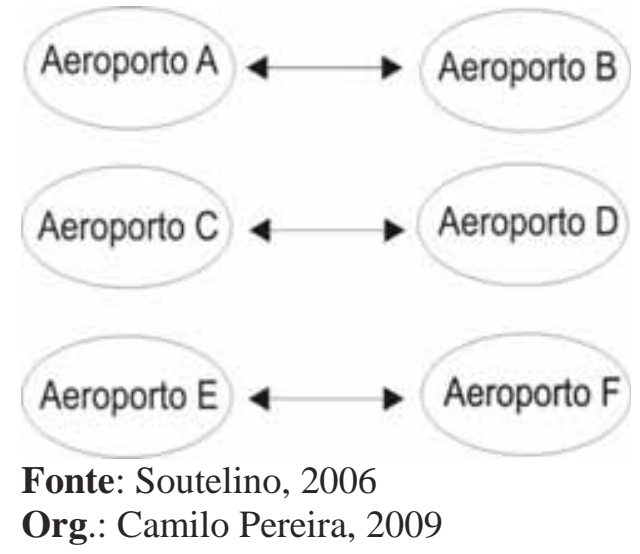

Figura 2 - Operações Hub-and-Spoke

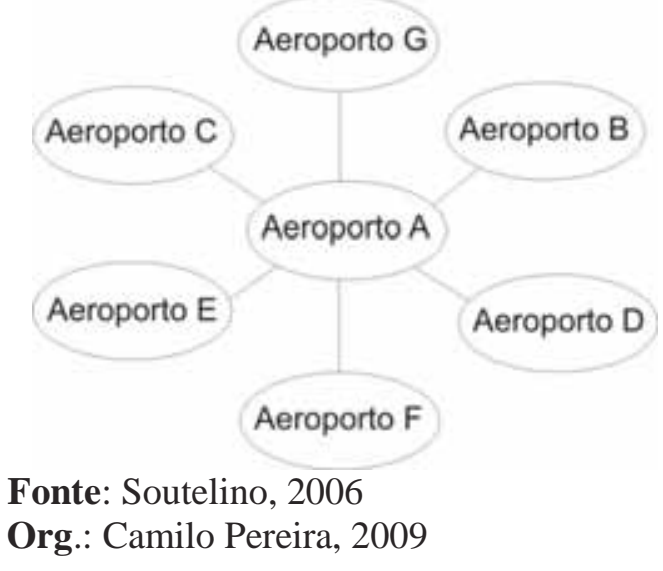

A partir das operações apresentadas, consideramos que a otimização do modelo hub-and-spoke configura uma opção coerente para o transporte aéreo regional, numa perspectiva de descongestionar os grandes hubs do setor no Estado de São Paulo. Todavia, o início desse tipo de operação confirmou-se mediante a redução das ligações regionais no Brasil. Almeida (2004) assevera que:

O sistema permite otimizar o uso da capacidade das aeronaves, pois reduz a quantidade de trajetos regionais, e, além disso, assegura ganhos de escala nos grandes aeroportos (hubs). Ele permitiu a redução da proporção de lugares vazios nos voos e, por consequência, o aumento da rentabilidade. Empresas menores, operando em escala regional, frequentemente subsidiárias de grandes firmas, passaram a atender as linhas secundárias abandonadas pelas maiores companhias. Os consumidores, embora tenham se beneficiado pela maior frequência de voos entre os grandes aeroportos e pela redução de tarifas que se seguiu à guerra de preços nas ligações entre os "hubs", perderam em qualidade de serviço, tendo, inclusive, de se submeter a um número maior de conexões com troca de aeronaves (ALMEIDA, 2004, p. 109).

Nessa concepção, enfatizamos que o processamento do sistema hub and spoke atualmente ganha um novo relevo, ou seja, a saturação dos principais hubs nacionais como Congonhas e Guarulhos, tem favorecido a constituição de uma nova concepção para este modelo, em que os aeroportos do interior configuram-se como potenciais no deslocamento de voos com conexão e/ou escalas no Estado de São Paulo.

Ao trazer essa discussão para o âmbito da Geografia, é importante destacar que as operações hub-and-spoke permitem a ampliação das interações espaciais de caráter regional, uma vez que suas linhas favorecem as ligações com aeroportos não eslotados. Nessas condições, estes aeroportos são aqueles que apresentam potencial para geração de tráfego, mas que não estão congestionados, ou seja, os aeroportos regionais do interior paulista identificam-se nessa categoria e são alternativas de um desenvolvimento equilibrado dos aeroportos paulistas. 
A frequência de voos nos aeroportos regionais, bem como a movimentação aérea recente, tem estimulado o crescimento do transporte aéreo no interior paulista. Tais fatores ainda competem para a formação de uma melhor e mais adequada malha aeroviária, possibilitando, com isso, a exclusão de gargalos geradores da atual crise sistêmica do transporte aéreo brasileiro. O modelo hub-and-spoke poderia, ainda, ser utilizado para fomentar as ligações aéreas dos aeroportos regionais com destinos para outros Estados, integrando regionalmente o país. Os voos com destino final nos principais hubs do país aumentam a ineficácia do planejamento aéreo brasileiro. A constituição de alguns pontos estratégicos no Estado de São Paulo pode garantir uma possibilidade de dispersão de voos que hoje estão concentrados, principalmente, no Aeroporto de Congonhas.

No entanto, é importante destacar que uma combinação de elementos implica na defasagem do setor aéreo brasileiro e, por conseguinte, do Estado de São Paulo, o que impede a estruturação de um modelo de operações como o hub-and-spoke. Assim, destacase que essa abordagem permite incluir algumas ressalvas necessárias e que são fatores latentes para a eficácia da estruturação do transporte aéreo no Estado:

i) a precariedade da infraestrutura aeroportuária;

ii) a incoerência do planejamento público e;

iii) a ausência de estímulo ao transporte aéreo regional.

Nessa temática, sinalizamos a escolha dos principais hubs no Estado de São Paulo. O aeroporto de Ribeirão Preto constitui o principal ponto de conexão do setor aéreo paulista, primeiro pela sua capacidade de geração de tráfego e, segundo, pela combinação da demanda econômica e geográfica da região, que favorecem a posição de destaque de Ribeirão Preto como o principal hub secundário do Estado de São Paulo.

O sistema hub-and-spoke constitui desta forma, uma estratégia que pode ser utilizada pelas empresas no transporte aéreo. No mercado aéreo paulista, a principal empresa que realiza esse tipo de operação é a AZUL Linhas Aéreas Brasileiras. A nova companhia concentra rotas entre cidades com aeroportos de porte médio, que ainda não estão eslotados. Com essa estratégia, pretendem criar outros hubs-and-spoke no sistema aéreo brasileiro, no intuito de não arriscar suas operações e fugir dos riscos de "apagões

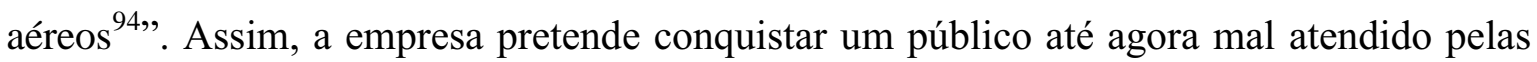
principais concorrentes, como a TAM e Gol. A principal estratégia da empresa é atender às

\footnotetext{
94 Quando trazemos à discussão a expressão "apagão aéreo" referimo-nos a crise infraestrutural do setor de transporte aéreo no Brasil.
} 
diversas localidades com voos diários sem conexão e/ou escala nos aeroportos centrais do país.

As iniciativas da empresa procuram estimular a maior utilização do modal aéreo no Brasil. Nesse âmbito, é importante destacar que a empresa AZUL conta com capital estrangeiro e, consequentemente, com um potencial de crescimento que pode desestruturar o duopólio existente no Brasil, organizado pelas empresas TAM e Gol.

As vantagens do sistema hub-and-spoke são preconizadas por Soutelino (2006), que as explica a partir do poder de barganha que as empresas adquirem. No caso específico do aeroporto de Ribeirão Preto, a empresa Passaredo possui uma vantagem competitiva, que é a ausência de concorrência nesse $h u b$. Para o autor, o poder de barganha que a empresa tem é superior às principais estratégias realizadas no mercado da aviação comercial:

Além do alto poder de barganha mediante a concorrência, o "hub" proporciona outras vantagens como: maior número de voos diretos, facilidade de transferência de voos, curto tempo de conexão para voos de pequenas distâncias, maximizar as rotas de maiores demandas, coordenar o tráfego das conexões, pequena taxa de bagagens avariadas ou extraviadas, e oferecer ao mercado local mais opções de voos e rotas (SOUTELINO, 2006, p. 8).

Desse modo, o sistema hub-and-spoke pode configurar uma estratégia potencial para as companhias regionais, consequentemente estimula a concorrência territorial, e ainda pode gerar um elemento norteador para o colapso dos complexos aeroportuários do Estado de São Paulo ${ }^{95}$.

A partir dessa abordagem sobre as estratégias de mercado no setor de transporte aéreo, é possível endossar nossa análise sobre a atuação das empresas, bem como acentuar a prática da ação das grandes empresas, que mediante uma concorrência potencial extingue empresas que não possuem vantagens competitivas que as consolidem no mercado.

Desta forma, o setor de transporte aéreo regional paulista configura um mercado potencial para a aviação comercial, pois engendra uma mobilidade permanente que satisfaz as expectativas das empresas. A questão principal, no entanto, é caracterizar quais as melhores estratégias para a dinâmica do mercado aéreo regional, sem que, para

\footnotetext{
${ }^{95}$ Salientamos que o sistema hub-and-spoke representa um sistema de operações que possui externalidades negativas, do ponto de vista do congestionamento de hubs. Todavia, essa estratégia pode ser utilizada em aeroportos regionais em menores graus de saliência, ou seja, mediante um projeto de escolhas de hubs secundários que conduzam a eficiência do setor e não a ampliação do congestionamento aeroportuário.
} 
isso, seja imputada ao usuário a ausência de opções de empresas, que mediante acordos comerciais, irrompem o crescimento e o desenvolvimento do segmento regional.

\subsection{O duopólio no mercado aéreo paulista: concentração ruinosa ou estratégia coordenada?}

O mercado da aviação comercial no Brasil possui uma estrutura totalmente coerciva, na qual as condições de permanência das empresas instalam-se voluntariamente, em razão da concentração e da duopolização das grandes empresas aéreas, TAM e Gol.

Para Melo (2002), a concorrência representa o extremo de atomização e

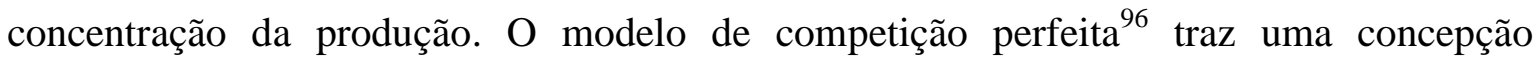
custo/preço que engloba a concorrência de forma geral, como se ela estivesse restrita apenas a esse fator. Assim, associamos o desenvolvimento do setor e a ação e reação das empresas aéreas referindo-nos à concentração existente nesse mercado, que indica o comportamento concentrador como padrão de competição. No entanto, procuramos avançar no sentido de sinalizar para a emblemática situação que ocorre na aviação comercial brasileira tipicamente regional, ou seja, o processo de duopolização que favorece não apenas as grandes, mas inquestionável e indiretamente, as pequenas e médias empresas do ramo.

A postura adotada pelas companhias surpreende do ponto de vista da concorrência direta que, em tese, permitia compreender o princípio da competição. Todavia, o que assistimos atualmente é uma coordenação entre as diversas empresas, no que diz respeito às formações de alianças estratégicas e à atuação destas empresas no mercado de transporte aéreo, tanto no segmento regional, como no nacional e, também, no internacional. Este fato descaracteriza o papel da competição territorial e, ainda, desfavorece as oportunidades de opção do usuário, que se vê coagido a voar por determinadas empresas. É nesse contexto de análise que a ausência da atuação do Estado, mediante as agências reguladoras, tem implicado no desencontro entre o desenvolvimento econômico regional e a atuação das empresas.

Baseados nessa postura do mercado aéreo paulista, atentamos para o que Britto (2002) diz sobre as alianças estratégicas, que conotam para a lógica de integração da

\footnotetext{
${ }^{96}$ As deficiências teóricas das abordagens sobre a competitividade são ainda agravadas pelo fato de que, na maior parte dos casos, seus fundamentos de análise se originam nos princípios da concorrência perfeita, limitando a análise aos fatores relacionados a custos/preços. Essa limitação é tanto mais grave quando se reconhece que, na atualidade, a competitividade é fortemente dependente dos chamados fatores não-preço, isto é, atributos associados à qualidade, à flexibilidade, a prazos de entrega e a conteúdo tecnológico dos produtos, dentre outros (KUPFER, 1996).
} 
concorrência. Para o autor, a coordenação dessas alianças estratégicas entre empresas de diferentes estruturas tendem a privilegiar, numa primeira etapa, arranjos pré-competitivos que facilitam a introdução de inovações no mercado, sobretudo no aéreo, que caracteristicamente sobrevive da capacidade inovativa das companhias. Posteriormente, a montagem de uma relação interativa entre as empresas é capaz de impulsionar o aumento da eficiência operacional. Nesse sentido, "estas alianças compreendem um balanceamento entre princípios de cooperação e competição" (BRITTO, 2002, p. 353).

Para Kupfer (1992), a noção de competitividade, portanto, não pode prescindir de fundamentos microeconômicos genéricos, que sejam pertinentes com suas particularidades enquanto objeto analítico. Esses fundamentos, por sua vez, são demarcados pela dinâmica do processo de concorrência, em particular, pela interação entre as condições estruturais que os direcionam e as condutas inovativas das empresas que os transformam. Diante dessa concepção, inserimos uma discussão que permeia os modelos tradicionais de concorrência e que vinculam a modelagem do funcionamento do mercado. Chamamos a atenção para a ênfase dada ao caráter da concorrência potencial, a qual é definida pelo autor como a competição por lucros, por market share entre empresas já estabelecidas e aquelas empresas entrantes, isto é, as companhias iniciantes e, todavia, potenciais.

A utilização do termo "concorrência potencial" apresenta-se adequada ao exame realizado nesta pesquisa, uma vez que caracteriza o perfil estrutural do mercado aéreo, que contempla, entre outros elementos, a noção de competitividade e cooperação. Nesse contexto, Kupfer (2002) define os elementos básicos que envolvem a concorrência potencial, descrevendo a tipologia das empresas, assim como todo o processo de barreira à entrada. Nessa perspectiva destacamos ${ }^{97}$ :

Empresas estabelecidas: são aquelas que já atuam no mercado. Comumente, as empresas estabelecidas coordenam-se com o objetivo de limitar a entrada de novas empresas. As empresas estabelecidas já estão capitalizadas e recorrem às alianças estratégicas com as pequenas e médias empresas a fim de intensificar sua atuação. Todavia, cabe destacar que, mesmo consolidadas, precedem de estratégias e vantagens competitivas que as qualifiquem no mercado e que as façam prosperar;

\footnotetext{
${ }^{97}$ A identificação e caracterização das empresas em "estabelecidas e entrantes" concernem à estruturação realizada por Kupfer (2002) com alterações realizadas pela autora. A situação apresentada a seguir caracteriza perfeitamente o mercado aéreo paulista e a atuação das empresas nesses territórios.
} 
Empresas entrantes: também chamadas de empresas potenciais, correspondem a qualquer capital interessado em atuar no mercado analisado. A etapa subsequente se dá quando estas, ainda que não capitalizadas potencialmente, oferecem uma perspectiva de cooperação com as grandes empresas, o que acarreta na lucratividade para ambos os lados.

O organograma a seguir demonstra, tautologicamente, as estruturas desses dois tipos de empresas, que definem as companhias aéreas atuantes no Estado de São Paulo. A partir das Figuras 3 e 4, é possível observar como se dão seus interesses e suas ações preeminentes no mercado, consubstanciando as necessidades das companhias mediante.

Figura 3 - Estrutura de mercado das Empresas Estabelecidas (TAM-Gol)

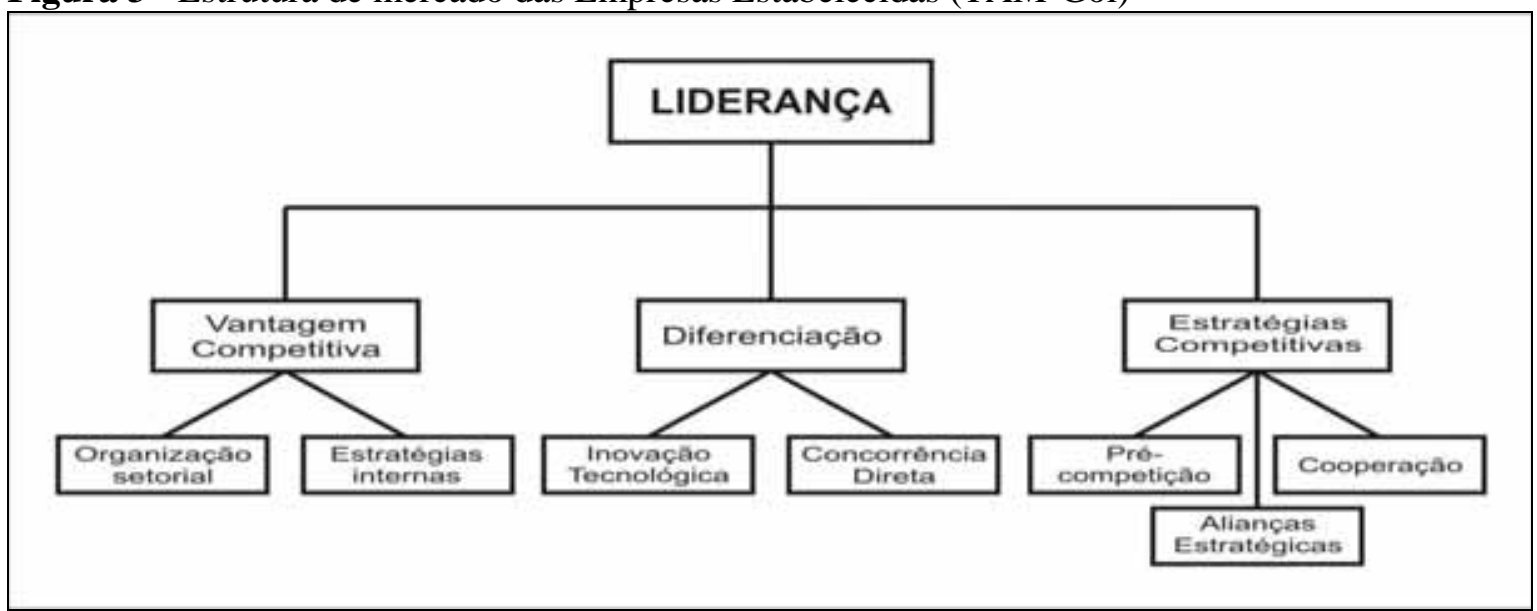

Fonte: Trabalho de campo, 2009

Org.: Camilo Pereira, 2009

Figura 4 - Estrutura de mercado das Empresas Entrantes (Passaredo-Pantanal)

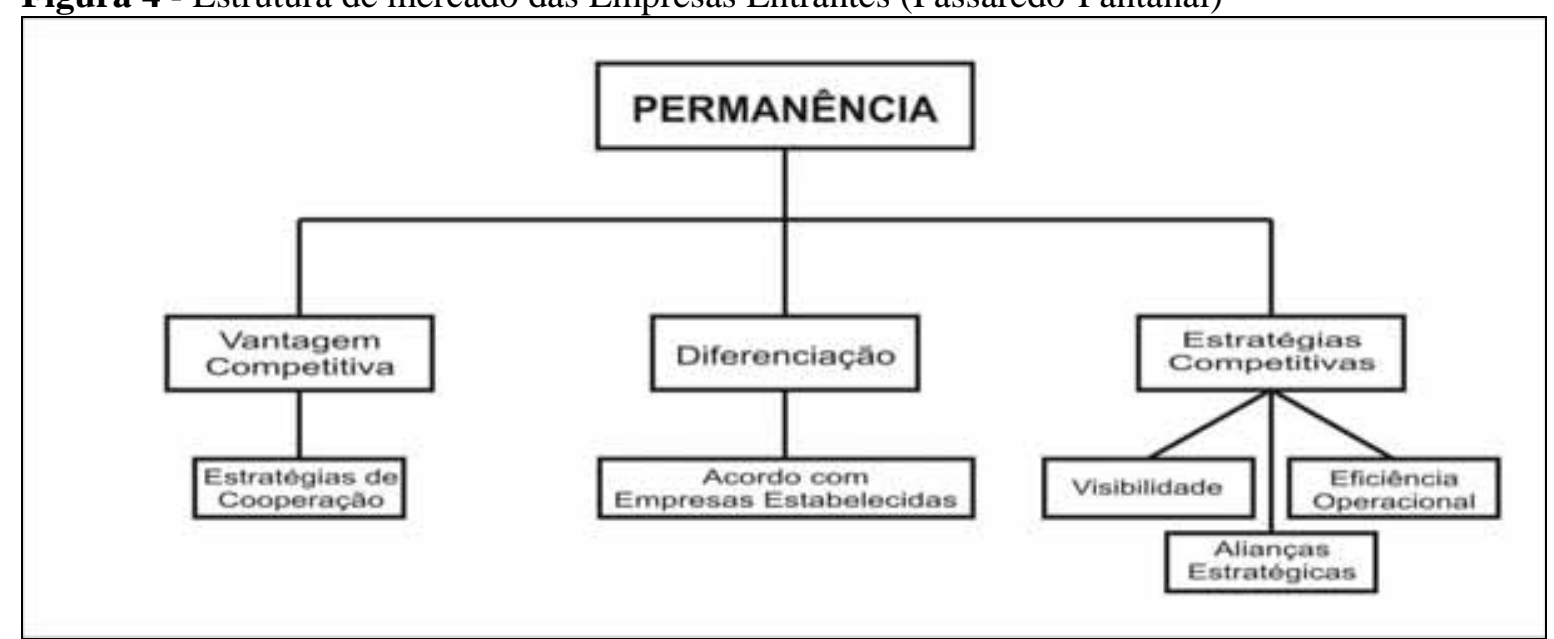

Fonte: Trabalho de campo, 2009

Org.: Camilo Pereira, 2009

A estrutura de mercado das empresas estabelecidas e das empresas entrantes conota uma ocorrência diversificada. As empresas estabelecidas atuam mediante a liderança no mercado, estabelecendo suas estratégias competitivas como forma de criar 
uma pré-competição com as entrantes. E, quando se faz necessário, coordenam alianças, estratégias de cooperação e reciprocidade que controlam a imagem destas no mercado. A diferenciação destas empresas se dá de acordo com a capacidade que possuem para inovar tecnologicamente, produzindo uma competição direta, o que também funciona como uma vantagem competitiva no mercado. As vantagens competitivas provêm de um esquema de organização e estratégias internas das próprias empresas, fortalecendo-as no mercado competitivo.

Já empresas entrantes atuam na "contra-mão" dessa situação. As entrantes organizam-se no sentido de manter suas permanências no mercado. Suas estratégias competitivas se dão como forma de dinamizar sua eficiência operacional, projetar sua marca, sua imagem no mercado. Nesse caso, as alianças estratégicas com as empresas estabelecidas cooperam para a visibilidade da empresa, o que também proporciona a diferenciação entre elas ${ }^{98}$, além de funcionar como uma vantagem competitiva.

Nesse sentido, consideramos que a estrutura de mercado das empresas estabelecidas, assim como das entrantes, expõe a dinâmica operacional dessas empresas e demonstra o caminho percorrido pelas mesmas na tentativa de coordenar suas ações no mercado e intensificar seu market share. No entanto, na medida em que as ações dessas empresas são realizadas, mediante suas estratégias de cooperação, de diferenciação, suas vantagens competitivas etc., o processo de concentração intensifica-se simultaneamente ao desenvolvimento do setor.

Em outras palavras, as empresas TAM e Gol competem para uma liderança de mercado que necessita, por vezes, da cooperação das pequenas e médias empresas, como a Passaredo e a Pantanal, uma vez que estas, embora não estejam potencialmente capitalizadas para competir no mercado aéreo, podem prejudicar suas operações se operarem sozinhas. Tal fato estimula os acordos e contratos entre elas, desfocando a essencialidade da concorrência e favorecendo, com isso, o processo de duopolização.

Ao agruparmos essas duas categorias de empresa na análise abordada neste trabalho, isto é, nas cidades paulistas, temos as definições que correspondem ao que consideramos concorrência potencial. A TAM e a Gol são grandes empresas já consolidadas, que juntas coordenam as ações do mercado, manipulando entradas, saídas, fusões, aquisições e falências.

\footnotetext{
${ }^{98}$ Quando uma empresa de pequeno ou médio porte obtém acordos comerciais com grandes companhias do mercado, ela progressivamente apresenta um maior market share frente às empresas entrantes concorrentes. Tal fato pode não ser percebido diretamente pelo usuário, mas no mercado ela demonstra uma vantagem competitiva se comparada às empresas de seu nível hierárquico.
} 
$\mathrm{Na}$ medida em que empresas entrantes manifestam-se potenciais no mercado, surgem contratos, acordos, projetos de cooperação, primeiro como uma maneira de controlar as empresas entrantes que, geralmente, não estão capitalizadas para concorrer com a TAM e a Gol e, segundo, como uma forma de barreira à entrada de novas empresas $^{99}$. Atentamos que esses acordos têm um caráter pré-competitivo, ainda que cooperem para salvaguarda das empresas entrantes. A competição entre as empresas é evidentemente real, mas possui várias facetas, que são destituídas conforme o momento em que a empresa opera em determinado local e, também, mediante as condições que o mercado oferece em dadas situações.

Apontamos inicialmente para o caráter concentrador do setor, que se constitui pela ação e coordenação das grandes companhias. Contudo, num mercado competitivo, o conceito-chave muitas vezes deixa de ser a concorrência e passa a ser a cooperação. As estratégias determinam a movimentação no mercado, a entrada e saída de empresas, assim como, também, revelam a potencialidade do setor na intervenção das regras e das normas estabelecidas no mercado. Contudo, quando a competitividade deixa de ser um fator de lucratividade, as companhias enveredam-se para as estratégias de cooperação, mesmo aquelas já estabelecidas.

Parafraseando, alegamos que cada empresa utiliza-se das opções e alternativas que possuem para controlar o mercado. Embora as grandes empresas (estabelecidas) do transporte aéreo tenham acordos comerciais entre si, que impedem a competitividade direta entre as linhas de que dispõem, essas empresas, movimentam, também, estratégias e vantagens competitivas, o que faz com que o usuário acredite na acirrada concorrência entre estas. Explicamos o que ocorre abordando a real situação dessas empresas no interior do Estado de São Paulo.

A Gol operava no mercado de Ribeirão Preto com voos para o Aeroporto Congonhas, em São Paulo. A presença da empresa junto à TAM e à Passaredo no Aeroporto de Ribeirão Preto desequilibrava o potencial das três empresas, uma vez que a demanda relativa dividia-se de acordo com os horários dos voos, com as tarifas disponíveis etc. Um acordo entre as empresas direcionou a problemática dessa competição, fazendo com que a Gol encerasse suas atividades em Ribeirão Preto, deslocando suas atividades para o Aeroporto de Presidente Prudente, onde a empresa Pantanal operava sozinha. Tal

\footnotetext{
${ }^{99}$ Adiantamos que esse não é o caso da empresa AZUL Linhas Aéreas Brasileiras, que embora seja uma empresa entrante, já é potencialmente capitalizada para concorrer com as major players como a TAM e a Gol. A essa competição chamamos de "concorrência real", quando a concorrência se dá em função do tamanho relativo da empresa e do capital que a empresa entrante dispõe para concorrer (KUPFER, 2002).
} 
acordo possibilitou à TAM a iniciativa de um contrato comercial com a Passaredo, que passou a operar conjuntamente com a TAM. Com isso, a Gol passou a operar num mercado pouco explorado e com potencial de geração de tráfego, impondo uma concorrência acirrada à empresa Pantanal, que já apresentava problemas relativos à atuação no mercado.

Esse tipo de concorrência, embora não seja amplamente considerado, consiste na prática de dumping entre as empresas, fato que é reconhecidamente existente no mercado de transporte aéreo. Embora a ocorrência desse tipo de prática seja indubitavelmente mascarada, presenciamos continuamente essa situação, ainda que a própria conivência com tal ocorrência seja sistematicamente involuntária e, principalmente, incontrolável pelo usuário do modal.

Nessa discussão, compreende-se que o poder de mercado das empresas está consubstanciado em suas estratégias, que definem os resultados obtidos no ramo. Dentro dessa perspectiva, Boof e Resende (2002, p. 74) argumentam que "quanto maior o valor da concentração, menor é o grau de concorrência entre as empresas, e mais concentrado (em uma ou poucas empresas) estará o poder de mercado".

O trabalho empírico nas empresas aéreas que atuam no mercado paulista tem demonstrado a proposição revelada pelos autores. Nota-se que a concorrência é superficial, uma vez que o poder de mercado é concentrado. Entretanto, essa concentração também é combinada e implica em uma competição imperfeita.

Embora cada companhia utilize uma estratégia ou várias estratégias, que combinam preço, acordos mútuos, qualidade, eficiência, frequência, entre outros, a incitação à competição direta é veiculada como o principal fator do mercado, quando, na verdade, o que ocorre são acordos de reciprocidade entre as empresas, no que é definido como rede de empresa (networks). Isso, em geral, favorece a concentração das grandes empresas, mas também a permanência das pequenas e médias. Assim, estes acordos assistem a uma ambiguidade do mercado, ora para credibilidade, personificação da marca das empresas já consolidadas, ora para a visibilidade e divulgação da imagem das empresas iniciantes.

Britto (2002) assevera que a consolidação das redes de empresas a partir de acordos e contratos tem como intuito conectar diferentes empresas para a formação de alianças estratégicas. Estas alianças definem um posicionamento estratégico das empresas, que contempla a exploração de oportunidades e a adequação às tendências definidas no 
âmbito de um novo paradigma empresarial, que correlaciona, por um lado, concorrência/interação e, por outro, competitividade/integração.

Exemplos desses acordos acontecem entre a TAM e a Passaredo. As duas companhias possuem contratos comerciais de voos que consistem em vender passagens em conjunto. O acordo confere à Passaredo voos com origem em Ribeirão Preto e com destino ao Aeroporto de Guarulhos, que é um aeroporto de conexões e escalas para voos internacionais. Já os voos da TAM, com origem em Ribeirão Preto, são destinados para o Aeroporto de Congonhas.

Com isso, a Passaredo e a TAM firmaram um contrato, para que as duas não compitam em voos com a mesma linha, isto é, origem e destinos para os mesmos aeroportos. Desta forma, o passageiro que fará conexão e/ou escala em São Paulo compra um único bilhete pela TAM e voa de Ribeirão Preto para o Aeroporto de Guarulhos com a empresa Passaredo e, posteriormente, embarca num avião TAM para o destino final. Com um único bilhete o passageiro viaja pelas duas empresas ${ }^{100}$. Assim, a TAM eliminou a concorrência com a Passaredo e aumentou a oferta de voos, já que oferece voos para o trajeto que possui a maior demanda, sem que para isso tenha de disponibilizar mais aeronaves. Já a Passaredo ampliou sua margem de lucro, transportando mais passageiros e, ainda, obteve um maior market share, pois passou a operar conjuntamente com a maior empresa do mercado brasileiro. Assinalamos que estes acordos influem como forma de consolidar estratégias espaciais de penetração, isto é, a interferência espacial realizada pelo grande capital, no caso, uma grande companhia aérea.

Esse tipo de acordo comercial tem como substancial intenção impor o papel que as grandes empresas realizam no mercado. De fato, há uma reciprocidade nesses acordos, mas a relação de autoridade (FIANI, 2002) é sobreposta nitidamente nesses contratos, o que se pode constatar conforme alega a própria administração comercial de uma das empresas analisadas: "o papel da empresa Passaredo e de outras empresas regionais, que possuem contratos comerciais com grandes empresas, é alimentar os hubs principais da TAM, isso é visibilidade no mercado" ${ }^{\text {"101. }}$.

\footnotetext{
${ }^{100}$ Para isso, a TAM acaba oferecendo descontos ou absorve o valor de uma rota etc.

${ }^{101}$ Segundo entrevistas, esses acordos cooperam para o crescimento das pequenas e médias empresas, que estão num estágio incipiente de consolidação. Ricardo Cagno, Diretor Comercial e Planejamento da empresa Passaredo Linhas Aéreas, afirma que: "É muito vantajoso para a Passaredo, pois a empresa continua no mercado e transportando clientes da TAM, que passam a conhecer a Passaredo. Isso contribui para o próprio crescimento da nossa empresa, já que somos regional. Para a TAM é bom, pois continua operando com esses acordos e faz com que o cliente não se esqueça da empresa, mesmo numa linha de menor fluxo."
} 
O mesmo não é observado na cidade de Presidente Prudente, onde encontramos as empresas Pantanal, Gol e mais recentemente a Passaredo. Como já citado, a empresa Gol iniciou suas operações no aeroporto de Presidente Prudente com a finalidade de acirrar a concorrência com a empresa Pantanal. Desde o período de atuação das empresas no mercado da cidade, não observamos nenhum acordo de cooperação que pudesse articular as empresas, pelo contrário, a concorrência entre as duas tem sido constante, enfraquecendo a atuação da empresa Pantanal, que já se encontrava com problemas financeiros, técnicos e jurídicos no mercado aéreo.

Nota-se, também, que a entrada da Gol no mercado prudentino, teve como estratégia enfraquecer e agravar a atual situação da empresa concorrente. Outra observação registrada nesse estudo é que a Pantanal tem um grande número de slots concedidos no Aeroporto de Congonhas, principal conexão da aviação regional paulista e, sobretudo, da empresa Gol. Simultaneamente, o agravamento da situação da empresa Pantanal e a paralisação de suas operações implicariam e ainda pode implicar na redistribuição de seus slots no Aeroporto de Congonhas, favorecendo com isso a empresa Gol. Constata-se que, ainda que essa estratégia não seja difundida, o resultado das ações da empresa Gol tem demonstrado seus interesses empresariais, uma vez que a mesma tem sistematicamente investido em frequência de voos, destinos, horários, oferta de assentos, conexões etc., com origem na cidade de Presidente Prudente.

Novos cenários serão desenhados com a entrada da empresa Passaredo no mercado de Presidente Prudente. Ainda nesse contexto, a especulação da empresa AZUL no mercado prudentino gerará mais disputa, acordos e, consequentemente, oferta de voos, maior número de empresas, preço e oferta de transporte aéreo nesse mercado, favorecendo, com isso, a cidade de Presidente Prudente, sua região de influência, que passa também a dispor de mais opções desse serviço.

No que se refere aos acordos, destacamos que os mesmos descaracterizam a concorrência territorial entre as empresas e fomenta, ainda mais, a ausência de rivalidade, o que, de forma geral, implica em desvantagem para o usuário, que dispõe de uma menor opção de empresas e, principalmente, de preço. A presença de um Estado forte e controlador que preze a concorrência potencial para o transporte aéreo é essencial para o crescimento do setor, no entanto o que se observa é a fragmentação partidária dentro dos órgãos de administração, o que prejudica e, por vezes, impede o desenvolvimento do transporte aéreo regional. 
Já para a perspectiva empresarial, as vantagens desse tipo de acordo comercial é preconizado por ambas as empresas. Para a TAM, esse acordo é compensatório, pois a companhia não pode optar pela não inclusão de aeronaves custosas em trajetos regionais, que geralmente possuem baixa densidade de tráfego. No entanto, não deixa de atuar no mercado regional, uma vez que o usuário adquire o bilhete na empresa TAM.

Ao discorrer sobre essas ações, enfatizamos a sistemática que perfaz as opções das empresas em relação aos acordos comerciais firmados entre as mesmas. O resultado dessa organização estratégica que, geralmente, é coordenada pelas grandes empresas, induz ao que chamamos de formação de clusters $^{102}$ voluntários. Ao analisar essa situação no mercado aéreo paulista, nota-se que, rotineiramente, essas ações ampliam-se demasiadamente, implicando na ausência da concorrência.

Por fim, constatamos que o duopólio existente no mercado aéreo paulista estimula, por um lado, a concentração ruinosa, pois intensifica a liderança das major players, constituindo ainda mais o market share destas, além de ampliar o poder dessas empresas em relação à barreira à entrada. Por outro lado, favorece a cooperação de estratégias coordenadas, uma vez que as pequenas e médias empresas aéreas aceitam as estratégias e os acordos de cooperação como forma de garantir sua permanência no mercado e, as grandes, como maneira de controlar a expansão de suas concorrentes entrantes.

Se tais funções são legais, concluímos que as cidades (o mercado) são, por fim, as receptoras das ações e reações das empresas e do movimento resultante no mercado aéreo. Todavia, é importante destacar que cada vez menos o usuário tem a opção de voar pela empresa que escolhe, uma vez que todas cooperam para a manutenção de uma competitividade inexistente, embora pronunciada por elas mesmas.

\subsection{Considerações finais ao capítulo IV}

Tratamos nesse capítulo da concorrência no setor de transporte aéreo, tendo como fundamentais contextos as estratégias e as vantagens competitivas que as empresas utilizam para permanecerem e controlarem o mercado.

\footnotetext{
102 Clusters: "Termo em inglês que significa 'blocos' ou 'agrupamentos' e utilizado em vários contextos para designar o agrupamento de elementos comuns para um determinado fim (SANDRONI, 2005, p. 151).” Chamamos de clusters voluntários, uma vez que a formação de blocos com o intuito de planejar e coordenar estratégias de mercado são realizados voluntariamente entre as grandes empresas que manipulam o setor em favor de uma maior consolidação e visibilidade no mercado e entre as pequenas e médias empresas, que se comprometem nesses acordos comerciais com o fim único de permanecerem no mercado.
} 
Para tal elucidação, partimos do exame de autores que tratam da questão em circunstâncias divergentes, porém complementares e que contribuíram para a análise da atual situação da aviação comercial no Brasil e no Estado de São Paulo.

Assim, Porter (1986, 1989, 1996, 1999) forneceu uma avaliação densa sobre a competição, enfocando a empresa como o "fio condutor" de todo o processo de inovação, de criação e sustentação de estratégias e vantagens competitivas, de configuração da cadeia de valor e da diferenciação do produto, entre outros aspectos. Estes elementos proporcionaram a elaboração de um contexto próprio da análise sobre a empresa, mas também permitiram compreender que a empresa é apenas mais um componente do setor, que possui fatores que perpassam uma análise específica da empresa por si só.

O transporte aéreo está inserido num conjunto de condições que identificam a empresa como um elo de conexão que projeta e fomenta transformações inerentes ao desenvolvimento do setor. Porém, o setor está imbricado no sistema geral da economia brasileira e os ajustes e desajustes políticos e econômicos que ocorrem mundialmente e nacionalmente o afetam independentemente da articulação empresarial.

Tomados dessa informação, salientamos que, embora o desencadeamento das mudanças estratégicas e conturbadas que o setor de transporte aéreo insere-se, importantes projeções são realizadas pelas empresas aéreas, que têm um poder de atuação extremamente influenciador e que geram revezes e situações elementares para o setor como um todo.

Enfatizamos que é no Estado de São Paulo que essas influências verificam-se mais contundentes, primeiro porque é o Estado que possui o segmento regional mais desenvolvido em razão de sua densidade técnica e, segundo, em razão da complexidade do processo de desconcentração urbano-industrial que favorece o transporte aéreo regional e as interfaces do interior com a capital.

Nota-se que é a partir das estratégias e vantagens competitivas das empresas que o setor de transporte aéreo desenvolve-se, seja num sistema de competição direta, o que pouco se verifica no setor, seja na cooperação entre as empresas, situação usualmente encontrada no setor.

Constatamos que a capacidade das empresas inovarem-se tecnologicamente está relacionada ao seu processo de capitalização. As grandes empresas como a TAM e a Gol possuem um potencial de competitividade consolidado, o que intimida as pequenas e médias empresas que, geralmente, entram no setor com um market share restringido, fomentando, com isso, os processos de fusões, acordos de cooperação etc. 
Essas práticas impõem um conjunto de fatores que implicam em consequências para o usuário, que cada vez menos dispõe de variedade, no que diz respeito ao preço e ao número de empresas que oferecem o serviço aéreo. Isso é perceptível quando se analisa as empresas que encerraram suas operações, que faliram, fundiram ou foram adquiridas pelas grandes empresas do setor nos últimos anos.

A concorrência e o poder de atuação das empresas no mercado estão referendados a partir daquilo que o usuário elege como bom ou ruim. As práticas competitivas fazem-se mediante as opções do usuário do modal aéreo, que determina a liderança e a permanência das empresas no mercado.

Neste capítulo, procuramos chamar a atenção para o uso da tecnologia tanto pelas empresas aéreas quanto pelos usuários do modal aéreo. Esse uso se dá a partir da capacidade de inovação das companhias que, cotidianamente, lançam mão de novos e mais eficazes sistemas de informatização que facilitam e intensificam a comodidade e a rapidez do processo de compra, pagamentos de passagens, embarque e desembarque, despache de malas, check in etc.

Nessa lógica, ressaltamos que a atuação da empresas nas cidades pesquisadas, bem como suas estratégias mercadológicas tem refletido na produção do espaço urbano, na redefinição territorial paulista, tornando as cidades de Araçatuba, Bauru, Marília, Presidente Prudente, Ribeirão Preto e São José do Rio Preto centros urbanos territorialmente competitivos.

Com base nessas análises, observamos ainda que as ações das empresas aéreas no interior paulista contribuem para a atração de mais investimentos para os aeroportos, ainda que estes recursos não sejam suficientes. Promove ainda a atração de empresas de outros setores, fomentando com isso investimentos em demais áreas como indústrias, comércios e serviços.

Observa-se também que estas cidades participam ativamente da rede urbana paulista, uma vez que o transporte aéreo é um modal que as inserem no circuito espacial da circulação. As repercussões do setor aéreo nas cidades analisadas podem ser melhor compreendidas quando se considera a articulação/integração territorial que estas cidades vêm atingindo mediante o processamento do transporte aéreo. Um exemplo dessa articulação extra-regional é vista pela empresa Passaredo, que tem expandido suas ligações aéreas com os Estados de Minas Gerais, Goiás, Mato Grosso, Paraná, Rio de Janeiro etc., tais fatores promovem a intensificação das interações espaciais, a integração territorial e, sobretudo, o desenvolvimento econômico regional. 
Dentre mais, atentamos ainda para o caráter competitivo e cooperativo das empresas, que reconhecidamente agem mediante interesses particulares e estratégias de mercado coniventes, que têm a finalidade de compor e reger o mercado de transporte aéreo no Brasil. Ressaltamos, nesse ínterim, que o duopólio existente faz parte e, também, caracteriza o papel desses acordos comerciais entre as grandes, médias e pequenas empresas, que de acordo com suas influências e permissividades, estruturam um setor desregulamentado por opção e cooperação do Governo. 
CONSIDERAÇÕES FINAIS 
Propomos, neste trabalho, compreender, numa perspectiva da Geografia dos Transportes, Circulação e Logística o desenvolvimento do setor de transporte aéreo regional no Estado de São Paulo. Nossa escolha em investigar os fluxos de passageiros partiu de uma seleção de fatores, que dentre as análises já apresentadas, parecia-nos a mais interessante do ponto de vista geográfico, já que há poucos trabalhos no âmbito da Geografia que trate o tema "transporte aéreo".

Nesse sentido, trazemos à tona a discussão sobre o transporte aéreo, considerando alguns fatores essenciais para essa abordagem, quais sejam: as interações espaciais, as redes geográficas, o desenvolvimento regional e a integração territorial, a partir de uma análise geoeconômica. Ora alguns desses elementos avivaram-se mais, ora menos, mas, de toda forma, procurou-se ajustá-los como maneira de expandir e, simultaneamente, refinar o que se procurou examinar. Estes elementos contribuíram para nossa leitura, uma vez que se caracterizaram como complementos da pesquisa. Além disso, favoreceram a construção do referencial teórico.

Buscando uma assimetria entre os capítulos, de forma que os assuntos elencados se ordenassem para uma melhor compreensão, tratamos primeiramente do transporte aéreo em seu caráter histórico-desenvolvimentista, ou seja, analisamos como se deu o crescimento do setor, ressaltando uma ordem cronológica que focalizou as políticas para a promoção do transporte aéreo nacional e mais precisamente do segmento regional. Mediante esta análise notamos que o setor carece de políticas que orientem seu desenvolvimento, já que as últimas políticas estritamente direcionadas para o segmento regional datam da década de 1970, após esta década o que se observa é um desencontro entre o papel exercido pelo poder público e a atuação das empresas.

Esta descontinuidade provoca uma inadequação incessante no setor de transporte aéreo, seja em relação a atuação empresarial, seja em relação ao contínuo processo de desregulamentação em que passa o setor de transporte aéreo brasileiro.

Os contornos que fizeram do transporte aéreo um setor desregulamentado invadiu um campo de compreensão maior do que o aqui analisado. Ou seja, a desregulamentação setorial ocorrida após a década de 1990 insere-se num amplo e conturbado cenário político e econômico do Brasil, no qual não apenas o setor aéreo foi lesado, mas setores estratégicos da economia brasileira viram e ainda se vêem no colapso da ausência de um marco regulatório, que defina e regulamente as ações dos setores e das empresas de cada ramo. 
O ano de 1989 iniciou um processo de transformação que, com o passar do tempo, aprofundou e, de certa forma, afundou a política e a economia brasileira no que hoje se denomina neoliberalismo. Estas transformações foram constituídas a partir de um contexto político-econômico que reestruturou o setor no Brasil. Entre as modificações que foram admitidas ao setor de transporte aéreo brasileiro destaca-se a "Política de Flexibilização do Transporte Aéreo”, que ocorreu pari passu com as opções políticas do Brasil, fator, este, que orientou um setor em crise, ou melhor, um setor sujeito às contradições do passado, que cumularam para uma crise cíclica que, constantemente, reflete em mazelas para o crescimento do transporte aéreo brasileiro.

O setor de transporte aéreo conviveu com um ambiente de grandes transformações a partir da década de 1990, período que ficou marcado pelo processo de desregulamentação do setor supracitado, tendo sido orientado por uma política neoliberal adotada pelos Governos brasileiros, como o de Fernando Collor de Melo, Itamar Franco e o de Fernando Henrique Cardoso.

Nesse mesmo contexto de análise, ao refletirmos sobre a circulação aérea, observamos que o setor de transporte aéreo no Brasil tem apresentado grandes revezes, orientados pela admissão de medidas internacionais, sobretudo aquelas difundidas em países ditos desenvolvidos, tais como os Estados Unidos. Estas transformações ora contribuíram para a dinâmica territorial do setor, ora implicaram em apostasias para a otimização do modal aéreo, na medida em que revelam opções negligentes com o crescimento do setor aéreo, devido à importação de ideias e parâmetros de desenvolvimento que, por vezes, não se enquadram à complexidade do Brasil.

Assim, os desdobramentos desse processo acarretaram consequências diversas para o setor e refletiram um contexto político-econômico nem sempre positivo para o segmento regional, minimizando sua importância e alterando funções estratégicas de interconexão e desenvolvimento das cidades paulistas que eram servidas pelo transporte aéreo.

A confirmação da Política de Flexibilização do Transporte Aéreo indexou no setor aéreo brasileiro um programa de medidas que alteraram as estratégias até então definidas pelo transporte de tal caráter no país, ou seja, a função de integração territorial. Em outras palavras, a desregulamentação inseriu o setor num processo de liberalização do mercado aéreo, que favoreceu, por um lado, as grandes empresas, que dispuseram de um mercado livre, desregulamentado e totalmente flexível às formas de concorrência e, por outro, o usuário do modal, que passou a obter um maior número de empresas aéreas 
operando as mesmas rotas, de mais cidades servidas, bem como a facilitação do crédito e, em alguns casos, a redução do preço das passagens aéreas.

É nesse sentido, que ao tratarmos o segundo capítulo dessa Dissertação em consonância com as atribuições feitas ao primeiro capítulo, nos centramos no papel desempenhado pelos diversos órgãos de administração do setor, isto é, no âmbito federal e estadual.

Nitidamente observa-se uma quase ausência de investimentos nos complexos aeroportuários do Estado de São Paulo. A inadequação dos aeroportos é resultado também da falta de planejamento, ou melhor, da incoerência de um planejamento que se baseia em planos como o PAESP, que podem até funcionar na teoria, mas na prática não imprimem resultado algum, ora por falta de conhecimento do PAESP pelos administradores dos aeroportos pesquisados, ora pela ineficácia de um projeto que trabalha com perspectivas, não se atendo as especificidades da realidade vigente de cada aeroporto.

A questão relacionada à promoção de políticas públicas para a viabilização do setor aéreo tem, atualmente, uma maior atenção do Governo brasileiro, no entanto, ainda insuficiente no que tange ao segmento regional. A necessidade de planejamento que ordene a disponibilização da oferta com capacidade de geração de demanda é essencial para promover o desenvolvimento aeroviário, ampliando conexões e escalas em cidades que possuem demanda, como no caso das cidades destacadas nessa pesquisa, e com isso interligar cidades que não tem acesso ao modal. São políticas públicas dessa ordem que promovem a integração territorial tão requerida pelo país.

Ainda no exame sobre a desregulamentação, destacamos que a desmistificação do Estado como poder regulatório tem demonstrado que o processo de desregulamentação do setor de transporte aéreo, em especial no Estado de São Paulo, é causa e efeito da importação de modelos de outros países, que não reproduzem as mesmas consequências para o Brasil. Se por um lado a adoção do processo de desregulamentação dos Estados Unidos no Brasil repercutiu em vantagens para o setor aéreo em âmbito nacional e internacional, por outro, prejudicou o desenvolvimento do segmento regional, que é mais sensível às transformações conjunturais que são processadas no setor, por comporem um ramo de intensas oscilações econômicas.

Ainda que o processo de desregulamentação tenha favorecido as empresas aéreas regionais entrantes, o Estado não ofereceu suporte para que o transporte aéreo regional tivesse e tenha maior representatividade frente ao mercado, ora em razão da 
ausência de planejamento, ordenamento territorial, planificação, projetamento, ora devido ao descaso do Poder Público com o segmento regional.

A maior flexibilidade da ação regulamentadora trouxe ganhos inquestionáveis para o setor de transporte aéreo e propiciou a utilização do modal por uma importante demanda da sociedade, que, até então, estava reprimida, devido aos valores cobrados pelo serviço aéreo. Enfatizamos, ainda, que esse processo favoreceu, num primeiro momento, a maior competitividade entre as empresas, o que resultou, inicialmente em vantagens para o usuário. Abriram-se novos nichos de mercado e intensificou-se a escala de demanda pelo modal e isso repercutiu positivamente, tanto para as empresas que foram forçadas a modernizar-se como para os consumidores, que dispuseram de maiores e melhores ofertas de transporte aéreo e, consequentemente, da viabilização tarifária, das formas de compra e emissão de bilhetes, parcelamento de passagens, compra pela internet e disponibilização de todo aparato tecnológico das empresas. Fatores, estes, que se constituem nas estratégias e nas vantagens competitivas das companhias.

Compreendemos que as prioridades do país não se circunscrevem em manter e equipar um serviço tal como o transporte aéreo. No entanto, salientamos que se o planejamento não conceber as condições básicas para o desenvolvimento do setor, corremos o risco de restringir o potencial produtivo de regiões dinâmicas e manter os obstáculos à maior integração do território nacional, por precariedade ou falta de atendimento de serviços de transporte aéreo.

O país, ao adotar tal política neoliberal, formulou um conjunto de medidas que pouco contribuiu para a economia brasileira. $\mathrm{O}$ neoliberalismo reproduzia/reproduz na periferia do sistema capitalista, a proposta do "Estado mínimo", isto é, à crítica ao Estado regulador e protecionista. Com isso, a redução da ação estatal, conjuntamente à desregulamentação da economia, à abertura econômica do país e, consequentemente, às liberalizações do comércio e dos fluxos internacionais de capitais, retardou o desenvolvimento industrial e provocou o desencadeamento de iniciativas políticas que, equivocadamente, privatizaram setores estratégicos da economia nacional.

O setor de transporte aéreo brasileiro foi um dentre os tantos setores econômicos que sentiram as consequências do processo de desregulamentação. Somam-se a isso os desajustes econômicos contextualizados pelas crises cíclicas da economia que intensificaram a defasagem do crescimento do setor, sobretudo em âmbito regional.

Nessa abordagem iniciamos o terceiro capítulo tratando especificamente dos fluxos aéreos no Estado de São Paulo. Para isso, partimos de um conjunto de dados 
organizados por órgãos de pesquisa como IBGE, IPEA, REGIC, SEADE etc., como forma de apresentar as características de cada centro urbano pesquisado. Sendo assim, destacamos as ligações (origem/destino), frequência, escalas, no intuito de demonstrar a dinâmica do transporte aéreo regional paulista.

Nesse contexto de análise, notamos claramente a hierarquização da estruturas de cidades no Estado de São Paulo. A partir dessa observação atestamos que o transporte aéreo é mais um setor da economia que ora é resultante, ora é resultado dessa hierarquização das cidades. Ainda que alguns autores considerem que a consolidação das redes geográficas tenha favorecido uma maior articulação entre as cidades que por sua vez inibe a hierarquia das cidades no Brasil e, sobretudo, no Estado de São Paulo, o que observarmos é que as cidades são proporcionalmente mais ativas, mais dinâmicas seguindo uma estruturação que considera a densidade demográfica, o PIB, a diversificação das indústrias, o processo de urbanização, o nível de centralidade exercido etc.

Essa relação hierárquica é destacada e comprovada quando apresentamos o número de passageiros que utilizam o modal aéreo em seus deslocamentos por par de cidades, o número de empresas aéreas por cidades, assim como a frequência de voos das mesmas. Torna-se claro que a liderança dessa situação tem como principal cidade Ribeirão Preto que hierarquicamente consolida-se como o principal hub regional ou secundário do interior paulista, a mesma possui a maior densidade demográfica, o maior PIB, diversificação industrial, um acentuado processo de urbanização e exerce um alto nível de centralidade.

O Estado de São Paulo, caracterizado por sua complexa configuração territorial, permanentemente utilizada nas principais interconexões aéreas, fez com que o modal aéreo se tornasse um dos meios de transporte mais utilizados nas ligações entre o interior-capital e capital-interior. E, a partir desse processo de desregulamentação e de seus resultados, o setor aéreo regional paulista tem sido constantemente atingido, devido à reestruturação política e administrativa que, com suas transformações, prejudicou, por um lado, as empresas áreas remanescentes e as entrantes, e por outro lado, o usuário do modal.

Apesar da atual crise, denominada "apagão aéreo", ter se revertido em perdas substanciais para o segmento regional, nota-se que a procura pelo transporte aéreo tem aumentado ano a ano nas cidades do interior paulista. Tal fato aponta para a necessidade de planejamento, investimentos e programações estratégicas do Poder Público, como forma de arregimentar o setor, que ainda é subutilizado no Estado. No entanto, é nítido o que muitos autores que trabalham a temática denominam como: falta vontade, dedicação e 
conhecimentos específicos para as que autoridades notem a importância do transporte aéreo regional no Brasil.

Constatamos que a escala de operações aéreas no Estado tem revelado que o segmento regional oferece grandes possibilidades de desenvolvimento econômico regional, para a constituição de $h u b s$ regionais ou hubs secundários para o transporte aéreo paulista, bem como se caracteriza pela integração territorial e pela dinâmica das interações espaciais, em razão, sobretudo, da estrutura de cidades justaposta em redes que favorecem as interconexões aéreas.

Os níveis escalares do transporte aéreo têm atingido territórios de outros Estados, fato, este, que tem contribuído para o desenvolvimento do modal aéreo na escala regional. No entanto, são necessários mais investimentos em infraestrutura operacional, bem como políticas de incentivo, planejamento, intervenção normativa e regulamentadora para o transporte aéreo. Tais políticas somente serão possíveis com a maior atuação estatal, como forma de arregimentar a estrutura operacional aérea e, também, a dinâmica empresarial do setor.

Assim, após a análise da evolução e do desenvolvimento do setor aéreo, da gestão do transporte aéreo, dos fluxos de passageiros no Estado de São Paulo e da dinâmica espacial de origem e destino da fluidez territorial, iniciamos o quarto capítulo, que remete uma discussão sobre as estratégias das empresas aéreas e a repercussão de suas ações no território paulista.

O encerramento do trabalho nos revelou um cenário divergente do esperado. As análises partiam da compreensão de que se tratava de um setor altamente competitivo, todavia, as pesquisas e os trabalhos de campo revelaram uma situação oposta. A eliminação das concorrentes não é o principal objetivo das companhias aéreas, até porque a concorrência permite a comparação e isso faz com que a empresa mantenha sua vantagem competitiva no mercado. As grandes empresas não sentem a necessidade de romper a estrutura empresarial do transporte aéreo brasileiro, visto que as pequenas e médias cumprem um papel totalmente estratégico para o setor, alimentando as grandes e favorecendo a estabilidade e a permanência de ambas. Com isso, nota-se a complexa situação de "cooperativa", embora este termo não prospere para uma ação que favoreça o bem estar do usuário, uma vez que impede a concorrência e inabilita a diversidade de opções de empresas.

Embora as grandes empresas sobreponham-se às pequenas e médias, a situação existente é de um sistema de cooperação, no qual as grandes empresas coordenam todo o 
processo de acordos e contratos, permitindo seu estabelecimento e a permanência das pequenas e médias. A estratégia espacial das empresas repercute na ação das companhias, assim como o potencial de intervenção no mercado. A partir de suas atuações, acordos e contratos que modelam espacialmente o setor de transporte aéreo, percebemos a consolidação de um processo permissivo de cooperação, no qual o grande capital organiza o mercado.

Compreendemos, ainda, que o problema não consiste na demanda pelo modal aéreo e muito menos na oferta, mas sim na falta de ação regulamentadora que coordene o mercado, em favor do bem estar do usuário e do desenvolvimento econômico regional do interior paulista.

Nessas condições, percebe-se que quando foi exigida uma maior espacialização dos processos econômicos e de concorrência no Estado de São Paulo, as cidades destacadas nesta pesquisa constituíram-se como uma alternativa de desconcentração urbano-industrial, ora por representarem elos entre os setores de produção e consumo, ora por constituírem eixos de desenvolvimento no Estado.

Nessa lógica, tal processo contribuiu para o dinamismo econômico que no decorrer do tempo estes centros urbanos foram adquirindo. Foi no intuito de considerar este processo a partir do transporte aéreo que chegamos às considerações finais, as quais nos revelaram que as repercussões territoriais, da produção, da reprodução, da estruturação e da reestruturação do espaço conduzem a um processo de desenvolvimento econômico regional, em que as interações espaciais, as redes, a integração territorial e a circulação são elementos que, inegavelmente, produzem e reproduzem os espaços onde vivemos.

Em síntese, tendo como perspectiva a crise que o setor aéreo está inserido, discorremos, aqui, sobre o transporte aéreo regional no Estado de São Paulo, compreendendo sua estrutura organizacional. Consideramos que este segmento é de suma importância para o desenvolvimento econômico regional, além de se configurar enquanto um vetor de circulação e mobilidade territorial que confere na dinamicidade empreendida pelo modal aéreo e na articulação entre os territórios a partir das redes geográficas, como indutores do processamento das interações espaciais e da integração territorial.

Assim, procuramos desvendar, ainda que preliminarmente, a "caixa-preta" do transporte aéreo regional paulista. 
REFERÊNCIAS BIBLIOGRÁFICAS 
ALMEIDA, Luis Cantanhede Filho. A evolução do transporte aéreo no Brasil. In: DEFFONTAINES, P. Geografia Humana do Brasil. Rio de Janeiro: Casa do Estudante do Brasil, 1952, p. 236-268.

ALMEIDA, Paulo Henrique. Aeroportos e desenvolvimento local - o caso de Salvador. In: ALMEIDA, P. H. de; BRITTO, E. A. de; MENDONÇA, J. (Org.). Serviços estratégicos na Região Metropolitana de Salvador. Salvador: SEI, 2004, p. 107-136.

ALMEIDA, Edmar L. F. de. LOSEKANN, Luciano. Estratégias de Propaganda e marketing. In: KUPFER, D; HASENCLEVER, L. (Orgs.). Economia Industrial: fundamentos teóricos e práticas no Brasil. São Paulo: Campos, 2002.

ANDERSON, Dolle Abel. A aviação comercial brasileira. João Pessoa/PB: Editora Universitária/UFPB, 1979.

ARROYO, María Mónica. Dinâmica territorial, circulação e cidades médias. In: SPOSITO, E. S.; SPOSITO, M. E. B. (Orgs). Cidades Médias: produção do espaço urbano regional. São Paulo: Expressão Popular, 2006, p. 71-85.

AVELLAR, José Virgílio Guedes et al. A eficiência operacional do transporte aéreo brasileiro. In: Brasil Engenharia Transporte. São Paulo, 2007, p. 122-130.

BARAT, Josef. O plano de voo da aviação regional. In: Revista Custo Brasil. Rio de Janeiro, Ano 3, n. 17, 2008.

BARROSO CARAVACA, Inmaculada. Los nuevos espacios ganadores y emergentes. EURE (Santiago), vol.24, n.73, 1998, p.1-3.

BEGUIN, Hubert. La géographie économique. In: Les concepts de la géographie humaine. BAILLY, Antoine (Coord.). $3^{\text {a }}$ Ed. Paris: Masson, 1995, p. 129-138.

BELTRÃO SPOSITO, Maria Encarnação. As cidades médias e os contextos econômicos contemporâneos. In: BELTRÃO SPOSITO, M. E. (Org). Urbanização e cidades: perspectivas geográficas. Presidente Prudente/SP: [s.n], 2001.

BELTRÃO SPOSITO, Maria Encarnação et al. O estudo das cidades médias brasileiras: uma proposta metodológica. In: BELTRÃO SPOSITO, M. E. (Org). Cidades Médias: espaços em transição. Presidente Prudente/SP: Expressão Popular, 2007, p. 35-67.

BELTRÃO SPOSITO, Maria Encarnação. O chão em pedaços: urbanização, economia e cidades no Estado de São Paulo. Tese (Livre Docência em Geografia). Universidade Estadual Paulista, FCT. Presidente Prudente, 2004.

BENKO, George. Economia, Espaço e Globalização na aurora do século XXI. São Paulo: Hucitec, 1996.

BINDER, Marcelo P. Estratégias Genéricas: Posições Discretas ou Contínuas? In: Anais da Associação Nacional de Pós Graduação e Pesquisa em Administração. Rio de Janeiro, 2003. 
BOFF, Hugo; RESENDE, Marcelo. Concentração Industrial. In: KUPFER, D; HASENCLEVER, L. (Orgs.). Economia Industrial: fundamentos teóricos e práticas no Brasil. São Paulo: Campos, 2002.

BORDO, Adilson. Os eixos de desenvolvimento e a estruturação urbano-industrial do Estado de São Paulo. In: Revista Electrónica de Geografía y Ciencias Sociales. Universidad de Barcelona, 2005. Disponível em: <http://www.ub.es/geocrit/sn/sn-19479.htm>. Acessado em: 09/09/2008.

BRASIL. Agência Nacional da Aviação Civil (ANAC). Anuários Estatísticos. Rio de Janeiro, 2008.

BRASIL. Empresa Brasileira de Infraestrutura Aeroportuária (INFRAERO). Dados Econômicos. Brasília, 2008.

BRASIL. Instituto Brasileiro de Geografia e Estatística (IBGE). Dados estatísticos. Rio de Janeiro, 2008.

BRASIL. Instituto de Pesquisa e Estatística Aplicada (IPEA). Dados estatísticos. Rio de Janeiro, 2001.

BRASIL. Conselho Nacional de Transportes. Planos de Viação: evolução histórica (1808-1973). Rio de Janeiro, 1973.

BRASIL. Regiões de Influência das Cidades (REGIC). Dados estatísticos. Rio de Janeiro, 2007.

BRASIL. Fundação Sistema Estadual de Análise de Dados (SEADE). Dados estatísticos. Rio de Janeiro, 2008.

BRASIL. 150 Anos de Transportes no Brasil. Ministério dos Transportes. Rio de Janeiro: Centro de Documentação e Publicações, 1974.

BRITTO. Jorge. Diversificação, competências e coerência produtiva. In: KUPFER, D; HASENCLEVER, L. (Orgs.). Economia Industrial: fundamentos teóricos e práticas no Brasil. São Paulo: Campos, 2002, p. 307-342.

BURLE, Lauro Lobo. Transporte aéreo no Brasil: a crise da aviação comercial. In: Revista Indicadores Econômicos FEE. Secretaria da Coordenação e Planejamento. Fundação de Economia e Estatística Siegfried Emanuel Heuser. Porto Alegre/RS, v. 31, 2003, p. 5-18.

BUSTO, André de Carvalho; TUROLLA, Frederico Araújo, OLIVEIRA, Alessandro Vinícius Marques de. Modelagem dos impactos da política de flexibilização na competição das companhias aéreas brasileiras. In: Revista Economia e Sociedade. Campinas/SP, v. 15 , n. 2 (27), 2006, p. 327-345.

CAMPOLINA DINIZ, Clélio. A questão regional e as políticas governamentais no Brasil: In: Textos para discussão. CEDEPLAR: Belo Horizonte/MG, 2001.

CAMPOLINA DINIZ, Clélio. A busca de um projeto de Nação: o papel do território e das políticas regional e urbana. In: Revista Economia Selecta. Brasília, 2006. 
CAPPA, Josmar. Os aeroportos de Viracopos e de São José dos Campos e as estratégias empresariais no mercado mundial. In: Pesquisa \& Debate. São Paulo, v.18, n. 1, 2007, p. 67-82.

CASTELLS, Manuel. A sociedade em rede. São Paulo: Paz e Terra, 2001.

CASTRO, Newton de; LAMY, Philippe. Desregulamentação do setor transporte: o subsetor transporte aéreo de passageiros. In: Instituto de Pesquisa Aplicada - IPEA, (Texto para Discussão, 319), p. 1- 62, 1993.

CENTRO DE DOCUMENTAÇÃO E MEMÓRIA DA COMPANHIA GOL TRANSPORTES AÉREOS. Case Memória: uma história de sucesso. São Paulo, 2009.

CHEPTULIN, Alexander. A dialética materialista: categorias e leis da dialética. São Paulo: Alfa-Ômega, 1982.

CHESNAIS, François. A Mundialização do Capital. São Paulo: Xamã Editora, 1996.

CHOLLEY, André. Observações sobre alguns pontos de vista geográficos. In. Boletim Geográfico. Ano XXII, n. 179 e 180. Rio de Janeiro: IBGE, 1964.

COELHO, Rodrigo Pereyra de Sousa. Impactos da desregulação do setor aéreo comercial sobre os trabalhadores: uma análise dos casos brasileiro e norteamericano. Dissertação (Mestrado em Geografia). Campinas/SP: Unicamp, 2003.

CODATO. Adriano Nervo. Sistema estatal e política econômica no Brasil pós-64. São Paulo: Hucitec. Economia e Planejamento Série Teses e Pesquisas, 1997.

CORDEIRO, Helena Kohn; LADEIRA, Francisco Sérgio Bernardes. O espaço aéreo favorece a desterritorialização? In: SANTOS, M; SOUZA, M. A. A. de; SILVEIRA, M. L. Território: Globalização e Fragmentação. São Paulo: Hucitec, 1996, p. 283-295.

CORDEIRO, Helena Kohn; LACERDA, Francisco Sérgio Bernardes. Os dois circuitos do sistema aéreo no Brasil atual. In: Anais do 3 Simpósio Nacional de Geografia Urbana. Rio de Janeiro, 1993.

CORREAA, Roberto Lobato. et al. O sistema urbano brasileiro: uma análise através dos fluxos aéreos de passageiros In: Revista Brasileira de Geografia. Rio de Janeiro, 39 (3), 1977.

CORRÊA, Roberto Lobato. Interações Espaciais. In: CASTRO, I; G. P. C; CORRÊA, R. L. (Org). Explorações geográficas: percursos no fim do século. Rio de Janeiro: Bertrand Brasil, 1997. p. 279-318.

CORREAA, Roberto Lobato. Construindo o conceito de cidade média. In: In: SPOSITO, M. E. B. (Org). Cidades Médias: espaços em transição. Presidente Prudente/SP: Expressão Popular, 2007, p. 23-33.

CORRÊA, Roberto Lobato. Redes geográficas e teoria dos grafos. Textos LAGET, n. 1. Rio de Janeiro: UFRJ, 1999. (Série Pesquisa e Ensino). 
COUTINHO, Luciano. A terceira revolução industrial e tecnológica: As grandes tendências de mudança. In: Revista Economia e Sociedade. Campinas/SP: UNICAMP, n.1, 1992, p. 68-87.

COUTINHO, Luciano; FERRAZ, João Carlos. Estudo da competitividade da indústria brasileira. Campinas, SP: Papirus. Editora Unicamp, 1994.

DERRUAU, Max. Geografia Humana II. Lisboa: Editorial Presença, 1982.

DIAS, Leila. C. Os sentidos da rede: nota para discussão. In: DIAS, L. C; SILVEIRA, R. L. L. (Orgs). Redes, sociedades e territórios. Rio Grande do Sul: EDUNISC, 2005, p. 1128.

ESPÍRITO SANTO JR., Respício A. Integração regional e nacional para quê? O descaso com o transporte aéreo regional no Brasil. In: Revista Turismo em Números. Rio de Janeiro, n. 56, Ago-Set, 2006, p. 1-5.

ESTADO DE SÃO PAULO. Departamento Aeroviário do Estado de São Paulo. Revista Aeroportos do DAESP. São Paulo, 2006.

EXAME - Melhores e maiores. As 500 maiores empresas do Brasil. São Paulo: Abril, 2008.

FIANI, Ronaldo. Teoria dos custos de transação. In: KUPFER, D; HASENCLEVER, L. (Orgs.). Economia Industrial: fundamentos teóricos e práticas no Brasil. São Paulo: Campos, 2002, p. 267-286.

FOUQUET, Harro. Considerações sobre a Infraestrutura aeroportuária de São Paulo. [Trabalho encomendado ao autor]. São Paulo, 2007.

FOUQUET, Harro. Arquivo Histórico da Aviação Comercial Brasileira. [Entrevista realizada no dia 11/03/2008, das 14 h às 17 h e no dia 25/07/2008, das 13 h15 às $16 \mathrm{~h} 45$, ambas na cidade de São Paulo].

FRIEDMAN, Thomas L. O mundo é plano: uma breve história do século XXI. Rio de Janeiro: Objetiva, 2005.

FURTADO, Celso. Dialética do desenvolvimento. Rio de Janeiro: Fundo de Cultura, 1964.

GALLO, Fabrício. O papel do transporte aéreo na integração do território brasileiro. Dissertação (Mestrado em Geografia). Universidade de Estadual de Campinas/SP. Instituto de Geociências, 2006.

GANDRA, Mauro. A questão do transporte aéreo. In: BARAT, J. (Org). Logística e transporte no processo de globalização: oportunidades para o Brasil. Editora Unesp. São Paulo, 2007.

GARÓFALO, Gilson Lima. O mercado brasileiro de transporte aéreo regional. LivreDocência. Tese (Livre-Docência em Economia). São Paulo: IPE/USP, 1982.

GOL LINHAS AÉREAS INTELIGENTES. Relatório Anual. 2005, 2006, 2007, 2008.

GONÇALVES, Reinaldo. O nó econômico. Rio de Janeiro: Record, 2003. 
GUTHS, Marisa Larsen. A ação política do empresariado industrial catarinense: o caso da Fiesc. In: V Workshop Empresa, Empresários e Sociedade. Rio Grande do Sul, 2006.

HAESBAERT, Rogério. Globalização e fragmentação no mundo contemporâneo. In: HAESBAERT, R. (Org.). Globalização e fragmentação no mundo contemporâneo. Niterói/RJ: EdUFF, 1998.

HARVEY, David. A condição pós-moderna. 2a ed. São Paulo: Loyola, 1992.

HARVEY, David. A produção capitalista do espaço. $2^{\text {a }}$ ed. São Paulo: Annablume, 2006.

HASENCLEVER, Lia; Patrícia Moura Ferreira. Estrutura de mercado e inovação. In: KUPFER, D; HASENCLEVER, L. (Orgs.). Economia Industrial: fundamentos teóricos e práticas no Brasil. São Paulo: Campos, 2002, p. 129-147.

JESUS, Claudiana Guedes de. Desregulamentação e trabalho na aviação comercial brasileira (1990- 2002) Dissertação (Mestrado em Geografia). Campinas/SP: IG/Unicamp, 2005.

JOÃO, Belmiro do Nascimento. Das competências essenciais às estratégias baseadas no conhecimento. In: Revista Organização em Contexto. São Paulo. Ano 1, n. 1, jun, 2005.

KUPFER, David. Padrões de Concorrência e Competitividade, 2002. Disponível em: http://www.ie.ufrj.br/gic/pdfs/1992-2_Kupfer.pdf.

KUPFER, David. Uma abordagem neo-schumpeteriana da competitividade. In: Ensaios FEE. Porto Alegre/RS. v. 17, n. 1, 1996.

KUPFER, David; HASENCLEVER, Lia. (Orgs.) Economia Industrial: fundamentos teóricos e práticas no Brasil. São Paulo: Campos, 2002.

LAMOSO, Lisandra Pereira. A infraestrutura como elemento organizador do território. In: SILVEIRA, Márcio Rogério; LAMOSO, L. P; MOURÃO, P. F. C. Questões nacionais e regionais do território brasileiro. São Paulo: Expressão Popular, 2009, p. 43-62.

LENCIONI, Sandra. Cisão territorial da indústria e integração regional no Estado de São Paulo. In: BRANDÃO, C. A; GALVÃO, A. C; GONÇALVES, M. F. Regiões e cidades, cidades nas regiões. $O$ desafio urbano-regional. São Paulo: Editora UNESP, 2003.

LENCIONI, Sandra. Reestruturação urbano-industrial no Estado de São Paulo: a região da metrópole desconcentrada. Espaço \& Debates. São Paulo: NERU, n.38, 1994, p.54-61.

LENINE, Vladimir Ilich. Obras Escolhidas. 2.ed. São Paulo: Alfa Omega, 1980

LÉVY, Jacques. Os novos espaços da mobilidade. HAESBAERT, Rogério (Trad.). In: Revista GEOgraphia. Rio de Janeiro. Ano III. n. 6, Jul-Dez 2001.

LIMONAD, E. Urbanização e organização do espaço na era dos fluxos. In: BECKER, Bertha K; SANTOS, M. (Org). Território, territórios: ensaios sobre o ordenamento territorial. Rio de Janeiro: DP\&A, 2002.

LOSEKANN, Luciano; GUTIERREZ, Margarida. Diferenciação de produtos. In: KUPFER, D; HASENCLEVER, L. (Orgs.). Economia Industrial: fundamentos teóricos e práticas no Brasil. São Paulo: Campos, 2002, p. 91-108. 
LUXEMBURGO. Rosa. A acumulação do capital: estudo sobre a interpretação econômica do imperialismo. Rio de Janeiro: Zahar Editores, 1976.

MARQUES, Renato César. $O$ aeroporto e os fluxos aéreos no contexto da formação do espaço urbano regional: o caso de Maringá-PR. Dissertação (Mestrado em Geografia). Universidade Estadual de Maringá/PR, 2005.

MARX, Karl. Crítica da Economia Política. O processo de circulação do capital. Livro Segundo. SANT’ANNA Reginaldo (Trad.) Rio de Janeiro: Civilização Brasileira, 1970.

MATTOS, Paulo Todescan Lessa. A formação do Estado regulador. In: Novos Estudos. São Paulo, 2006, p. 139-156.

MELLO, Luis Martins de. Modelos tradicionais de concorrência. In: KUPFER, D; HASENCLEVER, L. (Orgs.). Economia Industrial: fundamentos teóricos e práticas no Brasil. São Paulo: Campos, 2002.

MINADEO, R; RAPHAEL, D. A; CUNHA, J. L. T. A Trajetória da TAM. In: XII Encontro da Associação Portuguesa de História Económica e Social. Portugal, 2003.

MONTEIRO, Cristiano Fonseca. A dinâmica política das reformas para o mercado na aviação comercial brasileira (1990-2002). Tese (Doutorado em Sociologia) Rio de Janeiro: UFRJ/IFCS/PPGSA, 2004.

MONTEIRO, Cristiano Fonseca. A Varig e o Brasil entre o desenvolvimento acional e a competitividade global. In: Civitas Revista de Ciências Sociais. Porto Alegre/RS, v. 7, n. 1, jan-jul, 2007, p. 35-58.

MOURÃO, Paulo Fernando Cirino. Reestruturação produtiva e industrialização do oeste paulista. In: SILVEIRA, M. R; LAMOSO, L. P; MOURÃO, P. F. C. Questões Nacionais e Regionais do Território Brasileiro. São Paulo: Expressão Popular, 2009, p. 197-218.

NEGRI, Jarbas. As políticas de descentralização industrial e o processo de interiorização em São Paulo. In: TARTAGLIA, J. C; OLIVEIRA, O. L de. Modernização e desenvolvimento no interior de São Paulo. São Paulo: Ed. UNESP, 1988, p. 11-37.

OLIVEIRA, Luis Guilherme de. A cadeia de produção aeronáutica no Brasil: uma análise sobre os fornecedores da Embraer. Tese (Doutorado em Política Científica e Tecnológica) Instituto de Geociências Unicamp. Campinas/SP, 2005.

OLIVEIRA, Alessandro Vinícius Marques de. A experiência brasileira na desregulamentação do transporte aéreo: um balanço e propositura de diretrizes para novas políticas. São José dos Campos/SP: SEAE/MF Documento de Trabalho n. 45, 2007.

OLIVEIRA, Alessandro Vinícius Marques de; SALGADO, Lucia Helena. Constituição do marco regulatório para o mercado brasileiro de aviação regional. NECTAR/ABETAR. São José dos Campos/SP, 2008.

OLIVEIRA, Alessandro Vinícius Marques de. Transporte aéreo: economia e políticas públicas. São Paulo: Pezco, 2009.

OWEN, Wilfred. Estratégia para os transportes. HASTINGS, David H. (Trad.). São Paulo: Pioneira, 1975. 
PATERSON, J. H. Terra, trabalho e recursos: uma introdução à Geografia econômica. Rio de Janeiro, Zahar, 1975.

PÊGO, Bolívar Filho. Setor aéreo e as empresas brasileiras: situação atual e perspectivas. In: Boletim de Conjuntura IPEA (Notas Técnicas). São Paulo, Out-Nov, 2002, p. 73-78.

PEREIRA, Mirlei Fachini Vicente. Redes e territorialidade da indústria aeronáutica brasileira: a Embraer S.A. e suas estratégias de uso do território. In: Revista Geografia. Rio Claro, v. 29, n. 1, jan/abr, 2004, p. 39-54.

PERROUX, François. A economia do século XX. Paris: Morais Editora, 1969.

PINI, Giuseppe. La Géographie des Transports. In: BAILLY, A. S. Les concepts de la géographie humaine. Masson: Paris Milan Barcelone, 1995, p. 139-144.

PIZZINATTO, Nadia Kassouf et al. Marketing de Convergência: Mudanças no Transporte Aéreo Brasileiro. In: Anais do II Seminário de Gestão de Negócios. Curitiba - PR : FAE, 2005, p. 1-20.

POCHMANN, Márcio. Reestruturação Produtiva. Perspectivas de desenvolvimento local com inclusão social. Petrópolis/RJ: Ed. Vozes, 2004.

PONS, Joana Maria Segui; BEY, Joana Maria Petrus. Geografia de redes y sistemas de transportes. Madrid, Espanha: Editorial Sintesis, 1991.

PONS, Joana Maria Segui; REYNES, Joana Maria Martinez. Geografía de los Transportes. Palma de Mallorca, Universitat de les Illes Balears. Madri: Ariel, 2004.

PORTER, Michael. Estratégia competitiva. Técnicas para análise de indústrias de concorrência. BRAGA, E. M. P. de (Trad.). Rio de Janeiro: Campus, 1986.

PORTER, Michael. Vantagem competitiva: criando e sustentando um desempenho superior. BRAGA, E. M. P. de (Trad.). Rio de Janeiro: Campus, 1989.

PORTER, Michael. Competição on Competition: estratégias competitivas essenciais. Rio de Janeiro: Campus, 1999.

PORTER, Michael. O que é estratégia? Grupo Técnico de Planejamento Estratégico. Pontifícia Universidade Católica do Rio Grande do Sul. Rio Grande Do Sul, 1996. Disponível em: http://www.mettodo.com.br/pdf/O\%20que\%20e\%20Estrategia.pdf> Acessado em 22/04/2009.

POSSAS, Mario L. Concorrência schumpeteriana. In: KUPFER, D; HASENCLEVER, L. (Orgs.). Economia Industrial: fundamentos teóricos e práticas no Brasil. São Paulo: Campos, 2002.

RAFFESTIN, Claude. Por uma Geografia do poder. São Paulo: Ática, 1993.

RAMOS, Teresa Mavignier de Andrade. Interações Espaciais no Estado de São Paulo: uma Análise Comparativa entre Dois Tipos de Redes. In: Anuário do Instituto de Geociências UFRJ. Rio de Janeiro. v 21, 1998.

RANGEL, Ignácio. O ciclo médio e o ciclo longo no Brasil. In: Ensaios FEE (Fundação de Economia e Estatística). Porto Alegre/RS, v.1, n. 1, 1983, p. 31-42. 
RANGEL, Ignácio. Obras Reunidas de Ignácio Rangel. Contraponto. Rio de Janeiro. v. 1 e 2, 2005.

RIBEIRÃO PRETO. Arquivo Histórico do Aeroporto de Ribeirão Preto, 2008.

RICARDO, David. Princípios de economia política e tributação. São Paulo: Nova Cultural, 1985.

RODRIGUES, Augusto Rodrigo. Aviação comercial no Brasil: a necessidade de um novo marco regulatório. In: Revista Res Pvblica, 5. ed. mar. 2004.

ROCHA, Aline. Uma análise da integração em rede: os transportes aéreos na Bahia. Dissertação (Mestrado em Geografia). Salvador, Bahia: PGG/IG /UFB, 2006.

SALGADO, Lucia Helena; GUIMARÃES, Eduardo Augusto. A regulação do mercado de aviação civil no Brasil. In: Notas Técnicas Instituto de Pesquisa Econômica Aplicada (IPEA). Rio de Janeiro, 2003.

SALGADO, Lucia Helena; MOTTA, R. S. (Orgs.). Marcos regulatórios no Brasil: o que foi feito e o que falta fazer. Rio de Janeiro: IPEA, 2005.

SALGADO, Lucia Helena. Caos aéreo e tragédia dos comuns: falhas de mercado e de Governo. IPEA. Rio de Janeiro, 2009.

SANDRONI, Paulo. Dicionário de economia do século XXI. Rio de Janeiro: Record, 2005.

SANTOS, Milton. A natureza do espaço. Técnica e Tempo. Razão e Emoção. São Paulo: Edusp, 2002.

SANTOS, Milton. Economia Espacial: críticas e alternativas. São Paulo: Edusp, 2003.

SANTOS, Milton; SILVEIRA, María Laura. O Brasil: território e sociedade no início do século XXI. $6^{\text {a }}$ ed. Rio de Janeiro - São Paulo: Record, 2004.

SANTOS, Milton. . Por uma outra globalização: do pensamento único à consciência universal. Rio de Janeiro: Record, 2005.

SÃO JOSÉ DO RIO PRETO. Conjuntura Econômica 2003. $18^{\mathrm{a}}$ ed. São José do Rio Preto: Secretaria Municipal de Planejamento. 2003. Disponível em: < www.riopreto.sp.gov.br > Acessado em 14/02/2009.

SILVA, Adyr da. Aeroportos e desenvolvimento. Instituto Histórico Cultural da Aeronáutica. Rio de Janeiro, 1991.

SILVEIRA, Márcio Rogério. Desenvolvimento econômico e transporte ferroviário: abordagem para o caso catarinense. Ourinhos/SP: Pereira Editora, 2006.

SILVEIRA, Márcio Rogério. Estradas de ferro do Brasil: das primeiras construções às Parcerias Público-Privadas. Rio de Janeiro: Interciência, 2007.

SILVEIRA, Márcio Rogério. As cinco revoluções e evoluções logísticas. In: SILVEIRA, M. R; LAMOSO, L. P; MOURÃO, P. F. C. Questões Nacionais e Regionais do Território Brasileiro. São Paulo: Expressão Popular, 2009, p. 13-42. 
SILVEIRA, Márcio Rogério. Logística, sistemas de movimento, fluxos econômicos e interações espaciais no território paulista: uma abordagem para a Geografia dos Transportes e Circulação. In: Scripta Nova. Revista Electrónica de Geografía y Ciencias sociales. Barcelona, V. XII, N. 283, 2009a. Disponível em: http://www.ub.es/geocrit/sn/sn-283.htm> Acessado em 21/03/2009.

SIMÕES, André Felipe. O transporte aéreo brasileiro no contexto de mudanças Climáticas globais: emissões de $\mathrm{CO}_{2}$ e alternativas de mitigação. Tese (Doutorado em Planejamento Energético). Rio de Janeiro. UFRJ, 2003.

SKIDMORE, Thomas. Brasil: de Getúlio Vargas a Castelo Branco, 1930 - 1964. Rio de Janeiro: Paz de Terra, 1982.

SMITH, Adam. A riqueza das nações: investigação sobre sua natureza e suas causas. São Paulo: Abril Cultural, 1983.

SOUTELINO, André Luis Dias. Desmistificando o sistema hub-and-spoke. Disponível em: http://www.oaviao.com.br/materias_comunidade/imagens.

SPOSITO, Eliseu Savério. Reestruturação produtiva e a reestruturação urbana no Estado de São Paulo. In: IX Colóquio Internacional de Geocrítica. Rio Grande do Sul, 2007.

SPOSITO, Eliseu Savério. Geografia e Filosofia. Contribuições para o ensino do pensamento geográfico. São Paulo: Editora Unesp, 2004.

SPOSITO, Eliseu Savério. Território, logística e mundialização do capital. In: SPOSITO, E. S. (Org.) Dinâmica econômica, poder e novas territorialidades. Presidente Prudente: UNESP/FCT/GAsPERR, 1999.

TAM LINHAS AÉREAS. Relatório Anual. 2007, 2008.

TAVARES, Márcia Prates. $O$ transporte aéreo doméstico e a lógica da desregulamentação. Documento de Trabalho SEAE. Brasília, nov. n. 4, 1999.

THÉRY, Hervé. O transporte aéreo no Brasil: asas da centralidade. In: Mercator Revista de Geografia da UFC. Fortaleza: [s.n.], ano 2, n. 3, 2003.

TOLMASQUIM, M. T. O Brasil e o ciclo de Kondratieff e Juglar segundo a obra de Ignácio Rangel. In: Revista de Economia Política. v 11, n 4 (44), out-dez, 1991, p. 27-38.

ULLMAN, Edward. Geography as spatial interaction. In: HURST, Michael Eliot (org.). Transportation Geography. Londres: Macgraw Hill, 1972, p. 29-39.

VELASCO, Sebastião C. Cruz. Globalização, democracia e ordem internacional. Ensaios de teoria e história. Editora UNESP, 2004.

VIEIRA, Guilherme Bergmann. Borges. Transporte Internacional de Cargas. $2^{\mathrm{a}}$ ed. São Paulo: Aduaneiras, 2003.

\section{SITES CONSULTADOS:}

www.abeatar.com.br 
www.anac.gov.br

www.aviacaobrasil.com.br

www.bndes.gov.br

www.daesp.sp.gov.br

www.estadao.com.br

www.ibge.gov.br

www.infraero.gov.br

www.ipea.gov.br

www.revistaflap.com.br

www.seade.gov.br

www.snea.com.br

www.tam.com.br

www.voegol.com.br

www.voepantanal.com.br

www.voepassaredo.com 
ANEXOS 


\section{A. Entrevista no Departamento Aeroviário do Estado de São Paulo.}

1. Qual o critério utilizado na realização da distribuição de empresas e rotas aéreas no Estado de São Paulo?

2. Nesse contexto de gestão, controle, seguridade entre mais fatores, qual a função do DAESP como órgão submetido à hierarquização do transporte aéreo e as ações das empresas aéreas no mercado?

3. O Plano Aeroviário Nacional tem função de direcionar o transporte aéreo nos Estados brasileiros. Como funciona e qual sua aplicabilidade no Estado de São Paulo?

4. Como o DAESP avalia as condições de infraestrutura dos aeroportos do interior do Estado de São Paulo?

5. Existe um tributo para detentores de avião?

6. No cenário regional, o DAESP vê um crescimento de empresas pequenas, tais como Air Minas, Pantanal, Passaredo etc.?

7. O Estado tem um sistema de linhas bem articulado ou isso varia de acordo com a demanda e a concorrência que se estabelece entre as empresas nas cidades?

8. Dentre a hierarquia de aeroportos do interior que possuem autorização para operar linhas regulares, isto é, Araçatuba, Bauru/Arealva, Marília, Presidente Prudente, Ribeirão Preto e São José do Rio Preto, qual o de maior expressividade para o Estado de São Paulo em relação à movimentação de passageiros?

\section{B. Entrevista com o Sr. Harro Fouquet.}

1. Como era o cenário da aviação regional no Estado de São Paulo na década de 1940 ?

2. Como era a relação do Governo com as empresas aéreas?

3. No início do processo de desenvolvimento do transporte aéreo no Brasil, o setor era explorado pela iniciativa privada estrangeira. Por que esse processo não teve continuidade e, posteriormente, a exploração passou para as empresas privadas brasileiras?

4. Qual a análise histórica do setor aéreo brasileiro, considerando suas fases de ascensão e desprestígio frente a outros modais?

5. Pode-se considerar que o SITAR foi uma estratégia do Governo na melhoria no transporte aéreo regional?

6. A concorrência com o modal rodoviário é propensa a qual setor?

7. A respeito da intermodalidade, incluindo, no caso, o modal aéreo, a questão das exportações brasileiras serem comodities, ou seja, produto de baixo valor agregado existe, 
portanto, um empecilho no desenvolvimento do transporte aéreo em participar da intermodalidade?

8. Qual sua visão sobre a infraestrutura aeroportuária do Estado de São Paulo?

9. Qual foi o papel do DAC no desenvolvimento do transporte aéreo brasileiro? Foi um papel ideológico?

10. O papel exercido pelo DAESP (Departamento Aeroviário do Estado de São Paulo) tem correspondido com suas atribuições junto aos órgãos de gestão do transporte aéreo brasileiro?

11. Sobre atuação das empresas aéreas, sobretudo a Gol e a TAM, que são empresas de âmbito nacional, qual sua visão sobre estas empresas hoje, sobre as estratégias de mercado que visam prioritariamente à concorrência indiscriminada, especialmente com empresas de âmbito regional?

12. Qual a expectativa sobre o futuro das empresas aéreas regionais do Estado de São Paulo, mediante a diminuição e a sazonalidade das empresas aéreas em cidades do interior paulista?

13. Como surgem as empresas Gol e TAM, qual o momento favorável que proporcionou o desenvolvimento dessas empresas e como elas estão hoje no cenário da aviação?

14. A década 1980 sofreu um processo de desregulamentação setorial ocorrida no Brasil. A crise ocorrida na década de 1990 foi resultado desse processo de desregulamentação?

\section{Entrevista no Aeroporto de Araçatuba.}

1.Como é o funcionamento do Aeroporto de Araçatuba e como é feito o controle no aeroporto?

2. Esses voos de outras empresas são voos regulares?

3. Quais as empresas aéreas que operam voos não regulares no Aeroporto de Araçatuba?

4. Quais as empresas que efetivamente realizam voos regulares em Araçatuba?

5. Por que um aeroporto que possui uma distância considerável da capital e poderia ter uma conexão mais concentrada de voos só tem uma empresa operando voos?

6. Qual a alegação das empresas quando encerraram suas atividades no Aeroporto de Araçatuba?

7. Por quê? A Pantanal não tem estrutura para a aviação comercial no Estado de São Paulo?

8. A demanda pelo transporte aéreo no Aeroporto é originária de Araçatuba ou passageiros de outros centros urbanos maiores procuram o aeroporto? 
9. Quais as condições gerais de infraestrutura do Aeroporto de Araçatuba?

10. Essas melhorias em infraestrutura podem contribuir para o aumento da demanda no Aeroporto de Araçatuba?

11. A localização de Araçatuba, que é próxima a dois aeroportos regionais importantes, como São José do Rio Preto e Presidente Prudente, dificulta o desenvolvimento do aeroporto? Como é a concorrência com esses aeroportos?

12. Quanto aos investimentos, quais são e quanto de investimentos o Aeroporto recebe do Estado por ano?

13. Os investimentos que o Aeroporto recebe são suficientes para manter a qualidade e quantidade de infraestrutura necessária?

14. O Aeroporto de Araçatuba utiliza o PAESP?

15. O PAESP contribui para a organização geral dos aeroportos?

16. Qual o papel do DAESP para o funcionamento dos Aeroportos no interior do Estado de São Paulo? Sua execução como órgão gestor tem contribuído para o transporte aéreo regional no Estado?

17. Sobre a concessão de aeroportos, há alguma previsão, estudo ou proposta de concessão ou privatização do Aeroporto de Araçatuba? Isso é viável?

18. Os aeroportos do interior de São Paulo são deficitários?

19. Isso se deve à falta de investimentos do Governo ou à demanda pelo modal aéreo?

20. O Aeroporto de Araçatuba recebe investimentos do PROFAA. O PROFAA prioriza os aeroportos com voos regulares?

21. Sobre o aumento de investimentos em aeroportos do interior, como forma de descongestionar os aeroportos de São Paulo e, consequentemente, dinamizar os aeroportos regionais, é uma alternativa viável?

22. A nova empresa aérea AZUL Linhas Aéreas, que entra no mercado em 2009, tem uma proposta de interligar centros regionais sem necessariamente passar por São Paulo. Esta é uma iniciativa que pode funcionar?

23. Quais as perspectivas para a aviação comercial regional no Estado de São Paulo e na cidade de Araçatuba?

\section{Entrevista no Aeroporto de Bauru/Arealva.}

1.Como é o funcionamento do Aeroporto de Bauru/Arealva? Como é realizado o controle de aeronaves (pousos e decolagens) do Aeroporto? 
2. Porque o Aeroporto de Bauru passou as operações de voos regulares para o Aeroporto de Bauru/Arealva?

3. Como é o funcionamento do antigo Aeroporto de Bauru?

4. No Aeroporto de Bauru/Arealva, há voos de fretamento?

5. A mudança para o Aeroporto de Bauru/Arealva trouxe melhorias, como o aumento da demanda?

6. Por que as empresas Oceanair Linhas Aéreas e a Air Minas pararam de operar no Aeroporto de Bauru/Arealva?

7. A demanda pelo transporte aéreo no Aeroporto é originária de Bauru? Se não, qual a origem?

8. A localização de Bauru é estratégica no Estado de São Paulo, e isso é fator que apresenta uma maior demanda e por que não há um maior número de empresas operando voos, já que a localização pode favorecer conexões com outros centros urbanos?

9. Como é a concorrência com os aeroportos próximos, como Presidente Prudente e Marília?

10. Quais as condições gerais de infraestrutura do Aeroporto de Bauru/Arealva?

11. Quanto aos investimentos, quais são e quanto de investimentos o Aeroporto recebe do Estado por ano?

12. Os investimentos são suficientes para manter a qualidade e quantidade das condições de infraestrutura no Aeroporto? Se não, por quê?

13. O Aeroporto de Bauru/Arealva utiliza o PAESP?

14. Há expectativas da AZUL Linhas Aéreas operar em Bauru/Arealva ou de outras empresas operarem?

15. Se a AZUL Linhas Aéreas viesse operar no Aeroporto de Bauru/Arealva, a mesma teria um retorno financeiro compensatório?

16. Sobre a concessão ou privatização de aeroportos, há alguma previsão para Bauru/Arealva? Essa proposta é viável?

17. Qual o papel do DAESP para o funcionamento dos Aeroportos no interior do Estado de São Paulo? Sua execução como órgão gestor tem contribuído para o transporte aéreo regional no Estado?

18. O Aeroporto de Bauru/Arealva recebe ou já recebeu investimentos do PROFAA?

19. Quais as perspectivas para a aviação comercial regional no Estado de São Paulo e na cidade de Bauru/Arealva? 


\section{E. Entrevista no Aeroporto de Marília.}

1.Como é o funcionamento do Aeroporto de Marília?

2.Quais as empresas que efetivamente realizam voos regulares em Marília?

3. A demanda pelo transporte aéreo no Aeroporto é de origem de Marília? Se não, qual a origem?

4. Quais as condições gerais de infraestrutura do Aeroporto?

5.Quanto aos investimentos, quais são e quanto de investimentos o Aeroporto recebe do Estado por ano?

6. Os investimentos são suficientes para manter a qualidade e quantidade das condições de infraestrutura no Aeroporto? Se não, por quê?

7. Quais os reais motivos para o fechamento do Aeroporto de Marília?

8. A demanda pelo modal aéreo é suficiente para o não fechamento do Aeroporto de Marília?

9. O Aeroporto de Marília utiliza o PAESP?

10. Como é realizado o controle de aeronaves (pousos e decolagens) do Aeroporto?

11. Quantos voos efetivamente partem e chegam ao Aeroporto por dia?

12. Qual o papel do DAESP para o funcionamento dos Aeroportos no interior do Estado de São Paulo? Sua execução como órgão gestor tem contribuído para o transporte aéreo regional no Estado?

13. Quais as perspectivas para a aviação comercial regional no Estado de São Paulo e na cidade de Marília?

\section{F. Entrevista no Aeroporto de Presidente Prudente.}

1. Como é o funcionamento do Aeroporto de Presidente Prudente?

2. Então, há investimentos da federal da INFRAERO no Aeroporto de Presidente Prudente?

3. Quais as empresas que efetivamente realizam voos regulares em Presidente Prudente?

4. O que é mais importante para a aviação regional em termos econômicos, o transporte de passageiros ou de carga?

5. O Aeroporto de Presidente Prudente transporta que tipo de carga?

6. A demanda pelo transporte aéreo no Aeroporto é originária de Presidente Prudente?

7. Quais as condições gerais de infraestrutura do Aeroporto de Presidente Prudente?

8. Quanto aos investimentos, quais são e quanto de investimentos o Aeroporto recebe do Estado por ano? 
9. O Aeroporto de Presidente Prudente utiliza o PAESP?

10. O PAESP contribui para a organização geral dos aeroportos?

11. Os investimentos do PROFAA são destinados também para aeroportos que não operam voos regulares. Não é mais interessante para o Governo investir em aeroportos regulares, devido à maior rentabilidade e à possibilidade de maior integração territorial?

12. O Estado de São Paulo possui 31 aeroportos e apenas 6 realizam voos regulares. Por que esse número de aeroportos regulares não é maior?

13. Quando se compara os valores cobrados nas tarifas dos modais aéreo e rodoviário, percebe-se uma difrença muito grande. A diminuição do valor das passagens aéreas pode aumentar a demanda e isso contribuiria para o desenvolvimento da aviação comercial regional. Isso é possível?

14. Como é realizado o controle de aeronaves (pousos e decolagens) do Aeroporto?

15. Qual o papel do DAESP para o funcionamento dos Aeroportos no interior do Estado de São Paulo? Sua execução como órgão gestor tem contribuído para o transporte aéreo regional no Estado?

16. Quais as perspectivas para a aviação comercial regional no Estado de São Paulo e na cidade de Presidente Prudente?

17. Há perspectiva de alguma outra empresa aérea realizar voos regulares em Presidente Prudente?

18. Há voos da Pantanal e da Gol para São Paulo. Como fica a concorrência entre as empresa?

\section{G. Entrevista no Aeroporto de Ribeirão Preto.}

1. Quais as características gerais que fazem com que o Aeroporto de Ribeirão Preto seja o principal aeroporto regional do interior do Estado de São Paulo?

2. Nesse caso, porque o aeroporto de Araçatuba, que é o mais distante dos grandes centros econômicos, não apresenta a mesma dinâmica para o transporte aéreo como o aeroporto de Ribeirão Preto?

3. Como é o funcionamento do Aeroporto de Ribeirão Preto e como é feito o controle de pousos e decolagens no aeroporto?

4. A demanda pelo transporte aéreo no Aeroporto é originária de Ribeirão Preto?

5. São José do Rio Preto está localizada próximo à cidade de Ribeirão Preto e possui um importante aeroporto regional. Como é a concorrência com São José do Rio Preto?

6. Quais as empresas que efetivamente realizam voos regulares em Ribeirão Preto? 
7. Como é a malha de voos das empresas aéreas no Aeroporto de Ribeirão Preto e quais as aeronaves utilizadas para os voos regionais? Elas são compatíveis para a aviação regional?

8. Como é a concorrência entre as empresas aéreas que operam voos no aeroporto de Ribeirão Preto?

9. A novidade para a aviação comercial regional é a nova empresa que começa a atuar no mercado em 2009, a AZUL Linhas Aéreas. Essa empresa traz a proposta de operar voos regionais, sem passar pela metrópole São Paulo. Essa proposta é viável? Há demanda para esse mercado?

10. O que se percebe é que existem duas grandes empresas que controlam o mercado aéreo hoje, a TAM e a Gol. Em Presidente Prudente, temos a Gol e Pantanal realizando voos para São Paulo, mas a Gol atrai os passageiros e a Pantanal fica com uma parcela menor. Como é essa relação entre as empresas?

11. Nas cidades da pesquisa, não encontramos as empresas TAM e Gol concorrendo nas mesmas rotas. Há uma combinação entre essas empresas para manter o duopólio da aviação comercial?

12. Quando se fala em concorrência desleal, temos que a TAM e a Gol promovem esse tipo de concorrência para com as empresas de pequeno porte, ou seja, aquelas que operam voos regionais, o que tem provocado a falência e a fusão de pequenas empresas aéreas. Como é planejada essa situação no mercado aéreo?

13. Quais as condições gerais de infraestrutura do Aeroporto de Ribeirão Preto?

14. Quanto aos investimentos, quais são e quanto de investimentos o Aeroporto recebe do Estado por ano?

15. E o PROFAA, como ele funciona e quais os investimentos obtidos?

16. O PROFAA investe em todos os aeroportos da Federação, independentemente se os mesmos operam voos regulares ou não-regulares. Para o Governo, é mais interessante investir em aeroportos com voos regulares ou em aeroportos gerais?

17. Nesta pesquisa, realizamos um levantamento histórico de políticas de desenvolvimento do setor de transporte aéreo no Brasil. Observamos que o SITAR constituiu uma importante ferramenta de regulamentação do sistema aeroviário pelo Governo. Hoje, não existem mais esses tipos de propostas e de políticas de cunho regulamentário. Por quê? Não é viável para o Governo regulamentar o setor de transporte aéreo no Brasil?

18. A concessão ou a privatização dos aeroportos é viável?

19. Esse projeto do Governo Federal é uma Parceria Pública Privada (PPP) ou é um programa de concessão? 
20. Isso não é contraditório? Pois o Governo é, ao mesmo tempo, controlador e fiscalizador de um segmento em que é também garantidor financeiro de tal empreendimento.

21. Há interesse da iniciativa privada em fazer parcerias com o Governo nos Aeroportos que apresentam baixa rentabilidade, baixo nível de fluxos e que não possuem demanda concentrada?

22. O Aeroporto de Ribeirão Preto utiliza o PAESP?

23. Os investimentos são suficientes para manter a qualidade e quantidade das condições de infraestrutura no Aeroporto? Como são administrados os recursos disponibilizados?

24. Qual o papel do DAESP para o funcionamento dos Aeroportos no interior do Estado de São Paulo? Sua execução como órgão gestor tem contribuído para o transporte aéreo regional no Estado?

25. Quais as perspectivas para a aviação comercial regional no Estado de São Paulo e na cidade de Ribeirão Preto?

26. Existe alguma expectativa de que a AZUL entrará para operar no mercado de Ribeirão Preto?

\section{H. Entrevista no Aeroporto de São José do Rio Preto.}

1. Como é o funcionamento do Aeroporto de Presidente Prudente e quais a empresas que operam no Aeroporto de São José do Rio Preto?

2. A demanda pelo transporte aéreo no Aeroporto é originária de São José do Rio Preto?

3. Ribeirão Preto está localizado próximo a São José do Rio Preto a e possui um importante aeroporto regional. Como é a concorrência com Ribeirão Preto?

4. Quais as condições gerais de infraestrutura do Aeroporto de São José do Rio Preto?

5. Os investimentos que o Aeroporto de São José do Rio Preto recebeu foram suficientes para manter a qualidade e quantidade de infraestrutura necessária?

6. O Aeroporto de São José do Rio Preto utiliza o PAESP?

7. O PAESP é um plano do Governo Estadual que trabalha c projeção de 25 anos. Isso não atrapalha o desenvolvimento dos aeroportos? O PAESP contribui para a organização geral dos aeroportos?

8. Nesse sentido de planejamento, segurança, proteção, como é feito o controle para acidentes no aeroporto?

9. Qual o papel do DAESP para o funcionamento dos Aeroportos no interior do Estado de São Paulo? Sua execução como órgão gestor tem contribuído para o transporte aéreo regional no Estado? 
10. Quanto ao PROFAA, o Aeroporto recebeu investimentos do programa?

11. Sobre a concessão de aeroportos, tem alguma previsão, estudo ou proposta de concessão ou privatização do Aeroporto de São José do Rio Preto? Isso é viável?

12. Os investimentos do Governo priorizam os aeroportos que possuem voos regulares?

13. Quais as perspectivas para a aviação comercial regional no Estado de São Paulo e na cidade de São José do Rio Preto?

14. Qual a expectativa para entrada no mercado da nova empresa aérea, a AZUL Linhas Aéreas?

15. Isso é em decorrência da ausência de concorrência entre as empresas?

16. A Gol encerrou suas operações em São José do Rio Preto e passou suas operações para Presidente Prudente. Quando a Gol estava em São José do Rio Preto, a concorrência era maior e como funcionava?

17. Como é a concorrência entre a TAM e a Passaredo no Aeroporto de São José do Rio Preto?

18. Os modelos de aeronaves utilizados pela TAM no Aeroporto de São José do Rio Preto são adequados para a aviação regional comercial?

19. Sobre as concessões de aeroportos no Estado de São Paulo, o que tem de material sobre esse projeto e quais são as discussões sobre ele?

\section{Entrevista com a Empresa Gol Linhas Aéreas Inteligentes.}

1. Quais as características gerais da empresa? Abarcar elementos como origem, investimentos realizados, logística, controle acionário nacional ou estrangeiro etc.?

2. Quantos empregados possui a empresa? Há terceirizações? Se sim, em quais atividades?

3. Como se dá o planejamento de linhas, rotas, escalas e conexões pela empresa aérea Gol Linhas Aéreas Inteligentes?

4. Há projeto para expansão de linhas, rotas da empresa Gol Linhas Aéreas Inteligentes no Estado de São Paulo? Se sim, em quais locais e em quais aeroportos?

5. Quais os principais obstáculos ao fomento do transporte aéreo no Brasil e, em especial, no Estado de São Paulo?

6. Na sua concepção, as Parcerias Público-Privadas (PPPs) e, em especial, as concessões aeroportuárias são importantes para a expansão do transporte aéreo? As PPPs podem ser estendidas para os aeroportos do interior do Estado de São Paulo?

7. Há dados sobre investimentos, receitas, relatórios anuais de demonstrações financeiras etc., que podem ser disponibilizados para consulta? 
8. Qual a estrutura de equipamento da empresa Gol Linhas Aéreas Inteligentes (tipos e quantidade de aeronaves, equipamentos de aviação, de venda de passagens etc.)?

9. Em relação geográfica, qual o Estado em que a empresa Gol Linhas Aéreas Inteligentes obtém os maiores percentuais de lucratividade? Por quê?

10. A crise econômica atual tem atingido a empresa Gol Linhas Aéreas Inteligentes? De que forma? Quais as consequências dessa crise para a aviação comercial?

11- Qual a relação empresarial que a empresa Gol Linhas Aéreas Inteligentes tem com as demais empresas aéreas nacionais e internacionais?

12. Como é administrada a concorrência com a empresa TAM Linhas Aéreas? A Gol Linhas Aéreas Inteligentes tem estimativas e projetos de superação da concorrência com outras empresas?

13- Quais as vantagens competitivas que a empresa Gol Linhas Aéreas Inteligentes tem em relação às demais empresas do ramo?

14- A estratégia de low cost, low fare é a melhor alternativa de atração de demanda para a empresa? Por quê?

15. A atual empresa AZUL Linhas Aéreas Brasileiras é uma concorrente em potencial para a empresa Gol Linhas Aéreas Inteligentes? Por quê?

16. Quais os aeroportos superavitários do interior do Estado de São Paulo?

17- Ribeirão Preto pode se tornar um hub regional no Estado de São Paulo? Por quê?

18. Quais as perspectivas para a aviação regional comercial no Estado de São Paulo?

\section{J. Entrevista com a Empresa TAM Linhas Aéreas.}

1. Como se dá o planejamento de linhas, rotas, escalas e conexões pela empresa TAM Linhas Aéreas?

2. Há projeto para expansão de linhas, rotas da empresa TAM Linhas Aéreas no Estado de São Paulo? Se sim, em quais locais e em quais aeroportos?

3. Quais os principais obstáculos ao fomento do transporte aéreo regional?

4. Na sua concepção, as Parcerias Público-Privadas (PPPs) e, em especial, as concessões aeroportuárias são importantes para a expansão do transporte aéreo?

5. Há dados sobre investimentos, receitas, relatórios anuais de demonstrações financeiras etc., que podem ser disponibilizados para consulta?

6. Qual a relação empresarial que a empresa TAM Linhas Aéreas tem com as demais empresas aéreas nacionais e internacionais? 
7. Quais as vantagens competitivas que a empresa TAM Linhas Aéreas tem em relação às demais empresas do ramo?

8. A crise econômica atual tem atingido a empresa TAM Linhas Aéreas? De que forma? Quais as consequências dessa crise para a aviação comercial?

9. Como é administrada a concorrência com a empresa Gol Linhas Aéreas Inteligentes? A TAM Linhas Aéreas tem estimativas e projetos de superação da concorrência com outras empresas?

10. A atual empresa AZUL Linhas Aéreas Brasileiras é uma concorrente em potencial para a empresa TAM Linhas Aéreas? Por quê?

11. Ribeirão Preto pode se tornar um $h u b$ regional no Estado de São Paulo? Por quê?

12. Quais as perspectivas para a aviação comercial regional brasileira?

\section{Entrevista com a Empresa Passaredo Linhas Aéreas Inteligentes.}

1. Quais as características gerais da empresa? Abarcar elementos como origem, investimentos realizados, logística, controle acionário nacional ou estrangeiro etc.?

2. Como se dá o planejamento de linhas, rotas, escalas e conexões pela empresa aérea Passaredo Linhas Aéreas?

3. Há projeto para expansão de linhas, rotas da empresa Passaredo Linhas Aéreas no Estado de São Paulo? Se sim, em quais locais e em quais aeroportos?

4. Quais os principais obstáculos ao fomento do transporte aéreo regional e, em especial, no Estado de São Paulo?

5. Na sua concepção, as Parcerias Público-Privadas (PPPs) e, em especial, as concessões aeroportuárias são importantes para a expansão do transporte aéreo? As PPPs podem ser estendidas para os aeroportos do interior do Estado de São Paulo?

6. Há dados sobre investimentos, receitas, relatórios anuais de demonstrações financeiras etc., que podem ser disponibilizados para consulta?

7. Qual a relação empresarial da Passaredo Linhas Aéreas com as demais empresas aéreas nacionais?

8. Isso não favorece ainda mais o poderio das grandes empresas do mercado aéreo?

9. Até o ano de 2007, a Gol operava em Ribeirão Preto. A empresa encerrou suas atividades no principal aeroporto regional do Estado de São Paulo e passou a operar em Presidente Prudente, local onde a TAM não opera. Há acordos entre as grandes empresas no controle do mercado? 
10 Atualmente, as empresas aéreas têm investido em tecnologia, sobretudo na venda de passagens, chec in pela internet, parcelamento das passagens etc. Como a Passaredo lida com essas iniciativas?

11. Outra estratégia competitiva das empresas são os investimentos em publicidade e marketing. A empresa Passaredo investe nesse setor e quanto é destinado para ele?

12. A Passaredo é a única empresa regional no Estado de São Paulo que utiliza aeronaves Embraer. Por quê? Os modelos atendem bem a esse segmento?

13. Qual a estrutura de equipamento da empresa Passaredo Linhas Aéreas (tipos e quantidade de aeronaves)?

14. A crise econômica atual tem atingido a empresa Passaredo Linhas Aéreas? De que forma? Quais as consequências dessa crise para a aviação comercial?

15. Como é administrada a concorrência com a empresa TAM Linhas Aéreas? A Gol Linhas Aéreas Inteligentes tem estimativas e projetos de superação da concorrência com outras empresas?

16. A atual empresa AZUL Linhas Aéreas Brasileiras é uma concorrente em potencial para a empresa Trip Linhas Aéreas? Por quê?

17. Ribeirão Preto pode se tornar um $h u b$ regional no Estado de São Paulo? Por quê?

18. Sobre a ANAC. Para as empresas, qual a viabilidade dessa agência? Há regulamentação ou a agência só cumpre o papel de "complicador"?

19. Quais as perspectivas para o transporte aéreo regional no Estado de São Paulo? 